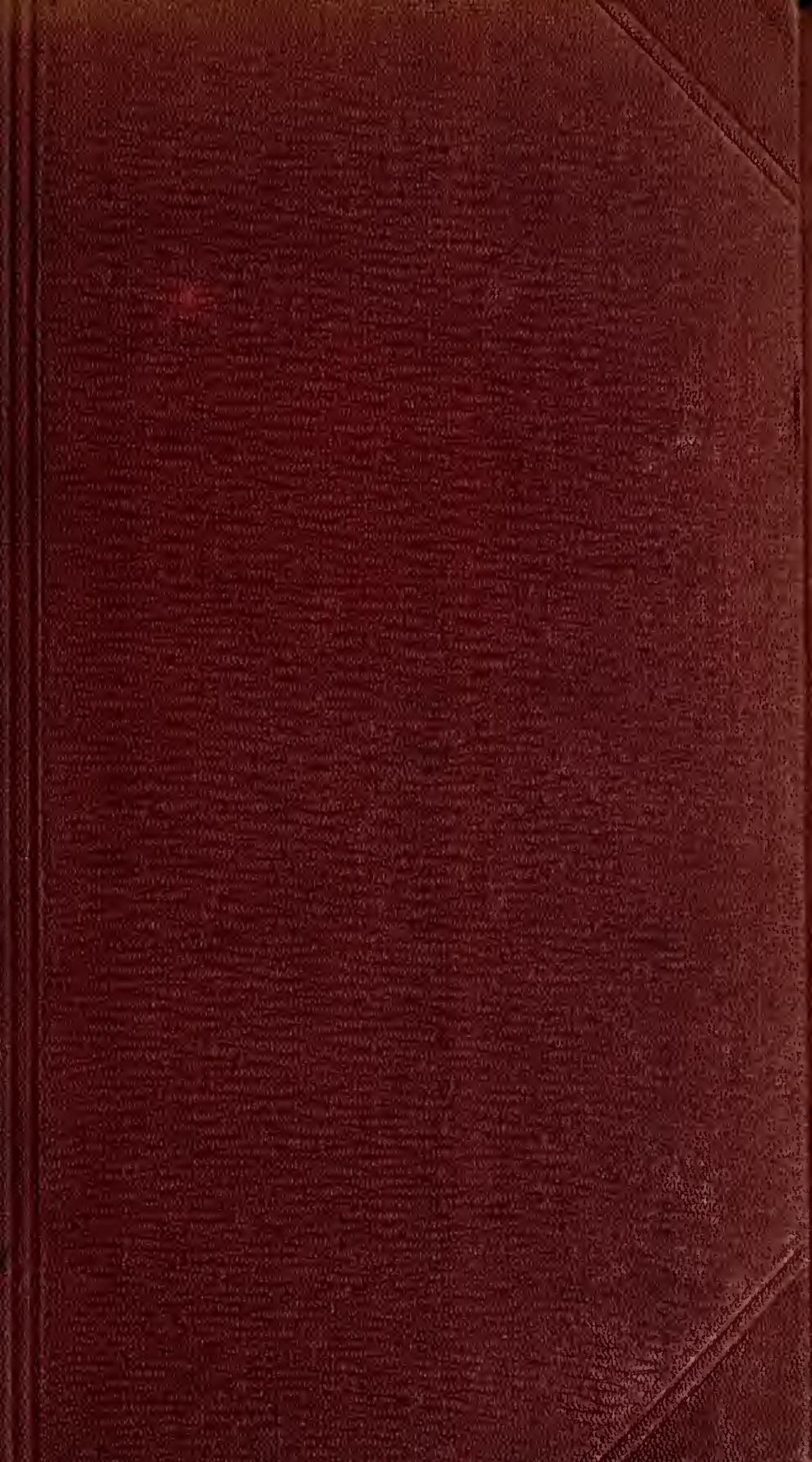




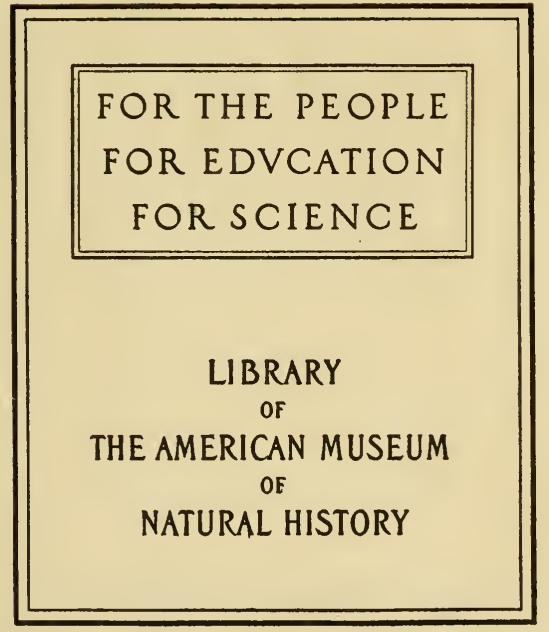






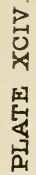

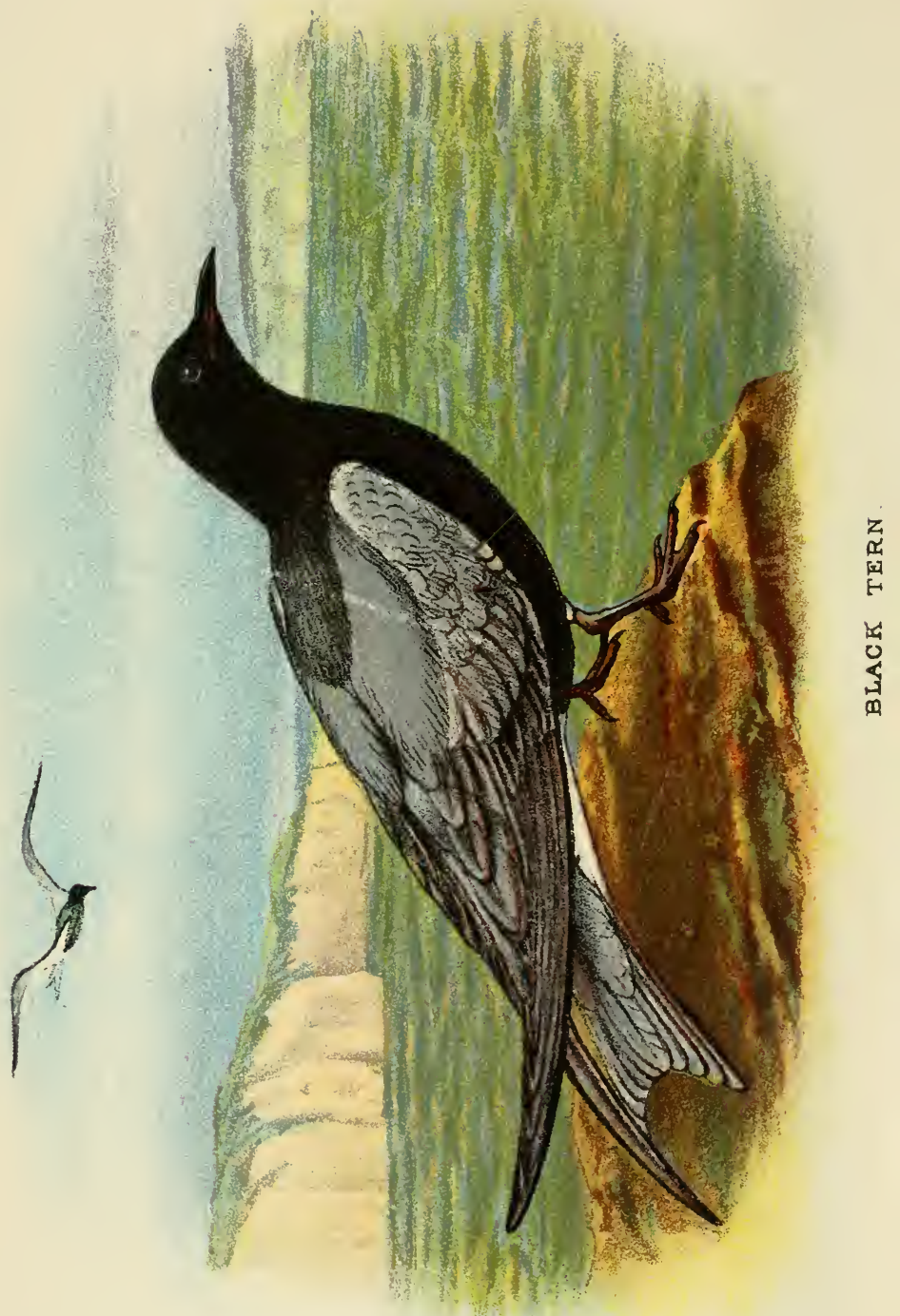




\title{
LLOYD'S NATURAL HISTORY
}

Edited by R. Bowdler Sharpe, LL.D., F.L.S., \&c.

\author{
A HAND-BOOK \\ TO THE \\ BIRDS \\ OF \\ GREAT BRITAIN.
}

BY

R. BOWDLER SHARPE, LL.D., ASSISTANT KEEPER, SUB-DEPARTMENT OF VERTEBRATA, ZOOLOGICAL DEPARTMENT, BRITISH MUSEUM.

VOL. IV.

LONDON:

EDWARD LLOYD, LIMITED,

I2, SALISBURY SQUARE, FLEET STREET. 
PRINTED BY

WYMAN AND SONS, LIMITED.

$$
59 \underset{\pi i \pi}{82}(42)
$$

$$
\begin{gathered}
14565 \\
\text { MAR } 291957
\end{gathered}
$$




\section{PREFACE.}

ON the conclusion of my "Handbook" I should like to say a few words, principally in reply to some friendly criticisms. The plentiful crop of works on British Birds, which springs up year by year and apparently flourishes, renders it almost an impossibility to write a book on the subject on altogether new lines, as the story of our native birds is being told by a hundred authors in a hundred different ways. Within the restricted limits allotted to me in the "Naturalist's Library," it was manifestly impossible to produce a monographic work, and therefore I chose the form of a 'Handbook,' a method which possesses its advantages and disadvantages. Such a work cannot be exhaustive, and I have therefore only tried to make it useful, and I offer a few remarks by way of an "Apologia."

Nomenclature.-The names adopted for the species have been much criticised. Much of this criticism has been prompted by pedantry, and a sort of hero-worship for the work of the ancients, more by a child-like ignorance of the principles of scientific nomenclature, and still more by a wilful and narrowminded intolerance of anything that seems to be "new." As a matter of fact, nothing in my system of nomenclature is "new," and any one who says so does but display his ignorance of recent ornithological literature. It is, however, encouraging to find that in the best-known popular journals, and even in the best scientific publications of this country, little fault has been found with the method of my "Handbook," but a general onslaught has been made upon the nomenclature I have adopted. To the reviews in the scientific journals I have scarcely any reply to make. The writers of the articles will be found adopting my nomenclature in the near future, and if 
not, why not? They will have to explain clearly their reasons for differing from me, and I have little fear as to their ultimate conversion.

To the ornithological students, and to the critics on the staffs of the popular daily and monthly journals who differ from me, I should like once more to explain my reasons for employing the names I do. I have not adopted the names given in the tenth edition of Linnæus "Systema Naturæ" ( $\left.175^{8}\right)$, but have preferred those of the twelfth edition ( $\mathrm{I}$ 766). Therein I follow the rules of the British Association. American and German ornithologists start their nomenclature from 1758 , because in this year Linnæus first promulgated a strictly binomial nomenclature. Good! But, after death, a man would surely wish to be judged by his most recent work, not by his earlier publications. Therefore, it seems to me most reasonable to adopt the nomenclature of the twelfth edition of the "Systema Naturæ," as being the last edition published by Linnæus himself, and containing his latest notions. In the eight years which elapsed since the publication of the tenth edition, Linnæus must have felt that his knowledge had gained somewhat, otherwise he would not have altered any of his work in his twelfth edition. Few critics have fallen foul of me on this score, and indeed the changes of nomenclature would be trifling, even if this adoption of the I 758 edition became universal, needless as it seems to me.

The chief point of offence laid to my door is rather the employment of an identical generic and specific name, and I find that all my explanations on the subject have failed to convince the "man in the street." I should like to explain myself once more, and I trust that the following example ( $E x$ uno disce omnes) may suffice to illustrate the principles of nomenclature that I champion.

I take it that no one, whether adopting the tenth or the twelfth edition of Linnæus' "Systema," will object to the prin- 
ciple that a Linnean specific name ought not to be altered, if the species to which it applies is beyond question.

Let us take a couple of familiar examples. The Blackbird I call Merula merula (Linn.). It is the Turdus merula of Iinnæus. Many ornithologists do not admit that the Blackbird is generically distinct from the Thrush (Turdus musicus), but for those who think otherwise, what is the generic name of the Blackbird to be? It is Merula of Leach, and therefore, if it is considered necessary to keep Merula distinct from Turdus, the Blackbird must be called Merula merula (Linn.). Or to take the genus Cinclus. The Black-bellied Dipper is the Sturnus cinclus of Linnæus. No one in these days would suggest that the Dippers are Starlings, and everyone adopts Bechstein's genus Cinclus for these birds. The result is that the Blackbellied Dipper must bear the name of Cinclus cinclus (Linn.) I see no sort of escape from this conclusion.

Then, again, there is often a difficulty in fixing the type of a Linnean genus, because modern research has much enlarged the scope of our knowledge of birds since i766. Thus the genus Turdus of Linnæus is the Family Turdide of our present Systems, and the genus Strix of Linnæus equals the Family Strigida or the Order Striges of the present day. The type of a Linnean genus can, therefore, be fixed only by "elimination." I will take the genus Strix as an example.

Twelve species of Strix were known to Linnæus and described by him in 1766 , divided into two sections-those with ear-tufts, and those without.

a. Auriculate ( $=$ Genus Asio, Briss. I 760).

Type of $B u b o$, Cuvier, I 8 I 7 .

Type of Scops, Savigny, isog.
I. bubo.

2. scandiaca $=$ No. 6 .

3. asio. Is also a $S c o p s$, like

4. otus.

5. scops.
[No. 5 . 


\section{b. Inauriculate ( $=$ Strix, Linn.).}

Type of Nyctea, Stephens, 1826 . 6. nyctea.

Type of Syrnium, Savigny, i800. 7. aluco.

8. flammea.

9. stridula $=$ No, 7 .

Type of Surnit, Dumeril, i $806 .\left\{\begin{array}{l}\text { 1 o. ulula } \\ \text { I I. funerea }\end{array}\right.$ Type of Glaucidium, Boie, 1826. I 2. passerina

Hence we see that, by the gradual elimination of the Linnean species, as one after another becomes fixed as the type of some genus or other, Strix olus, Linn., remains the type of the genus Asio, Briss., and Strix flammea is the sole survivor of the genus Strix as instituted by Linnæus, and becomes its type.

Besides this, Savigny, when he split up the Owls in 1809 , and made several new genera, restricted the Barn Owl for his genus Strix (ex Linn.), as he had every right to do.

Descriptions. - In the accounts of the different plumages of our British Birds, I have, in nearly every case, described actual specimens in the British Museum, and my descriptions throughout the work have been mostly original. Some of my critics have complained that these descriptions are unnecessarily long, especially in the case of foreign bird; which have occurred but a few times in Great Britain. To that I would reply, that no one knows what is going to happen, and these detailed descriptions may one day be found useful in determining foreign visitors to our shores; and secondly, by the many hundreds of earnest students, who may be unknown to fame, but who are nevertheless doing excellent work in many parts of the country, these descriptions are studied, as I have been informed by many of my correspondents. I have tried to condense into this "Handbook" only such descriptions of plumage as will be useful to students, to whom the large works, in which such details appear, are often inaccessible. In many instances I have 
copied the descriptions published by me in my volumes of the "Catalogue of Birds in the British Museum," when I found that I could not add any new information on the subject; and I have been guided by the excellent volumes recently published by Mr. Salvin, Count Salvadori, Mr. Howard Saunders, and Mr. Ogilvie Grant, while I am indebted to the writings of these gentlemen for important useful information, much of which has not been published in any previous popular work on British Birds.

Geographical Distribution and Habits.-In the treatment of this branch of the subject, it is impossible to be original, and the student will find little in my "Handbook" which is not to be found in the fourth edition of "Yarrell," in Seebohm's "History of British Birds," and other well-known works, though I have endeavoured to give the latest knowledge on the subject of the geographical distribution of our birds. My life-work as an officer of the British Museum has naturally been that of a "cabinet"-naturalist, from necessity, not from choice; but for a museum official, I think I have seen more of the birds in the field than usually falls to the lot of a stay-at-home ornithologist. Indeed, the reproach that is often hurled at museum officials, viz., that they are "two-pair-backgarret naturalists," is entirely undeserved, for, according to my experience, they spend as much time in field-work as any other professional men. Anyone looking through the published catalogue of a museum will generally find that the collections have been enriched by the exertions of the naturalists in charge of them in no small degree. Take the British Museum, for instance, which is the institution at which the gibes of the opportunist field-naturalists are generally hurled. After Lord Walsingham, it will be found that the greater number of the groups of British birds, with their nests, have been obtained by Mr. Ogilvie Grant and myself, excepting some cases of rare species contributed 
by Colonel Irby, Captain Savile Reid, and Mr. Theodore Walker. The same may be said of the collection of bird-skins; and no one would say that Salvin, Godman, Hume, Seebohm, Sclater, Shelley, or Howard Saunders, were not field-naturalists, because they were also "cabinet"-naturalists, and had written important works on ornithology. The same can be said of the ornithologists in foreign museums- of Buittikofer, the explorer of Liberia and Dutch Borneo; of Reichenow, the traveller in Aguapim and the Cameroons; of Meyer, the explorer of Celebes and New Guinea; of Hartert, the explorer of the Niger, of Assam, Perak, and Sumatra; of Forbes, of Timor Laut and New Guinea fame; and dozens of others could be mentioned. Of the American ornithologists, I believe that there is not one in charge of a museum that has not won his spurs in the field. The taunt of being "cabinet"-naturalist only falls harniless in these days, when levelled at such men and many others I could name.

My opportunities for field-work may have not been many. I have tried to make the most of them, and I feel that this is true, for nearly every vacation that I have had in my life has been spent in the study of birds in their haunts. Nevertheless, there are dozens of British birds whose nests I have never taken, and whose haunts I have never been able to visit. My own small experiences have been recorded in the present work, but where I have not been fortunate enough to have personal acquaintance with a species, I have given the best account that I could lay my hands on at the time. The space at my disposal has never been enough to go very deeply into the subject of the habits of the birds, and I have generally given a brief extract, taken from some well-known work, like that of Seebohm, or from some less-known volumes like those of Nelson, Elliot, Brehm, Saxby, \&c. At the same time, I have to acknowledge the receipt of many interesting original notes 
from friends like Mr. Robert Read, Mr. E. IV. De Winton, Mr. WV. R. Ogilvie Grant, Mr. A. Trevor-Battye, Mr. Abel Chapman, and other kind helpers, but I have taken most of my quotations on the habits of birds from Seebohm's wellknown history. I knew Seebohm intimately for many years, and accompanied him to Heligoland, and other places on the continent of Europe, and I can testify to the keenness with which he laboured to try and collect facts for his "History of British Birds." Of his ideas of "Classification," and how his facts were obtained for the demonstration of his Systems, this is not the place to speak, though I should like to take this opportunity of repudiating the idea that in my Classification of birds, published in I89 I, I was a "disciple" of Seebohm's, as Professor Newton (Dict. B. Intr. p. r ०3, note) has lately suggested; for a considerable portion of my essay is devoted to the exposure of what I consider to be errors on Seebohm's part. I have not detected any plagiarism in the latter's "History of British Birds," but, on the contrary, from my knowledge of his method of work in the field, and the ample diaries which he kept on those occasions, I believe that his notes on the habits of birds are more original than those in any other English publications except, perhaps, those of Macgillivray and Booth.

I cannot conclude this preface without acknowledging, with the utmost sincerity, the kind help and advice which I have received from my old friend Howard Saunders, without whose assistance I should never have had the courage to undertake such a laborious and tedious occupation as the preparation of even a small book like this "Handbook" has proved to be. I can only hope that its utility may be found in some way to compensate for the labour involved in its preparation.

R. BOWDLER SHARPE.

Chiswick, March iо, I897. 


\section{SYSTEMATIC INDEX.}

ORDER LARIFORMES.

PAGE

FAMILY LARIDE.

I

SUB-F.AMILY STERNINA. $\quad \ldots \quad$ F

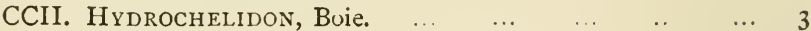

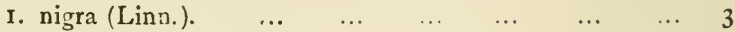

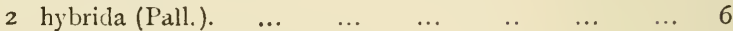

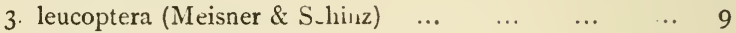

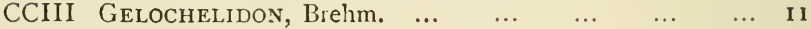

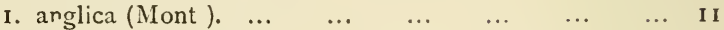

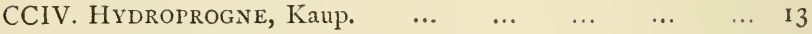

$\begin{array}{llllllll}\text { I. } \operatorname{caspia}(\text { Pall.). } & \ldots & \ldots & \ldots & \ldots & \ldots & \ldots & \text { I4 }\end{array}$

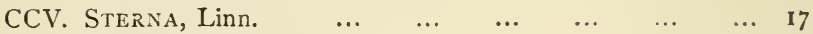

$\begin{array}{llllllll}\text { I. fluviatilis, Naum. } & \ldots & \ldots & \ldots & \ldots & \ldots & \ldots & \text { I7 }\end{array}$

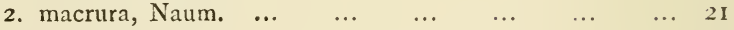

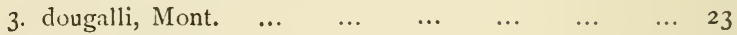

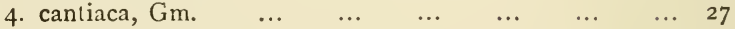

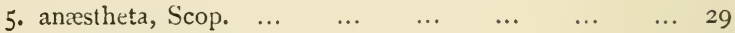

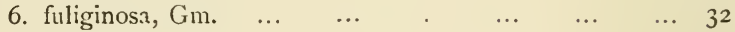

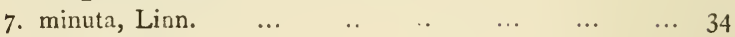

$\begin{array}{lllllllll}\text { CCVI. Anous, Steph. } & \ldots & \ldots & \ldots & \ldots & \ldots & \ldots & 37\end{array}$

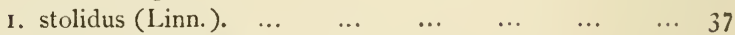

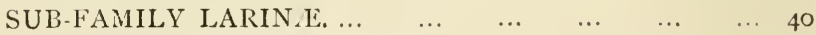

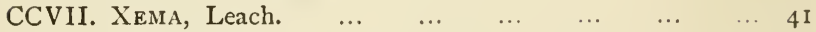

I. sabinii $\left(\begin{array}{lllllll}\text { J. Sabine).... } & \ldots & \ldots & \ldots & \ldots & \ldots & 4 \mathrm{I}\end{array}\right.$

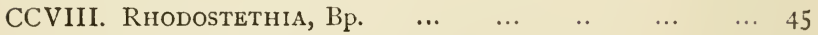

I. $\begin{array}{rlllllll}\text { rosea (Macgill.). } & \ldots & \ldots & \ldots & \ldots & \ldots & \ldots & 45\end{array}$

$\begin{array}{lllllllll}\text { CCIX. Larus, Linn... } & \ldots & \ldots & \ldots & \ldots & \ldots & \ldots & 48\end{array}$

$\begin{array}{lllllllll}\text { I. minutus, Pall. } & \ldots & \ldots & \ldots & \ldots & \ldots & \ldots & 49\end{array}$

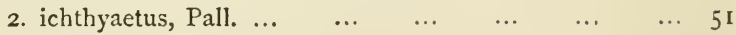

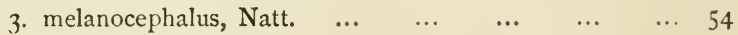

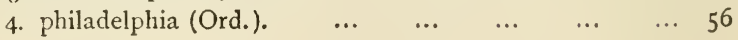


5. ridibundus, Linn.

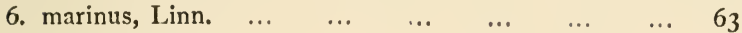

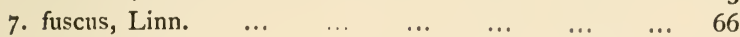

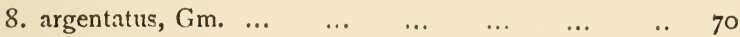

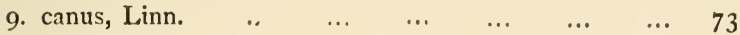

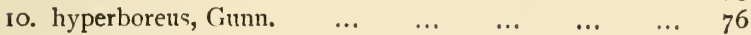

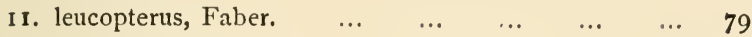

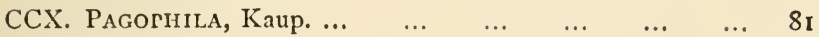

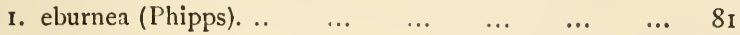

CCXI. Rissa, Steph.

$\begin{array}{lllll}\cdots & \cdots & \cdots & \ldots & 84\end{array}$

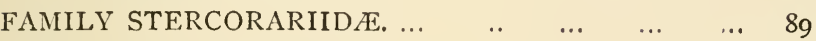

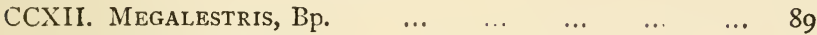

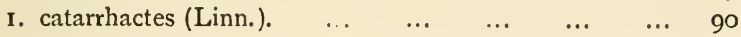

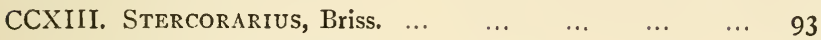

I. pomatorhinus $\left(\begin{array}{lllllll}\text { Temm. }) & \ldots & \ldots & \ldots & \ldots & \ldots & 93\end{array}\right.$

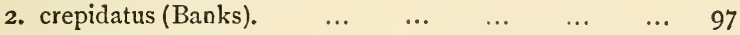

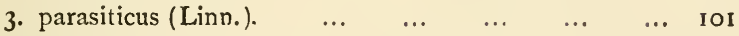

$\begin{array}{lllllllll}\text { SUB.ORDER ALCE. } & \ldots & \ldots & \ldots & \ldots & \ldots & \ldots & \text { I05 }\end{array}$

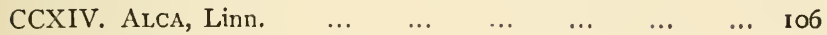

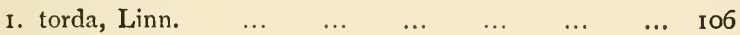

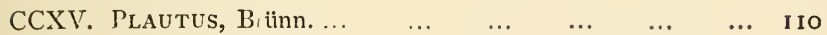

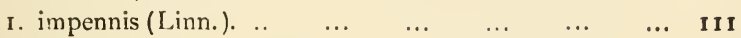

CCXVI. URIA, Briss.

... II 14

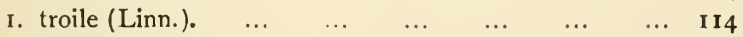

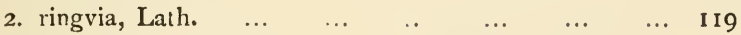

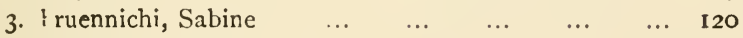

$\begin{array}{lllllllll}\text { CCXVit. Ceppitus, Pall. } & \ldots & \ldots & \ldots & \ldots & \ldots & \mathbf{1 2 3}\end{array}$

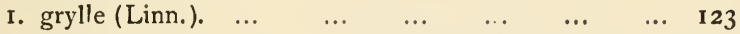

$\begin{array}{lllllllll}\text { CCXVIII. Alle, Link. } & \ldots & \ldots & \ldots & \ldots & \ldots & \ldots & 127\end{array}$

$\begin{array}{llllllll}\text { I. alle (Linn.). } & \ldots & \ldots & \ldots & \ldots & \ldots & \ldots & 127\end{array}$

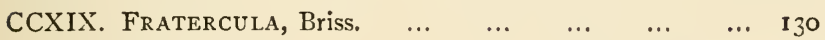

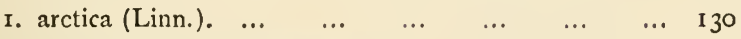

$\begin{array}{llllllll}\text { ORDER PROCELLARIIFORMES. } & \ldots & \ldots & \ldots & \ldots & \mathbf{1} 35\end{array}$

FAMILY PROCELLARIIDA. 
SUB-FAMILY PROCELLARIINA:

CCXX. Procellaria, (Linn.). ...

I. pelagica (Linn.). ... ...

CCXXI. Oceanodroma, Reichenb.

I. lencorrhoa (Vieill.).

2. cryptoleucura (Ridgw.)....

SUB-FAMILY OCEANITINA.

CCXXII. OCEAnites, Keys. u. Blas.

I. oceanicus (Kuhl.).

CCXXIII. Pelagodrona, Reichenb.

I. marina (Lath.)

FAMILY PUFFINIDA.

... 152

SUB-FAMILY FULMARINA. CCXXIV. Fulmarus, Steph.

I. GLACIALIS (Linn.).

CCXXV. Daption, Steph.

I. capensis (Linn.)

SUB-FAMILY PUFFININ E. CCXXVI. PUffinus, Briss.

I. gravis (O'Reilly)....

2. puffinus (Linn.). ...

3. yelkouanus (Acerbi).

4. obscurus (Gm.)

5. griseus (Gm.).

. 152

... 152

... 153

... 157

... 158

... 160

... 160

... 160

... 163

... 167

... 168

.. 169

CCXXViI. Eestrelata, Bp.

I. hæsitata (Kuhl). 172

2. brevipes (Peale).

I. bulweri (Jard. \& Selby)-...

ORDER COLYMBIFORMES.

I. glacialis, Linn.

.. 178

2. adamsi, Gray.

... 178

3. arcticus, Linn.

182,304

4. septentrionalis, Linn.

... 185

... 187 
ORDER PODICIPEDIDIFORMES.

CCXXX. LOPHÆTHYiA, Kaup. ...

1. cristata (Linn.).

2. griseigena (Bod.l.)

CCXXXI. Dy fES, Kaup. ...

I. auri:us (Linn.).

... 192

... 194

... 198

... $20 \mathrm{I}$

... $20 \mathrm{OI}$

CCXXXII. Proctopus, Kaup.

I nigricollis (C. L. Biehm).

CCXXXIII. Podocipes, Kaup.

I. fluviatilis (Tunst.)

CCXXXIV. Podllymbus, Less.

... 213

I. podicipes (Linn )....

.. 213

\section{ORDER RALLIFORMES.}

FAMILY RALLID.E.

... 215

SUB-FAMILY RALLINA.

CCXXXV. Rallus, Linn.

I. aquaticus, Linn. ...

.. 216

... 216

... 216

... 216

CCXXXVI. Crex, Bechst....

‥ 220

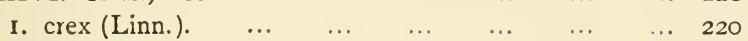

CCXXXVII. ZAPORNIA, Leach.

1. parva (Scop.).

223

... 223

CCXXXVIII. Porzana, Vieill.

I. porzana.

2. carolina (Linn.).

3. intermedia (Herm).

CCXXXIX. Gallinula, Briss.

I. chloropus (Linn.).

... 226

... 226

... 230

... 232

... 234

... 234

CCXL. Porphyrio, Briss.

... 237

SUB-FAMILY FULICINA.

... 238

CCXLI. FU:ICA, Linn.

... 238

I. atra, Linn.

.. 238

ORDER COLUMBIFORMES.

.. 240

FAMILY COLUMBIDÆ. 
SUB-FAMILY COLUMBINA....

CCXliI. Columba, Linn.

I. palumbus, Linn.

2. œnas, Linn.

3 livia, Bonn.

SUB-FAMILY ECTOPISTIN $A$.

CCXLIII. Ectopistes, Swains.

I. migratorius (Linn.).

FAMILY PERISTERIDA.

SUB-FAMILY TURTURIN E, ..

CCXLIV. Turtur, Selby.

I. turtur (Linn.).

2. orientalis (Lath.)....

ORDER PTEROCLETES.

FAMILY PTEROCLID A.

CCXLV. Syrrhaptes, Illiger.

I. paradoxus (Pall.)....

... 250

... 250

... 253

... 253

... 254

... 254

... 256

... 257

.. 259

... 259

... 260

\section{ORDER GALLIFORMES.}

FAMILY TETRAONIDE.

CCXLVI. LAgopus, Briss.

I. scoticus (Lath.). ...

2. mutus (Montin)

CCXlviI. Lykurus, Swains.

I. tetrix (Linn.).

CCXlvili. Tetrao, Linn.

I. urogallus, Linn.

.. $26 \mathrm{I}$

... 263

... 263

... 263

.. $27 \mathrm{I}$

.. 273

... 273

276

275

FAMILY PHASIANIDE

SUB-FAMILY PERDICIN $Æ$

CCXliX. Caccabis, Kaup.

I. rufa (Linn.).

280

280

280

2 So

CCL. PERdix, Briss.

282

I. perdix (Linn.)

$2 \mathrm{~S}_{2}$

CCLI. Coturnix, Bonn.

I. coturnix (Linn.).... 
SUB-FAMILY PIIASIANINA. $\quad \ldots \quad \ldots \quad \ldots \quad \ldots \quad \ldots 290$

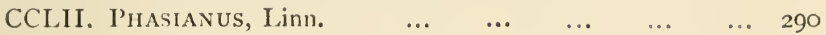

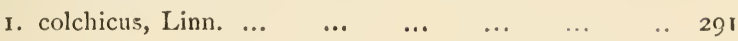

$\begin{array}{llllllllll}\text { APPENDIX. } & \ldots & \ldots & \ldots & \ldots & \ldots & \ldots & \ldots & 297\end{array}$

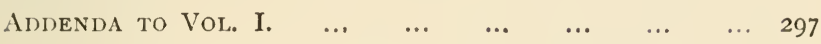

$\begin{array}{llllllllll}\text { Ligurinus chloris. } & \ldots & \ldots & \ldots & \ldots & \ldots & \ldots & \ldots & 297\end{array}$

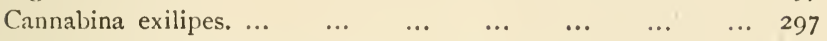

$\begin{array}{lllllllll}\text { Cannabina hornemanni. } & \ldots & \ldots & \ldots & \ldots & \ldots & \ldots & 298\end{array}$

$\begin{array}{lllllllll}\text { Pyrrhula pyrrhula. } & \ldots & \ldots & \ldots & \ldots & \ldots & \ldots & \ldots & 298\end{array}$

$\begin{array}{llllllllll}\text { Sylvia sub-alpina. } & \ldots & \ldots & \ldots & \ldots & \ldots & \ldots & \ldots & 299\end{array}$

$\begin{array}{lllllllll}\text { Phylloscopus viridanus. } & \ldots & \ldots & \ldots & \ldots & \ldots & \ldots & 300\end{array}$

$\begin{array}{lllllllll}\text { Phylloscopus proregulus. } & \ldots & \ldots & \ldots & \ldots & \ldots & \ldots & 3 \mathrm{O} 2\end{array}$

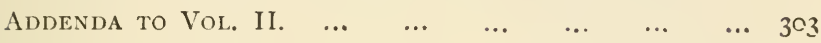

$\begin{array}{lllllllll}\text { Somateria } \text { spectabilis. } & \ldots & \ldots & \ldots & \ldots & \ldots & \ldots & 303\end{array}$

$\begin{array}{llllllllll}\text { Agialitis hiaticola. } . . . & \ldots & \ldots & \ldots & \ldots & \ldots & \ldots & 304\end{array}$

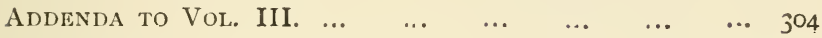

$\begin{array}{lllllllll}\text { Larus atricilla. } & \ldots & \ldots & \ldots & \ldots & \ldots & \ldots & \ldots & 304\end{array}$

$\begin{array}{lllllllll}\text { Colymbus adamsi. } & \ldots & \ldots & \ldots & \ldots & \ldots & \ldots & \ldots & 304\end{array}$

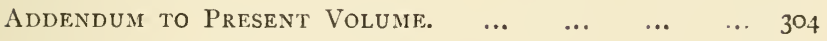

$\begin{array}{llllllllll}\text { Turtur arenicola. } & \ldots & \ldots & \ldots & \ldots & \ldots & \ldots & \ldots & 304\end{array}$ 


\section{LIST OF PLATES.}

XCIV.-Black Tern

XCV.- IVhite-winged Black Tern

XCVI._Gull-billed Tern ...

XCVII._Roseate Tern

XCVIII.-Sabine'; Gull

XCIX.-Black-headed Gull

C. -Great Black-backed Gull

CI.-Lesser Black-backed Gull

CII.-Glaucous Gull

CIII.-Richardson's Skua

CIV.-Razor-bill

CV.-Great Auk ...

CVI.-Common Guillemot

CVII.-Bridled Guillemot ...

CVIII.-Black Guillemot ...

CIX.-Little Auk ... ..

CX.-Puffin

CXIa.-Storm Petrel

CXI6.-Fork-tailed Petrel ...

CXI c.-Madeira Petrel

CXI $d_{0}$ - I White-bellied Petrel

CXI.-Fulmar

CXII. - White-throated Grey Petrel

CXIII.-White-billed Diver

CXIV.-Red-throated Diver

CXV.-Slavonian Grebe ...

CXVI.-Water-Rail ...

CXVII.-Land-Rail ...

C.IVIII.-Spotted Crake

CXIX.-Moor-Hen ...

CXX.-Common Coot

CXXI.-Wood-Pigeon

CXXII.-Stock-Dove.

CXXIII.-Common Partridge

CXXIV.-American Laughing Gull...
... $\quad \ldots \quad \ldots \quad$ Frontispicce. TO FACE PAGE 9

... $\quad \ldots \quad$ I I

$\begin{array}{lll}\ldots & \ldots & 25\end{array}$

... $\quad \ldots \quad 4$ I

$\begin{array}{lll}\ldots & \ldots & 59\end{array}$

... $\quad \ldots \quad 65$

... $\quad \ldots \quad 67$

... ... 77

$\begin{array}{lll}\ldots & \ldots & 97\end{array}$

$\begin{array}{lll}\ldots & \ldots & 107\end{array}$

... $\quad \ldots \quad$ II 3

... $\quad \ldots$ II

... $\quad$.. 119

$\begin{array}{lll}\ldots & \ldots & 123\end{array}$

$\begin{array}{lll}\ldots & \ldots & \text { I } 27\end{array}$

... $\quad \ldots \quad$ I3 I

... $\quad \ldots \quad$ I 37

... $\quad \ldots$ I 4 I

$\begin{array}{lll}\ldots & \ldots & \mathbf{1} 43\end{array}$

... $\quad \ldots \quad 149$

... 153

... 173

... 183

... $\mathrm{I} \mathrm{S}_{7}$

... $20 \mathrm{I}$

... 217

... $22 \mathrm{I}$

... 227

... 235

... 239

.. 241

... 245

... $28_{3}$

... 304 


\section{B R I T I S H B I R D S.}

\section{THE GULLS. ORDER LARIFORMES.}

THESE birds, though at first sight very different in appearance from the Plovers, are really allied to them. They possess characters, external and internal, which indicate close affinity; but they are easily recognised by the structure of their feet, the Gulls being entirely web-footed, the Plovers not. The eggs, however, of some of the smaller Terns are almost indistinguishable from some of the Plovers' eggs, and not only in the colour of the latter, but in the form of the nest, there is so much similarity that it is impossible to deny the close relationship of Terns and Plovers. The latest, and at the same time the greatest, authority on the Lariformes, Mr. Howard Saunders, has given the following characters for the Order in the British Museum "Catalogue of Birds":-The palate is "schizognathous" or split; the nasals schizorhinal. In the wing the fifth secondary is wanting, and the number of cervical vertebræ is fifteen. The young are hatched covered with down, and are able to run about in a few hours. Instead of the four eggs which form the complement of those of the Charadriiformes, the number laid by the Gulls and Terns seldom exceeds three. The Gulls are absolutely cosmopolitan in range, and they are divided into two families, the Laride, containing the Gulls and Terns, and the Stercorariida, or Skuas.

The Skuas possess a bare wax-like base to the bill, such as is seen in Birds of Prey and Parrots, but the Larida have no cere. The breast-bone in the Gulls and Terns has two notches 
on its posterior margin, whereas in the Skuas there is only one; the toes are more or less fully webbed, but the claws are small and feeble, whereas in the Skuas the latter are terribly curved and sharp.

The family Larida is divided by Mr. Howard Saunders into three sub-families, viz., the Terns (Sternine), the Skimmers or Scissor-bills (Rhynchopine), and the Gulls (Larine). The Scissor-bills are entirely tropical, and are found in South America, Africa, and India. They are river Terns, with a most peculiar bill, which is not only compressed like a knifeblade, but the lower mandible is produced far beyond the upper one. These Scissor-bills only frequent rivers, where they nest on the sand-banks.

In the compilation of the following notes on the Larida I have borrowed largely from the recent writings of Mr. Saunders. He has so completely made the subject his own, having studied the group ninutely for the past thirty years, that there seems to be little left for anyone to discover, as far as the description of the plumages go. I have therefore adopted his conclusions, and have quoted many of his notes on the plumage and habits.

\section{THE GULLS AND TERNS. FAMILY LARIDÆ.}

I have already alluded to the characters which distinguish the Larida from the Skuas, viz., the absence of a cere, the double-notched sternum, the fully webbed toes, and the feeble claws. The range of the family extends over the whole of the world.

\section{THE TERNS. SUB-FAMILY STERNINÆ.}

Although it is very difficult to say where the Terns end and the Gulls begin-for a large Tern is very like a small GullMr. Saunders has given a clear definition of the characters which distinguish the three sub-families of the Larida. To the Scissor-bills (Rhynchopina) I have already referred, and their peculiar bill separates them at once. The Terns differ from the Gulls in the form of the bill, which is slender and nearly straight, the two mandibles being almost equal in length. The tail is slightly or distinctly forked. 
The Terns are nearly cosmopolitan in their distribution, as they are found in most of the seas of the Old and New Worlds. Many are marsh and river 'Terns, as will be seen in our enumeration of the British species.

\section{TIE BLACK TERNS. GENUS HYDROCHELIDON.}

$$
\begin{gathered}
\text { Hydrochelidon, Boie, Isis, I 822, p. } 5^{6} 3 \text {. } \\
\text { Type, H. nigra (Linn.). }
\end{gathered}
$$

The Black Terns are only four in number, and three of these have occurred within our limits, namely, the White-winged Black Tern, the Whiskered Tern, and the Black Tern. The latter, $H$. nigra, is an Old World species of wide range, and is replaced in America by $H$. surinamensis, which is a darker bird with blacker feet, nesting in temperate North America, and extending to Central and South America in winter.

\section{THE BLACK TERN. HYDROCHELIDON NIGRA.}

Sterna nigra, Linn. Syst. Nat. i. p. 227 ( 766 ); Seebohm, Hist. Brit. B. iii. p. 254 (I885).

Hydrochelidon nigra, Macgill. Brit. B. v. p. $65^{8}$ (1852); Dresser, B. Eur. viii. p. 327 , pl. $592(1876)$; B. O. U. List Brit. B. p. I 85 (I883); Saunders, ed. Yarrell's Brit. B. iii. p. 5 I 6 (1884); id. Man. Brit. B. p. 6r 7 (1889); Lilford, Col. Fig. Brit. B. part xxxviii (I 894); Saunders, Cat. B. Brit. Mus. xxv. p. I7 (1896).

\section{(Plate $X C I V$.}

Nestling.-Fawn colour above, with black markings arranged in pairs on the back and sides of the rump, with a single patch on the mantle; the head with a line of black above each eye, and a triple line on the nape; sides of face white; the under surface of body clove-brown, becoming darker brown on the throat and sides of body.

Young in First Plumage.-Differs from the winter plumage of the adult in having all the feathers of the back and wings tipped with brown, this colour obscuring the whole of the 
mantle; the head and nape blackish, the forehead whiter; round the hind neck a broad collar of white; sides of face and under surface of body pure white, excepting for a patch of ashy-brown on each side of the upper breast.

Adult Male--General colour above slate-grey, a little paler on the wing-coverts, the small coverts round the carpal bend of the wing being white; the bastard-wing, primary-coverts, ard quills dark slaty-brown, externally frosted with light ashy-grey, and paler grey on the inner web, the shafts of the primaries white; the upper tail-coverts and tail-feathers slightly paler slate-colour and inclining to pearly-grey; crown of head black, overspreading the hind neck towards the mantle; the under surface of the body leaden-black, deepening on the throat and chest; thighs, sides of lower flanks, under tail-coverts, as well as the under wing-coverts, white ; the lower greater coverts pale pearly-grey like the quill lining; axillaries leaden-grey; bill black; feet reddish-brown. Total length, 9.5 inches; culmen, I.25; wing, 8.4 ; tail, 3.15 ; tarsus, 0.6 ; middle toe and claw, 0.85 .

Adult Female.-Similar to the male, but slightly paler in colour. Total length, 9.6 inches; wing, 8.x.

Adult in winter Plumage.-Distinguished by the white under surface from the summer plumage, the forehead being white, and the hinder crown and centre of the nape black, the feathers having hoary-white margins; sides of face, sides of neck, and a collar round the hind-neck white, like the under surface of the body.

Characters.-The adult Black Tern is easily recognised from the other British species of $H_{y} d r o c h e l i d o n$, in summer plumage, by its pale grey under wing-coverts, these being black in H. leucoptera and white in $H$. hybrida. The grey upper tail-coverts and tail distinguish it from $H$. leucoptera, which is black underneath, not dark leaden-grey as H. nigra is. From $H$. hybrida it may be distinguished by its black bill and black sides of the face.

In winter plumage the three species are more difficult to discriminate, but $H$. nigra and $H$. hybrida have the tail grey and the rump also grey like the back. H. nigra is a smaller 
bird than $H$. hybrida with a more slender bill, and the webs of the feet are not so much incised.

Range in Great Britain.-The Black Tern is no longer known as a breeding species in England, but in former times it used to nest in the marshes of the east coast. But for the draining of the fen-lands the species might yet be found nesting, and I have myself seen birds in full breeding plumage, passing north along the shores of the Kentish coast in May. According 10 Mr. Howard Saunders, the last recorded eggs were taken in Norfolk in 1858 , though early in the century the nests of the "Blue Darr," as the bird was called, might have been found in hundreds on the alder swamps. In the autumn the birds return southwards, and during the gales which then frequently prevail, they are driven inland along the rivers, so that I have more than once been fishing on the Thames at Cookham, in September, with several of these pretty birds flying round me, during the prevalence of a strong easterly gale. The species occurs much more rarely on the west coast of England than upon the east, and is found only as a straggler in the northern parts of the British Island, and as a rare autumn visitor to Ireland.

Range outside the British Islands.-The Black Tern breeds in suitable localities throughout Europe, south of $60^{\circ} \mathrm{N}$. lat., and as far eastwards as Western Turkestan. It winters in Africa, reaching to Loango on the west coast and the shores of Abyssinia on the east.

Habits. - When seen in spring, proceeding northward, the Black Tern follows the usual habits of the family, flying at a little distance from the shore, just out of gun shot, and dipping at intervals into the sea to capture some small prey and then beating its way onward. Under such circumstances I have seen it both in spring and autumn on the coasts of England, but in its usual haunts on the Continent it is an inland species, and I saw it in the Hanzág marshes in Hungary in May, where it was nesting. When disturbed the birds fly up, uttering a harsh note like the syllable "crick"; but they have another note more drawn out, which Mr. Seebohm very well expresses by Ke-e-e. The food of the Black Tern consists of small fishes, but it also feed on leeches, worms, and even on insects, for it 
has been known to capture dragon-flies on the wing, and, according to Mr. Howard Saunders, it has been seen by Mr. F. S. Mitchell to "swoop down on the field-crickets (Acheta cam.pestris) during their momentary appearance at the entrances of their burrows."

Nest.-The Black Tern does not begin to nest before the end of May, and it then breeds in colonies in the marshes or by shallow pools. The nest is a substantial structure of decaying plants and weeds, on heaps of wrack which rise and fall with the water, or on the firmer hummocks of the bog.

Eggs.-Three in number only. Ground colour varying from deep clay-colour or pale chocolate to greenish-grey and stonecolour or buff, the markings generally consisting of black blotches, which are mostly confluent. Sometimes the markings are smaller and take the form of scattered dots or scribblings. The underlying spots are grey and are not very distinct. In the Seebohm collection in the British Museum there are some specimens in which the spots and blotches are perceptibly rufous, though generally they range from a dark chocolatebrown to absolute black. Axis, ${ }^{\circ} 3-\mathrm{I}^{\prime} 45$ inch; diam., 0.9 $-1 \cdot 05$.

11. THE WHISKERED TERN. HYDROCHELIDON HYBRIDA.

Sterna hybrida, Pallas, Zoogr. Rosso-Asiat. ii. p. 338 (181 I); Seebohm, Hist. Brit. B. iii. p. 260 (1885).

Hydrochelidon leucopareia (Natt.); Macgill. Brit. B. v. p. 663 (I852).

Hydrochelidon hybrida, Dresser, B. Eur. viii. p. 315, pls. 588, $589(1887)$; B. O. U. List Brit. B. p. I84 (1883); Saunders, ed. Yarrell's Brit. B. iii. p. 527 (I884); id. Man. Brit. B. p. 62 I (I889); Lilford, Col. Fig. Brit. B. part. xxviii. (זE94) ; Saunders, Cat. B. Brit. Mus. xxv. p ro (1896).

Adult Male--General colour above light slaty-grey; lower back, rump, upper tail-coverts and tail of the same colour as the rest of the back, the outermost tail-feather being white along the outer web; wing-coverts like the back; quills dusky, frosted with pearly-grey on the outer webs; the shafts of the primaries white, the outer ones with the greater part of the 
inner webs also white; crown of head and nape black; under surface of body slaty-grey, deepening into blackish towards the abdomen and paling into white towards the chin ; sides of face from the base of the bill to the sides of the neck white, forming a band which contrasts strongly with the black head and grey cheeks; under tail-coverts, under wing-coverts, and axillaries, pure white or with a slight tinge of grey on the latter; "bill blood-red ; feet vermilion, drying to orange colour" (Saunders). Total length, 10.5 inches; culmen, 1.3 ; wing, 9.3 ; tail, 3.45 ; tarsus, $0^{\circ} 9$.

Adult Female.-Similar to the male, but somewhat paler in colour. Total length, 9.7 inches; wing, 8.9.

Adult in winter Plumage.-Differs from the summer plumage in being white underneath, and in having a white collar round the hind neck; crown of head white, mottled and spotted with black on the hinder crown and nape, and the upper surface paler grey.

Young.-Differs from the winter plumage of the adult in having the hinder part of the head blacker, and the upper surface of the body mottled with large or small black spots which are varied with sandy-buff spots or bars.

Nestling.-Sandy-buff, inclining to golden-buff on the forehead and mantle; the upper surface prettily striped or spotted with regular lines of black; the throat sooty black; rest of under parts white, the sides of the body being sandy-buff.

Characters.-The adult bird is easily distinguished from $H$. leucoptera by the grey upper and under tail-coverts, and from H. nigra by the red bill and white chin and sides of face, as well as by the white under wing-coverts. In winter plumage the species may be distinguished from the adult of $H$. leucoptera by its grey tail, and from the young of the latter species, which has a grey tail, by the absence of white on the rump, which is to be found in the young of the White-winged Black Tern. In winter plumage $H$. hybrida has a grey rump, like the back, and it thus resembles the winter dress of $H$. nigra, but it is a larger bird than the latter, has a stouter bill, and has the webs of the feet much incised. 
Range in Great Britain.-The Whiskered Tern is an accidental visitor to the British Islands, and the occurrences of the species are only some half-dozen at number, specimens having been obtained in Cornwall, Devonshire, Dorsetshire, Norfolk, and Yorkshire; while Ireland has one record from the River Liffey. One of these birds was obtained in May, another on Hickling Broad in June, and the remainder in autumn.

Range Outside the Eritish Islands.--This is a species of Southern Europe, rarely reaching Northern Germany and the British Islands; but it extends eastwards at about the same latitude to China, and visits Africa, India (breeding in both these countries), and the Malayan Archipelago, as far as Australia, in winter. It apparently wanders to the eastern coasts of America occasionally, as the British Museum possesses a specimen procured by Sir R. Schomburgk in Barbados.

Habits.-Like the preceding species, this is a Marsh Tern, and in habits it resembles $/$. nigra, the food being the same in both species. It nests in colonies.

Nest.-This is generally a mass of weeds, and is often found floating on the surface of the water. In Southern Spain, where large colonies of the Whiskered Tern are met with, Major Willoughby Verner visited a breeding-colony of these birds at La Janda, on the 7 th of May, I 875, and found several hundred nests floating on the top of the water; they were simple platforms of reeds and rushes, and were kept from drifting to some extent by the young rushes growing up in the water. Only iwo nests contained a single egg. Five days later over thirty nests contained eggs. In the interval between the visits a strong wind had arisen, and had blown away many of the Terns' nests along the water, till they were packed in a dense mass on the lee side of the Laguna.*

Eggs.-Three in number. Prevailing ground-colour greenish-grey, sometimes clay-colour, the markings of the eggs being similar in character to those of the allied Terns, but rather nore scattered and distinct, while in some examples the

* Irby, Orn. Straits Gibraltar, 2nd ed., p. 293. 

3
0
$x$
0

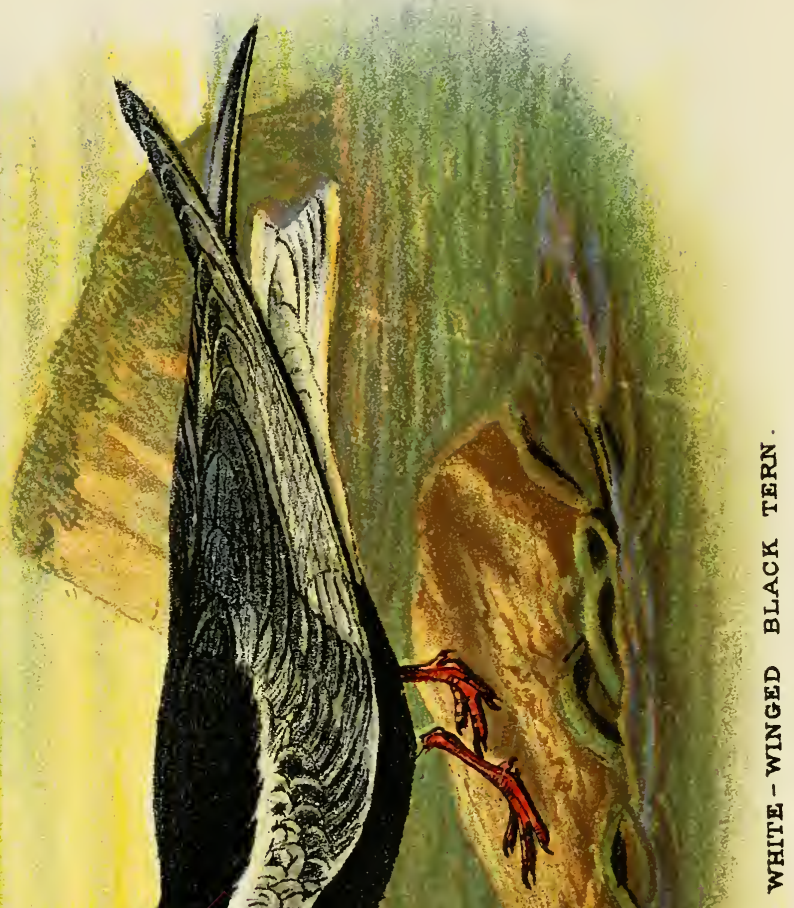


spotting and scribbling is very minute, and the underlying grey spots are more distinct than in eggs of $I I$. leucoptera.

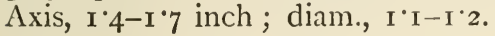

III. THE WHITE-WINGED BLACK TERN. HYDROCHELIDON LEUCOPTERA.

Sterna leucoptera, Meisner \& Schinz, Vög. Schweiz, p. 264 (18I5); Seebohm, Hist. Brit. B. iii. p. 257 (1885). Hydrochelidon leucoptera, Macgill. Brit. B. v. p. 66 I (1852); Dresser, B. Eur. viii. p. $32 \mathrm{I}$, pls. 590, 59I (1875); B. O. U. List Brit. B. P I85 (1883); Saunders, ed. Yarrell's Brit. B. iii. p. $55^{2}$ (1884); id. Man. Brit. B. p. 619 (1889); Lilford, Col. Fig. Brit. B. part xxix. (1894); Saunders, Cat. B. Brit. Mus. xxv. p. 6 (1896).

(Plate XCV.)

Adult Male.-General colour above dark slate-colour; head and neck black, this colour overspreading the mantle; lower back, rump, upper tail-coverts, and tail pure white; lesser coverts round the bend of the wing white, the rest of the wing-coverts pearly-grey, the innermost greater coverts rather darker and more slaty-grey; bastard-wing, primary-coverts, and quills dusky, externally frosted with pearly-grey, the inner primaries being almost entirely of this colour, the innermost secondaries darker slate-grey; entire under surface of body, from the chin to the vent, black, including the under wingcoverts and axillaries; vent, under tail-coverts, and edge of wing pure white; "bill livid red; feet orange red "(H. Saunders). Total length, $9{ }^{\circ} \circ$ inches; culmen, 0.95 ; wing, 8.0 ; tail, 2.7 ; tarsus, $0 \% 7$.

Adult Female.-Similar to the male in colour. Total length, 8.7 inches; wing, 8.3 .

Adult in Winter Plumage.-Differs from the summer plumage in being pearly-grey above and white below, a collar round the hind neck and forehead also white ; fore part of crown mottled with black, which is much more apparent on the nape, and forms a spot on the ear-coverts. 
Young.-Similar to the winter plumage of the adult, but browner, by reason of the brown tips to all the feathers of the upper surface; a black patch on the hinder crown and nape as weil as a black spot on the ear-coverts, the latter much more distinct.

Characters. - In summer plumage the present species is easily distinguished from its British allies by its white upper tailcoverts and tail, its black under surface and under wing-coverts, and by the white wing-coverts along the carpal bend of the wing. In winter plumage the adult bird is still known by its white tail, but young birds have grey tails like the winter plumage of the other species of Hydrochelidon. In a properly prepared skin, however, there is always some white on the rump, intervening between the grey of the back and the grey of the tail, in $H$. leucoptera.

Range in Great Britain.-The White-winged Black Tern has occurred many times on our southern and eastern coasts in summer, and Mr. Howard Saunders states that he knows of only two occurrences of the bird in autumn, one having been killed near Ilfracombe in North Devonshire in November, while another was shot in Dublin Bay in October, I841. Two others have been shot in Ireland in spring.

Range outside the British Islands. - The present species nests in the marshes of Central and Southern Europe and throughout temperate Asia to China, wintering all over Africa, certain parts of India and Ceylon, and throughout the Malayan Archipelago to Australia and New Zealand. It occasionally wanders to America, where it has been recorded from Wisconsin and from Barbados.

Habits.-These appear to be very similar to those of the Black Tern, in company with which it nests in Central Europe, but in Southern Russia Mr. Howard Saunders says that large and distinct colonies are formed. The flight is said by the same observer to be more rapid and its note to be harsher than that of $H$. nigra, but its food is similar to that of the lastnamed species.

Nest.-Similar to that of the Black Tern. 
Egrs.-Three in number. Ground-colour deep clay or stone-buff with an olive shade, spotted with chocolate-brown, deepening to blackish and forming irregular blotches on different parts of the egg, as much in the middle as towards the end of the latter. The underlying marks of grey are not very evident. Axis, I’35-I*45; diam., 0*95-I*05.

TIIE GULL-BILLED TERNS. GENUS GELOCIIELIDON.

Gelochelidon, Brehm, Vög. Deutschl. p. 774 (г83 г.)

$$
\text { Type, G. anglica (Mont.) }
$$

In this genus the outer tail-feathers are very pointed, and exceed the others in length. The bill is very stout and obtuse ; the tarsus is longer than in most of the Terns, and exceeds the middle toe and claw in length; the tail is short, being less than half the length of the wing.

The single species, $G$. anglica, is found in the temperate and warm portions of the Atlantic Ocean on both sides, also in the Indian Ocean and Australian seas, but it is not known from the Pacific side of America.

\section{THE GULL-BILLED TERN. GELOCHELIDON ANGLICA.}

Sterna anglica, Mont. Orn. Dict. Suppl. (1813); Dresser, B. Eur. viii. p. 295 , pl. 585 (I877) ; B. O. U. List Brit. B. p. I 82 (I883) ; Saunders, ed. Yarrell's Brit. B. iii. p. 53 I (I884); Seebohm, Hist. Brit. B. iii. p. 263 (I 885 ); Saunders, Man. Brit. B. p. 623 (1889); Lilford, Col. Fig. Brit. B. part xxix. (I 894).

Gelochelition anglica, Macgill. Brit. B. v. p. 666 (1 852$)$; Saunders, Cat. B. Brit. Mus. xxv. p. 25 (i 896 ).

\section{(Plate XCVI.)}

Adult Male.-General colour above pearly-grey, including the wings and tail, the outer feathers of the latter inclining to greyish-white on the outer webs; quills darker ashy-grey, frosted with pearly-grey externally, the primaries with white shafts and a great deal of white along the inner web; secondaries narrowly edged with white at the tips; head and 
nape glossy-black, continued into a nuchal crest and extending across the upper part of the lores to the base of the nostrils lower part of the lores, sides of face, and entire under surface of body white, including the under wing-coverts and axillaries; " bill black, occasionally reddish at the base of the lower mandible; tarsi and toes black with a reddish tinge ; iris hazelbrown" (H. Saunders). Total length, I4.5 inches; exposed part of culmen, I.6 ; wing, I $2 \cdot 5$; tail, $5^{\circ} \circ$; tarsus $I^{\circ} 5$.

Adult Female.--Similar to the male, but somewhat s maller and the bill not quite so robust. Total length, $14^{\circ} \mathrm{O}$ inches; wing, I $2^{\circ} \circ$.

Adult in winter Plumage.-Differs from the summer plumage in being slightly paler, the wings more frosted with hoary-grey, and the white on the outer tail-feathers more distinct than in summer; crown of head white, the hinder crown narrowly streaked with black and mottled with black on the nape; in front of the eye a black spot.

Young.-Similar to the winter plumage of the adult, but the streaks on the head greyish-brown and not so distinct, the whole of the grey colour of the upper surface obscured by ashybrown or brownish-buff, the feathers being mottled with a sub-terminal bar of darker brown.

Nestling.--Stone-buff, with black streaks and spots along the back and on the head and sides of the crown; under surface of body dull white.

Characters.-These are given under the heading of the genus.

Range in Great Britain.-The Gull-billed Tern is only an accidental visitor to England, having occurred several times in spring and summer, principally in Norfolk, but also at different places on the south coast, the most northerly occurrences having taken place near Blackpool in Lancashire, and near I,ceds in Yorkshire. One specimen has been recorded from Belfast Lough in Ireland, but having been submitted to Mr. Saunders, he found it to be an Arctic Tern!

Range outside the British Islands.-In the Old World the Gull. 
billed Tern nests with greater or less frequency throughout the Mediterranean region and occurs accidentally in more northern localities, though it breeds regularly on the western coast of Denmark and the island of Sylt. Its range extends through temperate Asia to Southern China, whence it is found through the Malayan Archipelago to Australia, breeding in the latter continent. In North America it occurs on the eastern side from New Jersey southwards, reaching to the Argentine Republic, but not occuring on the Pacific side except on the coast of Guatemala.

Habits.-The food of this species consists of small fish, frogs, and crustacea, and it also feeds on grasshoppers, locusts, and beetles, besides other flying insects. During the breeding season Mr. Saunders says that the note is like the syllables che-ah, but at other times the bird utters a laughing af-af-af like a Gull.

Nest.-Seebohm visited a colony of Gull-billed Terns on an island in a lagoon off the coast of Asia Minor. The nests were either a natural depression in the sand, or consisted of a slight hollow made by the birds themselves, with a few bits of seaweed or dead grass as an apology for a nest.

Eggs.-Generally two, sometimes three in number, and intermediate in character between the eggs of Gulls and Terns. The general colour is a pale stone-buff, occasionally with an olive-greenish tinge, the spots never very large and distributed over the egg in tolerably equal profusion and seldom forming blotches of any size. The underlying markings are as large and almost as much in evidence as the dark overlying ones, sometimes being even more distinct than the latter. Axis, $\mathrm{I} \cdot 8-2 \cdot 5$ inches; diam., $\mathrm{I} \cdot 35^{-\mathrm{I}} \cdot 55$.

THE GIANT TERNS. GENUS HYDROPROGNE.

$$
\begin{gathered}
\text { Iydroprogne, Kaup, Natürl. Syst. p. 9I (I\$29). } \\
\text { Type, H. caspia (Pall.). }
\end{gathered}
$$

This genus is represented by a single species, of nearly cusmopolitan range. It is distinguished by its large size and blood-red bill, The outer tail-feathers are pointed, and exceed 
the others in length. The tarsus is short, being less than the middle toe and claw in length, and the tail is very short, being less than one-third of the length of the wing.

\section{THE CASPIAN TERN. HYDROPROGNE CASPIA.}

Sterna caspia, Pall. Nov. Comm. Petrop. xiv. i. p. 582, tab. xxii. fig. 2 ( 770 ) ; Dresser, B. Eur. viii. p. 289, pl. 584 (I 877 ); B. O. U. List Brit. B. p. I 82 (1883); Saunders, ed. Yarrell's Brit. B. iii. p. 536 (I 884 ); Seebohm, Hist. Brit. B. iii. p. 268 (I 885 ) ; Saunders, Man. Brit. B. p. 625 (I889);

Lilford, Col. Fig. Brit. B. part xxviii. (I894).

Sylochelidon caspia, Macgill. Brit. B. v. p. 626 (1852).

Hydroprogne caspia, Saunders, Cat. B. Brit. Mus. xxv. p. 32 (1896).

Adult Male.-General colour above pearly-grey, the rump and upper tail-coverts like the back and hardly any paler in tint; wing-coverts like the back, the bastard-wing and primarycoverts rather paler grey and more frosted in appearance; primaries grey with white shafts, the greater part of the webs frosted, the inner web blackish along the inner margin, this blackish shade increasing in extent towards the outermost primaries, and occupying the entire inner web of the first one; secondaries like the back, with the inner webs slightly more dusky-grey; tail pearly-grey, with white shafts to the feathers, the outermost pointed and only slightly exceeding the others in length; crown of head and nape glossy black, the crest not elongated; this black extending below the eyes in a straight line from the base of the upper mandible across the lores; remainder of the lores, sides of face, exr-coverts, and a spot under the eyes white, like the entire under surface of the body; axillaries and under wing-crests white, the inner face of the primaries distinctly blackish; "bill vermilion-red, sometimes horn-coloured at tip; tarsi and toes black" (Saunders). Total length, 19 inches; culmen, 2.65 ; wing, 16.5 ; tail, 5.5 ; tarsus, I. 8 .

Adult Female. - Not to be distinguished from the male in colour, but with a weaker and less brilliantly coloured bill. Total length, 19 inches; culmer 2.5 ; wing, 16.6 ; tail, 6.2 ; tarsus, $\mathrm{r} \cdot 65$. 
Adult in winter Plumage.-Similar to the summer plumage, but distinguished by the colour of the crown, which, instead of being wholly black, is white, with broad central streaks of black, the sides of the face being similarly marked.

Immature Birds.-Resemble the winter plumage of the adults as regards the crown of the head, but the black round the eye and above the ear-coverts is uniform. The back is pearly-grey in contrast to the lower back, rump, and upper tail-coverts, which are whiter. On the wings, tail, and upper surface of the body, in places, are blacker bars or arrow-head markings, indicating immaturity.

Nestling (one day old).-Above, pale buff, inconspicuously mottled with dull brown; under parts dull white. Older nestlings show a greyer tint above (Saunders).

Characters.-The Caspian Tern is distinguished by its large size and stout red bill. Other characters are given under the heading of the genus.

Range in Great Britain.-Nine specimens of the Caspian Tern have been recorded from Norfolk, and others have been seen off the eastern and southern coasts of England from Yorkshire and Lincolnshire and Dorset. Mr. E. Bidwell informed Mr. Howard Saunders that he had seen an individual of this species off the Farne Islands on the 6th of June, I880. It has not yet been recorded from Scotland or Ireland, and the number of specimens noted in the United Kingdom is under twenty.

Range Outside the British Islands.--The present species is found throughout the Mediterranean countries, and its breeding range in Europe extends to about $60^{\circ} \mathrm{N}$. lat, as it nests on the islands of Sylt and other localities in the Baltic. Mr. Howard Saunders believes that it may also breed, or recently bred, on the Dutch coast. It breeds in many parts of Asia, but does not reach to Japan, and it also inhabits Australia and New Zealand. To many countries bordering the Indian Ocean the Caspian Tern is only a winter visitor, as it is to Africa, but it nests along the shores of the I'ersian Gulf and in Ceylon. In North America it occurs on both coasts, from a little beyond the Arctic Circle to Florida on the Atlantic side and to California on the west. 
Habits.- This species, says Mr. Saunders, "is nearly as partial to brackish lakes as to the sea-shore, and when searching for food it has a characteristic habit of keeping its bill pointed downwards, almost at a right angle to its body:" As might lie expected from such a powerful bird, its nature is bold, and it makes a vigorous out-cry when its nest is attacked, some of the birds swooping down within a few yards of the intruder's head, while the rest of the colony fly round in the air above, and add their cries to the general expostulation. Mr. H. Parker thus describes his experience of the nesting of the Caspian Tern in Ceylon :-

"The birds at first circled round for a short time, and afterwards joined a large party of other Terns at a small neighbouring bank, from which some of them made îrequent sallies, flying over my head a few times and then returning." Their cry was a hoarse croak or a scream.

"Later in the day I found a pair evidently breeding at another bank beyond that at which my expedition ended, but I could not spare time to visit it. They came out boldly to attack my men, and made very determined swoops, often coming within three feet of my head. They then rose vertically above me for fifty or sixty feet, and after flying back towards the nests returned to renew the assaults. The more timid of the birds, which I presume was the female, occasionally settled on the nest for a short time, while the male was engaged in bullying me. As I told him at the time, it was nothing else, for I had not attempted to molest him, and the nest was certainly quite half a mile away."

The food of the Caspian Tern seems to consist almost entirely of fish, but it is said to rob other birds' nests of their eggs, and to devour young birds as well.

Nest.-A slight depression in the sand, occasionally lined with pieces of shell or a few bents.

Eggs.-Two or three in number, laid in May or June. There is considerable similarity in the eggs of the Caspian Tern to those of the Gull-billed Tern, though they are, of course, much larger. The general colour is greyish or stone-buff, sometimes approaching buffy-white, and the markings consist of scattered spots, seldom confluent, of chocolate-brown or even blackish, 
while occasionally they are pale olive-brown. The underlying spots are purplish-grey, and are always distinct. Axis, 2.3-2.6 inches; diam. $\mathrm{I} \cdot 7-\mathrm{r} \cdot 85$.

\section{THE TRUE TERNS. GENUS STERNA.}

Sterna, Linn. Syst. Nat. i. p. 227 ( г 766$)$.

Type, probably S. fuviatilis (Naum).

Like the preceding genera, the Terns have the outermost tail-feathers much longer than the rest, and pointed. They differ from Gelochelidon in having a short tarsus, which measures less than the middle toe and claw, and in the case of the genus Sterna never exceeds the latter. The tail, according to Mr. Howard Saunders, is at least half, and generally more than half, the length of the wing. The True Terns are also remarkable for their compressed and slender bill.

They are world-wide in their distribution, and are almost exclusively maritime in their haunts.

Intermediate between the Caspian Terns and the genus Sterna is the Indian genus Seena, which has a single riverhaunting species, Seena seena (Sykes), remarkable for its stout bill, which has the genys very short, and its long tail, which is more than three-fourths the length of the wing.

\section{THE COMMON TERN. STERNA FLUVIATILIS.}

Slerna fluviatilis, Naum. Isis, I819, pp. I 847,1848 ; I)resser, B. Eur. viii. p. 263 , pl. $580(1872)$; B. O. U. List. Brit. B. p. 180 (I883); Saunders, ed. Yarrell's Brit. B. iii. p. 549 (1884); id. Man. Brit. B. p. 63 I (I889); Lilford, Col. Fig. Brit. B. part xx. (I89 I); Saunders, Cat. B. Brit. Mlus. xxv. p. $54(1896)$.

Sterna hirundo, Lath. ; Macgill. Brit. B. v. p. 638 (1852); Seebohm, Hist. Brit. B. iii. p. 280 (I885).

Adult Males.-General colour about pearl-grey, including the wing-coverts and scapulars, the latter white at the ends; rump and upper tail-coverts white; primary-coverts pearl-grey, with the inner webs more dusky; primaries dark grey externally, with white shafts, accompanied by a blacker border along its 
inner aspect, conspicuous on the inner web, to the tip of which it extends, becomes there frosted with grey, and ascends along the margin of the inner web for some little distance; the first primary blackish along the whole of the outer web; secondaries grey, with dusky shaft-lines, white along the inner webs and at the tips of the innermost quills; central tail-feathers white, the rest white with a grey shade on the outer web, increasing towards the outer ones, the external long feathers having a dusky blackish outer web; crown of head and nape black, this being drawn through the upper half of the lores and along the sides of the crown above the ear-coverts; sides of face from the lower portion of the lores, and reaching to the eye and over the ear-coverts, cheeks, and throat pure white; remainder of the under surface of the body, from the fore-neck downwards, delicate lavender grey ; under tail-coverts, under wing-coverts and axillaries pure white; "bill coral-red, the extreme tip horn-colour; feet coral-red; iris dark brown. Total length, I 5 inches; culmen, 1.55 ; wing, 10.8 ; tail, 2.7 ; outer tail-feathers, $7 \cdot 7$; tarsus, 0.85 .

Adult Female.-Similar in colour to the male. Total length, I 2.5 inches; culmen, I.35; wing, 10.7 ; tail, 5.7 ; tarsus, 0.7 .

Adult in Winter Plumage.-Differs from the summer plumage in wanting the black cap, the head being black behind, but with the forehead and crown streaked and mottled with white; the under surface of the body is paler and shows less grey; the bill and feet much duller in colour.

Inmature Birds in First Winter.-Resemble the winter plumage of the adults, but are distinguished by the forehead being white, and by a dark grey band along the marginal upper wing-coverts. The under surface of the body is entirely white.

Nestling.-Brownish-buff, or stone-buff streaked and spotted with black, without any very distinct pattern, the head lighter than the back, and more minutely spotted; edge of wing and under parts white, browner on the belly and vent; lores, sides of face, and throat brown. As the nestling grows in size the black pattern on the upper parts becomes more distinct, and the throat fades to a light-brown colour.

After the downy stage, the feathers of the upper surface are 
all mottled with sandy-buff tips, before which is a distinct bar of blackish.

Range in Great Britain.-I cannot do better than quote the remarks of Mr. Saunders as to the distribution of the present species in the British Isles. He writes:-_Broadly speaking, I believe that the Common Tern is the predominant species along the shores of the Channel, and on the west side of Great Britain as far north as the Isle of Skye; while on the east it is found from Kent to the Moray Firth, and was the only species that I observed near Nairn during August, I 885 . Continuing northwards, we find it yielding numerically to the Arctic Tern, and showing a liking for fresh-water locks or cstuaries rather than for exposed islands, though Mr. HarvieBrown states that in 1885 it was nesting abundantly at the west end of the Pentland Skerries, while the eastern was occupied by a colony of Arctic Terns. I have no conclusive evidence of the occurrence of the Common Tern in the Shetlands, Orkneys, or Outer Hebrides." Mr. R. J. Ussher says that in Ireland it breeds on islands off the coasts of most of the maritime counties, and also on lakes in J.ondonderry, Antrim, Tyrone, Armagh, Fermanagh, Cavan, Longford, Roscommon, Mayo, and Leitrim.

Range outside the British Islands.-The Common Tern is found breeding on the coasts, rivers, and inland lakes of nearly every country in Europe, from Norway southwards, and the same may be said of the whole of Central Asia to the highlands of Cashmere and Thibet. In winter its range extends to India and Ceylon, and the coasts of Western and Southern Africa. It also inhabits temperate North America, breeding as far south as Texas, visiting the IVest Indies in winter, whence it also extends to Brazil. It is almost unrecorded from the Pacific coast of North America, but an immature bird was shot by Mr. Osbert Salvin at San José de Guatemala in December, I\$62.

Habits.- The motions of this pretty bird in the air are full of grace, and as it flies along the sea-shore at a little distance from the land, it looks like a slender and graceful Gull, not in the least adopting the swift motions of a Swallow, although "Seaswallow" is the name generally applied to it. The Common 
Tern breeds in colonies, usually on a shingly beach, and the whereabouts of the eggs or young can generally be discovered by the anxiety betrayed by the old birds, who hover over the spot and keep up a loud chorus of disapproval at the intrusion. The young are so like the surrounding shingle in gencral appearance that they are very difficult to distinguish, especially as they do not run along the ground like the nestlings of the Sand-Plovers, but are fed by the parent-birds for some days at least. The old birds bring fish to their little ones, and have been known to drop them near to the latter, despite the presence of a stranger in their midst.

The food of the Common Tern consists of small coal-fish, sand-eels, shrimps, and small crustacea ; and it is a very pretty sight to see a flock of Terns fishing above a shoal of small fry and dipping after their prey. In the autumn, before their departure for the south, flocks assemble on the sand or shingly beaches, and rest quietly during the time that the tide is out. I have seen many large assemblages of these birds on the beach near Lydd in Kent, and at the incoming of the tide into Romney Hoy, especially if this took place towards evening, large flocks of terns would often follow the rush of the water as it entered the principal channel, and a constant chorus of their creaking note, like the syllables kree-e-e, was kept up, until at times there was a perfect babel of sound. The birds were apparently feeding on the small fish which came in with the tide.

Nest.-A hollow in the sand or shingle; or on the bare earth, when the birds breed at a little distance from the water. Sometimes a few stems of grass are added as a lining. Mr. Robert Read sends me the accompanying note :- "The nesting habits of this bird differ much according to site. When the nest is made on the sea-shore it usually consists simply of a slight hollow scraped in the sand or shingle without any lining materials whatever. When, however, the nest is built inland, on sivampy ground, it consists of a more or less substantial structure of dried grasses and stalks, doubtless to keep the eggs out of the damp."

Eggs.--Mr. Read adds :- " Three is the usual number of eggs laid, but on more than one occasion I have taken four 
eggrs from a nest, all apparently laid by the same bird." The general colour of the eggs varies from stone-colour to ochreousbuff or olive-buff with spots or drops of black often merging into confluent blotches, the underlying spots being faint purplish-grey and not very distinct. Sometimes the variation in the depth of the colour of the eggs is very marked, and the ground-colour is so deep a rufous-brown that the black markings are scarcely perceptible. The markings are generally distributed over the surface of the egg, but are sometimes congregated in confluent blotches round the larger end. Axis, $\mathrm{I}^{\circ} \mathbf{3 5}^{-}$ I 75 inches; diam., $\mathbf{I} \cdot \mathbf{I}-\mathbf{I} 3$.

\section{THE ARCTIC TERN. STERNA MACRURA.}

Sterna macrura, Naum. Isis, I 8 I 9, p. I 847 ; B. O. U. List. Brit. B. p. I 80 ( $\left.188_{3}\right)$; Saunders, ed. Yarrell's Brit. B. iii. p. 553 (I 884 ) ; id. Man. Brit. B. p. 633 (I889); Lilford, Col. Fig. Brit. B. part xxviii. (I894) ; Saunders, Cat. B. Brit. Mus. xxv. p. 62 (1896.)

Sterna arctica, Temm. ; Macgill. Brit. B. v. p. 643 (I852); Seebohm, Hist. Brit. B. iii. p. 284 (1885.)

Sterna hirundo, Müller (nec Lath.); Dresser, B. Eur. viii. p. 255 , pl. 579 (1872.)

Adult Male.-Similar to $S$. fuviatilis, but distinguished by its entirely red bill with no dark tips, and by the much narrower and less distinct dark edging along the inner aspect of the white shaft of the primaries. According to Mr. Howard Saunders the tarsus is shorter than in the Common Tern, and does not exceed the length of the middle toe without the claw ; "bill blood-red; feet coral-red ; iris dark-brown." Total length, I 4.5 inches; culmen, $\mathrm{I}^{\circ} 5$; wings, 10.8 ; tail, $7{ }^{\circ}$; tarsus, 0.65 .

Adult Female.-Similar to the male, but with the outer feathers rather shorter. Total length, I4 inches; wing, I0.5.

Adult in Winter Plumage.-Differs from the summer plumage in wanting the black cap; the forehead and crown being mottled with white, and the hinder crown and nape from the eyes backwards black; under parts whiter, with scarcely any grey shade on the breast; bill and feet duller. 
Immature Birds in Winter.-These resemble in co'our the winter plumage of the adult, but, according to Mr. Howard Saunders, have the forehead and crown nearly white, $a$ dark grey band on the upper wing-coz'erts, more grey on the outer webs of the tail-feathers, the under parts white, and the bill and feet nearly black.

Nestling.-Mr. Saunders remarks that there is scarcely any difference between the nestlings of the Arctic and Common Terns, but the former has a tendency to more pronounced black on the throat; the upper parts have a buffish groundcolour which seems to be very variable in tint.

Young.-Can always be distinguished from the old ones by the sandy-buff bars on the upper surface. The bill is yellow at the base, with the tip horn-colour; the feet (says Mr. Saunders) are yellow up to October, afterwards browner. The forehead is white, the occiput blackish, the sides of the neck and flanks tinged with buff, and there is a considerable amount of grey on the outer webs of the tail-feathers.

Range in Great Britain.-The breeding range of the Arctic Tern is more northerly than that of the Common Tern, as it nests from the Humber to the Farne Islands northwards along the east coast of Scotland to the Orkneys and the Shetlands, being the only species of Tern which breeds in the latter group of islands. On the west coast of Scotland it breeds as far south as the Isle of Skye, and in former times it was known to do so as far south as Cornwall. In its southern nesting area, however, it seems to be out-numbered by the Common Tern. In Ireland, Mr. R. J. Ussher says it "breeds on islands off the coast, usually in company with the Common Tern, in Donegal, Antrim, Down, Dublin, IVexford, Cork, Kerry, Galway, and Mayo. A few breed on an inland lake, Lough Carra, in Mayo." Along the shores of Great Britain it occurs everywhere on migration, but seldom appears inland.

Range outside the British Islands. - The distribution of the Arctic Tern is thus summed up by Mr. Saunders in the twenty-fifth volume of the "Catalogue of Birds" :- "Circumpolar and northern regions of the Old and New Worlds, 
breeding from $82^{\circ} \mathrm{N}$. lat. (or higher ?) down to about $50^{\circ} \mathrm{N}$. in Europe and $42^{\circ}$ in America. In winter southwards to the coasts and waters of Peru, Chili, Brazil, Africa, and even to $66^{\circ}$ S. lat. in the Southern Ocean."

Habits.-In its mode of life the present species differs but little from the Common Tern. It is very bold when its nests are in danger, and not only drives off Gulls and Skuas, but will also swoop at any man who approaches the vicinity of its nest. The young birds assemble in flocks after the nesting season, and Mr. E. W. Nelson says that in Alaska, towards the middle of August, they are very common on the marshes, and follow an intruder about from place to place, uttering an odd, squeaky imitation of the notes of the adult birds. They heedlessly hover close over head, and the expression of innocent wonder in their soft black eyes makes them amusing little creatures to watch.

Nest.-A hollow in the sand without linings; but when marshy ground is selected Mr. Nelson says that the nest is lined with a few grass stems. Sometimes the eggs are laid on the bare rock just beyond the reach of the waves.

Egrgs.-Two or three in number, the former being the usual complement, according to my correspondent, Mr. Robert Read. They are rather smaller than those of the Common Tern, and present more variations in colour. While many have the characteristic spots and blotches of a similar aspect to that of the eggs of Sterna fluviatilis, there is, in a general sense, a distinctly more spotted appearance. Axis, $\mathrm{I}^{\circ} 4^{-\mathrm{I}^{*} 7}$ inch: diam., $I \cdot I-I^{\cdot} \cdot 2$.

III. THE ROSEATE TERN. STERNA DOUGALLI.

Sterna dougalli, Mont. Orn. Dict. Suppl. (1813); Dresser, B. Eur. viii. p. 273 , pl. $5^{81}(1876)$; B. O. U. List Brit. B. p. I 8 I (I883); Saunders, ed. Yarrell's Brit. B. iii. p. 544 (1884) ; Seebohm, Hist. Brit. B. iii. p. 277 (I885); Saunders, Man. Brit. B. p. 629 (1889); Lilford, Col. Fig. Brit. B. part xxviii. (1894); Saunders, Cat. B. Brit. Mus, xxv. p. $70(1896)$. 
Sterna masdougalli, Macgill. Brit. B. v. p. 648 ( $\left.185^{2}\right)$.

\section{(Plate XCVII.)}

Adult Male-General colour above delicate pearly-grey, slightly paler on the rump and upper tail-coverts and inner secondaries, which are margined with white at the ends; wingcoverts like the back, as also the bastard-wing and primarycoverts; quills pearly-grey, the primaries edged on the inner web and the secondaries on the outer web, with white; quills pearly-grey, darker on the inner webs, which have rather broad borders of white; the three outer primaries with white shafts, emphasized on the first by a blackish outer web, and along the inner edge of the white shaft by a line of blackish, becoming dark grey towards the end of the feathers; the second and third primaries with a dark grey and broader line along the inner length of the shaft, but the outer web frosted with pearlygrey; all the other primaries white-shafted, with darker grey on the inner web, broader but not inclining to blackish; secondaries pearly-grey, with white tips and a good deal of white on the inner web; tail-feathers pearly-grey, almost white, the long outer feathers nearly entirely white; crown of head and nape black, with a very distinct pointed crest ; hind-neck, sides of face, and under surface of the body white, with a beautiful rosy blush, which disappears in time; the line of black and white on the sides of the head very sharply defined, and extending across the lower half of the lores, below the eye, above the ear-coverts; "bill orange at the base, the anterior part from the angle black; tarsi and toes orange-red; by the end of May, in the northern hemisphere, the amount of black on the bill has largely increased" (Saunders). Total length, ${ }_{3} \cdot 7$ inches; culmen, I 45 ; wing, 8.8 ; tail, 5.9 ; tarsus, 0.85 .

Adult Female.-Similar to the male. Total length, I3.I inches; wing, $8 \cdot 5$.

Adult in Winter Plumage. - Similar to the summer plumage, but differing in the forehead being spotted with white, the under parts nearly white, with little pink tint; bill nearly black (Saunders).

Young.--Differs from the adult in being mottied with a black sub-terminal bar to the feathers of the upper surface, quills, 


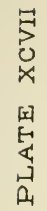

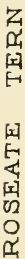

$4 k$
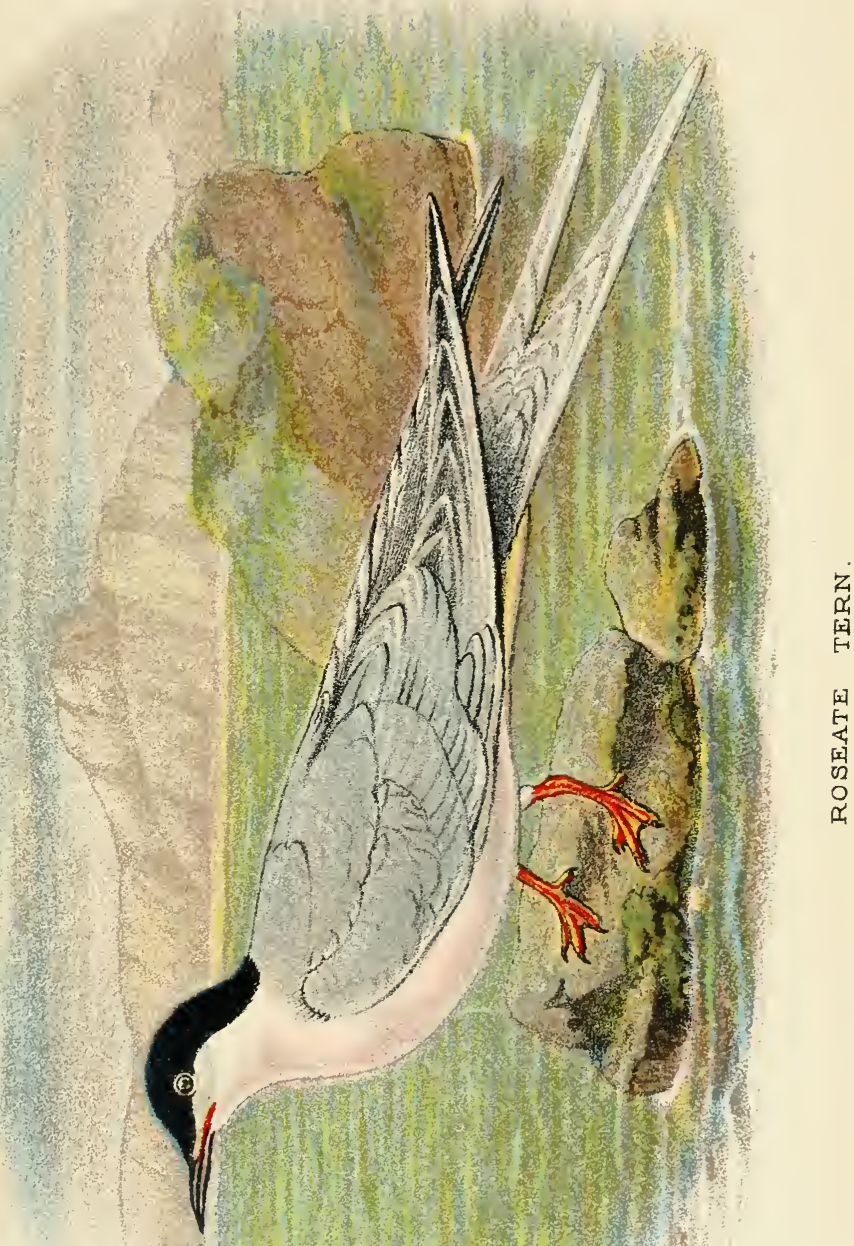

and tail-feathers; a distinct white collar round the hind-neck ; the crown of the head and nape blackish streaked with white, the forehead whiter and streaked with black; lores and sides of hinder crown blackish; marginal lesser wing-coverts black, forming a bar; "bill black; feet grey; iris black" ( $D r$. Coppinger).

Young in First Winter Plumage.-Grey above like the adult in winter plumage, but distinguished by the dark band along the marginal upper wing coverts; the head and nape black, the forehead white.

-Characters.-The Roseate Tern may be recognised from the two preceding species by its long and slender bill, which is orange at the base and black at the end, but more especially by the inner webs of the primaries being white to the tips.

Range in Great Britain.-The present species formerly bred in small colonies in various places off the coasts of the British Isles. The best-known breeding ground of the Roseate Tern was the Farne Islands, but on the west coast Foulney and Walney Islands were both resorts for the species, as well as some of the Scilly Islands. The late Mr. Henry Seebohm, however, believed that the species was practically extinct in the British Islands, but under the protective measures now adopted at the Farnes and elsewhere, the species has resumed its nesting in some of its old haunts.

I have, moreover, received the following interesting note from Mr. J. T. Proud, of Bishop Auckland:- "I am glad to say that I know of a nice little colony of Roseate Terns breeding with the Common and Arctic Terns, in Wales. I have this year $(1896)$ spent considerable time in making sure of the correct identification of the eggs. I found by marking the nests and watching the birds on to them, that the eggs (nez'er more than two in number) were quite different from those of the Arctic and Common Terns, and having once niade sure of the difference, there was no mistaking them." *

Mr. R. J. Ussher says that, in Ireland, the species formerly bred on islands off the coasts of Down, Dublin, and Wexford.

* Mr Proud very kindly s nt up the eggs and the bird, which I banded over to Mr. Suunders, and he exhibited them at the meting of the B.O. Club on the 2oth of January, I $\$ 97$. 
Range Outside the British Islands. - The Roseate Tern is a maritime species, and is found on most of the coasts of the temperate and tropical portions of the Old and New Worlds. In many of its southern habitats it is only known as a winter visitor, but it also breeds in several of its tropical resorts, such, for instance, being Ceylon, the Andaman Islands, New Caledonia, and the West Indies. It does not range north of $57^{\circ} \mathrm{N}$. lat., being, as Mr. Saunders remarks, "merely a straggler to the coasts of the North Sea. It has several colonies on the west side of France, and a few examples have been obtained in the Mediterranean; while we trace it to the Azores and across the Atlantic-by way of the Bermudas-to America. There it is found breeding along the east coast from New England to Honduras, and throughout the West Indies, though it has not yet been obtained on the Pacific sea-board." In winter it visits South Africa, the Indian and Australian oceans, and breeds in Northern Australia. Specimens from southern localities are often found in full breeding plumage, and we may expect that more nesting-places of the species will yet be discovered.

Habits.-The Roseate Tern is so called on account of the beautiful rosy blush which is seen over the white under parts, a feature which, unfortunately, disappears gradually in preserved specimens, though traces may still be seen in skins which have been in cabinets for years. There is little to say about its habits, which are like those of other Terns, except that it is more exclusively a maritime species than the Arctic or Common Terns. Its note is said to be a somewhat harsh "crake."

Nest.-As with other Terns, there is generally no real nest, a slight hollow in the sand being made for the reception of the eggs, though occasionally a few bits of dried grass form the scanty lining.

Eggs.-Mr. Proud tells me that the eggs are invariably two in number. Seebohm says two or three are found, and $\mathrm{Mr}$. Howard Saunders records instances of four being met with, probably the produce of two females. In general colour the eggs of the Roseate Tern resemble those of the Common Tern, but they are somewhat more elongated, and the markings are smaller and more scattered, the grey underlying markings 
being often very distinct. In one specimen in the British Museum the ground-colour is purplish-buff with brown spots. Axis, $\mathrm{I} \cdot 55^{-\mathrm{r}} \cdot 85^{2}$ inch; diam. $1 \cdot \circ 5^{-\mathrm{I}} \cdot 2$.

IV. THE SANDWICH TERN.

STERNA CANTIACA.

Sterna cantiaca, Gm. Syst. Nat. i. p. 606 ( 1788 ); Macgill. Brit. B. v. p. 630 ( $\left.185^{2}\right)$; Dresser, B. Eur. viii. p. $30 \mathrm{I}$, pl. 586 (1877); B. O. U. List Brit. B. p. I83 (I883); Saunders, ed. Yarrell's Brit. B. iii. p. 540 (1884); Seebohm, Hist. Brit. B. iii. p. 272 (1885); Saunders, Man. Brit. B. p. 627 (1889); Lilford, Col. Fig. Brit. B. part xxix. (1894); Saunders, Cat. B. Brit. Mus. xxv. p. 75 (I896.)

Adult Male.-General colour above dark pearly-grey, the scapulars tipped with white; wing-coverts like the back, with the bend of the wing white ; bastard-wing, primary-coverts, and quills darker pearly-grey, especially the primaries, which are frosted externally with dark grey ; the four outer primaries with white shaft, accompanied by a blackish band along its inner aspect to the end of the feathers, the rest of the inner webs white; inner primaries and secondaries white, with more or less grey on the outer webs; upper tail-coverts and tail white; crown of head and nape blue-black, the crest-feathers pointed ; the lower half of the lores, sides of face, sides of neck and a collar round the hind neck, as well as the under surface of the body with the under wing-coverts and axillaries, pure white. Total length, 16.5 inches; culmen, 2.3 ; wing, II $\cdot 8$; tail, 6.5 ; tarsus, $\mathrm{I} \cdot \mathrm{I}$.

Adult Female.-Similar to the male. Total length, I6.5 inches ; wing, $12^{\circ} \circ$.

Adult in winter.-Differs from the summer plumage in wanting the black head, the forehead being white, with a black spot in front of the eye; the crown white, with a few narrow black streaks, and the nape more thickly streaked with black.

Young.--Mottled all over with sub-marginal or sub-terminal bars of black; along the lesser wing-coverts a band of ashygrey; tail-feathers dusky at tips and barred or spotted with black; bill horn-coloured, yellowish at the base of the under mandible. 
Nestling.-Clothed in greyish down with a sandy-buff tinge, the head somewhat white, and all the upper parts mottled with dusky blackish, very indistinctly; below white; bill yellowish ; feet greyish-brown, the webs paler.

Characters.-The Sandwich Tern is the largest of our indigenous Terns, the wings exceeding twelve inches in length. The feet are black, and the bill is black with a yellow tip. The feathers of the nape are pointed and form an elongated crest.

Range in the British Islands.-This species is a summer visitor to Great Britain, and still breeds regularly on the Farne Islands as well as in a few other localities in England and Scotland, on both the east and west coasts. In several places, such as the Scilly Islands, where the species was formerly known to breed, it is no longer seen during the nesting season. Mr. Ussher says that in Ireland it is "only known to breed at the present day on one small lake near Ballina, in Mayo, where it is strictly preserved. It has disappeared from its former breeding place on the Rockabill, Co. Dublin."

Range outside the British Islands.-The following extract from Mr. Saunders' recent volume on the Laride gives the range of the Sandwich Tern with a preciseness which leaves me nothing to improve upon:- "Atlantic and North Sea coasts from the Orkneys southwards to the Mediteranean Black Sea, and Caspian (breeding) ; in winter, along the west coast of Africa to the Cape of Good Hope and up to Natal, down the Red Sea, and across Mesopotamia to the Persian Gulf, Mekran coast, and Karachi. East side of America from southern New England to British Honduras, not breeding to the northward of Florida; only found on the Pacific side on the coast of Guatemala and vicinity, where the continent is very narrow."

Fabits.-Seehohm thus describes a visit to the Farne Islands in 1870 , when the Sandwich Terns were nesting in some numbers:- "On a gently sloping sand-bank leading up to the centre of the island, which was merely a mass of shelving rock perhaps thirty feet across, there was a large colony of the Sandwich Tern. In the thick of them there must lave been 
on an average a nest per square yard. 'The birds, which were not then sitting (it was the 3 rd of June), soon discovered that their colony was being invaded, and flew in hundreds over us for a short time." Besides taking the eggs of other species, such as Eider Ducks, Gulls, \&c., he states that he saw more than two hundred eggs of the Sandwich Tern. "In the year when I found them in still greater abundance, they had chosen the same locality for their colony; but they were so much molested that they soon deserted the place and moved their quarters to the grasscovered island adjoining, where their eggs where in such profusion that we inadvertently trod on many of them. In this locality many of the birds had arranged the scattered bits of dead weed which were lying about into the semblance of a nest. In addition to the Arr-ee, which seems, in a more or less modified form, to be common to all the Terns, the Sandwich Tern has a note which may be represented by the syllables skerr-rek. The nesting season in the Farnes begins about the middle of May."

Nest.-This is described by Seebohm as merely a slight hollow in the bare sand, in diameter and depth of the dimensions of a cheese-plate, and he says that the nests and eggs were very difficult to distinguish from the sand and fine gravel by which they were surrounded. The nests are, however, sometimes more substantial structures of bents.

Eggs.--Two or three in number, rarely the latter. They are very handsome and vary to any extent. The ground-colour is generally clay-coloured or ochreous-buff, deeper or lighter in shade, the spots and markings being black or dark brown, often with the purplish-grey underlying spots very distinct and quite as plain as the overlying spots and blotches. In many examples the spots and scribblings of black are distributed over the whole egg, while others are remarkable for their bold confluent blotches. Axis, $2^{\circ} 0-2 \cdot 25$ inches; diam., I.55-I'5.

V. THE SMALLEK SOOTY TERN. STERNA AN ESTHETA.

Sterna anastheta, Scop. Del. Flor. et. Faun. Insubr. i. p. 92, no. 72 (1786); Saunders, ed. Yarrell's Brit. B. iii. p. $5^{6} 5$; note (1884); id. Cat. B. Brit. Mus. xxv. p. IoI (I895.) 
Adult Male.-General colour above sooty-brown, shaded with ashy-grey; the mantle conspicuously greyer than the back; wing-coverts like the back; bastard-wing, primary-coverts, and quills black, the primaries with brown shafts and a long "wedge" of white on the inner web, gradually diminishing in size on the inner primaries; upper tail-coverts and tail-feathers brown, shaded with ashy-grey; the outermost tail-feather white, the next white for two-thirds of its length and brown for the terminal third; the next feather white for nearly half its length and brown for the terminal half; the white on the central feathers becoming gradually reduced in size and confined to the inner web; crown of head and nape black, with a white frontal band extending backwards in a broad streak over the eye; a black streak across the lores from the base of the bill to the eye; cheeks, earcoverts, and entire under surface of body white, including the under wing-coverts and axillaries; "bill, tarsi, and feet black, the inner webs of the latter considerably excised" (Saunders). Total length, $\mathrm{I}_{5}$ inches; culmen, $\mathrm{I}^{\circ} 55$; wing, $\mathrm{10}^{\circ} \mathrm{O}^{\circ}$; tail, 6.6 ; tarsus, $0^{\circ} 9$.

Adult Female.-Similar to the male. Total length, 15 inches; wings, $10^{\circ} 4$.

Adult in Winter Plumage.-Similar to the summer plumage, but with the lores and crown mottled with white for a short time. (Saunders.)

Young.--Sooty-brown above, the head mottled obscurely with dull rufous, with which colour the feathers of the upper surface are edged; these rufous margins gradually fading to white and ultimately becoming abraded; under surface of body light dove-grey, whiter on the face and throat; under wingcoverts white with a grey shade.

Young in First Winter Plumage.-Rather more ashy than the adults, and with conspicuous white or ashy-white margins to the feathers of the back; the mantle hoary-whitish ; forehead and crown white, the hinder crown broadly streaked with black; the nape and hind neck entirely black; wing-coverts brown, the marginal ones black, forming a band. Mr. Saunders says that full plumage is not attained till the bird is at least two years old. 
Characters.-This species is easily recognised from all the other British Terns, except $S$. fuliginosa, by its white forehead and black streak across the lores. 'The upper surface is sootyblack, including the rump, and the mantle is lighter, umberbrown or ashy-grey, contrasting with the black head. So different in style of plumage are the Sooty Terns that they have been placed by many authors in a separate genus-Haliplanaand the uniform sooty colour of the young bird, only relieved by white or rufous tips to the feathers, is quite peculiar among the true Terns. Notwithstanding these differences, however, Mr. Saunders has come to the conclusion that the Sooty Terns cannot be separated structurally and generically from Sterna.

Range in Great Britain.-The present species has occurred in England only on one occasion, when a specimen was captured in September, 1875 , on one of the lightships at the mouth of the Thames. The evidence of the occurrence of this example, which is now in the collection of Mr. Edward Bidwell, appears to be fairly conclusive, as is admitted by Mr. Saunders, who has himself investigated the circumstances.

Range Outside the British Islands.-The following is the distribution allotted to the species by Mr. Saunders in the "Catalogue of Birds":- "Inter-tropical and juxta-tropical seas-Gulf of Mexico and West Indies; West Africa, Lower Red Sea, East Africa, Madagascar, and Mascarene Islands and Indian Ocean generally; Moluccas, China Sea up to Japan, Pelew Islands, New Guinea, Northern Australia, the Fiji, Tonga, Ellice, and Phonix groups. In the Low Islands and the Sandwich Islands the representative species appears to be S. lunata."

Habits.-'These are doubtless similar to those of the Sooty Tern in many respects, but Gilbert remarks that on Houtmann's Abrolhos in Western Australia, he found it breeding, and that the species differed from its allies, "inasmuch as, instead of being gregarious, each pair remains solitary, and its single egg is deposited in the fissure of a rock close to the water's edge without any nest or flooring."

Nest.-None, the single egg being deposited in the holes of the loose friable coral sandstone, according to Macgillivray, who rict with the species on the islands of Torres Straits. 
Eggs.-Ground-colour varying from whitish stone-colour to clay-brown, the markings being reddish-brown or black, and varying in character from small spots, streaks, and lines or scratches, to larger spots or small blotches, never confluent, and equally distributed over the surface of the egg ; the underlying spots of purplish-grey distinctly indicated, but seldom equalling the overlying markings in prominence. Axis, I $75^{-}$ I.95 inch; diam. I'25-I'35.

\section{V1. THE SOOTY TERN. STERNA FULIGINOSA.}

Sterna fuliginosa, Gm. Syst. Nat. i. p. 605 ( т 78 ) ; Dresser, B. Eur. viii. p. 307 , pl. $5^{87}(\mathrm{I} 877)$; B. O. U. List Brit. B. p. $18_{3}\left(\mathbf{I} 88_{3}\right)$; Saunders, ed. Yarrell's Brit. B. iii. p. 562 (I884); Seebohm, Hist. Brit. B. iii. p. 26,2 (I885); Saunders, Man. Brit. B. p. 637 (1889); id. Cat. B. Brit. Mus. xxv. p. 106 ( 1896 ).

Adult Male.-Similar to $S$. ancestheta, but more uniformly sooty-black above, the light mantle not being emphasized, and thus the black crown is scarcely darker than the remainder of the upper surface; the quills blackish, with a dark ashy "wedge" on the inner web of the primaries, not white as in S. ancestheta ; "bill and feet black, with a slightly reddish tinge" (Saunders). Total length, I4.5 inches; culmen, I.65; wing, I I.० ; tail, $5^{\circ} 8$; tarsus, 0.85 .

Adult Female.-Similar to the male. Total length, I 5.5 inches; wing, I I 6 .

Adult in Winter Plumage--Only distinguishable from the summer plumage by having white flecks on the lores and crown (Saunders).

Nestling.-Mottled above with dusky-blackish and sandybuff, intermixed with a good deal of white on the back and rump; under surface of body whitish, the cheeks and sides of the face like the back. As the young bird increases in size, the down is replaced by blackish feathers which have sandyrufous or white tips, those on the scapular-plumes being conspicuously white. The under surface of the body is white, but the sides of the face are like the crown and are similarly mottled. 
Young Birds.-The fully-grown young in its first plumage is sooty-brown above and below, the under surface being, perhaps, a trifle paler, and the lower abdomen white; the feathers of the back, wing-coverts, secondaries, and tail-feathers tipped with a bar of sandy-rufous, which soon bleaches to white.

Characters.-As in the preceding species, the dark colour of the upper parts is the chief characteristic. It is a larger bird than $S$. ancestheta, with a longer wing; and it is further distinguished from that species by having the web between the middle and inner toe nearly full, and far less excised than in S. ancestheta.

Range in Great Britain.-Only three occurrences of the present species in England appear to be beyond dispute, as Mr. Saunders says that most of the examples identified as Sooty Terns have turned out to be Black Terns. One specimen was procured at Tutbury, near Burton-on-'Trent, in October, $\mathrm{I}_{52}$; another near Wallingford, in Eerkshire, on the 2 Ist of June, I869; and another near Bath on the 4 th of October, 1885.

Range outside the British Islands._- "Tropical and juxta-tropical seas, wherever suitable islands and reefs exist; occasionally wandering to Maine in North America and to Europe. Almost unknown on the South American side of the Pacific; otherwise very generally distributed" (H. Saunders).

Habits.-The enormous quantities of this Tern which frequent certain isolated breeding-places of sea-birds, such, for instance, as the volcanic island of Ascension, have often been written about, and a description of "Wide-awake Fair," as the assemblage of Terns is called on that island, has more than once been published. Two hundred dozen of eggs have been collected on Ascension in a single morning. Macgillivray, too, speaks of the enormous numbers which he found breeding on Raine's Islet in Torres Straits. He writes:- "During the month of June, I844, about I, 500 dozen of eggs were procured by the party on the island. About the 2 oth of June nearly one-half of the young birds (hatched twenty-five or thirty days previously) were able to fly, and many were quite strong on the wing. Great numbers of young birds unable to fly were killed for the pot; in one mess of twenty-two men the average 
number consumed daily in June was fifty; and supposing the convicts (twenty in number) to have consumed as many, 3,000 young birds must have been killed in one month; yet I could observe no sensible diminution in the number of young, a circumstance which will give the reader some idea of the vast number of birds of this species congregated on a mere vegetated sand-bank like Raine's Islet."

A similar gathering of these Terns during the nesting-season has been described and figured by the Hon. Walter Rothschild in his "Avifauna of Laysan."

Nest.-None, the egg being deposited in the sand or among the fissures of the volcanic débris of an island such as Ascension.

Egg.-One only. Compared with the eggs of S. anastheta, the markings, though very similar in character, are, as a rule, bolder, and the ground-colour approaches in some specimens to a purplish-buff. Axis, $\mathrm{I}^{\circ} 95^{-2} \cdot{ }^{\prime} 5$ inches; diam., $\mathrm{I} \cdot 35^{-1} \cdot 55$.

VII. THE LITTLE 'TERN. STERNA MINUTA.

Sterna minuta, Linn. Syst. Nat. i. p. 228 ( I 766) ; Macgill. Brit. B. v. p. $65_{2}\left(185_{2}\right)$; Dresser, B. Eur. viii. p. 279 , pl. 582 (1876); B. O. U. List Brit. B. p. I8I (I883); Saunders, ed. Yarrell's Brit. B. iii. p. $55^{8}$ (1884); Seebohm, Hist. Brit. B. iii. p. 289 (1885) ; Saunders, Man. Brit. B. p. 635 (1889); Lilford, Col. Fig. Brit. B. part xxix. (I 894); Saunders, Cat. B. Brit. Mus. xxv. p. I 16 (1896).

Adult Male--General colour above pearly-grey, the wingcoverts like the back; lower rump and upper tail-coverts white ; bastard-wing pearly-grey, but the primary-coverts blackish like the primaries, the first three of which are blackish along the outer web and also along the inner side of the shaft for the whole length of the quill, broadening on the second and third primary, all three of them having the rest of the inner web white; remainder of the primaries pearly-grey, a little darker than the back, and with white margins to the innermost; secondaries mostly white, the outer web and the shaft dusky-grey; the innermost secondaries pearly-grey like the 
back; tail-feathers white; forehead and feathers above the eye white; crown of head and nape black, as also a line through the eye and the lores; cheeks, sides of face, and under surface of body pure silky white; "bill gamboge-yellow, tipped with black; tarsi and feet orange-yellow" (II. Saunders). Total length, 9.5 inches; culmen, 1.3 ; wing, 6.8 ; tail, 3.4 ; tarsus, $0^{\circ} 6$.

Adult Female.-Similar to the male, but with the outer tailfeathers scarcely so developed. Total length, $9^{\circ} \circ$ inches; wing, 6.8 .

Adult in Winter Plumage.-Similar to the summer plumage, but with more white on the forehead, and with the outer primaries rather darker towards their ends.

Young Birds.-These are easily distinguished by the black mottling on the feathers of the upper surface, which takes the form of circular bars or arrow-headed sub-terminal bars, all the feathers being tinged or edged with sandy-buff; the rump light pearly-grey, with a shade of the latter colour over the upper tail-coverts and tail-feathers; wing-coverts mottled like the back, with a dark-grey band along the marginal lesser wingcoverts ; forehead sullied white, the crown sandy-buff streaked with black, the hinder crown and nape entirely blackish ; a loral streak of dusky black; bill blackish, with a slight reddish tinge.

The sandy colour of the upper surface in the young bird quickly disappears, but the black bars are maintained till the autumn moult.

Nestling.-Light sandy-buff, spotted and streaked with black; under surface whitish, the throat sandy-buff, with the region of the gape dusky.

Range in Great Britain.-The Little Tern is found nesting in scattered colonies on most of the coasts of the British Islands, though many localities in the north of England and in Scotland, where the species formerly bred, know it no more. It arrives from the south early in May, and leaves in September or in the first weeks of October. Mr. Ussher says that in Ireland it breeds on sea-beaches in Donegal, Dublin, Wicklow, Wexford, Galway, and Mayo, but in much smaller numbers than the Common or Arctic Terns. 
Range outside the Eritish Islands. - The species extends to about $60^{\circ}$ N. lat. in Europe, is scarce on the northern shores of the Baltic, and, as Mr. Howard Saunders says, is "rare on the southern shore of that sea, following the course of the large rivers for so great a distance-nesting on their islands and sand-banksthat it may be said to extend across the Continent to the Mediterranean, Black, and Caspian Seas, while it also frequents the Atlantic coast." Eastward it ranges to Transcaspia, Turkestan, and Northern India, breeding in all these localities. In winter it ranges along the coast of West Africa to the Cape of Good Hope, and is found at the same season along the Burmese coasts as far south as the island of Java. The place of the Little Tern is taken by Sterna saundersi in the Indian Ocean, the Persian Gulf, Red Sea, and along the coast of East Africa to Natal and the Mascarene Islands.

Habits.-The Little Tern is one of a group of small species, distributed over the greater part of the Old World, as well as temperate and tropical North America. From their small size and different appearance to the ordinary Terns they have often been separated from the latter as a distinct genus Stermula, but Mr. Saunders finds no characters for their generic separation from the members of the genus Sterna.

Nevertheless, any one who has seen the birds on the shore, recognises at once a certain difference in the appearance and ways of the Little Tern from those of its larger and more conspicuous colleagues. This may be due, however, rather to the smaller size of $S$. minuta, and its quicker motions, than to any real difference in the habits of this small Tern, as, after all, the ways of the species of the genus Sterna are very much alike. Naturally the small size of the present bird renders it less conspicuous than the Common Tern, and whereas the colonies of the latter bird can generally be detectcd from some distance, the Little Terns are only discovered by a sudden invasion of their nesting-places. 'The pairs keep together, and may generally be seen sitting side by side, though they do not permit of a near approach, but fly off before the intruder comes within gun-shot. Only when they have young, however, are they more verituresome, and fly much nearer to the enemy. Such, at least, is my experience, though other 
observers have found the bird quite bold, so much so that it has been known to settle down on its nest within sight of the intruder.

Nest.-Mr. Robert Read tells me that in the south-east of England he has never found any attempt at a nest, the eggs being laid on the bare sand. Thus, too, I have found them myself; but on the east coast of Scotland, Mr. Read says that he has found some very pretty nests, consisting of a cupshaped hollow scooped out of the sand, and surrounded by a ring of broken cockle-shells and other shells of various colours.

Eggs.-Generally two, but sometimes three in number, varying to a remarkable extent in tint of ground-colour, from greyish stone-colour to buff or clay-brown of different shades. The markings are generally distributed over the whole surface of the egg, and are, as a rule, scattered spots of deep reddishbrown or black, occasionally confluent and forming a blotch, but it is very seldom that large blotches are seen. The underlying grey spots are always more or less in evidence. Axis, $\mathrm{I}^{\circ} 25^{-1} \cdot 4$ inch; diam. $0^{\circ} 9-\mathrm{I}^{\circ} \mathrm{O}$.

\section{THE NODDY TERNS. GENUS ANOUS.}

Anous, Steph. in Shaw's Gen. Zool. xiii. part i. p. I39 (1826).

$$
\text { Type } A \text {. stolidus (L.). }
$$

The Noddies are remarkable for their sombre plumage. The tail is graduated, and the outer pair of tail-feathers are shorter than the next pair, the fourth pair from the outside being the longest. The toes are short, and the middle toe and claw do not equal the culmen in length. The bill is strong and decurved at the tip, and the distance from the angle of the genys to the tip is less than the distance from this angle to the gape. (Cf. Saunders, Cat. B. Brit. Mus. xxv. p. 5.)

\section{THE NODDY TERN. ANOUS STOLIDUS.}

Sterna stolida, Linn. Syst. Nat. i. p. 227 ( 1766 ); Seebohm, Hist. Brit. B. iii. p. 294 (1885).

Megalopterus stolidus, Macgill. Brit. B. v. p. 672 (1852). 
Anous stolidus, B. O. U. List, Brit. B. p. I86 (1883) ; Saunders, ed. Yarrell's Brit. B. iii. p. $5^{67}$ (1884); id. Man. Brit. B. p. 639 (1889); Lilford, Col. Fig. Brit. B. part xxix. (1894); Saunders, Cat. B. Brit. Mus. xxv. p. г 36 (1 896 ).

Adult Male in Breeding Plumage.-General colour above dark chocolate-brown, rather darker on the rump and upper tailcoverts ; wing-coverts like the back ; primary-coverts and quills blackish, the inner secondaries chocolate-brown like the back; tail-feathers blackish; forehead white, extending in a narrow line above the eye; rest of the crown pearly-grey, slightly darker on the nape and hind neck; lores and feathers round the eye leaden-black; eyelid white; remainder of sides of face and under surface of body chocolate-brown, with a shade of grey perceptible on the sides of the face and throat, as well as on the under wing-coverts; "bill blackish; tarsi and feet reddish-brown, fully webbed, the webs ochraceous" ( $H$. Saunders). Total length, ${ }^{1} 4.5$ inches; culmen, $\mathbf{I}^{\circ} \mathbf{2}$; wing, I I. I ; tail, $5^{\circ} 6$; tarsus, I.05.

Adult Female.-Similar to the male, but slightly smaller, with a weaker bill, and, as a rule, somewhat browner on the shoulders and with less lead-colour on the throat. Total length, $14^{\circ} 5$ inches; wing, $10^{\circ} 5$.

Young.-Browner than the adults and rather paler; forehead and crown greyish-brown, with a narrow white superciliary line, conspicuous by contrast against the blackish lores. A fledgeling from Ascension Island is umber-brown above and below, with the whitish streak above the lores very marked and continuous round the base of the bill, and with a slight greyish tint on the forehead. A downy nestling about five days old, from British Honduras, has the forehead and crown dull white, the lores blackish ; the upper surface mouse-brown; the nape and the throat darkest, with the lower parts paler; another, only just hatched is nearly uniform sooty-brown (Saunders).

Range in Great Britain.-The only examples of the Noddy recorded from the British Islands, or, for that matter, from any part of Europe, are two specimens obtained in Ireland, off the coast of Wexford, between the Tuskar Lighthouse and the Bay 
of Dublin, about the year $\mathrm{I}_{3} \mathrm{O}$. One of them is still preserved in the Dublin Museum.

Range outside the British Islands.-The following summary of the distribution of the Noddy is given by Mr. Saunders in the British Museum "Catalogue of Birds": - "Tropical and juxta-tropical America, chiefly on the Atlantic side, but also on the Pacific, in Mexico and the central region; Atlantic down to Tristan da Cunha (breeding); inter-tropical African and Asian seas, up to Yeddo; Australasia down to about $35^{\circ}$ S. ; islands of the Pacific up to Laysan, \&c., and as far as Sala y Gomez, $105^{\circ}$ W.; also Chatham Island, Galapagos (fide Ridgway), but not on the coasts of Peru or Chile. Breeding, as a rule, where found."

Habits.-The Noddies nest in enormous numbers in some of the islands of the Southern Ocean, generally in the vicinity of the Sooty Tern ( $S$. fuliginosa) with which the Noddy is always on good terms. The birds are generally so tame as to be with difficulty removed from their nests, but Mr. Palmer says that he has known them boldly drive away Albatroses. Gilbert gives a good account of the nesting of the Noddy on Houtman's Abrolhos off Western Australia, and he declares that the increase in the number of the Terns would be overwhelming but for the check which nature has provided against it in the shape of a lizard, which is extremely abundant about their breeding-places, finding an easy prey in the Noddy and Sooty 'Terns. "I am satisfied," he writes, "from constant observation, that, on an average, not more than one out of every twenty birds hatched ever reaches maturity or lives long enough to take wing; besides this, great numbers of the old birds are constantly killed. These lizards do not eat the whole bird, but merely extract the brains and vertebral marrow; the remainder, however, is soon cleared off by the Dermestes lardarius, a beetle which is here in amazing numbers, and gave me a great deal of uneasiness and constant trouble to preserve my collection from its repeated attacks." The food of the Noddy is said by Gilbert "to consist of small fish, small mollusca, medusæ, cuttle-fish, \&c."

Nest.-Made of sea-weed, according to Gilbert ; about six inches in diameter, and varying in height from four to eight 
inches, but without anything like regularity of form ; the top is nearly flat, there being but a very slight hollow to prevent the egg rolling off. The nests are so completely plastered with the excrement of the birds, that at first sight it appears to be almost the only material ; they are either placed on the ground, in a clear open space, or on the tops of the thick scrub, over those of $S$. fuliginosa. These two species, the Noddy and the Sooty Tern, incubate together in the utmost harmony, the bushes to an immense extent wearing a mottled appearance from the great mass of birds of both species perched on the top, the male Sooty Tern sitting quite close to the nest of the Noddy, whilst its mate is beneath, performing her arduous duties of incubation. (Cf. Gould's Handb. B. Austr. ii. p. 4 I 3). Sometimes no nest is made and the egg is placed in a crevice of rock or coral-reef.

Eggs.-One only, according to the observations of all recent observers. Audubon gives the number as three. They are similar to those of the Sooty Tern, and of the same character, but they are always much paler and never exceed a light stone-colour, the spotting being much more sparsely distributed and smaller; the type with scratches or zig-zag markings appears to be absent. On the other hand, there are one or two eggs in the British Museum which have distinct blotches, confluent at the larger end, and in one example, the large end of the egg is taken up by an immense patch of reddish-brown. Axis, $2 \cdot 05^{-2} \cdot 5_{5}$ inches; diam. I*4-I'55.

Mr. Saunders points out that the yolk of the Noddy's egg is yellow, while that of the Sooty Tern is deep orangered. The Hon. Walter Rothschild also calls attention to the fact that the inside of the Noddy's egg is darker and more green when held up to the light.

\section{THE GULLS. SUB-FAMILY LARINA.}

In the Gulls, the bill is what is called "epignathous," the upper mandible being longer and bent down over the tip of the lower one; tail usually square, seldom forked, exceptionally cuneate. (Cf. Saunders, Cat. B. Brit. Mus. xxv. p. $4(\mathrm{I} 895)$.) 


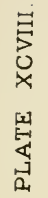

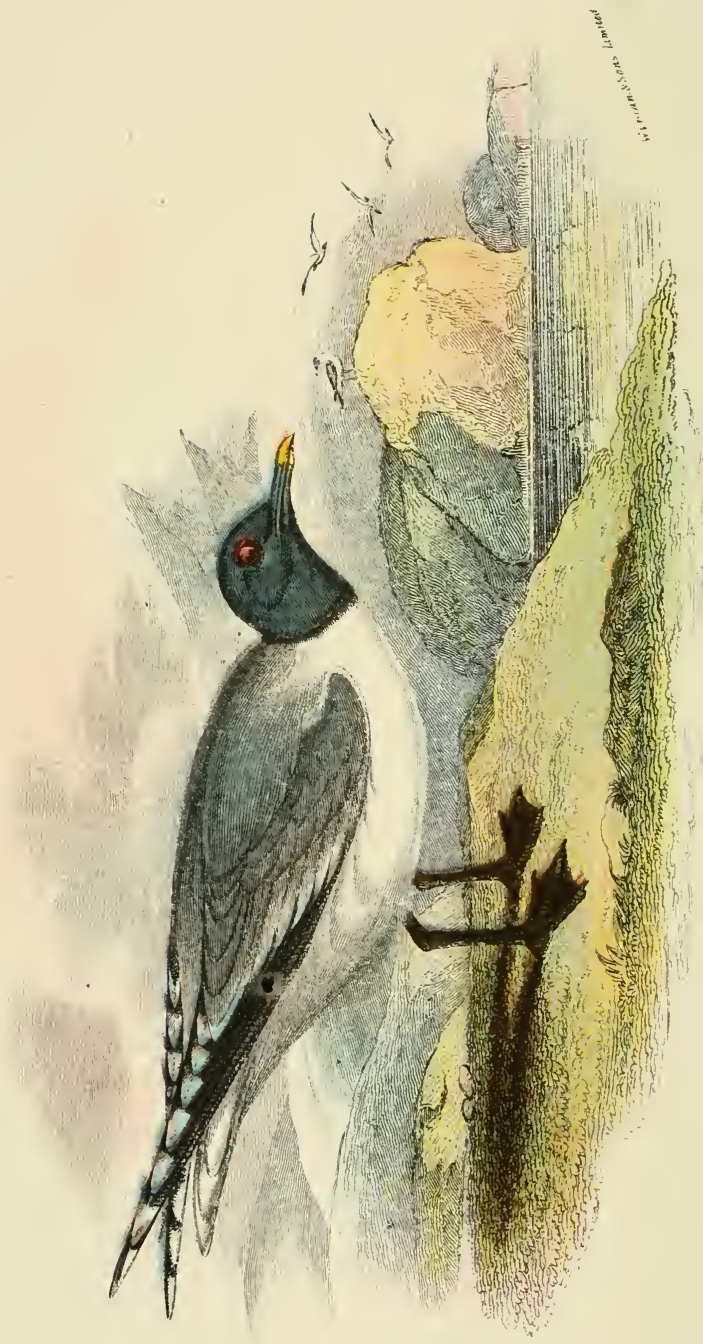

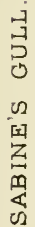


TIIE FORK-TAILED GULLS. GENUS XEMA.

Xema, Leach in J. Ross's Voy. Baffin's Bay, App. ii. p. 57 (1819).

Type $X$. sabinii (J. Sabine).

In this genus the tail is considerably forked, and the wings long, the hind-toe being free and very small.

Only two species of Fork-tailed Gull are known, the Arctic $X$. sabinii, and $X$. furcata of the Galapagos Islands, which seems to wander down the Pacific coast of South America, as it has been found at Paracas Bay, in Peru.

\section{SAIINE'S GULl. Xema SABiniI.}

Larus sabinii, J. Sabine, Trans. Linn. Soc. xii. p. 520, pl. 29 (1818); Seebohm, Hist. Brit. B. iii. p. 298 (1885); Lilford, Col. Fig. Brit. B. part xx. (I89I).

Gavia sabinii, Macgill. Brit. B. v. p. 607 (1852.)

Xema sabinii, Dresser, B. Eur. viii. p. 337 , pl. 593 (1874);

B. O. U. List. Brit. B. p. I93 (I883); Saunders ed. Yarrell's Brit. B. iii. p. 573 ( 1884 ); id. Man. Brit. B. p. 64I (I889); id. Cat. B. Mus. xxv. p. I62 (I896).

\section{(Plate XCVIII.)}

Adult Mrale in Breeding Plumage.-General colour above light ashy-grey, including the wing-coverts and inner secondaries, the latter as well as the greater wing-coverts being tipped with white, the latter very broadly, so that nearly the terminal half of the external greater wing-coverts is white; exterior lesser coverts, bastard-wing, primary-coverts, and primaries black, the latter tipped with white, and having the inner half of the inner web longitudinally white, but this not reaching to the end of the quill on the first five primaries; the black much diminished on the next two primaries, the inner primaries and the secondaries being white; the innermost secondaries light ashy-grey, white at their ends ; lower rump, upper tail-coverts, and tail white, the latter conspicuously forked; head, sides of face, and throat dark slaty-grey; the hind-neck, sides of neck, and under surface of body, from the lower throat downwards, 
pure white; the slaty-grey head being separated from the white neck and chest by a band of black; bill black to the angle, chrome-yellow anteriorly; inside of mouth vermilion; iris dark brown, a narrow vermilion ring round the eye, beneath which is a white speck; tarsi and toes brown to blackish. Total

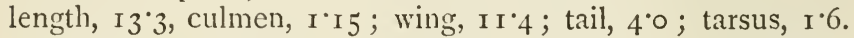

Adult Female.-Similar to the male. Total length, $12 \cdot 5$ inches ; wing, I I $\circ$.

Adult in Winter Plumage.-According to Mr. Saunders, the winter plumage is similar to the breeding dress, excepting as regards the head, which is white, with grey streaks, which coalesce on the nape and hind-neck, producing a greyish-black appearance. The quills become worn and faded in colour, and their tips abruptly broken off, as if cut artificially ; the bill is duller in colour and the tips brown. By the beginning of April the new primaries, with broad white tips, are fully developed, and the head is plentifully besprinkled with slaty-grey.

Young.-Ashy-brown above, mottled all over with ashy-buff edges to the feathers, emphasized by a sub-terminal bar of black; the head rather lighter ashy, with obscure fulvescent margins ; lores and base of forehead, as well as a streak behind the eye, white, as also the fore part of the cheeks; the feathers below the eye and the ear-coverts slaty-grey; under surface of body white, with a large patch of ashy-brown on each side of the upper breast, the feathers being margined with ashy-buff; tail with a conspicuous black band at the end.

Range in Great Britain.-Young specimens of Sabine's Gull have been frequently obtained off our coast, chiefly in autumn and winter, between the months of August and December. Two adults in summer plumage have been recorded, one from Bridlington, in Yorkshire, and another from the Island of Mull.

Range outside the British Islands.-The present species is circumpolar in distribution, and breeds throughout Arctic America from Baffin Bay to Alaska, whence to the eastward it has been found nesting on the Taimyr peninsula, by Dr. Von Middendorff. In winter it visits the shores of Northern Europe as a straggler, but in the New World it goes as far south as the Bermudas and Southern Texas on the Atlantic side, and on the Pacific side the species has been found by 
Commander Macfarlane in swarms as far south as Callao Bay, in Peru. It has not yet been recorded from Novaya Zemlya or Franz-Josef Land, and, according to Mr. Howard Saunders, it is very rare or local in Spitsbergen, while it is believed to be merely a visitor to Jan Mayen.

Habits.-Mr. E. W. Nelson has given an interesting account of this Gull as observed by him in Alaska. He writes :- "My acquaintance with this bird began on my first excursion near Saint Michael's, on June 26, 1877. We were caught by a headtide at the mouth of the 'canal,' some fifteen miles from the fort and tied up to the bank to await the change. We stopped soon after midnight, and taking my gun I strolled off across the marshes in the soft twilight. For some time only the hoarse cries of distant Loons, or the rolling note of a Crane broke the silence. The whole scene was desolate in the extreme; not a living thing could be seen, and the bleaching fragments of drift-wood scattered among the numberless ponds were all that the wide extent of level marsh presented. About r.30 a.m. the sky became brighter, and the rich tones of the Swans, mellowed by the distance to a harmonious cadence, came from the larger lakes, while various other inhabitants of the marsh from time to time added their voices to the chorus. In a few minutes a long straggling train of small Gulls was seen passing over the ponds in silent procession. Approaching them, they were found to be busily engaged in feeding on the small fishes and various small larvæ found in these pools. Their motions and appearance were much like those of Bonaparte's Gull, when seen at distance, but they rarely plunged into the water like the latter, as the Xemas have the habit of hovering gracefully close over the water to pick up a morsel, or of alighting for an instant in the water and rising again on the wing so lightly that scarcely a ripple is made on the surface. Ten or a dozen beautiful specimens were shot without difficulty as the birds flew about. Their food throughout the season consists of sticklebacks at times, but mainly of such small larvæ and crustaceans as occur in brackish ponds. As August draws to a close, young and old forsake the marshes to a great extent, and for the rest of the season are found scattered along the coast, feeding at the water-line on the beaches. 
"On a number of occasions I have mistaken the young of the year of these Gulls for Plover or other Waders as they sought their food along rocky beaches. In such cases they ran out with each retiring wave and back before the incoming one, with all the agility of a Wader.

"Sabine's Gull has a single harsh, grating, but not loud note, very similar to the grating cry of the Arctic Tern, but somewhat harsher and shorter. When wounded and pursued or captured, it utters the same note in a higher and louder key, with such a grating file-like intensity that one feels like stopping one's ears. It has the same peculiar clicking interruptions which are so characteristic of the cry of a small bat held in the hand. A low, chattering modification of this is heard at times as the birds gather about the border of a favourite pool, or float gracefully in company over the surface of some grassy-bordered pond. The same note in a higher key serves as a note of alarm and curiosity as they fly off overhead when disturbed. When one of these Gulls is brought down, the others of its kind hover over it, but show less devotion than is usually exhibited by the Terns."

Nest.-The nests are described by Mr. Nelson as having been found by him on an island near St. Michael's. "The island," he says, "was very low, and the driest spots were but little above the water. Built on the driest places were twenty-seven nests, containing from one to two eggs each, and as many others just ready for occupancy. Four or five nests were frequently placed within two or three feet of each other. In about one half of the cases the eggs were laid upon the few grass blades the spot afforded, with no alteration save a slight depression made by the bird's body. In the majority of the other nests a few grass blades and stems had been arranged circularly about the eggs, and in the remainder only enough material had been added to afford the merest apology for a nest.

Eggs.--Two in number, of a very dark olive-brown with reddish-brown spots, nowhere very distinct, the underlying grey markings being still more obscure. In some examples the spots are congregated near the large end of the egg, but, as a rule, they are generally distributed over the whole surface. Axis, I.6-I.8 inch; diam. $I^{\cdot} 25^{-I} \cdot 35$. 
THE IVEDE-TAILED GULLS. GENUS RHODOSTETHIA. Rhodostethia, Bp. Comp. List B. Eur. and N. Amer. p. 62 ( 1838$)$.

$$
\text { Type R. rosea (Macgill.). }
$$

The present genus, which contains only a single species, has the tail wedge-shaped, the two middle feathers more than half an inch longer than the next pair, and nearly two inches longer than the outermost tail-feather.

I. THE WEDGE-TAILED GULL. RHODOSTETHIA ROSEA.

Larus roseus, Macgill. Mem. Wern. Soc. v. no. xiii. p. 249 ( 1824$)$.

Rhodostethia rossi, Richardson; Macgill. Brit. B. v. p. 618 $\left(185^{2}\right)$.

Rhodostethia rosea, Dresser, B. Eur. viii. p. 343, pl. 594 ( 1877$)$; B. O. U. List Brit. B. p. 192 (1883); Saunders, ed. Yarrell's Brit. B. iii. p. 572 ( 1884 ); id. Man. Brit. B. p. 643 (1889) ; Lilford, Col. Fig. Brit. B. parts xvii. xxiii. (1893) ; Saunders, Cat. B. Brit. Mus. xxv. p. 167 (1896). Larus rossii, Seebohm, Hist. Brit. B. iii. p. 305 (1885).

Adult Male in Breeding Plumage.-General colour above light pearly-grey; quills pearly-grey, with a blackish outer web to the first primary; secondaries white at the ends; rump, upper tail-coverts, and wedge-shaped tail white; head and neck all round white, with a black collar round the latter; under parts white, the under wing-coverts and quill-linings grey; axillaries white; bill black; a vermilion ring round the eye; tarsi, toes, and their webs bright red.

The whole of the white parts in this species are suffused with a beautiful blush of rose-colour, whence the bird is often popularly known as "Ross's Rosy Gull."

Adult in Winter Plumage.-Wants the black collar round the neck, and, according to Mr. Saunders, the rosy colour is not so prominent at this season of the year. 
Young.-Similar to the winter plumage of the adult and wanting the black collar. The head, neck, and under surface of the body white, with a greyish shade on the crown and a little black behind the eye ; tail wedge-shaped and having a black band at the end of all the feathers except the outer ones; feathers of the rump and upper tail-coverts tipped with black ; wing-coverts and innermost secondaries black, with indistinct white tips, forming a band down the wing; bastard-wing and primarycoverts black; primaries black along the outer web and on the inner side of the shaft, the rest of the inner web white, which cuts across the end of the inner primaries and forms a subterminal bar; the innermost primaries white, with a black tip; the secondaries white; tarsi and toes brown.

Range in Great Britain.-One specimen of the Wedge-tail Gull has been recorded from England, having been said to have been shot near Tadcaster, in December, I 846 , or February, I 847 . This example, formerly in Sir IV. Milner's collection, is now in the Leeds Museum. Some doubt has been thrown on the authenticity of the occurrence, as the specimen appears, in the opinion of several naturalists, to have been mounted from a skin and not from a freshly killed bird. As Mr. Saunders points out, however, the species has occurred in Heligoland, and there is nothing improbable in its having turned up in Yorkshire, to which I may add that it would have been difficult for a dealer to have purchased a skin fifty years ago.

Range outside the British Islands.--The following range for this species is given by Mr. Howard Saunders :- "Arctic Regions, N.W. Greenland (Discö); Melville Peninsula; Boothia; Point Barrow, N. Alaska, coming from the direction of Herald Island; St. Michael's, Alaska (once); icy sea from Bering Strait to the mouth of the Lena; Barents Sea between FranzJosef Land and Spitsbergen, including the latter; Faeroe Islands (once); Yorkshire (once); Heligoland (once)." Dr. Nansen discovered the breeding-place of this species on some islands which he has called Hvitenland, in lat. $80^{\circ} 38^{\prime} \mathrm{N}$., long. $63^{\circ} \mathrm{E}$. He writes in the "Daily Chronicle," of November, 3, I896 :-

"This, the most markedly polar of all bird forms, is easily 
recognisable from other species of Gull by its beautiful rosecoloured breast, its wedge-shaped tail, and its airy flight.

"It is, without comparison, the most beautiful of all the animal forms of the frozen regions. Hitherto it has only been seen by chance on the utmost confines of the unknown Polar Sea, and no one knew whence it came or whither it went; but here we had unexpectedly come upon its native haunt, and although it was too late in the year (August, I895), to find its nests, there could be no doubt about its breeding in this region."

Habits.-Little is known of the habits of this rare Gull ; Mr. John Murdoch, of the U.S. Signal Corps, procured a number of specimens at Point Barrow. He writes:- "In I $88 \mathrm{I}$, from September 28 to October 22, there were days when they were exceedingly abundant in small flocks-generally moving towards the north-east-either flying over the sea or making short incursions inshore. Not a single one was seen during the spring migrations or in the summer, but two or three stragglers were noticed early in September - a few out among the loose pack-ice-and on September 21 , I882, they were again abundant, apparently almost all young birds. They appeared in large loose flocks, coming in from the sea and from the south-west, all apparently travelling to the north-east. They continued in plenty for several days-while the east wind blew-all following the same track, moving up the shore, and making short excursions inland at each of the beach lagoons. After September 28th they disappeared till October 6th, when, for several days, there was a large flight. On October 9 th in particular there was a continuous stream of them all day long, moving up the shore a short distance from the beach and occasionally swinging in over the land. None were seen to return. The nature of our duties at the station prevented any investigation as to where they came from or whither they went. They appeared to come in from the sea, in the west or north-west, and travelled along the coast to the north-east. They were not observed on IVrangel Island by either the 'Jeannette,' the 'Corwin,' or the 'Rodgers,' and yet the direction from which they come to Point Barrow in the fall points to a breeding-ground somewhere in that part of the world. May it not be that some land 
yet to be discovered, and north of Wrangel Island, will one day yield a glorious harvest of the eggs of this splendid species? It is difficult to form any idea of what becomes of the thousands which pass Point Barrow to the north-east in the autumn. It is certain that they do not return along the shore as they went. Nevertheless, at that season of the year, they must of necessity soon seek lower latitudes. Perhaps the most plausible supposition is that, soon after leaving Point Barrow, perhaps when they encounter the first ice-pack, they turn and retrace their steps so far out to sea as to be unnoticed from the land, and pass the winter on the edge of the ice-field, proceeding north to their breeding-ground as the pack travels north in the spring."

Nest._As yet undescribed.

Eggs.-The British Museum contains an egg ascribed to this species, from Christianshaab, on the south shore of Discö Bay, in Greenland. The old bird is said to have been shot on the nest, and its skin sent home with the egg, according to Mr. Seebohm, to whose collection it formerly belonged. It is figured in his "Coloured Illustrations of the Eggs of British Birds" (plate 36, fig 6). The egg of the Wedged-tailed Gull seems to be very similar in colour and in character to that of Sabine's Gull, but is a little larger. Axis, $\mathrm{r}^{\circ} 9$ inch; diam. $\mathrm{r} \cdot 3$.

\section{THE TRUE GULLS. GENUS LARUS. \\ Larus, Linn. Syst. Nat. i. p. 224 ( I 766 ). \\ (Type not indicated.)}

In all the remaining Gulls the tail is nearly, or quite square, and in this section of the sub-family Larina, Mr. Saunders places five genera, characterised principally by the size of the hind-toe and its web. Thus the genera Larus and Gaoianus (the latter containing only one species, $G$. pacificus from the southern ocean) have the hind-toe free, and moderately or well-developed.

The genus Leucophaus contains only a single species, L. scoresbyii, from the extreme south of South America, and has the feet coarse and the webs considerably indented, while the hind-toe is joined to the inner toe by a rugose membrane.

In the genus Pagophila, which contains only the Ivory Gull, 
the hind-toe is joined to the inner one by a strong serrated membrane, and in the Kittiwakes of the genus Rissa the hindtoe is obsolete or rudimentary.

\section{THE LITTLE GULL. LARUS MINUTUS.}

Larus minutus, Pallas, Reise Russ. Reichs, iii. p. 702, App. no. 35 ( I 776 ) ; Dresser, B. Eur. viii. p. 373, pls. 599, $599 \mathrm{~A}$ (I87I) ; B. O. U. List Brit. B. p. I9г (I883); Saunders, ed. Yarrell's Brit. B. iii. p. 589 (I884); Seebohm, Hist. Brit. B. iii. p. 3 or (1885) ; Saunders, Man. Brit. B. p. 647 (I889); Lilford, Col. Fig. Brit. B. part xxix. (I894); Saunders, Cat. B. Brit. Mus. xxv. p. I 73 (1896). Gavia minuta, Macgill. Brit. B. v. p. 61 3 (1852).

Adult Male.-General colour above delicate pearly-grey, the wing-coverts like the back, as also the bastard-wing and primary-coverts; quills a little darker pearly-grey, with broad white tips, except on the innermost secondaries, which are like the back; the primaries blackish along the inner web, this black more extended on the first primaries, the outermost being blackish along the outer web also; rump, upper tailcoverts, and tail pure white; head all round black; the nape and hind-neck, as well as the sides of the neck, pure white, extending over the mantle; under surface of body, from the lower throat downwards, pure white, with a tinge of pink; under wing-coverts and axillaries slaty-grey, the median coverts blackish, like the quill-lining; "bill deep lake-red (reddishbrown in preserved skins); tarsi and toes vermilion (drying orange-red); iris brown" (H. Saunders). Total length, 10.5 inches; culmen, 0.85 ; wing, 8.91 ; tail, 3.55 ; tarsus, $1 \cdot 2$.

Adult Female.-Similar to the male. Total length, $\mathrm{IO}^{\circ} 2$ inches; wing, $8 \cdot 3$.

Adult in winter Plumage.-Wants the black head of the summer plumage, the forehead being white, and the vertex, hinder crown, and nape slaty-grey, blackish behind the eye. The grey soon changes to black.

Young.--Blackish-brown above, the feathers with white margins, broader on the scapulars and inner secondaries; lesser 
wing-coverts pearly-grey, but the median and greater coverts blackish, edged with white at the ends; bastard-wing and primary-coverts black; the primaries black along the outer web and down the inner side of the shaft, the rest of the inner web white for its whole extent, except at the tip, which is black, with a white spot at the end of the quill; the inner primaries slaty-grey externally and along the inner edge of the shaft, the tip white with a sub-terminal black bar, the black lessening and the white extending till the secondaries are almost entirely white, excepting for a longitudinal patch of blackish towards the end of the outer web; tail-feathers white, with a black band across the end of all but the outermost; crown of head blackish, the forehead and eyebrows white; the sides of the face white, with some streaks of black behind the eye; entire under surface of body pure white, including the under wing-coverts, axillaries, and quill-lining.

Young in First winter.-Resembles the winter plumage of the adult, but is easily distinguished by the black band at the end of the tail, and the broad black band across the wing, formed by the median and greater coverts. The white lining to the quills also distinguishes a young bird at once.

Range in Great Britain.-The Little Gull sometimes visits us in large numbers, mostly in autumn and winter, but, as might be expected, the greater number of occurrences take place on our eastern and southern coasts, those on the western coasts and in Ireland being much fewer in number.

Range outside the British Islands.-In summer, Mr. Saunders says that the present species inhabits the lakes and marshy districts of sub-Arctic and temperate Europe, extending southwards in winter to the Mediterranean. Through temperate Asia it is found up to the mouth of the Amur River and the Sea of Okhotsk, but has not been noticed in Mongolia or China. It has once been obtained in Northern India, and has been known to wander to the Faeroe Islands, and even to New York State in North America.

Habits.-The small size of the Little Gull distinguishes it at a glance from any of the other British species, and it is much more easily approached than most of the latter. It breeds in 
colonies, and even in winter is more or less gregarious. It feeds on small fishes, but also catches insects on the wing, according to Seebohm, after the manner of a Swallow or a Goatsucker. In winter the same observer states that it feeds principally on marine animals of various kinds, which it picks up on the shore or finds floating on the water.

Nests.-Those found by the late Mr. Meves on Lake Ladoga were built of leaves, sedges, and grass, the lining being finer than the rest of the nest, which was placed on almost floating islets of tangled plants. Both male and female incubate.

Eggs.-Three in number, but sometimes four. Groundcolour olive-brown to clay-brown, spotted with chocolate brown, inclining to blackish, the spots in several examples examined showing a tendency to form confluent blotches near the larger end, the underlying purplish-grey spots not being very prominent. The similarity of some of the eggs to those of the Common Tern is evident, and it is doubtful whether some of the eggs of L. minutus in the Seebohm collection are not really those of Sterna fuviatilis.

The Iittle Gull was found by Russow nesting in Esthonia in company with the Common Tern, an unfortunate circumstance for egg-collectors, as Seebohm says, "for the eggs of the two species are absolutely indistinguishable." Meves distinguished them by the colour of the yolk, which was rich orange-red in the Gull, and ochre-yellow in the Tern. Apropos of this, however, Seebohm states that he was informed by J. E. Palmer that he obtained eggs of the Herring Gull in Ireland, and that those eggs which had a dark ground-colour had deep-coloured yolks, whilst those with a pale ground-colour had pale yolks. Axis, I'5-I.8 inches; diam. I'I 5-I'25.

II. THE GREAT BLACK-HEADED GULL.

LARUS ICHTHYAËTUS.

Larus ichthyaetus, Pall. Reise Russ. Reichs, ii. p. 7 I3 (I 773 ); Dresser, B. Eur. viii. p. 369, pl. 598 (1873); B. O. U. List Brit. B. p. I 90 ( 1883 ) ; Saunders, ed. Yarrell's Brit. B. iii. p. 609 ( 1884 ) ; id. Man. Brit. B. p. 653 (I889); Lilford, Col. Fig. Brit. B. part xxiv. (1893) ; Saunders, Cat. B. Brit. Mus. xxv. p. I 76 (1896). 
Adult Male--General colour above delicate pearly-grey, the wing-coverts like the back; the greater series slightly edged with white at the ends; primary-coverts grey with white shafts and broad white tips; primaries white with a sub-terminal band of black of irregular shape, the first primary black along the outer web; inner primaries and outer secondaries grey with white ends and outer webs; remainder of secondaries pure white, except the innermost, which are grey, broadly tipped with white; lower rump, upper tail-coverts, and tail pure white; head all round black, with a spot of white above and below the eye; hind neck, sides of neck, and entire under surface of body pure white, including the under wing-coverts and axillaries; "bill orange, with a black band at the angle; tarsi and toes greenish-yellow, the webs orange" (H. Saunders). Total length, 29 inches: culmen, $2 \cdot 7$; wing, 19.5 ; tail, $7 \cdot 65$; tarsus, $3 \cdot 35$.

Adult Female.-Similar to the male, but smaller; "iris deep brown; edge of eyelids briçht red, with a conspicuous white patch on each lid; bill wax-yellow, the gape and terminal third dull crimson, with a transverse sub-terminal black band; feet dull Indian yellow, the claws black" (A. O. Hume). Total length, 23 inches; wing, $18 \cdot 2$.

Adult in Winter Plumage.-Lacks the black head of the summer dress, the head being white, mottled more or less with blackish streaks and bases to the feathers. Mr. Saunders says that the black head is often assumed by the middle of February, and the moult of the primaries is then completed.

Young.-Brown above, mottled with grey or darker brown, and with greyish-white edges to the feathers; greater wingcoverts ashy-grey with dark brown centres, and white tips and edges to the inner webs; bastard-wing, primary-coverts and quills black, ashy-whitish along the inner web; secondaries blackish, with white shafts and with white along the edge of the inner webs, and greyish or white along the outer web; lower rump, upper tail-coverts, and tail white, with a broad black band at the end occupying more than the terminal third of the feather; the rump and upper tail-coverts spotted with brown: 
crown of head ashy-whitish, washed and mottled with brown; behind the eye a dusky patch ; sides of face ashy-brown ; under surface of body pure white, with a band of mottled brown spots across the fore-neck and on the sides of the upper breast ; under wing-coverts white, mottled with blackish along the edge of the wings; primaries ashy-blackish below.

Characters.-The large size of this Black-headed Gull renders it easily distinguishable from all the other hooded species, none of which have a wing exceeding fifteen inches.

Range in Great Britain.-This large species has once been obtained in England, an example in full summer plumage having been shot off Exmouth at the end of May or beginning of June, 1859.

Range outside the British Islands.-The Great Black-headed Gull breeds in the districts of the Lower Volga and on the lakes of Central Asia, as far east as Koko-Nor, and it probably inhabits the whole of Thibet in summer. It visits the eastern Mediterranean region in winter, and is found along the Red Sea and in Egypt down to Nubia, while at the same season it visits the shores of the Persian Gulf, and the Indian Ocean as far as Ceylon and Burma.

Habits.-Scarcely anything has been recorded of the habits of the present species. Prjevalsky states that it is a very quarrelsome bird, and that its cry is harsh and like the croak of a raven. Its food consists of fish, crustacea, reptiles, locusts, \&c.

Nest.-Apparently none, the eggs being laid upon the bare sand.

Eggs.-Three in number, and very large. 'The general colour is clay-brown or olive stone-colour, spotted with black or brown, with very distinct spots or blotches of inky-grey. In some eggs the spots are small, so that the egg looks like a gigantic edition of that of the Gull-billed Tern, but in others, particularly those with the olive-tinted ground-colour, there are some very large blotches of black, principally at the larger end. Axis, 2.95-3.3 inches; diam. $2^{\cdot}{ }^{\circ} 5^{-2} 2$. 
11. TIIE MEDITERRANEAN BLACK-HEADED GULL. MELANOCEPHALUS.

Larus melanocephahus, Natterer, Isis, I8I8, p. 8I6; Dresser, B Eur. viii. p. 365 , pl. 597 , fig. 2 (1 878 ) ; B. O. U. List Brit. B. p. I9I (I883); Saunders, ed. Yarrell's Brit. B. iii. p. 604, note (1884); id. Man. Brit. B. p. 65 I (1889); Lilford, Col. Fig. Brit. B. part xxxi. (r895); Saunders, Cat. B. Brit. Mus. xxv. p. I80 (1896).

AduIt Male.-General colour above light pearly-grey, the wingcoverts like the back; bastard-wing pearly-grey, whitish towards the end of the feathers; primary-coverts pearly-grey, as also the primaries, which are white at the ends and along the inner aspect of the inner web; the first primary black from the base of the outer web for about two-thirds of its length ; secondaries white, the innermost pearly-grey like the back; lower rump, upper tail-coverts, and tail pure white; head all round jetblack, with a little patch of white above and below the eye; hind-neck, sides of neck, and under surface of body from the lower throat downwards, pure white, including the under wing-coverts and axillaries; bill rich coral-red, with more or less of a blackish band in front of the angle; tarsi and toes red; a red ring round the eye ; iris dark brown. Total length, I 5.5 inches; culmen, I 45 ; wing, II 4 ; tail, 4.6 ; tarsus, ${ }^{\circ} 95$.

Adult Female-Similar to the male, but a trifle smaller, and with a less robust bill. Total length, 15 inches; wing, II 2.

Adult in winter.-Lacks the black head of the summer plumage, the crown being white, with streaks of ashy towards the nape; a spot in front of the eye blackish; ear-coverts ashy-grey; bill and feet duller in colour.

Young.-Brown above, like other young Gulls. Distinguished from the old birds by the colour of the quills; the primarycoverts and quills blackish on both webs, the first primary with a small longitudinal mark of white near the end of the inner web; the second and third with a good deal more white on the inner web, extending from the base to within an inch and a half of the tip; the white increasing on the inner primaries 
and reaching the outer web, the innermost primaries very pale pearly-grey, with a black spot near the end of the outer web, which is developed into a large black patch on the secondaries; tail white, with a broad black band at the end; head white, with dusky streaks, more distinct on the ear-coverts; bill duller in colour, with more black at the angle; tarsi and toes reddish-brown.

Characters.-The adult of the present species may be easily recognised by its black head, pearl-grey mantle, wing less than I 2 inches, and by its coral-red bill, with a dark sub-terminal zone. (Cf. Saunders, Cat. B. Brit. Mus. xxv. p. I 7o.)

According to the characters given by Mr. Saunders for the distinguishing of the young bird, L. melanocephalus has much more black on the three outer primaries than either $L$. philadelpliia or L. ridibundus, but the amount of white on these quills varies at different stages of the life of these birds, and immature specimens require the greatest care to identify them correctly. In L. melanocephalus the young bird has black on both sides of the shaft of the second and third primary; in L. philadelphic the shaft of the third primary has no black along its inner margin, and very little on the inner web of the first and second. In L. ridibundus the young has no black on the inner line of the shaft in the second and third primaries and scarcely any on the first one, but the three outer primaries have a broad border of black along the margin of the inner web.

Range in Great Britain.-Two examples of this Gull have been obtained in England. One, a young bird, was shot in Barking Creek on the Thames in January, $\mathbf{1 8 6 6}$, and was brought to Mr. Whitely of Woolwich, who mounted it himself, and afterwards parted with the specinien to the British Museum. A second individual was obtained on Breydon Broad, near Yarmouth, in December, 1886 , by Mr. G. Smith. The latter bird, an adult in winter plumage, was seen in the flesh by several competent ornithologists, and both of the specimens have been examined by Mr. Saunders, and identified by him as being Larus melanocephalus.

Range outside the British Islands. - This species, as its name implies, is an inhabitant of the Mediterranean, whence it extends to the Black Sea, and has been said to breed in 
Hungary. It has been known to occur off the mouth of the Somme in Northern France, and there is, therefore, nothing remarkable in the fact that it should occasionally turn up in England.

Habits.-Scarcely any notes have been recorded respecting the habits of this Gull, which has been found in colonies in various parts of the Mediterranean, and apparently nests in many places within this area, though up to the present the eggs found by Mr. Dresser and other ornithologists in Spain have turned out to be those of the Gull-billed Tern, with the flocks of which $L$. melanocephalus often mingles.

Nest.-As yet undescribed.

Eggs.-Three in number, varying very much in colour, the ground tint of some being light clay-brown or buff, while others are very dark chocolate or olive-brown. The spots and blotches are darker brown, and the underlying markings are light purplish-grey. Axis, $I^{\cdot} 9^{-2} \cdot{ }^{\prime} 5$ inches; diam. $I^{*} 4^{-1} \cdot 5$.

\section{BONAPARTE'S GULL. LARUS PHILADELPIIA.}

Sterna philadelphia, Ord. in Guthrie's Geogr. and Amer. ed. ii. p. 3 I9 (I8I5).

Gavia bonapartii (Sw. \& Rich.) Macgill. Brit. B. v. p. 6ro $\left(\mathrm{I} 85^{2}\right)$.

Larus philadelphia, B. O. U. List Brit. B. p. 192 ( 1883 ); Saunders, ed. Yarrell's Brit. B. iii. p. 584 (1884); Seebohm, Hist. Brit. B. iii. p. 307 (1885); Saunders, Man. Brit. B. p. 645 (1889); Lilford, Col. Fig. Brit. B. part xxix. (I894); Saunders, Cat. B. Brit. Mus. xxv. p. I85 (1896).

Adult Male.-General colour above pearly-grey, including the wing-coverts ; all the coverts round the bend of the wing, bastardwing, and primary-coverts pure white ; first four primaries white, with black ends, the first one black along the outer web, the second slightly shaded with grey on the inner web, the third and fourth more distinctly grey on the latter, the rest of the primaries grey, with black near the tips, which show a small terminal grey spot, the black decreasing in extent towards the inner primaries; secondaries grey, with narrow white edges to some of the inner ones; lower rump, upper tail-coverts, and tail white; head all 
round leaden-black, with a spot of white f(athers above and below the eye; hind neck, sides of neck, and under surface of body from the lower throat downwards, pure white, including the under wing-coverts and axillaries, the lower greater coverts tinged with silvery-grey like the quill-lining; bill deep black; tarsi and toes orange-red ; iris datk brown. Total length, I 2.5 inches; culmen, $\mathrm{I}^{\circ} \mathbf{2}$; wing, $10^{\circ} 4$; tail, 3.7 ; tarsus, $\mathrm{I}^{\circ} 4$.

Adult Female.-Similar to the male. Total length, I $2 \cdot 2$ inches; wing, 10॰.

Adult in winter Plumage.-Lacks the black head of the summer plumage, the crown being white, with some streaks of duskygrey towards the nape; behind the eye a spot of greyish-black; tarsi and toes duller in colour.

Young.--Brown above, mottled with grey bases to the feathers; the crown of the head ashy-brown; the forehead and eyebrow white like the hind-neck; sides of face white, with a tinge of buff, which is found on the sides of the neck, finishing on the chest; a spot of black on the ear-coverts; wing-coverts mostly blackish, with grey bases and fulvescent or whitish tips; the secondaries with sub-terminal black markings of large size; primary-coverts white, with broad longitudinal centres of black; the primaries differing in markings from those of the adults, the first one being black along both sides of the shaft, the second having a little black along the middle of the inside of the shaft ; on the third the black on the inside of the shaft is almost absent, but with a good deal of white on the base of the outer web; tail white, with a broad sub-terminal band of black.

Characters.--The chief characters for distinguishing Bonaparte's Gull in the fully adult plumage are its black bill and leaden-black hood. The differences in the young bird from those of the other British species have been detailed under the heading of the foregoing species.

Range in Great Britain.--Some half-dozen examples of this North American species have been obtained within our limits. The first recorded was one killed near Belfast, in Ireland, in 
February, 1848 ; another was shot on Loch Lomond by Sir G. H. Leith Buchanan, in April, $185^{\circ}$; while in England four examples have been chronicled, from Falmouth and Penryn in January, 1865 , one from Penzance in October, 1890 , and one from St. Leonard's in November, 1870.

Range outside the British Islands.-Besides the above-mentioned occurrences of Bonaparte's Gull in Great Britain, the species has been recorded once from Heligoland, but this is the only instance of its capture on the Continent of Europe. It is a strictly North American species, breeding in the Fur countries, and migrating in winter on the east as far as Bermuda and Texas and to California on the west, passing south likewise by the inland lakes and rivers.

Habits.-Sir John Richardson states that this pretty little Gull arrives at its breeding places on Great Bear Lake very early in the season, and before the snow has disappeared. He says: "The voice and mode of flying are like those of a Tern, and like those birds, it rushes fiercely at the head of anyone who intrudes on its haunts, screaming loudly. It has, moreover, the strange practice, considering the form of its feet, of perching on posts and trees, and it may often be seen standing gracefully on the summit of a small spruce fir." Audubon describes how Bonaparte's Gull follows the shoals of fishes, and Mr. E. W. Nelson found the species numerous in flocks on the I $9^{\text {th }}$ and 2 oth of September, along the tide channels near St. Michael's, in Alaska. They were hovering in parties with many Short-billed Gulls, close to the surface of the water, and feeding upon the schools of sticklebacks.

Nest. - Built, according to Sir John Richardson, in a colony, resembling a rookery, seven or eight in a tree, the nests being formed of sticks laid flatly.

Eggs.-Three in number, rarely four. Ground-colour olivebrown, or inclining to dark clay-brown, the spots somewhat reddish-brown, generally distributed over the egg, the underlying spots being dusky-grey. Sometimes the large end of the egg is crowded with scribbling. Axis, $1^{\cdot} 75^{-2} \cdot 1$ inches; diam., I'3-I'4. 
总

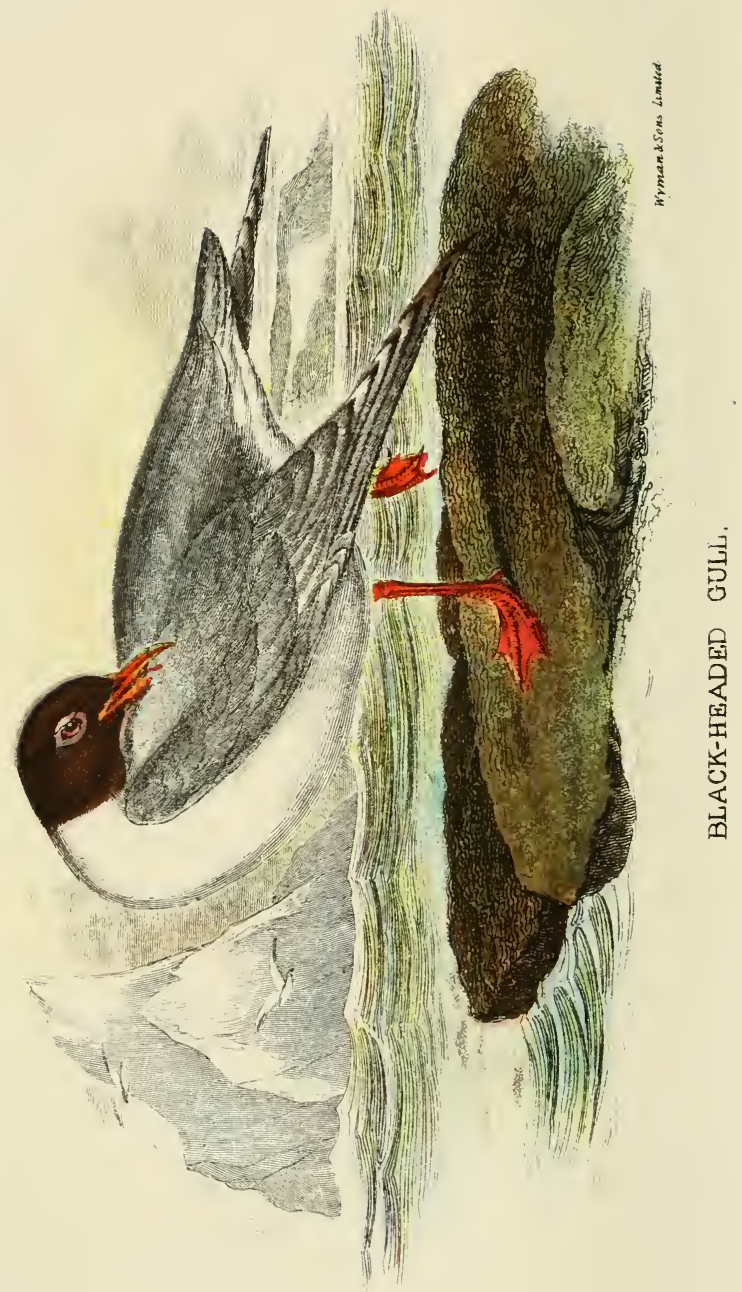


V. THE BLACK-HEADED GULL. LARUS RIDIBUNDUS.

Larus ridibundus, Linn. Syst. Nat. i. p. 225 ( г 766); Dresser, B. Eur. viii. p. 357 , pls. 596 and 597, fig. i. (1878);

B. O. U. List Brit. B. p. I9I ( 1883 ); Saunders, ed. Yarrell's Brit. B. iii. p. 594 (1884); Seebohm. Hist. Brit.

B. iii. p. 310 (1885); Saunders, Man. Brit. B. p. 649 (1889); Lilford, Col. Fig. Brit. B. part xxi. (1892);

Saunders, Cat. B. Brit. Mus. xxv. p. 207 (1896). Gavia ridibunda, Macgill. Brit. B. v. p. 593 (1852). Gavia capistrata, Macgill. t.c. p. 605.

\section{(Plate XCIX.)}

Adult Male.-General colour above delicate pearly-grey, including the wing-coverts; the marginal coverts pure white, as also the bastard-wing and primary-coverts, the latter slightly shaded with pearly-grey on the inner feathers; the three outer primaries white, with white shafts, black tips, and black edging to the inner webs; the first primary black along the outer web, the second and third also, with a narrow line externally; remainder of the primaries grey, with black tips and black margins to the inner webs, the black disappearing gradually on the inner primaries, which have a terminal spot of grey ; the fifth primary white on the outer web, the secondaries entirely grey ; lower rump, upper tail-coverts, and tail white; crown of head as far as the nape, sides of the face, and throat chocolate-brown, darkening towards the edges of the hood, which is very well defined; a ring of white above and behind the eye ; hind-neck from the nape and sides of neck white, slightly overspreading the mantle; entire under surface of body from the lower throat downward white, with a slight rosy tinge, including the axillaries and marginal lower wing-coverts; the lower, median, greater, and primary-coverts grey; "bill, tarsi, and toes lakered; iris hazel" (H. Saunders). Total length, 16.5 inches; culmen, $\mathrm{x}^{\circ} 45$; wing, Ir 9 ; tail, 4.75 ; tarsus, $\mathrm{x}^{\circ} 7$.

Aduit Female.-Slightly smaller than the male, as a rule. Total length, 14.5 inches; wing, II 8.

Adult in winter Plumage.-Differs from the summer plumage in lacking the brown head, the crown being white with a little 
dusky-grey snade on the hinder part; a small dusky spot in front of the eye and another greyish spot behind the ear-coverts. The white under parts have generally a distinct rosy-blush, which is also seen on the white of the primaries.

Young.-Brown above, with sandy-brown edges to most of the feathers, which are grey at the base; the rump and upper tail-coverts white, with sandy-coloured edgings; tail also white, with a band of black at the end of all but the outermost feathers ; lesser wing-coverts white or tinged with grey; median wing-coverts brown, like the inner secondaries, edged with sandy buff; greater coverts pearly-grey; primaries as in the adult, with tiny whity-brown tips, but with much more black on both webs, the black approaching the shaft ; secondaries grey, broadly tipped with white, and with a longitudinal black mark towards the end of the outer web, decreasing in extent on the inner secondaries; head unifo:m brown, the hind-neck white, flecked with brown like the sides of the face; forehead and eyebrows whitish ; feathers in front of the eye, and a large patch on the ear-coverts, dusky-blackish; throat and under surface of body white; fore-neck, chest, and sides of body washed with sandy-brown; "bill dull yellow, passing into black at the angle; tarsi and toes reddish-yellow" (Saunders.)

Regarding the changes of this bird, Mr. Saunders says : "More or less of a brown hood is assumed when the bird is barely a year old, and the band on the tail is lost by the following autumn, when the new primaries appear, with-as has been said-a larger proportion of black than in the adult. In fact, the duration of the immature phase is very short. The bird does not breed until the following (or second) spring. Occasionally the black from the margins of the inner webs of the three outer quills runs in and reaches the shafts, much encroaching upon the usual white centres, though not to the same extent on both wings of the same bird."

Characters.-The dark brown hood of this species easily distinguishes it when adult, and young birds can be told by the broad black edging which compasses the inner web of the first three primary quills.

Range in Great Britain.-This well-known species nests in colonies in various places throughout the three kingdons, and 
is found nesting in large numbers in Scotland, as far north as the Shetland Islands. In Ireland, Mr. Ussher says, it has breeding colonies, large and small, on bogs and on small islands in lakes, sometimes of tens of thousands, as on Killeenmore Bog near 'Tullamere, sometimes of but a few pairs. It is reported to breed in Donegal, Antrim, Down, Armagh, Monaghan, Fermanagh, Cavan, Westmeath, King's County, Queen's County, Tipperary, Kerry, Limerick, Clare, Galway, Roscommon, Mayo, and Leitrim. A few breed on Beginish, a small flat island in the Blasquet group, an unusual instance of a marine breeding-place.

Range outside the British Islands.-The present species is found, according to Mr. Saunders, throughout Europe from the Faeroes, Southern Norway and Sweden, Russia, from Archangel down to the Mediterranean, and across temperate Asia to Kamtchatka, where it also breeds. In winter it visits Senegambia, Nubia, and the Red Sea, the Persian Gulf and the Indian Ocean, China, Japan, and the Philippines.

Habits.-The name "Black-headed Gull" is a decided misnomer for this species, for the hood is brown rather than black, and it is the more inappropriate as there are some Gulls of this group which have absolutely black caps. It is a gregarious species, nesting in colonies, and even in the autumn and winter congregating in flocks, which frequent tidal harbours and are often a conspicuous feature at pier-heads when the tide comes in. I have often seen them circling within a few feet of the heads of the visitors at Gorleston Harbour, on the east coast, and one of the most interesting features of the day was to go and throw food to these pretty creatures at the end of the pier. They are almost equally tame on the Thames when they ascend the river in winter.

Many accounts have been published of visits paid by naturalists to "gulleries" of this species, one of the most renowned being at Scoulton in Norfolk, of which the late Mr. G. Dawson Rowley has given the following account :-

"The first intimation of the proximity of the Gulls was a flight of them feeding in a cornfield near Scoulton Church, 
which, like some others, has a reed-thatched roof-an indication of a fenny neighbourhood.

"The sight of the birds of Scoulton, as they rise in a dense mass, filling the air like snow, is certainly very beautiful ; and the sound of the multitude of voices is music to the ornithological ear.

"'The Gulls chiefly congregate at each end of 'the heath,' as the great island is called, on which Scotch firs and birches grow. If an unfortunate Heron appears, they mob him, and keep even the swans at a respectful distance, with blows on the head. After the Gulls leave, however, the Herons frequently take possession of the mere.

"Mr. Weyland has constructed a path, called the "twentyfoot road,' all round, which makes a dry and agreeable promenade, whence the visitor may view the islets of the broad water, which are named Tea Island, Boat-house Island, \&c., \&c.

"Many years ago the greater portion of Scoulton parish was common land, and the mere is part of the allotment to the Weyland family. Long may it flourish and protect these Gulls, who probably are the oldest inhabitants, as they are mentioned by Sir Thomas Browne as breeding there in his time ; and they may be coeval with the lake itself. The birds arrive some time in February.

"The keeper states that he took 6,000 eggs last season, and these eggs fetch one shilling per dozen. But in the time of the Rev. Richard Lubbock--as mentioned in the "Fauna of Norfolk,' in my edition (1845) -it is said (p. I23) that an average season produces more than 30,000 eggs; five years before that they took 44,000 .

" Mr. J. H. Gurney, jun., writes, in 'Rambles of a Naturalist' (p. 292):-'In 1860, about 16,0co eggs had been gathered. In 1872 , when I went again, only 4,000 were taken. This sad falling off was due to dry seasons. Brown, the keeper, told me that once the farmers spread the fields in the neighbourhood with manure sown with salt, which poisoned the worms, \&c., upon which the Gulls feed, and that a great number died in consequence. IIe said also that they suffered from Stoats and Rats; he had known, on one occasion, 150 of the nestlings and eggs, just chipping, to be destroyed by a Stoat.' "' 
This Gull is often found inland at some distance from water, visiting swamps or even following the plough.

Nest.-Generally placed on the ground, though instances have been known of its being built on a tree, even at seven or eight feet from the ground, or on a boat-house. Seebohm states that he has found nests floating on the water, sometimes slight, at other times quite substantial structures, as big as Coots' nests. "On the Lower Danube," he writes, "the nests were also floating on weeds of various kinds, and were of good size. Although the colony was not a large one, the birds were demonstrative enough, crying loudly, sometimes a single $K a k$, at others $K a k, K a k$, frequently $K a r k$, and occasionally $K a k$, Kark."

Eggs.-Two to three in number, varying greatly in colour, occasionally in the same clutch. Mr. Robert Read writes to me:- "In the vast colonies in which these birds breed, one may find eggs of every size, shape, and colour, from pale spotless greenish-blue to deep brown, heavily marked with black blotches and spots. I have frequently found four, five, and six eggs in a nest, and on one occasion eight, but in most of these cases the produce is undoubtedly that of more than two or more females." The most typical form of egg has the ground-colour dark olive or dark clay-brown, the spots being of all shapes and sizes, often forming confluent blotches of black or brown at the large end of the egg. Many of the overlying spots have a reddish tint, and the underlying markings being dusky-grey. Some varieties are bluish in ground-colour, others nearly white with minute spots, while in a few examples the ground-colour is a deep coffee-brown, on which the markings are scarcely perceptible. Axis, $2 \cdot 0-2 \cdot 3$ inches; diam., $1 \cdot 4-$ I. 55 .

VI. THE GREAT BLACK-BACKED GULL. LARUS MARINUS.

Larus marinus, Linn. Syst. Nat. i. p. 225 ( 1766 ); Macgill. Brit. B. v. p. 526 (1852); Dresser, B. Eur. viii. p. 427, pl. 604 (1872); B. O. U. List Brit. B. p. I89 (1883); Saunders, ed. Yarrell's Brit. B. iii. p. 63 I (1884); Seebohm, Hist. Brit. B. iii. p. 323 (1885); Saunders, Man. Brit. B. 
p. 66 I (1889) : Lilford, Col. Fig. Brit. B. part xxv. (1893); Saunders, Cat. B. Brit. Mus. xxv. p. 24 I (1896).

\section{(Plate C.)}

Adult Male--General colour above black, with a distinct wash of slate-colour, the scapulars tipped with white ; marginal coverts white; wing-coverts like the back; bastard-wing, primary-coverts, and quills slaty-black, the secondaries broadly tipped with white, forming a distinct bar across the wing; first primary with a white tip of nearly three inches in extent; second primary also largely tipped with white, with a subterminal spot of black on the inner web ; third primary almost entirely black, with a white tip ; fourth and fifth primaries with a broad sub-terminal bar of black, preceded by a narrow bar of white on the inner web; rump, upper tail-coverts, and tail pure white; head and neck all round, as well as the upper mantle and the entire under surface of the body, including the under wing-coverts and axillaries, pure white; lower primary-coverts ashy; quill-lining dark slate-colour, with an ashy shade along the edge of the inner web, and a kind of light ashy shade or pale appearance along the inner line of the shaft; "bill yellow, the angle of the genys orange-red; eyelid vermilion; tarsi and toes livid flesh-colour" (H. Saunders). Total length, 28 inches; culmen, 2.6 ; wing, 19.5 ; tail, 7.5 ; tarsus, $3^{\circ} \circ$.

Adult Female.-Rather smaller than the male, and with a less robust bill.

Adult in winter.-Similar to the summer plumage, but with a few greyish streaks on the head, and the colour of the bill not so bright.

Young.--Brown above, thickly mottled with bars of white or sandy buff or light brown, with occasionally a bar of black on the feathers, most of which are broadly edged with sandy or white, with sub-terminal bars or markings of black; rump, upper tailcoverts, and tail mottled with black, the latter marbled with black, in addition to the sub-terminal black bar; primarycoverts and primaries black, tipped with white, the inner webs of the feathers slaty-brown; secondaries brown, blacker on the outer web, edged and tipped with white; innermost secondaries 



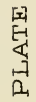
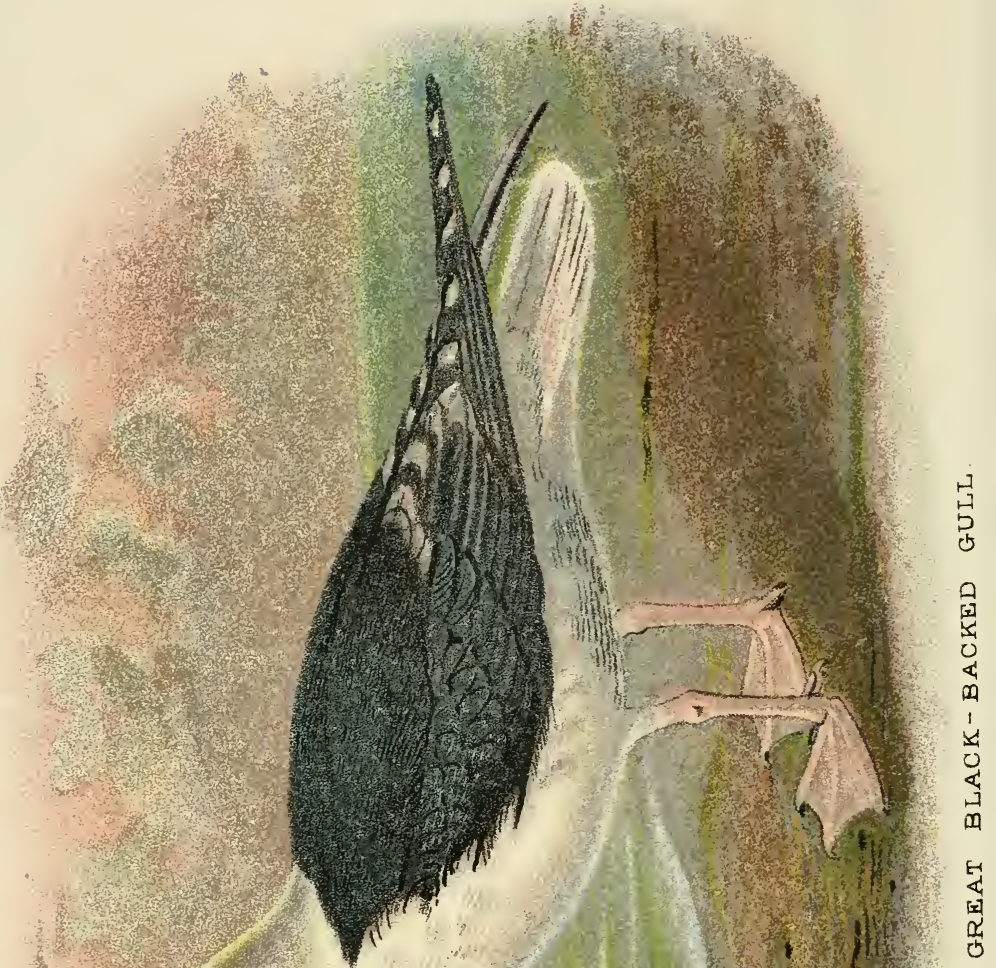

,

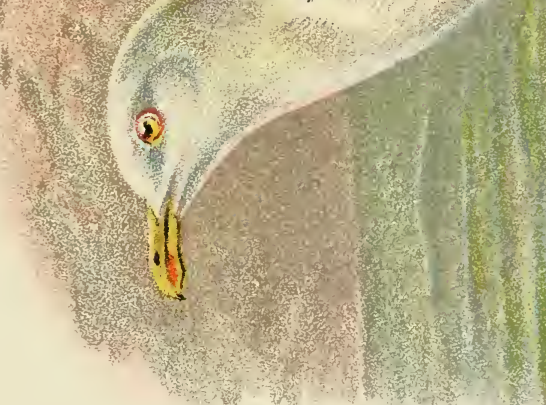


mottled and barred like the back; head and hind-neck white, streaked with brown, more thickly on the hinder crown and nape, and very thinly on the lores, sides of face, and lower throat; chin and upper throat white, unspotted; remainder of under surface of body white, slightly spotted with dusky brown, but more distinctly on the sides of the breast and flanks, where the dusky bars and arrow-head markings are very distinct; under wing-coverts and axillaries white, with dusky bars.

Concerning the changes in plumage of this species when inmature, Mr. Howard Saunders writes :- "Restricting the term 'young' to a bird of two years, at a later stage black feathers appear on the mantle, and the white edges to the secondaries are distinct, but the primaries are still without 'mirrors.' Afterwards the primaries have white tips, and the fourth, fifth, and sixth exhibit what may almost be called subterminal bars, while the outermost quill shows a sub-apical 'mirror' of dull white, and the second quill has an ill-defined brownish-white spot, the tail being still slightly mottled. I do not think that the adult plumage is attained before the bird is in its fifth year, and even then the amount of white on the two or three outer primaries continues to increase with age."

Nestlings.-Ashy-grey above, mottled with blackish-brown spots, blacker and more scattered on the head and hind-neck; under parts white, the breast tinged with orange-buff.

Characters.-The large size (wing over 19 inches), slatyblack back, and white head distinguish this species when adult, as well as the large white tip to the first primary. The size is the best guide for the determination of the young birds, added to the powerful bill, which far exceeds that of the Lesser Blackbacked or Herring Gulls.

Range in Great Britain.-The present species breeds more abundantly in Scotland than in England, where only a few isolated nesting-places are known on the south-western and western coasts. Mr. Ussher says that in Ireland one or more pairs breed on the summits of some stacks and islands off Donegal, Dublin, Wexford, Waterford, Cork, Kerry, Galway, and Mayo, but there is a considerable colony on the Cow Rock, off Dursey Head, Cork, and another colony of at least fifty pairs on the Bills Rocks, off Achill, Mayo. 
Range outside the British Islands.-Northern Europe, from the Lower Petchora westward to Iceland, and down to about $50^{\circ} \mathrm{N}$. (breeding) ; in winter to the Canaries, and along the Mediterranean (rarely) to the Egyptian coast; also on inland waters. Greenland, and also the east coast and the Great Lakes of North America to Labrador (breeding); in winter to Florida, and accidentally in Bermuda ( $H$. Saunders).

Habits.-This is one of the largest and most powerful of all the British Gulls, and is a great robber, for besides its ordinary food of fish, it devours eggs and young birds, and will attack any sickly or wounded bird or even a sheep. It may, indeed, be said to be practically omnivorous, and will even eat carrion. It is less gregarious than the other Gulls, and is seldom seen even in small companies, while in winter it is generally solitary. It is a very wary bird, and I have only managed to capture individuals by baiting a long line at night-time and leaving it on the mud-flats. In this way I caught several at Pagham Harbour years ago, both old and young birds. "The notes," says Seebohm, "are loud and harsh; almost as harsh and almost as unmusical as those of the Raven. Its alarm note might be represented by the syllable Kyaouk, and its call-notes as $a g$ - $a g-a g$. In winter these birds often congregate where fishing is going on."

Nest.-Placed on rocks, or on an islet at some distance from the sea. The nest is a carelessly-made structure, a depression in the ground being lined with grass or sea-weed, with an occasional twig or two.

Eggs.-Two or three in number, of large size. Groundcolour clay-brown, inclining to stone-colour, with scattered spots of dark reddish-brown or black, with underlying grey spots and blotches. The dark overlying spots have not much tendency to coalesce, and are, in some instances, very scattered and of a pale ochre-brown colour. A pair in the Seebohm collection in the British Museum are bluish-white, with hardly a spot on them; they were obtained in South-west Sweden. Axis, $2^{\cdot} 75^{-3} \cdot{ }^{\cdot} 5$ inches ; diam., $2 \cdot 1-2 \cdot 2$.

VII. THE LESSER BLACK-BACKED GULL. LARUS FUSCUS. Larus fuscus, Iinn. Syst. Nat. i. p. 225 ( 1766 ) ; Macgill. Brit. B. v. p. $53^{S}\left(\mathrm{I}_{5}{ }^{2}\right)$; Dresser, B. Eur. viii. p. 42 I, pl. 603 

它

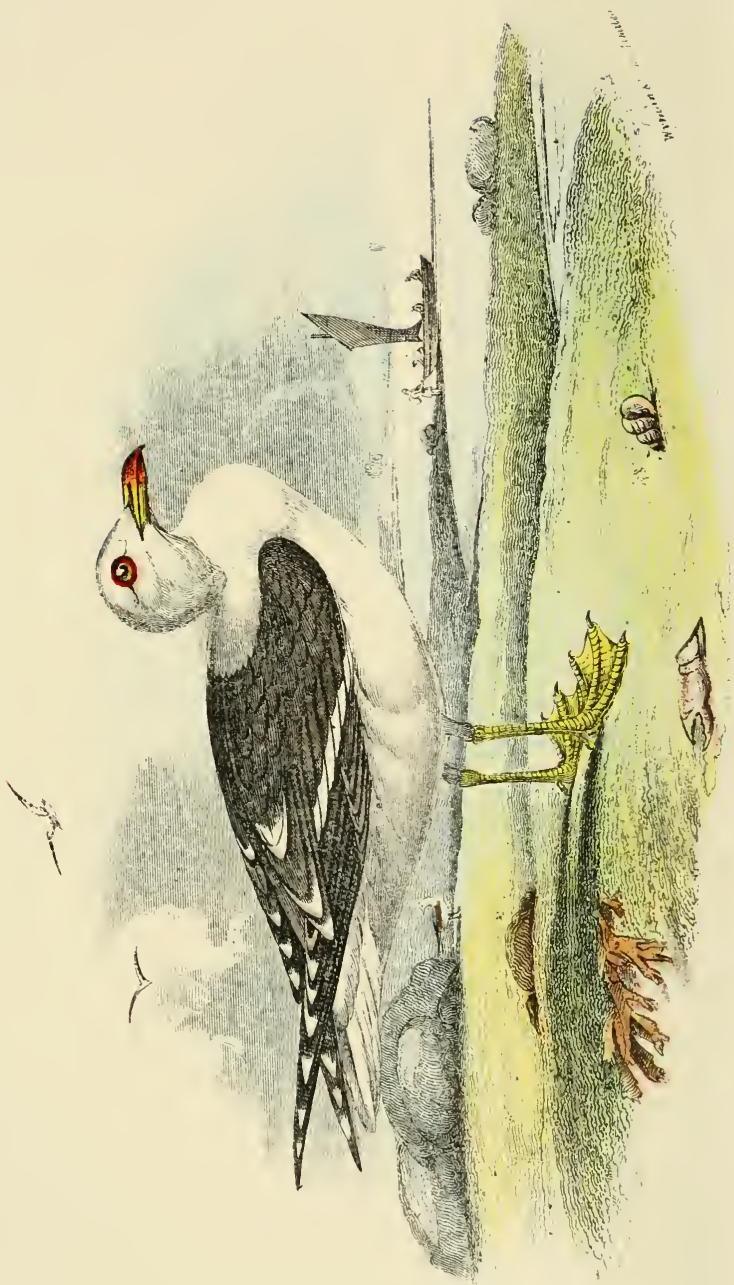

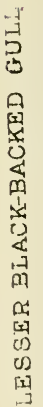


( 1873 ) ; B. O. U. List Brit. B. p. I89 (I883) ; Saunders, ed. Yarrell's Brit. B. iii. p. 624 (I 884); Seebohm, Hist. Brit. B. iii. p. 3 I 9 (I885) ; Saunders, Man. Brit. B. p. 659 (1889) ; Lilford, Col. Fig. Brit. B. part xxiii. (1893); Saunders, Cat. B. Brit. Mus. xxv. p. 250 (I896).

\section{(Plate Cl.)}

Adult Male.-Similar to L. marinus, but very much smaller, and easily distinguished by the outer primaries, which have not the ends white for nearly three inches, but are blackish with a white sub-terminal bar before a black tip. General colour above slate-grey, with the same white ends to the secondaries and scapulars; the head, neck, mantle, and under surface of body white, as also the rump, upper tail-coverts, and tail ; "bill yellow, the angle of the genys red; tarsi and feet lemon-yellow; iris pale straw-yellow" (Saunders). Total length, 19.5 inches; culmen, 2.15 ; wing, 16.4 ; tail, 5.65 ; tarsus, $2 \cdot 6$.

Adult Female.-Similar to the male, but smaller, and with a less robust bill. Total length, $19^{\circ} \circ$ inches; wing, $16^{\circ} 4$.

Adult in winter.-Differs from the summer plumage in having the head and neck streaked with dusky-brown.

Young.-Brown above, with broad white margins, the head brown, streaked with white; sides of face ashy brown, darker on the ear-coverts, narrowly streaked with dusky; throat white; remainder of the under surface of body streaked and mottled with ashy-brown, which is the prevailing colour of the under parts, the sides of the body barred with darker brown; the tail-feathers black for the terminal half, white barred with black on the basal half, the black end decreasing towards the outer feathers. The bill is slaty-grey, the feet flesh-coloured, and the iris brown. It takes four years for the fully adult plumage to be gained.

Nestling.-Greyish-buff, streaked and mottled with black on the upper parts and throat.

Characters.-In examining the series of adult Lesser Blackbacked Gulls in the British Museum, one is struck by the great variation in the colour of the back, from slaty-grey to 
black. On this question Mr. Saunders writes:- "The principal characteristics of $L$. fuscus are the comparatively long tarsus and the small delicate foot. The colours of the mantle and wings are so variable in shade that the palest examples might be mistaken for Larus affinis, but for the large size and coarser foot of the latter. The blackest examples of $L$. fuscus are found indifferently in the Faeroes, Norway, Egypt, and on the Red Sea ; the lightest are, perhaps, from Scotland, and between the extremes there is every gradation." The smaller size distinguishes the present species from the Greater Black-backed or Herring-Gulls, and, when adult, the colour of the legs further serves to separate it from the former species.

Range in Great Britain.-The present species is a resident throughout our islands, but is somewhat local in its breedinghaunts, though, where this Gull nests, it is generally in such numbers that it requires to be kept in check. Mr. Saunders observes:- "In Scotland closely-packed settlements may be found-far too plentifully for game preservers-up to the northernmost Shetlands; especially along the western coast, within the shelter of the outer Hebrides, though on the far side of that group, the Herring-Gull predominates." As regards Ireland, Mr. Ussher's note is as follows :- "Breeds, often in large, numerous colonies, on the sea-cliffs and marine islands of Donegal, Londonderry, Antrim, Dublin, Wexford, Waterford, Cork, Kerry, Clare, Galway, Mayo, and Sligo. It is the species of Gull most abundantly distributed on our coasts in the breeding-season."

Range outside the British Islands.- "Northern Europe, from the Dwina westward to the Faeroes (but not in Iceland), and southward to the Mediterranean (breeding); in winter to the Canaries, Senegal, Fantee, Bonny, Egypt, Nubia, the Red Sea (said to be resident on the last), to Fao on the Persian Gulf. Very rare in the North Caspian, and practically not found east of the line of the Dwina, where the range of Larus affinis begins" (Saunders, Cat. B. Brit. Mus. xxv. p. 253). Occasionally it ranges farther eastward than the above-mentioned limits, as, since the above was written, Mr. Saunders has identified a specimen procured by Mr. H. L. Popham on the Yenesei as L. fuscus (Ibis, I897, p. 106). 
Habits. - Both in the breeding season and during the autumn and winter the present species is gregarious, and, even in the height of summer, small flocks of the Lesser Black-backed Gull may be observed on the flat and open shores of our southeastern coasts-evidently non-breeding birds. It is decidedly the Gull most in evidence on our coasts, excepting the Blackheaded Gull, and is easily procured by any gunner who lies up for it as it flies inland to the ploughed fields or fallow. Like other Gulls, its principal food consist of fish, but it will often be found following the plough, and is frequently to be observed among the shipping on tidal rivers. "It is a wonderful sight," says Seebohm, "on approaching one of the Farne Islands, to see the green mass sprinkled all over with large white-looking birds, every one standing head to wind, like innumerable weathercocks; and it is still more wonderful, when a shot is fired, to see the flutter of white wings as every bird rises in haste, and to hear the angry cries which each bird makes as soon as the exertion of getting fairly launched into the air is over, and it finds breath enough to scream defiance to the invader of its home. In half a minute thousands of birds are flying backwards and forwards in every direction, like a living snow-storm. The various cries of the birds almost exactly resemble those of the Herring-Gull. 'The angry Kyeok (which sounds at a distance when the birds are quarrelling, like $a k$, $a k, a k)$, and the good-natured $h a, h a$, $h a$, or $a n, a n, a n$, are constantly heard."

Nest. $-\Lambda$ slovenly structure of dry grass and dead marine plants and sea-weed.

Eggs.-Three in number, occasionally four. A curious instance of a nest with four eggs is to be seen in the Natural History Museum. This nest was placed in the middle of a sheep-track, and the sheep, in passing to and fro, had to jump over the back of the sitting bird.

Mr. Robert Read writes to me:- "Three is the usual number of eggs in one set, but I have taken four from a nest. In this instance they were very heavily marked and evidently laid by the same bird. The case in the Natural History Museum is another instance of four eggs being found in a nest, although, to judge from the eggs alone, one could not be certain that 
they were all laid by the same bird." Although some of the eggs of $L$. fuscus look like small reproductions of eggs of L. marimus, the general tone of the colour in the Lesser Blackbacked Gull is decidedly darker, and varies from clay-brown or olive-brown to dark chocolate. The black overlying spots run somewhat into blotches, which are often congregated at the larger end of the egg. Axis, $2 \cdot 6-2 \cdot 85$ inches; diam., $1 \cdot 8-I \cdot 95$.

\section{THE HERRING-GULL. LARUS ARGENTATUS.}

Larus argentatus, Gm. Syst. Nat. i. p. 600 ( 788 , ex Brünn.); Macgill. Brit. B. v. p. 544 (I 852 ); Dresser, B. Eur. viii. p. 339 , pl. 602, fig. 2 (1873) ; B. O. U. List Brit. B. p. 188 (I883); Saunders, ed. Yarrell's Brit. B. iii. p. 6r 3 (I884); Seebohm, Hist. Brit. B. iii. p. 3 I 6 (I885); Saunders, Man. Brit. B. p. 655 (г889) ; Lilford, Col. Fig. Brit. B. part xxiii. (I 893); Saunders, Cat. B. Brit. Mus. xxv. p. 260 (I896).

Adult Male.-General colour above delicate pearly-grey ; wingcoverts like the back, the secondaries broadly tipped with white, like the scapulars, forming a conspicuous bar across the wing; bastard-wing pearly-grey, the outer feathers white; primarycoverts and primaries darker grey; first primary blackish, with a grey wedge towards the base of the inner web, the tips white, preceded by a narrow black bar (often absent), which is again preceded by a broad band of white; the second primary with a spot of white at a little distance from the end of the inner web, both these quills grey at the basal portion of the inner web, this grey gradually increasing in extent until the. black becomes but a band near the end of the inner primaries, and finally disappears on the innermost ones; upper tail-coverts and tail pure white, as well as the head and neck all round and the entire under surface of the body. Total length, 22.5 inches; culmen, $2 \cdot 2$; wings, 16.5 ; tail, 6.6 ; tarsus, $2 \cdot 5$.

The white markings on the first two primaries vary considerably. Sometimes the black sub-terminal black band is entirely absent, and the whole tip is white for more than two inches, in other individuals the white spot near the end of the inner web of the second primary is totally absent. 
Adult Female.--Similar to the male, but smaller. Total length,

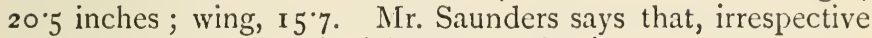
of sex, there is "great individual variation."

Adult in winter.-Similar to the summer plumage, but with brownish-grey streaks on the head and neck.

Young.-On the changes of plumage undergone by the young bird, it is better to quote from Mr. Saunders, as the succession of plumages appears to be somewhat intricate. According to him (Cat. B. xxv. p. 264), in the first autumn, the upper parts are streaked and mottled with brown and greyish-buff ; quills dark umber, with paler inner webs and whitish tips to most; rectrices similar, but more or less mottled with whitish at the bases of the two or three outer pairs ; upper tail-coverts brown, with buffish-white tips; under parts nearly uniform brown at first, but afterwards brownish grey, mottled; bill blackish, paler at the base of the lower mandible.

In the second autumn the head is nearly white, streaked with greyish-brown; the upper parts are barred with brown on a greyish ground, though no pure grey feathers have yet made their appearance on the mantle; quills paler ; tail more mottled with white at the bases of all the feathers.

In the third autumn the feathers of the mantle are chiefly grey, with some brownish streaks down the shafts; a faint sub-apical spot begins to show on the outermost primary ; the tail-coverts are partly white, and the dark portion of the rectrices is much broken up ; under parts nearly white.

In the fourth autumn the sub-apical patch on the first primary is larger, and the quills from the fifth upwards are banded with black and tipped with white; tail-feathers white, slightly vermiculated with brown; bill greenish-yellow basally, reddish-black at the angle.

At the moult of the fifth autumn all brown markings are lost, the primaries have white tips, black bars and grey wedges, though the proportion of dark colouring in the quills is greater than it is in older birds.

Characters.-Though the male Herring-Gull is sometimes nearly as big as a female Great Black-backed Gull, it is easily told by its much less massive bill and by the pearl-grey back. This distinguishes the old birds, and although there is some 
resemblance to each other in the young of the Greater and Lesser Black-backed Gulls and that of the Herring-Gull, the dimensions will generally serve to distinguish the species at all ages.

Range in Great Britain.-The Herring-Gull breeds in all parts of Great Britain where suitable places for its nesting are available. It is almost entirely a coast species and seldom nests on inland waters or lochs. It is the most noticeable of all our indigenous species of Gull, and Mr. R. J. Ussher also says that it is the most widely distributed of any Gull on the coasts of Ireland during the breeding season.

Range outside the British Islands. - The present species breeds in Northern Europe down to the coasts of Northern France, and to the westward of the White Sea. It is also found in North America, breeding as far south as lat. $40^{\circ} \mathrm{N}$. on the Atlantic side, and on the west it is known from the Yukon River to California. In winter it extends to the West Indies and the Mexican coasts, while European individuals visit the Mediterranean in winter, as well the Black and Caspian Seas.

Habits. - The Herring-Gull is principally a shore-feeder, and its name is derived from its supposed habit of following the shoals of small herring-fry, while it is often seen in some numbers round the fishing-boats, where the birds pounce down on any scraps or offal which may be thrown overboard. Like other Gulls this species sometimes comes inland and feeds on worms, grubs, and grain. It is a great robber of eggs, "and when," writes Mr. Saunders, "at some noted and accessible breeding-place of sea-birds, such as Lundy Island, a gun is fired by a tourist-party for the childish pleasure of seeing an immense number of birds on the wing, then is the opportunity of the Herring-Gulls, and every unprotected egg of Guillemot or Gannet is swept from the ledges in an instant!"

Seebohm states that the call-note of this Gull resembles

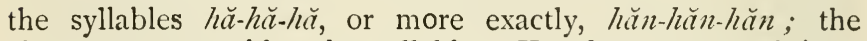
alarm-note resembles the syllables $K y$-eok, pronounced in a guttural manner; and when the bird is unusually excited, its note is rapidly repeated and sounds like $K a \bar{a} k-\breve{a} k-\breve{a} k$ !

Nest.-Mr. Robert Read says that he has generally found the Herring-Gull nesting among larger colonies of the Lesser Black- 
backed Gull on the Farne Islands, Ailsa Craig, Sc., and such appears to have been the experience of Mr. Saunders and other naturalists. The nest is often slight, but is occasionally a bulky structure of grass and seaweeds, with a lining of finer grass and a few straws or stalks of the sea-campion. It is placed on a slope of a cliff or on the grass near the edge of the latter, sometimes in a hollow of the ground in the lowlands or in the crevice of a rock. In America it is known to build in trees or bushes.

Eggs.-Two or three in number, generally the latter, and very similar to those of the Lesser Black-backed and Common Gulls. There is, however, a greater variation in the eggs of the Herring-Gull than in those of the two last-named species, and a very beautiful reddish variety is found near Vardö in the north of Norway, which Seebohm believed to be the egg of the Glaucous Gull. On this point, however, Mr. Henry Pearson and Mr. Edward Bidwell have made some remarks in the "Ibis" for I 894 (p. 236). They procured some of these red eggs themselves in Northern Norway, in a district where there were no Glaucous Gulls. They write :- "The natives ascribe them to the Herring-Gull and say that, however large the colony may be, the red eggs are never found in more than one nest in the colony."

The ground-colour varies in the same way as in the eggs of the Lesser Black-backed Gull, but the Herring-Gull rarely seems to lay eggs of the dark chocolate type. As, however, this is sometimes the case, it may be said that the eggs of the two species are so similar that there is no character by which they can be distinguished, and that too much care cannot be taken in their identification. Axis, 2.6-3.05 inches; diam., I.85-2 I.

\section{THE COMMON GULL. LARUS CANUS.}

Larus canus, Linn. Syst. Nat. i. p. 224 (I 766); Macgill. Brit. B. v. p. 575 (1852) ; Dresser, B. Eur. viii. p. 38 r, pl. 600 (1873) ; B. O. U. List Brit. B. p. I89 (1883); Saunders, ed. Yarrell's Brit. B. iii. p. 6 I 3 (1884); Seebohm, Hist. Brit. B. iii. p. 3 I 6 ( $138_{5}$ ); Saunders, Man. Brit. B. p. 655 (1889); Jilford, Col. Fig. Brit. B. part xx. (IS91); Saunders, Cat. 13. Brit. Mus. xxv. 1). 277 (1896). 
Adult Male.-General colour above delicate pearl-grey; the wing-coverts like the back; the secondaries and scapulars plainly tipped with white, forming a bar across the wing; bastard-wing and primary-coverts pearly-grey, the outer ones white; primaries blackish, with a small white tip and a broad sub-terminal bar of white on the two outermost; the first primary with a grey base to the inner web, much more extended at the base of both webs in the second primary, and gradually extending on the other quills till they are almost entirely grey, with a black sub-terminal bar before the black tip; the inner primaries and all the secondaries grey with a white tip; rump, upper tail-coverts, and tail pure white; head and neck all round, as well as the under surface of the body, pure white, including the under wing-coverts and axillaries; quill-lining dusky-grey, lighter grey towards the base, and with the same pattern of white sub-terminal bars as the upper surface; "bill greenish-yellow at the base, rich yellow terminally; tarsi and toes greenish-yellow; iris golden-brown; orbital ring vermilion" (Saunders). Total length, I 8 inches; culmen, I'5 ; wing, 13.6 ; tail, $5^{\circ} 4$; tarsus, $2{ }^{\circ}$.

Adult Female.-Similar to the male, but smaller. Total length, I $7^{\circ} \circ$ inches ; wing, $\mathbf{2} \mathbf{2}^{\circ}$.

Adult in Winter Plumage.-Similar to the summer plumage, but with the head and neck streaked with ashy-brown, and with the tarsi and toes olivaceous.

Young.-Brown above, with white or buff bars and margins to the feathers; under surface of body white, mottled with brown or ashy-brown. The young bird thus resembles the immature Herring-Gull, and is of the same pale colour. It is, however, easily recognisable from the young of the latter species, as well as from that of the Lesser Black-backed Gull, by its smaller size. The young birds go through similar changes of plumage to those of the allied species of Gull, and Mr. Saunders says that the bird only gains its fully adult livery, and breeds, when nearly three years old.

Characters. - In its light pearly-grey mantle and back, the Common Gull resembles the Herring-Gull, but can always be told by its smaller size, the wing never exceeding 16 inches in 
length. By this means also the young birds of the two species can be distinguished.

Range in Great Britain.-This species breeds in Scotland, but Mr. Saunders states that he is not aware of any nesting-place in England, or, indeed, south of the Border. In Scotland, however, it breeds not only on the coasts, where such are favourable, but on inland lochs as far north as the Hebrides, the Orkneys, and Shetland Isles. In Ireland, Mr. Ussher says, it breeds in small colonies, and in separate pairs, on islands in lakes (usually near the coast) of Donegal, Mayo, and Galway, but sometimes at a distance from the sea, as in Lough Mask and Lake Dahybawn in Mayo, an island on the latter containing a colony of some fifty nests. There are some marine breeding-places, as on islands in Blacksod Bay, and a few pairs breed on one of the Blasquet Islands, off Kerry.

Range outside the British Islands.-According to Mr. Saunders, the Common Gull is found in Europe and Northern Asia down to about $53^{\circ} \mathrm{N}$. Lat., where it breeds. In winter it is found in the Mediterranean Basin, the Nile Valley, and the Persian Gulf. It also extends from Kamschatka to Japan and China. It is a rare bird in Iceland, and only one instance of its capture in North America has been authenticated, a young bird having once been obtained in Labrador.

Habits.-These resemble those of the other British Gulls described above. It is more or less gregarious, but in the autumn many single birds are to be observed on our coasts and estuaries. Its food consists of fish, but it will also come inland and follow the plough for the sake of worms and grubs, while, like other Gulls, it will also eat young birds. In some parts of its range it adopts the deserted nest of a Hooded Crow, or other bird, in a high tree, on the summit or the branches of which it will be seen to perch.

Nest.-A rough structure of grass or seaweed in the open, but sometimes it will be placed on the ledge of a cliff, or on the top of a rock, or even, as remarked above, on a tree. Mr. Robert Read writes to me :- "I have always found the nests of the Common Gull on the shores of fresh-water lakes, or on the islands in one of these waters. The birds are particularly fond of nesting on isolated rocks, sometimes on a boulder, 
only a foot of which is projecting above water. In Sweden, on a group of large rocky islets in a fresh-water lake, I never found more than one nest on each islet."

Eggs.-Three in number. Ground-tint of a clay- or olivebrown to chocolate, with reddish-brown or black spots and streaks distributed fairly over the whole egg, and seldom forming blotches. Sometimes the dark spots show up faintly, and the grey underlying ones are almost as distinctly indicated. Axis, $2^{\cdot} \cdot 5^{-2} \cdot 45$ inches; diam., $\mathbf{I}^{\cdot} 6-1 \cdot 7$.

\section{THE GLAUCOUS GULL. LARUS HYPERBOREUS.}

Larus hyperboreus, Gunnerus, in Leem's Beskr. Finn. Lapp. p. $283(1767)$.

Larus glaucus, Fabr.; Macgill. Brit. B. v. p. 557 (1852); Dresser, B. Eur. viii. p. 433, pl. 605 (I877); B. O. U. List Brit. B. p. I8 7 ( $\left.188_{3}\right)$; Saunders, ed. Yarrell's Brit. B. iii. p. 636 (1884) ; Seebohm, Hist. Brit. B. iii. p. 330 (1885); Saunders, Man. Brit. B. p. $66_{3}$ (r889); Lilford, Col. Fig. Brit. B. parts xxiii. xxvii. (IS93-94); Saunders, Cat. B. Brit. Mus. xxv. p. $289(1896)$.

(Plate CII.)

Adult Male.-General colour above very pale pearly-grey, the wing-coverts like the back; the marginal-coverts round the bend of the wing white; bastard-wing and primary-coverts grey; primaries pearly-grey, with white shafts, gradually becoming white at the ends; the secondaries and scapulars broadly tipped with white; the rump, upper tail-coverts, and tail white; head and neck all round, as well as the whole of the under surface of the body, pure white; "bill yellow, orange-red at the angle; tarsi and toes light fleshy pink in life ; iris, yellow; orbital ring, orange" (H. Saunders.) Total length, 25 inches ; culmen, 2.75 ; wing, 18.0 ; tail, 6.7 ; tarsus, $2 \cdot 8$.

Adult Female.-Smaller, often considerably so, according to Mr. Saunders, who says there is also considerable difference in the size of individuals, irrespective of sex.

Adult in winter. - Similar to the summer plumage, but having the head and neck streaked with pale ashy-brown.

Young. - Very pale ashy-brown both above and below, the bases of the feathers whiter, the back and wings mottled with 

言

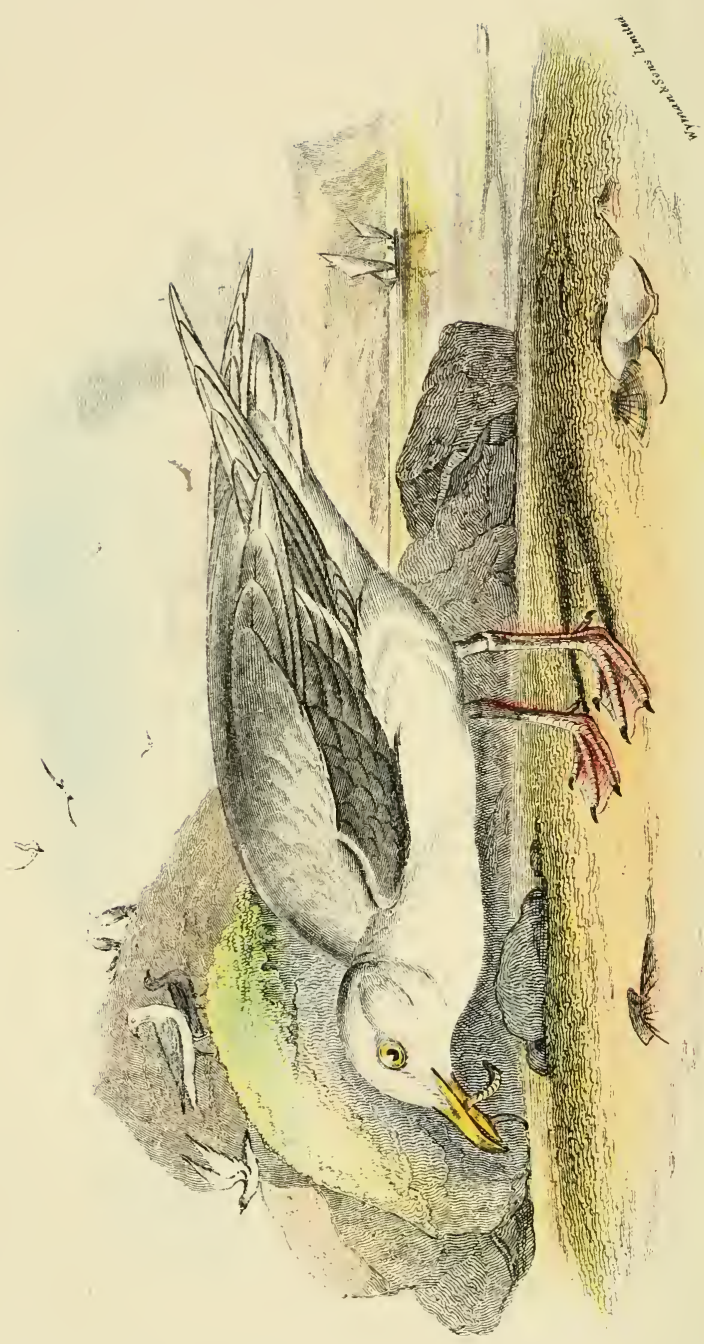

3
0
0
0
0
0
0
0
4
0 
broken bars of pale brown; the secondaries white at the ends and mottled with brown like the back; the primaries isabelline, ashy-white on the inner webs, and with slight remains of brown markings at the ends; upper and under tail-coverts white, distinctly mottled with brown; the tail-feathers ashy-brown, mottled on the edges with white; crown of head ashy-brown, slightly darker than the mantle, and streaked like the side of the face; under surface of the body ashy-brown, the throat whiter, streaked with ashy; under tail-coverts white, barred with light ashy-brown; the under wing-coverts and axillaries ashy-brown like the breast; bill ochre-yellow to the angle, then blackish to the tip; tarsi and toes brownish.

Mr. Saunders says that, after the moult of the next year, both the upper and under surfaces are much lighter, and pale grey feathers begin to show on the mantle, the outer primaries being ali but white. In immature birds the mottlings of the upper surface gradually disappear, and for a short time the bird appears to be creamy white (in which phase of plumage it has received the name of $L$. Intchinsi). At the subsequent moult the pearl-grey mantle is assumed, but the new tail-feathers show some faint brownish mottlings until the next year.

Nestling.-Of a stone-grey colour, slightly tinged with yellowish-buff below; the back mottled with ashy-brown, and the head spotted with black.

Characters. - The Glaucous Gull is distinguished by its large size, white head and tail, and especially by its white quills, with a faint shade of grey at the base. Only two Gulls of the white-winged group answer to this latter character, the Glaucous Gull and the Iceland Gull.

Range in Great Britain.-This is an Arctic species, which visits us in winter only, and is then chiefly noticed in the northern parts of the British Islands. It is a more or less regular visitor, sometimes occurring in numbers, but less often on the west and south coasts; young birds predominating.

Range outside the British Islands. - A circumpolar species during the breeding season, wandering southwards in winter to the Mediterranean, Black and Caspian Seas; also recorded from Japan. In America it visits the Great Lakes, and reaches to Bermuda and Florida, and on the west coast of California 
Habits.-The "Burgomaster," as this great Gull is often called, is a rapacious and omnivorous species, robbing other Gulls of their prey, and feeding on fish, offal, crustacea, and young birds. Seebohn thus describes his experiences of the species in the north of Norway :- "The Glaucous Gull breeds on the cliffs at Vardö, and a large flock, composed principally of immature and entirely of non-breeding birds, frequents the stretches of sand left at low water near Vadsö, thirty niles to the south of the breeding colony. When I was at this town, the Glaucous Gulls were always to be seen at all hours flying about the harbour; but by far the greater portion of them retired to a distant sand-bank, which extended from the southern promontory of the island in the Varanger Fjord, apparently to roost, as the sun approached the north. They were very noisy before finally settling down to rest, continually uttering their loud and harsh note, which may be represented by the syllables 'cut-luk.' Although at Vardö the Glaucous Gull breeds on the precipitous cliffs, Harvie-Brown and I afterwards found its nest on one of the low flat islands which separate the lagoon of the Petchora from the Arctic Ocean. This island was a flat desert of sand, unrelieved by a blade of grass, and it rises very slightly above the level of the sea, which varies very little (only five or six inches) with the tide."

Nest.-The nests found by Seebohm on the Petchora are described by him as "heaps of sand hollowed slightly at the apex, and lined with some irregularly disposed tufts of seaweed." Mr. Trevor-Battye thus describes the breeding of the species on the island of Kolguev:- "The nests of the Glaucous Gulls which we visited were situated on the highest ridge of the outer sand-banks to the south of Scharok Harbour. They were visible from a very long distance, and proved to be lumps formed of sand and mixed with sea-weeds and great quantities of hydrozoa (Sertularia and others), on which flourished Arenaria peploides. The sand had in many cases originally collected round drifted timber, and the birds had taken advantage of this to raise upon it a pile some two feet and more in height. As the Samoyeds rob these nests constantly, one wonders that any young get off. Hyland was so violently mobbed by these birds, which stooped right down at his head, that he shot two "in self-defence." " 
Eggs. - Three in number. There is nothing very distinctive about the colour or markings of the eggs, which look like larger editions of those of the Lesser Black-backed Gull. Some examples are very sparsely marked, and have the spots few and far between, or else have a large blotch of black near the large end of the egg. Axis, 2:95-3.05 inches; diam., $2 \cdot 0-2 \cdot$ I 5 . To the red variety of the Herring-Gull's egg, figured by Seebohm as the egg of the Glaucous Gull, I have already alluded (supra, p. 73).

XI. THE ICELAND GULL. LARUS LEUCOPTERUS.

Larus leucopterus, Faber, Prodr. Isl. Orn. p. 9 I (1822); Macgill. Brit. B. v. p. $566\left({ }_{1} \delta_{52}\right)$; Dresser, B. Eur. viii. p. 439, pl. 606 (1876); B. O. U. List brit. B. p. г 88 (1883); Saunders, ed. Yarrell's Brit. B. iii. p. 642 (1884); Seebohm, Hist. Brit. B. iii. p. 333 (1885) ; Saunders, Man. Brit. B. p. 665 (1 889) ; Lilford, Col. Fig. Brit. B. part xxvi. (1 893); Saunders, Cat. B. Brit. Mus. xxv. p. 295 (1896).

Adult Male.-Similar to L. hyperboreus, but smaller, with proportionately longer wings ; back delicate pearly-grey, with white ends to the secondaries and scapulars; primaries pearly-grey, white at the ends and along the inner webs; rump, upper tailcoverts, and tail white; head and neck all round, as well as the entire under parts, pure white. Total length, 23.5 inches; culmen, I.9 ; wing, I 6.5 ; tail, 6.6 ; tarsus, $2{ }^{\circ} 4$.

Adult Female.-Similar to the male, but smaller.

Young.-Like that of $L$. hyperboreus, and having the under surface light ashy-brown, with very pale brown mottlings on the upper surface. The size is, however, smaller.

Characters. - Like L. hyperboreus, the present species has white quills, but is distinguished from the latter bird by its smaller size. Mr. Saunders observes (Cat. B. Brit. Mus. xxv. p. 297): - "On the wing $L$. leucopterus has a much more buoyant flight than L. glaucus, and the length of wing, in proportion to its comparatively small bulk, is very noticeable; but prepared and over-stuffed skins sometimes offer difficulties. Still, in spite of its longer wing in proportion to its bulk, the largest male $L$. leucopterus does not attain to the length of wing found in the smallest L. glaucus." 
Range in Great Britain.--This small representative of the Glaucous Gull is only a visitor to Great Britain, though it sometimes appears in some numbers off the coasts of Scotland; it is of rarer occurrence off the English and Irish coasts.

Range outside the British Islands.-The breeding-range of the Iceland Gull is in the Arctic regions, in Greenland, Jan Mayen Island, and, according to Saunders, perhaps on the American side of Baffin Bay. In winter it visits Iceland and ${ }_{\S}$ the Faeroes, as well as the shores of Scandinavia and the Baltic, and the north-west of Europe down to the Gulf of Gascony in severe seasons. In North America it descends to the latitude of Boston.

Habits.-The only account of the habits of the Iceland Gull is that of Faber, of which an epitome is given in Saunders's edition of Yarrell's "British Birds" (iii. p. 646). About the middle of September both old and young birds appear off the coast of Ireland for the winter, disappearing about the end of April or the beginning of May. "These birds," says Faber, "were so tame that they came on land up to my winter dwelling on the northern coast to mop up the entrails of fish thrown away by the inhabitants, and disputed fiercely for them.with the Ravens. I had one of these Gulls so tame that it came every morning to my door at a certain time to obtain food and then flew away again. It gave me notice of its arrival by uttering its cry. This Gull indicated to the seal-shooters in the fjord where they should look for the seals by continually following their track in the sea, by hovering in flocks, and with incessant cries, over them; and whilst the seals hunted the sprat and the capeling towards the surface of the water, these Gulls precipitated themselves down upon the fish and snapped them up. In like manner they follow the track of the cod-fish in the sea, and feed upon the booty hunted up by this fish of prey. . . . This Gull was my weather-guide in winter. If it swam near the shore, and there, as if anxious, moved along with its feathers puffed out, then I knew that on the following day storms and snow were to be expected. In fine weather it soared high in the air. Hundreds often sit on a piece of ice, and in that way are drifted many miles. In its manners the Iceland Gull differs from the Glaucous Gull, which has the 
habits of the Greater Black-backed Gull, and moves with more energy. The nature of the Iceland Gull resembles more that of the Herring-(iull ; its deportment and flight are more graceful ; it hovers over its prey, is somewhat greedy, always active, and is not afraid to fight with equal, or superior, antagonists for its food."

Nest.-Has apparently not been described beyond the fact that it is a depression in the bare ground or on the ledges of precipices (Cf. Saunders, l.c.).

Eggs.-Two or three in number, laid early in June. The British Museum contains several specimens from the Seebohm and Gould collections. They are very similar to the eggss of L. hyperboreus, but are rather smaller, and have the groundcolour dark clay-brown, spotted all over with chocolate-brown, and with very evident underlying spots of purplish-grey. Some have the ground-colour greyish-olive, and on this type of egg the spots and blotches are very distinct and plentifully distributed over the surface of the egg. Axis, $2^{\circ} 7-2^{\circ} 9$ inches; diam., $\cdot 85-\mathbf{I} \cdot 2$.

TIE IVORY GULLS. GENUS PAGOPIILA.

Pagophila, Kaup, Natürl. Syst. pp. 69, I96 (1829).

Type P. eburilea (Phipps).

The beautiful Ivory Gull is the sole representative of the genus Pagoplila, which is thoroughly Arctic in its habitat. Its uniform snowy plumage finds a curious parallel in the Antarctic Snowy Petrel (Pagudroma nivea) of the Southern Ocean. The genus Pagophila is characterised by the square tail, the hindtoe joined to the inner one by a strong, scrrated membrane, all the nails being large and curved, the webs and toes being rugose, while the tibia is feathered nearly to the tibio-tarsal joint. (Saunders, Cat. B. Brit. Mus. xxv. p. I6I.)

The genus is represented by a single species, Pagophila eburnea, which is circumpolar in its distribution.

\section{THE IVORY GULL. PAGOPHILA EBURNEA.}

Larus eburneus, Phipps, Voy. N. Pole, App. p. I87 (1774); Seebohm, Hist. Brit. B. iii. p. 337 (1885).

Cetosparactes eburneus, Macgill. Brit. B. v. p. 508 (1852). 
Pasophila elurnea, Dresser, B. Eur. viii. p. 349, pl. 595 (1877); B. O. U. List Brit. B. p. $186(1883)$; Saunders, ed. Yarrell's Brit. B. iii. p. 656 (г 884 ); id. Man. Brit. B. p. 669 (г889) ; Lilford, Col. Fig. Brit. B. part xxvi. (1893) ; Saunders, Cat. B. Brit. Mus. xxv. p. 30 I (I896).

Adult Male.-Entirely snow-white above and below ; the quills also white, with white shafts and a faint shade of grey on the inner web; "bill, gamboge-yellow terminally, merging into greenish-grey on the basal two-thirds of both mandibles; tarsi and toes black; iris dark hair-brown; orbital ring brick-red" (H. Saunders). Total length, 18 inches ; culmen, 177 ; wing, I. 4.2 ; tail, 6.2 ; tarsus, $1 \cdot 75$.

Adult Female.-Similar to the male, but slightly smaller, and Mr. Saunders states that there is a tendency to show a shorter tarsus. Total length, 17 inches; wing, $12 \cdot 8$.

Young.-White, but with a great deal of grey on the lores, sides of face, and throat. The upper surface and the wings spotted with greyish-black; the bastard-wing, primary-coverts, and primaries with a black spot at the end; tail-feathers with a black sub-terminal band.

Nestling.-White. "Even in this stage," says Professor Collett, "they may be distinguished from the young of other species by the strong and hooked claws, particularly on the hind toe, the somewhat marginated web on the toes, and by the forward nostrils." The fledgeling is said by Mr. Saunders to be of a dull or smoke-grey colour.

Range in Great Britain.--Some thirty occurrences of the Ivory Gull have been recorded from British waters, of which half have been adult individuals. They have been procured in England, Ireland, and Scotland, though the greater number, as might have been expected in a winter visitor from the north, have occurred in the latter kingdom.

Range outside the British Islands. - "Circumpolar regions, without any break of continuity; but along those portions of the coast of Arctic America, where open water is non-existent, the bird is naturally scarce; rare also in the Northern Pacific. In winter, southwards as far as the coast of France and Lake Leman (once), and New Brunswick, in America" (Saunders) 
Habits. - The flight of the Ivory Gull is described by Colonel Feilden as being more like that of a Tern than of a Gull, and he says that it has a shrill note, not unlike that of the Arctic Tern. Its food consists of marine animals, as well as the droppings of walruses and seals, and the refuse of the carcases of the latter animals and whales cast aside by the hunters. Numbers were observed by Malmgren sitting for hours round the ice-holes through which the seals came up, looking as if they were sitting round a council-table; "a practice which has doubtless given rise to the curious name used by Martens in I675 for this Gull, viz., 'Rathsherr' (Councillor), a name analogous in its derivation to that of 'Bürgermeister' (Mayor), used for the Glaucous Gull" (Saunders).

Nest.-Composed of green moss, according to Professor Collett, this moss forming one-tenth of its mass. "The nest consists of small splinters of drift-wood, a few feathers, single stalks and leaves of algæ, with one or two particles of lichen. No trace of straw is to be found; a couple of pebbles may possibly have appertained to the under layer of the nest. The mosses occur in pieces of the size of a walnut or less, and have evidently been plucked in a fresh state from a dry sub-soil, either on rocks or gravelly places. The feathers, of which a few were found, are snowy-white, and have probably fallen from the brooding bird." The nests are placed, as a rule, on the cliffs, at a height of from fifty to a hundred feet, and are often quite inaccessible. Those described by Professor Collett were obtained on the island of Stor-oën, off Spitsbergen, about sixteen English miles to the east of Cape Smith in $80^{\circ} 9^{\prime} \mathrm{N}$. Lat., by Captain Johannesen.

Eggs.-One, or two, in number. The ground-colour of five specimens sent to Professor Collett, were almost exactly alike, viz., a light greyish-brown tint, with a faint admixture of yellowish-green, such as often appears on the eggs of Larus canus, which, however, have often a deeper brown or greener hue. In structure and gloss all the eggs brought to Professor Collett resemble those of $L$. canus; but the granulations under the microscope are a little coarser, more uneven, and in larger numbers; on the other hand, the granulations are perceptibly finer than in L. fuscus. The eggs are easily dis- 
tinguished from those of the Kittiwake by their greater gloss, the small excrescences are not so crowded together, and are a little more flattened than they usually are in the lastmentioned species. Axis, $2^{\circ} 1_{5-2} \cdot 4$ inches; diam., $\mathrm{I} \cdot 65^{-1} \cdot 75$.

\section{THE KITTIWAKE GULLS. GENUS RISSA.}

Rissa, Stephens, in Shaw's Gen. Zool. xiii. part I, p. I89 (1826). Type, R. tridactyla (Linn.).

The chief character which distinguishes the Kittiwakes from the rest of the Gulls is the rudimentary condition or absence of the hind toe. The tarsus is much shorter than the middle toe with its claw, and the tail shews a slight tendency to be forked.

Mr. Howard Saunders admits two species of Kittiwakes, our own familiar species ( $R$. tridactyla) with dark brown feet and white under wing-coverts, and $R$. brevirostris, from the Arctic Pacific Ocean, with vermilion-coloured feet and grey under wing-coverts. A third form, $R$. pollicaris, with a slightly more developed hind-toe than in normal $R$. tridactyla, and chieflybut not exclusively-from the North Pacific, is recognised by some American naturalists, but is disallowed by Mr. Saunders.

\section{THE KITTIWAKE GULL. RISSA TRIDACTYLA.}

Larus tridactylus, Linn. Syst. Nat. i. p. 224 (1 766); Seebohm, Hist. Brit. B. iii. p. 340 (I 885 ).

Rissa tridactyla (Linn.), Macgill. Brit. B. v. p. 515 ( 1852$)$; Dresser, B. Eur. viii. p. 447, pls. 607, 608 (1878); B. O. U. List Brit. B. p. I 87 ( 1883$)$; Saunders, ed. Yarrell's Brit. B. iii. p. 650 ( $\left(88_{4}\right)$; id. Man. Brit. B. p. 667 (I8S9); Lilford, Col, Fig. Brit. B. part xxiv. (1893); Saunders, Cat. B. Brit. Mus. xxv. p. 305 (1896).

Adult Male.-General colour above light slaty-grey, with narrow white ends to the scapulars; wing-coverts grey like the back ; bastard-wing, primary-coverts, and quills light slaty-grey, the inner primaries fringed at the ends, and the secondaries narrowly tipped with white; the outer primaries grey, white along the inner webs; first primary black along the outer web, and also for two inches at the tips; the second and third primaries also black at the ends, this black tip decreasing on 
the inner primaries, and forming a sub-terminal band on the fourth and fifth, which have white tips, the band on the latter very narrow; on the sixth the sub-terminal bar is very narrow and often reduced to a spot, and is occasionally entirely absent ; rump, upper tail-coverts, and tail pure white; head and neck all round also pure white, extending on to the upper mantle; entire under surface of body pure white; bill yellow, with a greenish tinge : tarsi blackish; toes dark brown. 'Total length, I 6 inches ; culmen, I.7 ; wing, I 2.4 ; tail, 4.75 ; tarsus, $\mathbf{I}^{\circ} 45$.

Adult Female.-Similar to the male. Total length, I $60^{\circ}$ inches; wing, I $3{ }^{\circ}$.

Adult in Winter.-Differs from the summer plumage in having the hinder crown and neck washed with the same grey as the back; in front of the eye a shade of dusky grey, and behind the ear-coverts a patch of blackish, which extends in a feeble degree round the nape, where it nearly forms a collar; bill more olive.

Young.- Similar to the winter plumage of the adult, but with black mottlings across the hind neck, forming a more or less complete black band; the marginal wing-coverts and most of the lesser wing-coverts black, forming a band down the wing, which is continued by the black on the outer webs of the inner secondaries; the primaries with more black on them than in the adults, the inner webs with a long white "wedge," but the black extending along the outer web and for some breadth along the inner edge of the shaft; the fifth and sixth primaries with a sub-terminal bar of black, represented sometimes on the seventh by a black spot; tail with a broad black band at the end, decreasing towards the outermost feathers.

Nestling.-Dark grey, inore fulvescent on the nape; white below; toes brown, the webs yellowish.

Mr. Saunders observes that the birds of Bering Sea and the North Pacific are slightly larger than those of the Atlantic Ocean, and have a "little more development of the usually diminutive hind-toe. Sometimes there is a very minute, but sharply-pointed, nail on each hind-toe, though often on one only. This development is not confined to examples from the North Pacific, for it has been found in birds from the British Islands, Greeniand, and the eastern side of North America." 
Range in Great Britain.-The Kittiwake is a thoroughly indigenous species with us, being found on all our coasts. In summer it resorts to certain headlands and rocky islands to breed, and in some places it does so in enormous numbers. IVell-known colonies of the Kittiwake are those of Lundy Island, the Farnes, Flamborough, the Bass Rock, and they are especially numerous in the Orkneys and Shetland Isles. In Ireland, Mr. Ussher says, the Kittiwake breeds, often in large colonies, on the precipices of the coasts and islands of Donegal, Antrim, Dublin, Wexford, Cork, Kerry, Clare, Galway, Mayo, and Sligo.

Range outside the British Islands. - The present species is found in the Arctic and Sub-Arctic regions, from the farthest point yet visited by man to the north of Spitsbergen and up to $8 \mathbf{I}^{\circ}$ $40^{\prime}$ in Smith Sound, down to the north-west of France, the Gulf of St. Lawrence on the Atlantic side of North America, and the Kuril Islands in the Pacific.

In winter it visits the Mediterranean, and the inland waters of Europe down to the Caspian, the Canaries, Bermuda, and both sides of America to about $35^{\circ} \mathrm{N}$. Lat. The record of circumpolar continuity is complete between the North Cape and Bering Strait, by way of Siberia and the islands to the north, while in Arctic America it is only defective as regards the small interval between Prince Albert Island and Point Barrow (H. Saundirs).

Habits.-Many descriptions of the colonies of Kittiwakes have been published in works on British Ornithology. One of the best accounts of some of the great assemblages of this Gull is that of the late Dr. Alfred Brehm, in his essay on the "Bird-Bergs of Lapland." * He writes :-

"Different again is the life and activity on the bergs chosen as brooding-places by the Kittiwakes. Such a hill is the promontory Swärtholm, high up in the north between the Laxen and the Porsanger fjords, not far from the North Cape. I knew already how these Gulls appear on their breeding-places. Faber, with his excellent knowledge of the birds of the North, has depicted it, as usual, in a few vivid words :

* "From North Pole to Equator : Studies of Wild Life and Scenes in many lands." English Translation, by M, R. Thomson and J. A. Thomson. (Blackie \& Son : I8g6. 
" "They hide the sun when they fly, they cover the skerries when they sit, they drown the thunder of the surf when they cry, they colour the rocks white where they breed.' I believed the excellent Faber after I had seen the Eider-holms and Aukbergs, and yet I doubted, as every naturalist must, and therefore I ardently desired to visit Swärtholm for myself. An amiable Norseman with whom I became friendly, the pilot of the mail steamer by which I travelled, readily agreed to row me over to the breeding place, and we approached the promontory late one evening. At a distance of six or eight nautical miles we were overtaken by flocks of from thirty to a hundred, sometimes even two hundred, Kittiwakes flying to their nesting-place. The nearer we approached to Swärtholm the more rapid was the succession of these swarms, and the larger did they become. At last the promontory became visible, a rocky wall about eight hundred yards long, pierced by innumerable holes, rising almost perpendicularly from the sea to a height of from four hundred and fifty to six hundred feet. It looked grey in the distance, but with a telescope one could discern innumerable points and lines. It looked as though a gigantic slate had been scratched all over with all sorts of marks by a playful giant child, as though the whole rock bore a wondrous decoration of chains, rings, and stars. From the dark depths of large and small cavities there gleamed a brilliant white; the shelving ledges stood out in more conspicuous brightness. The brooding Gulls on their nests formed the white pattern, and we realised the truth of Faber's words, 'they cover the rocks when they sit.'

"Our boat, as it grated on the rocky shore, startled a number of the Gulls, and I saw a picture such as I had seen on many eider-holms and gull-islands. A shot from my friend's gun thundered against the precipice. As a raging winter storm rushes through the air and breaks up the snow-laden clouds till they fall in flakes, so now it snowed living birds. One saw neither hill nor sky, nothing but an indescribable confusion. A thick cloud darkened the whole horizon, justifying the description, 'they hide the sun when they fly.' The north wind blew violently and the icy sca surged wildly against the foot of the cliffs, but more wildly still resounded the shrill cries of the birds, so that the truth of the last part also of Faber's descrip- 
tion was fully proved, "they drown the thunder of the surt when they cry.' At length the cloud sank down upon the sea, the hitherto dim outlines of Swärtholm became distinct again and a new spectacle enchained our gaze. On the precipices there seemed to sit quite as many birds as before, and thousands were still flying up and down. A second shot scared new flocks, a second time it snowed birds down upon the sea, and still the hillsides were covered with hundreds of thousands. But on the sea, as far as the eye could reach, lay Guils like light foam-balls rocking up and down with the waves. How shall I describe the magnificent spectacle? Shall I say that the sea had woven millions and millions of bright pearls into her dark wave-robe? Or shall I compare the Gulls to stars, and the ocean to the dome of heaven? I know not; but I know that I have seen nothing more gorgeous even on the sea. And as if the charm were not already great enough, the midnight sun, erewhile cloucled over, suddenly shed its rosy light over promontory, and sea, and birds, lighting up every wave-crest as if a golden, wide-meshed net had been thrown over the water, and making the rose-tinted dazzling Gulls appear more brilliant than before. We stood speechless at the sight!"

Nest.-Seebohm says that the nest of the Kittiwake is better made than is usual with the Gulls. In some districts the foundation is made of turf, with the soil adhering, which the salt spray and the wet feet of the birds soon turn into a kind of mortar. This foundation is finished off into a nest made of seaweed, pieces of marine vegetation, and finally lined with dry grass and sometimes a few feathers. The nests are generally placed upon ledges on cliffs, but in Alaska they were found on small islands by Mr. Dall, the birds making a simple depression in the sand.

Eggs.-Two or three in number, very rarely four, according to Seebohm, who observes that the eggs of the Kittiwake are not easily compared with those of any other British Gull. Mr. Robert Read writes to me :- "The eggs of the Kittiwake vary as much as those of the Black-headed Gull, and they are found from almost pure white to deep purplish-brown, with still darker markings. They are, however, never so glossy as the eggs of the Gulls, resembling more the eggs of the Puffin in texture." 
The scries in the British Museum varies from the typical Gull's egg of clay-brown with distinct overlying spots of dark brown and underlying spots of grey, to bluish-grey or creamybuff, with the markings faint or very much emphasized. In the faintly-spotted eggs, the grey underlying spots are the most prominent, and in some instances the larger end of the egg is blotched with black. Axis, $2 \cdot 2-2 \cdot 35$ inches; diam., $1^{\cdot} 5-1^{\cdot} 7$.

\section{THE SKUAS. FAMILY STERCORARIIDA.}

In structure the Skuas differ markedly from the Larida, and their habits more resemble those of Frigate-Birds than Gulls, though some of the larger species of the last-named family are robbers by nature. 'These redeem their character, however, by other milder traits, whereas the Skuas are among the most predatory of sea-fowl. They differ from the Gulls and Terns in osteological characters, having only one notch in the posterior margin of the sternum, and the bill is furnished with a very elongated "cere," and is formidably hooked, while the claws are more like those of a bird of prey than those of a sea-bird, being strongly curved and very sharp. Two genera are contained within this Family, both of which are represented in the British Avi-fauna, and are described below.

THE GREAT SKUAS. GENUS MEGALESTRIS.

$$
\begin{gathered}
\text { Megalestris, Bp. Cat. Parzud. p. I I (1856). } \\
\text { Types, M. catarrhactes (Linn.). }
\end{gathered}
$$

The members of the genus Megalestris are four in number, one of them, $M$. catarrhactes, inhabiting the northern ocean, while another, MI. maicormickii, is only known from Victoria Land in the Antarctic Ocean. M. chilensis inhabits the southern coasts of South America, and $M$. antartica is found in the southern ocean from the Falkland Islands eastwards to New Zealand. The principal points of difference between the species of Megalestris and Stercorarius consist in the larger bulk of the former and the shorter tail, the central feathers of which do not project more than half an inch beyond the rest, whereas in Stercorarius this prolongation of the middle tail- 
feathers is a feature of the genus. The tarsus is a little shorter than the middle toe and claw.

\section{THE GREAT SKUA. MEGALESTRIS CATARRHACTES.}

Larus catarrhactes, Linn. Syst. Nat. i. p. 226 ( I 766 ).

Lestris catarrhaites, Macgill. Brit. B. v. p. 479 (1852); Lilford,

Col. Fig. Brit. B. part xxvi. (1893).

Stercorarius catarrhactes, Dresser, B. Eur. viii. p. 457, pl. 609 (1875); B. O. U. List Brit. B. p. 194 (1883); Saunders, ed. Yarrell's Brit. B. iii. p. 664 (1884); Seebohm, Hist. Brit. B. iii. p. 346 (1885) ; Saunders, Man. Brit. B. p. 67 I (1889); id. Cat. B. Brit. Mus. xxv. p. 315 (1896).

Adult Male.-General colour above dark umber-brown, mottled with rufous, the feathers being sub-terminally of this colour, and varied with whitish where the ends of the feathers have worn pale; feathers of the neck rather more pointed, and showing pale straw-coloured shafts; wing-coverts dark umber-brown, slightly mottled with white marks near the ends of the feathers ; bastard-wing, primary-coverts, and quills blackish, the outer primaries with yellowish-white shafts, the first quill white towards the base of the inner web, the next five white at the base of both webs, decreasing in extent on the inner primaries, but forming a conspicuous wing-speculum; tail blackish ; crown of head nearly uniform, dark umber-brown very slightly mottled with reddish-brown centres to the feathers; lores and region of the eye dusky umber-brown, the ear-coverts more rufescent brown; under surface of body pale chestnut rufous, varied with ashy grey bases to the feathers, some of the flank-feathers streaked with white shaft-lines and whitish at the ends; the under tail-coverts deeper rufous, with white shaft-streaks; under wing-coverts and axillaries dark umber-brown, the latter slightly rufous near the ends; "bill black, the cere with a greyish tinge; tarsi and toes black; iris dark brown "(H. Saunders). Total length, $2 \mathrm{I}_{5}{ }^{2}$ inches; culmen, 2.2 ; wing, $16 \cdot 0$; tail, 6.4 ; tarsus, $2 \cdot 8$.

Adult Female. - Similar to the male in plumage, though Mr. Saunders is inclined to believe that she is a little larger than her mate. 
Adult in winter.-Mr. Saunders considers that there is scarcely any difference between the winter and summer plumages, and in the series in the British Museum there is scarcely any perceptible difference in colour, except when the plumage is worn, and then the pointed straw-coloured feathers of the neck become more prominent.

Young Birds.-According to Mr. Saunders, these are very similar to the adults, but have less tendency to acumination and striation of the feathers of the neck, and show somewhat rufous margins to the feathers of the mantle.

Nestling.-Covered with buffish-grey down; more ruddy on the upper surface.

Range in Great Britain.-The Great Skua is an expiring species with us. From its predatory habits, it has been marked out for destruction; but the desire of collectors to possess its eggs has probably done more to contribute to its extermination than any other cause. It is rarely seen on the coasts of England and Scotland during winter, and its breeding-places are now confined to the Shetlands, where two small colonies exist on Unst and Foula, where the birds are protected.

Range outside the British Islands. - The breeding-range of the Great Skua is now restricted to a few localities. It nests in the Faeroes, in Iceland, and has been said to breed in North America, on some islands to the north of Hudson Strait. It occurs occasionally in South Greenland and off the coast of Norway; and wanders in winter as far as the Mediterranean, and, in North America, to the coast of New England.

Habits.-The following note is taken from Mr. Saunders's account of the habits of this species in his edition of Yarrell's "British Birds" (vol. iii. p. 665) :- "There is no difficulty in finding the nests, as the parent birds attack any intruder upon their domain with fierce and repeated swoops. When handling the nestling, I found their assaults were unremitting; first one bird and then the other wheeling short, and coming down at full speed, almost skimming the ground. At about fifteen yards' distance, the strong clawed feet are lowered and held stiffly out, producing for the moment a very ungainly appearance, and it seems as if the bird would strike the observer full in the centre of the body, but on quickly raising the hand or 
stick, the bird rises also, the whirr and vibration of its pinions being distinctly heard and felt. Its ordinary flight is soaring and stately. On leaving the territory of one pair, the attack is taken up by another, and so on, for the Great Skuas do not nest in close proximity. In fearlessness this fine bird is unrivalled; it has been seen to beat off the Sea-Eagle, and no Raven stands a chance against it. For this reason the proprietors of the land protect it ; Colonel Feilden says that in the Faeroes they also do so on account of the estimation in which the young are held for food; but the fishermen shoot the old birds for the sake of the bill (for the neb-toll), feathers, and flesh, the latter making excellent fishing-bait. The stomachs of a pair which were shot were full of the flesh of the Kittiwake, and the castings consisted of the bones and feathers of that small Gull. Heysham has noticed an adult female on the coast of Cumberland, which allowed herself to be seized while she was in the act of killing a Herring Gull. It also feeds on fish offal, and I found by the side of a nestling some disgorged but otherwise uninjured herrings of large size."

The late Dr. Saxby has given the following note on the species in his "Birds of Shetland ":- "The Great Skuas are usually seen singly or in pairs, except during the early summer, when they are assembled at the breeding-grounds; upon these occasions I have seen considerable numbers about the same spot, but even then they were chiefly in pairs, except when they became mixed up by accident. At such times, when the young are about, the birds become very daring, sometimes even knocking a man's hat from his head. A dog has no chance with them, for they buffet him so severely in their rapid swoops that he soon has to retire discomfited. I once had four of them sailing in circles close round my head as I stood upon the crown of the highest hill in Unst, Saxaford, and could almost touch them with my gun, the sound of which, by the way, did not seem to cause them much alarm; perhaps they divined how little they had to fear so far as I was concerned. The female is rather lighter in colour than the male, and is by far the bolder of the two. During the breeding-season the Skua will come to such close quarters with an intruder that I have known a man strike at one with a tether, and entangle it and bring it to the ground." 
In its mode of capturing prey the Great Skua is almost Accipitrine in its habits, and lives chiefly upon the toil of the smaller Gulls, which it follows with fierce pertinacity, and compels them to disgorge the fish they have captured; nor, if one of their number is wounded or in distress, will it hesitate to pursue and seize it. For this reason it is almost as much dreade $d$ as a Peregrine or other bird of prey.

Nest.-A hollow in the moss on the upland moors, with sometimes a bit of grass as a lining.

Eggs.-Two, sometimes only one, laid in May and June. The ground-colour is dark chocolate-brown or olive-brown, so dark that the spots do not stand out in bold contrast, the spots being generally of a reddish-brown colour, sometimes very faint, and at others inclining to blackish, especially when they become confluent at the large end of the egg. Axis, 2.55-2.9 inches ; diam., I $85^{-1} \cdot 95$.

\section{THE SMALL SKUAS. GENUS STERCORARIUS.}

Stercorarius, Briss. Orn. vi. p. I 49 (I 760 ).

Type, probably $S$. crepidatus (Banks).

The genus Stercorarius comprises a few species of much smaller size than the members of the genus Merralestris, though they are equally parasitic in their habits, and are armed with equally fierce talons, and the accipitrine cere of the Great Skuas. The central tail-feathers are elongated beyond the others to the extent of three inches at least, and often to a length of eight or nine inches. The tarsus is distinctly shorter than the middle toe and its claw. (Cf. Saunders, Cat. B. Brit. Mus. xxv. p. 3I4.)

Three species of the smaller Skuas are known, all of them Arctic in their habitat, ranging south in winter, one of them, S. pomatorlinus, wandering at that season of the year into the southern oceans.

I. THE POMATORHINE SKUA. STERCORARIUS POMATORHINUS. Lestris pomarina, Temm. Man. d'Orn. p. 5 I4 (I8I5); Macgill. Brit. B. v. p. $487\left(185^{2}\right)$; Lilford, Col. Fig. Brit. B. part xxi. (1 892$)$. 
Stercorarius pomatorhinus, Dresser, B. Eur. viii. p. 463 , pl. 610 (I877) ; B. O. U. List Brit. B. p. I94 (1883) ; Saunders, ed. Yarrell's Brit. B. iii. p. 668 ( 1884 ) ; id. Man. Brit. B. p. 673 (1889); id. Cat. B. Brit. Mus. xxv. p. 323 (I 896). Stcrcorarius pomarinus, Seebohm, Hist. Brit. B. iii. p. 349 (1885).

Adult Male.-General colour above dark slaty-brown, the lateral upper tail-coverts with some white bars, mostly concealed; wing-covelts like the back; bastard-wing, primarycoverts, and quills blackish-brown, browner on the inner web, and with a good deal of white at the base of the latter, decreasing in extent on the inner primaries; tail blackishbrown; crown of head black, forming a cap, the black extending over the lores, feathers below the eye and fore part of cheeks ; the feathers of the occiput acuminate like those of the hind neck, which is straw-yellow like the sides of the face and sides of the neck; the hind-neck slaty-brown like the back, but mottled with white bars; throat straw-yellow like the sides of the neck, the chin whiter; remainder of under surface of body white, the lower throat and fore-neck mottled thickly with black bars and edgings to the feathers, the sides of the body and flanks also mottled in the same way; the lower abdomen and under tail-coverts nearly uniform slaty-brown, only slightly mottled with white; under wing-coverts and axillaries uniform slaty-brown, the lower primary-coverts lighter slate-grey; bill horn-brown; tarsi and toes reddish-brown. Total length, $2 \mathrm{I}$ inches; culmen, $\mathrm{r}^{\circ} 7$; wing, $\mathrm{I}_{4}{ }^{\circ} 6$; tail, 4.9 ; centre tail-feathers, 7.5 ; tarsus, 2.1 .

Adult Female.-Similar to the male. Total length, 20.5 inches; wing, $14^{\circ} \circ$.

Adult in Winter.-Similar to the summer plumage, but for some years after the attainment of adult-though not mature - plumage, there is a tendency, after the autumnal moult, to show striated feathers on the flanks, as well as on the upper and under tail-coverts. (Saunders, Cat. B. xxv. p. 326.)

The pectoral band is wider in immature birds, the yellow on the neck is not so evident, and the flanks are generally streaked. There are more bars on the under surface of the body, and the upper and under tail-coverts, as well as the under wing coverts, are barred or mottled with black and 
white; the central tail feathers rarely project for more than two inches. Like other members of the genus Stercorarius, the Pomatorhine Skua has a melanistic phase, which is generally considered to occur in old birds only, because of the yellow which is seen on the neck. Mr. Saunders, however, doubts whether any of these dark specimens are really old birds, and he quotes an instance of a specimen kept alive for some years by the late Mr. Booth, which gradually became whiter and whiter on the lower parts of the body.

Young.-Sooty-brown above, the head and neck uniform, but the mantle and back mottled with rufous edgings to the feathers; wing-coverts obscurely edged with rufous, the greater coverts and scapulars somewhat more plainly margined; upper tail-coverts banded with sooty-brown and white or sandybuff; tail-feathers sooty-brown, slightly edged with rufous at the tips; sides of face and throat uniform sooty-brown; under surface of body dull ashy-brown, with concealed whitish bars; the abdomen paler and crossed with dusky bars; the under tailcoverts banded with dusky-brown and buffy-white; sides of body darker than the breast; under wing-coverts and axillaries banded with blackish-brown and white; lower primary-coverts white, with dusky bands at the ends; quills blackish below, with a great deal of white towards the base of the inner web; "bill brown, with a greenish tinge; tarsus often blue or grey in patches; bases of the toes yellowish" (H. Saunders).

Characters. - The larger size and darker feet, with the brown hind-toe distinguish young birds of the Pomatorhine Skua from the young of the other two species of Stercorarius. The adult bird is known by its greater dimensions, the wing being over fourteen inches, and by the greater breadth of the central tailfeathers, which are rounded at the ends, and project four inches beyond the others, being twisted vertically. Saunders, Cat. B. Brit. Mus. xxv. p. 322 ).

Range in Great Britain. $-A$ migrant to the seas of the British Islands, sometimes occurring in large numbers, as in 1879 and I880. Many individuals remain on our southern coasts during some winters, and specimens have been obtained inland after severe gales. On the northward migration in spring, the species is seldom observed. 
Range outside the British Islands. - During the breeding season the Pomatorhine Skua is found in the arctic tundra of both hemispheres, and in winter the species wanders into the southern oceans, having been obtained in Northern Australia, Western and South-western Africa, and on the coast of Peru.

Habits.-Mr. E. W. Nelson, who met with the present species in Alaska, writes: "They are clumsy and cowardly birds as compared with their smaller relatives. When one of this species happen to cross the path of the smaller species, the latter almost invariably gives chase, and beats its clumsy antagonist off the field by repeatedly darting down from above. This attack embarrasses the large bird so much that it flinches and dives, and often alights and watches an opportunity to escape from its nimble assailant. One that was driven to alight in the river thrust its head under water at every swoop of its enemy, and exhibited the most ludicrous terror. When on the wing they usually ward off an attack from one side by a halfclosed wing, and if from above, both wings are raised, forming an arched shield above the back. This large bird has a low, harsh, chattering cry when feeding with its companions. The peculiar twist of the long tail-feathers of this species renders it conspicuous and identifiable at almost any distance."

Mr. H. J. Pearson noticed the Pomatorhine Skua off Novaya Zemlya, but did not succeed in finding a nest. He thinks that many of them do not breed in bad seasons, and adds: "If this idea should prove to be a fact, it may be a provision of nature to prevent the Skuas from becoming too numerous. They are well able to defend their eggs and young from the birds of prey found in the same countries and equally capable of taking care of themselves, so that the only foes they need fear are old age and deficiency of food."

Nest.-A mere depression in the moss.

Eggs. - Two in number. Similar to those of the Great Skua, but much smaller, and not so dark in colour, as a rule. The ground-colour is a very deep olive or clay-brown, the spots being reddish brown, or more often blackish brown, and having a tendency to become confluent round the larger end. Sometimes the overlying markings are vcry faint and the grey 


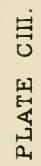

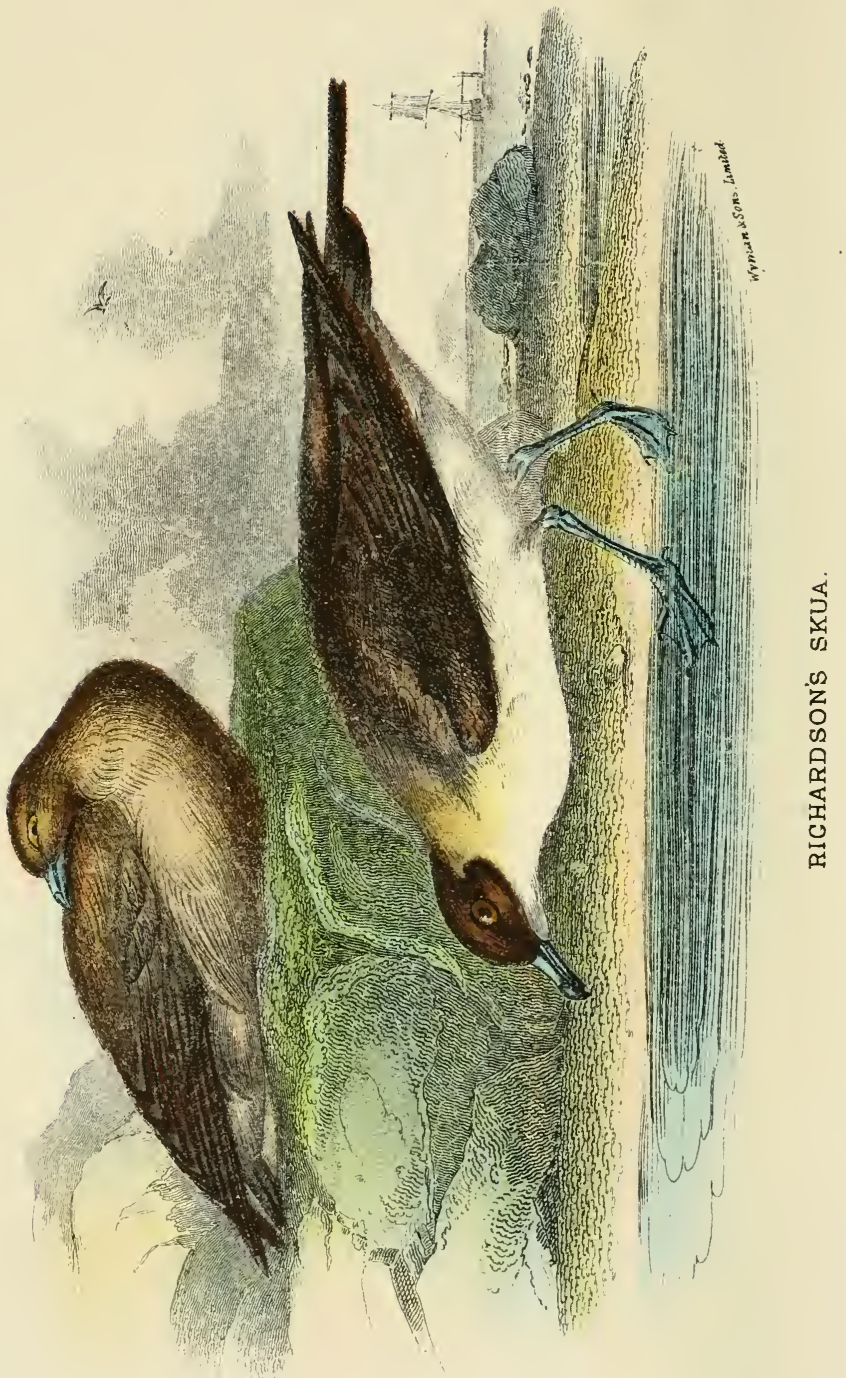


underlying spots are small and indistinct. Axis, $2 \cdot 25^{-2} \cdot 5$ inches ; diam., $\mathrm{I} \cdot 85^{-1} \cdot 75$.

II. RICHARDSON'S SKUA. STERCORARIUS CREPIDATUS.

Larus crepidatus, Banks, in Cook's Voy. Hawksworth's ed. ii. p. I 5 ( I 773).

Lestris richardsoni, Swains.; Macgill. Brit. B. v. p. 492 (1852);

Lilford, Col. Fig. Brit. B. part xxxi. (1896).

Stercorarius crepidatus, Dresser, B. Eur. viii. p. 47 I, pls. 6I I, 6I2, fig. 2 (I876); B. O. U. List Brit. B. p. I95 ( 1883 ) ; Saunders, ed. Yarrell's Brit. B. iii. p. 674 (I884); id. Man. Brit. B. p. 675 (I889).

Stercorarius richardsoni, Seebohm, Hist. Brit. B. iii. p. 353 (1885).

\section{(Plate CIII.)}

Adult Male (Pale Form).-General colour above dark slatybrown, the wing-coverts like the back; bastard-wing, primarycoverts and primaries blackish, with yellowish-white shafts, light ashy-brown on the inner web, with a little white at the base of both webs; tail slaty-brown, blacker towards the end of the feathers, the two centre feathers much elongated; crown of head darker slaty-brown, forming a cap, with a line of white at the base of the forehead; lores and feathers under the eye slaty-brown, blacker in front of the eye; remainder of sides of face and sides of neck white, as well as a collar round the hind neck, with a tinge of straw-yellow; the hind neck and upper mantle light ashybrown, with white shaft-lines; under surface of body white, with a shade of ashy-brown on the fore-neck, darker and more distinct on the sides of the breast and sides of body, and again darker on the under tail-coverts, with white shafts and bases to the latter feathers; under wing-coverts and axillaries dark slaty-brown; "bill horn-colour; tarsi bluish in life, drying olivaceous; toes black" (H. Saunders). Total length, 20 inches; culmen, $\mathrm{I}^{\circ} 55$; wing, 12.3 ; tail, 5.5 ; long centre feathers, $7 \cdot 85$; tarsus, $x \cdot 75$.

Adult Female.-Similar to the male. Total length, $\mathbf{1 9} 3$ inches; wing, $12 \cdot 8$. 
Adult in winter Plumage.-Mr. Saunders describes this phase of plumage as being similar to that of S. pomatorhinus, the winter dress resembling that of summer, but having a tendency to show striations upon the under parts, and especially on the flanks, while the yellow on the neck is less pronounced.

Dark Form.-On the melanistic birds of the present species Mr. Saunders gives the following note:- "The dark-breasted form is rare to the northwards of lat. $70^{\circ}$, beyond which the white-breasted one is the representative form; but southward, both races are found. The colour has no relation to sex, and dark and light birds are constantly to be found paired. The offspring of this union, when adult, is intermediate in character, having a dusky-whitish throat, more or less of an ash-brown band across the breast, and a considerable amount of brown on the flanks. Individuals irregularly spotted with white are not very rare."

Young.-Mr. Saunders describes the offspring of two whitebreasted birds as pale cinnamon-brown on the head and under parts, with dark streaks and bars; the feathers of the upper parts umber-brown, with rufous edges. The offspring of two dark birds is much darker, with greyer tips to the feathers; while the offspring of one white-breasted bird and one sootybird is intermediate, as might be expected. The tarsi and bases of the toes are yellowish, and the front portion of the toes is black.

Immature birds are streaked and mottled with various shades of brown on the upper surfaces; mantle chiefly umber; upper tail-coverts barred with dark brown, white, and rufous; under surface more or less barred with brown on a paler ground (Saunders).

Nestling.-Sooty-brown above, paler on the under surface, the nestlings of dark parents being more dusky than those of the white-breasted ones.

Characters. - The adult of Richardson's Skua is distinguished from that of the Pomatorhine Skua by its smaller size, the wing being less than fourteen inches, and by its long and tapering central tail-feathers, which often project three inches beyond the others. 
From $S$. parasiticus, the present species is distinguished by its comparatively longer bill and by the white shafts to the primaries, whereas $S$. parasiticus has only the two outer primaries white-shafted. The young birds can be told from you "g $S$. pomatorhinus by their smaller size, but it is difficult to distinguish the young of $S$. crepidatus and $S$. parasiticus.

Range in Great Britain.-Richardson's Skua breeds in the Shetland and Orkney Islands, as well as in Sutherland and Caithness, whilst it is also found nesting in the Hebrides. During migration it occurs on both the Scottish coasts, but more frequently occurs on the east coast of England than on the west coast. It also visits Ireland at intervals.

Range outside the British Islands.-The present species breeds throughout the Arctic and sub-Arctic regions of both hemispheres, its Scottish habitat constituting its southern limit. In winter Richardson's Skua extends its range to the southern oceans, having been recorded from the Cape of Good Hope, the shores of the Persian Gulf, the Indian Ocean, and as far as Australia and New Zealand, while it has also been noted from as far south as Rio de Janeiro in South America.

Habits.-The habits of all the Skuas, or Jaegers, as they are called by American naturalists, are very much the same. The following account of Richardson's Skua on the island of Kolguev has been published by Mr. A. Trevor-Battye:-

"Although greatly dependent when at sea upon the labours of other Gulls, the breeding pairs are as persistent robbers of eggs as Rooks in a dry season, and may be constantly seen quartering the tundra for eggs or young. I should be inclined to estimate that of breeding birds on Kolguev there is about one pair to every seven square miles of country. We never found a colony, nor even two pairs together. All those I saw belonged to the light-coloured race. On June 29 we took eggs about incubated. A nest containing one egg (July 7), was a simple depression in dry grass : the egg had a remarkable escape. We were driving along-four sleighs, which meant eighteen reindeer-when I called out to my companion Hyland, who was in front, to stop; for, some thirty yards or so away, a pair of Skuas were behaving as though they had a nest. However, we could make nothing of it, and had just 
taken our seats again to start off, when, as I stooped down to disengage the hind leg of one of my deer, lo and behold, there was a nest under my sleigh. The whole train of sleighs had passed over this nest, and yet the single egg was not broken. On August 7 we picked up a young Skua and brought it back alive. This bird was almost full-grown, and had well-developed primaries. Its parents showed no anxiety about it. It was beside a lake, and as we approached, ran and hid in some grasses. It bit viciously, but made no noise."

"I never in any single instance knew an Arctic Skua to stoop at a visitor near its nest. On the contrary, an intrusion was met by every wile of allurement. It was the old game of 'hot or cold; ' until at last, when you stood close to the nest, both the birds were reduced to a state of helplessness. At such a time they behaved exactly alike. Sitting on their tails, either in the water or on the grass, and beating forwards with their wings, they mewed all the time like cats."

I have taken the following notes from Mr. E. W. Nelson's "Report on Collections from Alaska":- "During summer these Jaegers show a much greater preference for marshes and the low barren grounds so common in the north than they do for the vicinity of the sea-coast. At the Yukon mouth and near Saint Michael's they arrive with the first open water, from the roth to the I $5^{\text {th }}$ of May. The snow still lies in heavy drifts on most of the open country, but the Jaegers take possession and feed upon the Shrew-mice and Lemmings which are common on this ground. By the last of May they are very common, and twenty or thirty may be seen in a day's hunt.

"The young are on the wing by the end of July and early August. The last birds move southward, or keep out to sea, after the 2 oth of September. On cloudy days, or in the dusky twilight, these birds have a habit of uttering loud wailing cries, interspersed with harsh shrieks, which are among the most peculiar notes heard in the northern breeding-grounds. At all times the Jaegers are given to wandering, and one is likely to find then almost anywhere along the coast. They are not infrequently seen harrying Terns or Gulls to make them disgorge fish just caught. If successful, they dart down, and rising under the falling morsel catch it in their capacious mouth. 
This robbery is often performed by two birds in unison, but whether the birds alternate in disposing of the spoil or not could not be learned. When a Jaeger is wounded, others of its kind show much concern, and I have secured several birds in succession which were drawn within range by the cries and struggles of their companions. The habits in general of this and the following species are extremely similar along the coast region of Bering Sea, and both breed abundantly on all that broad belt of low barren plains and marshy country bordering the coast along the entire northern end of the continent. When surprised near its nest it creeps along the ground with flapping wings to decoy away the intruder."

Nest.-As a rule, a depression in the moss, but Mr. TrevorBattye found one in Kolguev which was among dead watergrass in a bog, and was more than a mere depression, for grasses had been walled into the lining.

Eggs.-Two in number. Ground-colour dark chocolatebrown varying to light clay-colour, the darker eggs more strongly marked with deep brown or blackish, the spots being distributed over the greater part of the egg, and the grey underlying markings very indistinct. The jale eggs have the spots collected round the larger end, the rest of the egg being rather free from markings. Axis, $2 \cdot 3-2 \cdot 55$ inches; diam. $1 \cdot 5-1 \cdot 65$.

III. BUFFON'S SKUA. STERCORARIUS PARASITICUS.

Larus parasiticus, Linn. Syst. Nat. i. p. 226 (i 766).

Lestris parasitica, Macgill. Brit. B. v. p. 503 (I852).

Stercorarius parasiticus, Dresser, B. Eur. viii. p. 48 I, pl. 6I 2,

fig. I (1876); B. O. U. List Brit. B. p. I95 (I883); Saunders, ed. Yarrell's Brit. B. iii. p. 68I ( 1884$)$; id. Nan. Brit. B. p. 677 (1889).

Stercorarius buffoni, Boie; Seebohm, Hist. Brit. B. iii. p. $35^{S}$ (I 885).

Lestris parasiticus, Lilford, Col. Fig. Brit. B. part xxxii. ( 1896$)$.

Adult Male.-General colour above slaty-grey, the wing-coverts and scapulars like the back; bastard-wing, primary-coverts and 
quills blackish, the latter browner on the inner web; the first two primaries with white shafts; the innermost secondaries grey like the back; tail-feathers slaty-grey, blackish towards the ends; crown of head black, forming a cap; the lores and sides of face up to the fore-part of the eye blackish, as also the fore-part of the cheeks at the base of the lower mandible; rest of the sides of the face and a collar round the hind neck white, washed with ochreous-buff; throat and fore-neck and chest white, with more or less of an ochreous tinge; remainder of under surface of body from the chest downwards pale slatygrey, including the under tail-coverts, under wing-coverts, and axillaries; "bill horn-colour; tarsi bluish in life, drying olivaceous; toes black" (H. Saunders). Total length, 2 I inches; culmen, $I^{\cdot} \mathrm{I}$; wing, II.8; tail, $4^{\circ} 6$; centre tail-feathers, II ${ }^{\circ}$; tarsus, $1 \cdot 65$.

Adult Female.-Sinilar to the male in colour, but with slightly shorter central tail-feathers.

Adult in winter Plumage.-Similar to the summer plumage, but as in the other species, there is, according to Mr. Saunders, a tendency, after the autumnal moult, to show striated feathers on the flanks, and on the upper and under tail-coverts.

Immature Birds.-Differ from the adults in having very little yellow on the sides of the neck, and in having the under parts and upper tail-coverts barred with varying degrees of ash-brown. The young are ash-brown above, the head darkest, the feathers of the mantle and tail-coverts merely tipped with buff, but without any rufous tint, the under parts being dull greyishwhite, barred with ash-brown (Saunders).

Nestling.-Greyish-brown above and below, much paler and greyer than in S: crepidatus.

Characters.-Mr. Saunders points out that in this species there is always a "very characteristic grey tint in all its phases." The adult bird is certainly lighter grey than $S$. crepidatus, from which $S$. parasiticus also differs in its smaller size, comparatively shorter bill, and long centre tail-feathers, which sometimes project to a length of nine inches. Only the two outer primaries have white shafts. 
Range in Great Britain.-An irregular migrant to our waters, principally occurring on the east coasts, more rarely in the Channel and on the west coasts. It has never occurred in Scotland, according to Mr. Saunders, in any numbers, during the cold season, and in Ireland it has been noticed in autumn, and, sparingly, in spring.

Range outside the British Islands.- " High circumpolar regions, seldon breeding south of the Arctic Circle, unless on lofty fells; in autumn and winter migrating southwards as far as the Straits of Gibraltar, as well as to about $40^{\circ} \mathrm{N}$. lat. on the Atlantic side of America, and a little farther on the Pacific side" (Saunders).

Habits. - For a good account of the habits of Buffon's Skua we are indebted to Mr. E. W. Nelson's "Report," a work which I have had much pleasure in introducing to English readers in the course of the present work. He writes:- "This graceful and handsome bird is the most common of the Jaegers on the Alaskan coast and vicinity, and especially about Saint Michael's. They arrive in this vicinity about the 12 th or 15 th of May, but are not numerous until ten days or more later. They are first found quartering the marshes in small parties of from two to six or eight. They have a shrill phěu-phěu-phěu-phěru, uttered while they are flying, and while the birds are quarrelling or pursuing one another the ordinary note is often followed by a harsh quû . At another time they have a rattling $k r-r-r-r, k r-r-r-r, k r-r-r-r$, $k r \grave{i}-k r i-k r i$-kru, the latter syllables shrill and querulous, and sometimes followed by the long-drawn phěu-phěu-phěu in the same tone. They appear to be much more playful than the other Jaegers, and parties of six or eight may be seen pursuing one another back and forth over the marsh. The long, slender tail-feathers and extreme grace on the wing of those birds render them very much like the Swallow-tailed Kite. The mating occurs with a great amount of noisy demonstration on the part of several rivals, but once paired, the birds keep by themselves, and early in June deposit their eggs in a depression on the mossy top of some knoll upon rising ground.

"In one instance, on June r6, while I was securing the eggs of a Macrorliamphus, a pair of these Jaegers kept circling about, uttering harsh screams and darting down within a few 
feet. As I approached the spot where the Snipe's eggs lay, I noticed those birds on a knoll just beyond, but had paid no attention; but as the birds kept leaving me to hover over the knoll and then return to the attack, I examined the spot, and there, in a cup shaped depression in the moss, lay two dark greenish eggs marked with an abundance of spots. During the breeding season these birds and the preceding species have a cunning habit of tolling one away from their nests by dragging themselves along the ground and feigning the greatest suffering. They roll among the tussocks, beat their wings, stagger from side to side, and seem to be unable to fly, but they manage to increase the distance from their starting point at a very respectable rate, and ere long suddenly launch forth on the wing.

"After a successful hunt, the Jaegers of this and the last species alight upon some prominent knoll and sun themselves, their white breasts showing for a long distance. They are very curious at times, and I have called them within gunshot on several occasions by tossing some conspicuous object into the air as the birds were passing. On one occasion I saw a Jaeger swoop down at a Duck paddling quietly on the surface of a pond, and the latter went flapping away in mortal terror, while the Jaeger passed on, probably highly pleased at giving the Duck such a fright.

"Their taste is omnivorous, and they harry the marshes for Mice and Lemmings, and feast upon the dead fish and other animal matter cast up by the sea, or search the hillsides for berries. The arrival of a vessel in their neighbourhood calls them about to secure the offal thrown overboard. The Eskimo say that they eat just what men like, hence the name given them, derived from the word 'yuk,' or 'man.'

"The swiftness and dexterity with which they pursue Gulls and force them to disgorge is a beautiful sight to witness; and while either of the small Terns or Gulls can drive the Jaeger from the vicinity of their nest, the latter robs them of their prey at pleasure. While I was camping at the Yukon mouth a pair of these birds made their haunt in the vicinity of my tent and fed upon the offal thrown upon the ice a few yards from the door. They soon became very familiar, and were always on hand, hovering close overhead when we came in from a hunt. They would stand about within a few yards and watch us with wistful 
cyes, ready to pounce upon any morsel tossed them; and if a fragment was held up in the hand, they would hover a few feet over it, although not daring to come closer. They also soon became used to our shooting, and scarcely noticed it even when near by. Unfortunately our companionship lasted only about ten days, when I broke camp, and so lost the opportunity of gaining their complete confidence. After the first few days they seemed to appropriate the camp, and made a fierce attack upon any others of their kind that chanced to come near."

Nest.-A cup-shaped depression in the moss.

Eggs.-Two in number. Smaller than those of S. crepidatus, rather paler in tint, and more olive, some being light clay-brown. Two in the Seebohm collection in the British Museum are light bluish-green, very sparsely marked, and all the lighter-coloured eggs appear to be less plentifully spotted. Axis, $2^{\circ} 0-2 \cdot 2$ inches; diam. $I^{\prime} 5^{-1} \cdot 6$.

\section{THE AUKS. SUB-ORDER ALC尼.}

The Auks, though outwardly so different from the Gulls, and possessing features in their economy so dissimilar to the latter birds, have nevertheless many characters in common with them, such as the schizognathous palate, the schizorhinal nostrils, the absence of basipterygoid processes, the furcation of the spinal feather-track on the upper back, and the webbed feet. Externally they differ from the Gulls in their squat appearance, their extraordinary diving powers, their close-set plumage, and in the manner of nidification and the shape of the eggs. They also have a double moult in the year.

The Auks are all birds of the northern hemisphere, breeding in the arctic and sub-arctic regions. They wander south in winter, but are never found to the south of the equator. Some of them, such as the Puffins, have ornamental plumage in the shape of brightly-coloured crests and tufts of feathers on the sides of the head, as well as an ornamental colour on the bills, which is shed after the breeding season, just as other birds moult their feathers. 


\section{TIIE TRUE RAZOR-BILLS. GENUS ALCA.}

$$
\begin{gathered}
\text { Alca, Linn. Syst. Nat. i. p. } 2 \text { 1о ( } 766) \text {. } \\
\text { Type, A. torda, Linn. }
\end{gathered}
$$

The Razor-bills belong to the group of Auks which have a sulcated or grooved bill and exposed nostrils, the latter not being encroached upon by the feathering of the base of the bill, as is the case with many genera of the family. In the case of the Razor-bills the nostrils are exposed, and situated at the end of a triangular base on the mandible, but they are not separated by a ridge from the feathers which encroach on the base of the bill, though there is a swollen ridge at the base of the lower mandible, anterior to the nostril. The Great Auk is merely a gigantic form of Razor-bill, with a heavier body and feebler wings than its more active congener, Alca torda, so that while the latter survives to the present day in thousands, the Giant Razor-bill, as the "Great Auk" ought more properly to be called, has succumbed to circumstances and become extinct.

In addition to the characters given above, the Razor-bills differ from the Great Auk (infrà, p. III) in the possession of fully developed wings, which reach nearly to the end of the tail. They have also well-marked grooves on the bill.

The typical species, $A$. torda, is the only representative of the genus at the present day.

\section{THE RAZOR-BILL. ALCA TORDA.}

Alca torda, Linn. Syst. Nat. i. p. 2 10 ( 1766$)$; Dresser, B. Eur. viii. p. 557, pl. 619 (1877); B. O. U. List. Brit. B. p. 205 ( $\mathrm{I}_{83}$ ) ; Saunders, ed. Yarrell's Brit. B. iv. p. 55 (1884); Seebohm, Hist. Brit. B. iii. p. 375 (1885); Saunders, Man. Brit. B. p. 679 (1889); Lilford, Col. Fig. Brit. B. part xii. (1890).

Utamania torda, Linn.; Macgill. Brit. B. v. p. 346 (I 852 ).

\section{(Plate CIV.)}

Nestling.-Covered with dense sandy-brown down, mottled with black bases to the feathers; the crown of the head and sides of face and neck more hoary-grey; cheeks and throat 



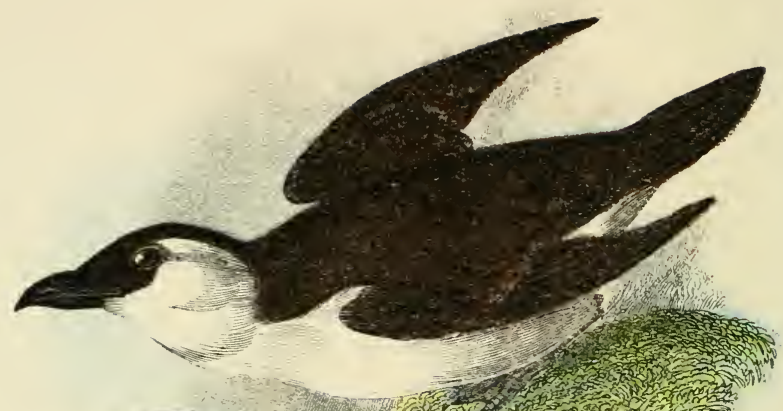
rost

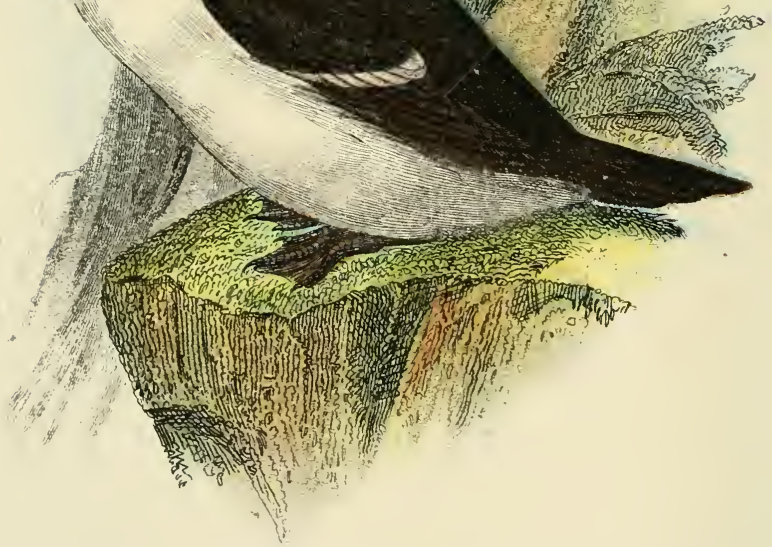

RAZOR-BILL 
blackish ; lower throat and rest of under surface of body dull whitish ; sides of body like the back.

The first plumage, after the downy stage, is black above, including the sides of the face and sides of neck, the black extending across the lower throat; under surface of body white, the lower flanks with dusky tips; along the upper edge of the lores is a very narrow line of white; the bill is black, very narrow, and shows a white "nail" on the end.

Adult Male-General colour above black, including the wings and tail, the secondaries tipped with white, forming a band; entire sides of face and sides of neck velvetybrown, occupying the upper part of the throat, but extending in a well-defined line down the sides of the latter across to the sides of the upper breast, leaving the white of the lower throat and fore-neck to end in a blunt triangle; entire under surface from the lower throat downwards, pure white, the fore-part of the tibia brown; under wing-coverts and axillaries white; a distinct line of white running from the base of the culmen along the upper lores to the middle of the eye; "bill black, with a curved transverse white line in the centre on each side; legs, feet, and claws brownish black; iris hazel" (Seebohm). Total length, I 5 inches; culmen, I'4; wing, $7 \cdot 3$; tail, $3 \cdot 0$; tarsus, $\mathrm{r} \cdot 2$; middle toe and claw, $\mathrm{I} \cdot 8$.

Adult Female.-Similar to the male. Total length, $\mathrm{I} 6$ inches; wing, $7 \cdot 2$.

Adult in Winter Plumage.-Similar to the summer plumage as regards the upper surface, but having no blackish brown on the throat; the feathers of the lores dark brown, extending backwards in a band below the eye across the ear-coverts; area behind the eye white, extending over the sides of the neck, and including the whole of the cheeks and the entire throat and under surface of the body; the white line along the upper edge of the lores very indistinct, but still traceable; the bill with ridges and the transverse white line.

Young in Winter Plumage.-Similar to the adult in winter plumage, but always to be distinguished by its smaller and narrower bill without vertical ridges; the white loral line is either obsolete or scarcely traceable. 
Seebohm says that, after the first spring moult, the adult nuptial plumage is almost completely assumed, but the bill, although presenting the white transverse stripe, has only two, instead of the three, transverse grooves which characterise the old bird.

Range in Great Britain.-An inhabitant of the rocky coasts, nesting in such localities from Cornwall to the Shetlands. It also breeds on the Channel Islands. With regard to Ireland, Mr. Ussher remarks that it "breeds usually in great numbers on cliffs off the coasts and islands of Donegal, Antrim, Dublin, Wexford, Waterford, Cork, Kerry, Clare, Galway, Mayo, and Sligo." In winter it is found in the British seas, and is occasionally driven far inland during stormy weather.

Range outside the British Islands.-The Razor-bill is an inhabitant of the Atlantic Ocean, occurring on the shores of North America on the Atlantic, but not on the Pacific, shores. It breeds in Norway up to $69^{\circ} \mathrm{N}$. Lat., as well as in the Faeroes and Iceland, probably in Jan Mayen Island, but not, so far as is known, in Spitsbergen. Its most southern breeding range, according to Saunders, is the coast of Brittany; though in winter it is seen in the Mediterranean, and even as far as the Canaries. It is found in Eastern North America, breeding in Greenland up to about $70^{\circ} \mathrm{N}$. Lat., and on the coasts of Labrador, Nova Scotia, and Newfoundland, wintering somewhat to the south of these countries, when it occurs off the New England coast.

Habits.-Very similar to those of the Puffin and Guillemot, the species being equally gregarious both in summer and winter. It is met with on the Farne Islands, where, however, it is not very plentiful. My friend, the late Henry Seebohm, has written some interesting accounts of the birds observed by him in the last-named islands, and I quote the following from his " History of British Birds":-

"Like the Guillemot and the Puffin, the Razor-bill is a resident in the British seas, but appears to be less numerous in winter than in summer, because it is spread over a much wider area, and lives for the most part out at sea. In its habits it very closely resembles the Guillemot, but is easily distinguished from that bird, even at a considerable distance, by its deeper 
bill and conspicuous stripe from its base to the eye. It is gregarious at all times of the year, and in some places literally swarms. In summer it comes to the rocky headlands and wild precipitous islets to rear its young; but from its partiality for clefts in the rocks rather than ledges, it is almost absent from many places where the Guillemot breeds in great abundance, as, for instance, the 'Pinnacles' in the Farne Islands. The Razor-bill is most at home in the water, where it vies even with the fish in activity and rapidity of movement. It floats on the heaving waves, light and buoyant as a cork, sitting well out of the water, its head and neck raised high above its back, very similar to a Duck or a Diver. It swims with ease, paddling at times very quickly, and often indulges in a frolic in the sea, splashing about with its wings, chasing its companions, and being chased by them in turn. It often sleeps on the water, tossed about seemingly at the mercy of the waves, but quite safe even in the roughest water. It is by no means a shy bird, and frequently allows a boat or a vessel to approach it within a few yards ere it takes wing or dives. Like the Guillemot and the Puffin, it is an expert diver, vanishing from view with great rapidity, leaving tiny air-bubbles to mark the place of its descent. It dives for a considerable distance below the surface, either in pursuit of a small fish or in search of crustaceans and molluscs hiding in the crevices of the rocks and amongst the seaweed at the bottom. The Razor-bill, in spite of its narrow and comparatively small wings, flies well, but does not rise very easily from the water, generally splashing along for a few yards ere it gets well into the air. It never appears to fly about like the Puffin, and when it leaves its perch on the rocks generally darts headlong down into the sea, and, when leaving the water, soon makes for the rocks again. The flight is performed by rapid and incessant beatings of the wings. The Razor-bill is a clumsy object on the land, and very rarely attempts to walk far, progressing in a hobbling kind of way. This bird often goes long distances to feed, and then its flight can be seen to perfection, as the little troop of birds, usually in single file, pass rapidly along just above the surface of the waves.

"The food of the Razor-bill is composed principally of small fish, especially of the fry of the herring and the coal-fish; these 
are often pursued under the water with as much dexterity as the Swallow chases an insect in the air. The Razor-bill flies under the water aided by its webbed feet; it is capable of remaining under the surface for a long time, and when submerged not only catches fish, but searches for crustaceans, molluscs, \&c. The note of this bird, which is rarely heard, may be described as a low croaking sound."

Nest.-None. The Razor-bill places its eggs on the rocks, but always, if possible, in some niche or crevice, sometimes far out of reach, and seldom in the open, though Saunders once saw an old Cormorant's nest appropriated by a Razor-bill. Both male and female incubate.

Egg.-One only, differing in shape from that of the Guillemot, and the extraordinary variation in colour is not so marked as in the eggs of the latter bird. A reliable test for their identification consists in the fact that, when the egg of the Razor-bill is held up against the light, and looked at through the blowinghole, the inside always appears grcen, whereas the inside of a Guillemot's egg generally appears to be yellowish-green, though greenish eggs of the latter bird have often a pervading tint of green reflected through by the external colour of the egg. Mr. Robert Reail writes :- "The Razor-bill lays its eggs on the bare rock, without any sign of a nest, like the Guillemot. The eggs are, however, usually placed in more sheltered positions than those of the latter bird, such as in a corner or hollow among the rocks, or under a projecting boulder. Some of the eggs with the red ground-colour are very handsome, but I have found them mingled with those with white and every intermediate shade of ground-colour on the same rocks. Some varieties of the Razor-bill's eggs are not easy to distinguish from those of the Osprey."

\section{THE GREAT AUKS. GENUS PLAUTUS.}

Plautus, Brünn. Zool. Fund., p. 78 (1872).

Type $P$. impennis (Linn.).

Only a single species of the genus Plautus is known. Once plentiful within a limited latitude, it has become extinct within the present century, and, in spite of hopes that some indi- 
viduals might yet survive, year after year passes by without the discovery of a living specimen. That the species was extinguished by the agency of man there can be little doubt. Professor Alfred Newton writes in his "Dictionary of Birds":"In Iceland there is the testimony of a score of witnesses, taken down from their lips by one of the most careful naturalists who ever lived, the late John Wolley, that the latest survivors of the species were caught and killed by expeditions expressly organised with the view of supplying the demands of caterers to the various museums of Europe. In like manner the fact is incontestable that its breeding-stations in the western part of the At'antic were for three centuries regularly visited and devastated with the combined objects of furnishing food or bait to the fishermen from very early days; and its final extinction, foretold in 1792 by Cartwright ('Labrador,' iii. p. 55), was due, according to Sir Richard Bonnycastle ('Newfoundland, in $I 8_{42}$,' i. p. 232$)$ to 'the ruthless trade in its eggs and skin.' No doubt that one of the chief stations of the species in Icelandic waters disappeared through volcanic action-

\section{'A land, of old upheaven from the abyss \\ By fire, to sink into the abyss again.'}

and that the destruction of the old Geirfuglaskér drove some, at least, of the birds which frequented it to a rock nearer the mainland, when they were exposed to danger from which, in their former abode, they had been comparatively free; yet, on this rock (Eldey = fire-island) they were 'specially hunted down' whenever opportunity offered, until the stock there was wholly extirpated in $\mathbf{1} 844$, and whether any remained elsewhere must be deemed most doubtful."

The Great Auk was a gigantic flightless Razor-bill, with such small wings - only about the size of the ordinary Razor-billsthat it was unable to fly. Bullock, who saw a specimen alive, say's that it was "wholly incapable of flight, but so expert a diver that every effort to shoot it was ineffectual."

I. THE GREAT AUK. PLAUTUS IMPENNIS.

Alca impennis, Linn. Syst. Nat. i. p. 2 10 (г766); Macgill. Brit. B. v. p. $359(1852)$; Dresser, B. Eur. viii. p. 563, 
pl. 620 (1880); B. O. U. List Brit. B. p. 206 (I883); Saunders, ed. Yarrell's Brit. B. iv. p. 6r (1884); Seebohm, Hist. Brit. B. iii. p. 37 I (1885); Saunders, Man. Brit. B. p. 68 I (I889); Lilford, Col. Fig. Brit. B. part xviii. (I89I).

\section{(Plate CV.)}

Adult in Summer Plumage.-General colour above glossy black ; wings like the back; quills brownish black, the secondaries tipped with white, forming a white bar; tail also black; head and neck glossy black, like the back; the throat rather more brownish black; under surface white, sharply defined from the black of the back, ascending on to the throat and forming a triangular patch ; sides of body dove-grey; a large white patch on each side of the head in front of the eye. Total length, $25^{\circ} \circ$ inches ; culmen, $3^{\circ} 6$; wing, 6.0 ; tail, $3^{\circ} 8$; tarsus, $x \cdot 8$.

winter Plumage.-As in the Razor-bill, the throat is white in winter.

Range in Great Britain.-The Great Auk used to breed in $\mathrm{S}$. Kilda, but even by the middle of the last century the birds had become very irregular in their visits.* A male and female were killed at Papa Westray, one of the Orkneys, in I 8 r 2. The male bird of this pair is now in the British Museum. In August of 182 I or 1822 , Fleming records a specimen sent to him from S. Kilda, and, according to the researches of Mr. Henry Evans, a bird of this species was captured in the same group of islands about the year I 840 . That the Great Auk formerly had a more extended range in ancient times has been proved by the remains which have been found in Caithness and Argyll, and even as far south as some old seacaves in Durham (cf. Saunders, Man. p. 682). Mr. BarrettHamilton has collected the evidence of the existence of Plautus impennis in Ireland, where Mr. W. J. Knowles has found remains of the species on the coast of Antrim, along with those of the horse, dog, or wolf, "in conjunction with human remains believed to be those of the earliest Neolithic

* For an epitome of the range and habits of the Great Auk, I am indebted to a pamphlet written by Mr. Thomas Parkin, and to Mr. Howard Saunders' "Manual." 



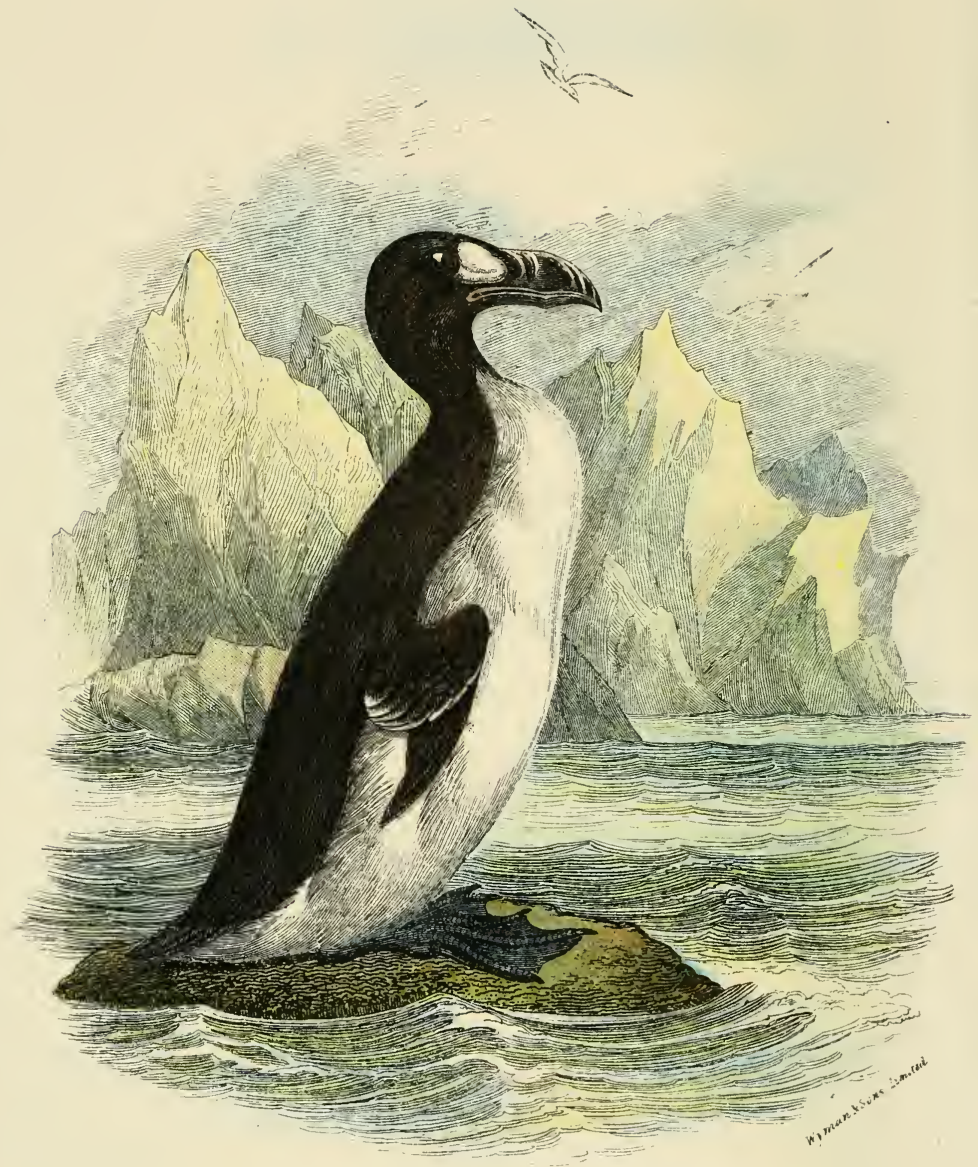

GREAT AUK. 
inhabitants of Ireland." Two other specimens were taken near the entrance of Waterford Harbour in May, I834. Three other instances of the capture of the Great Auk have been recorded by Thompson, but confirmatory evidence is lacking.

Range outside the British Islands.-Iceland seems to have been the last known resort of the present species, which appears at no time to have been an Arctic bird. Its bones have also been discovered in the kitchen-middens of Denmark, and the remains of the species discovered on Funk Island, off Newfoundland, have been considerable.

Habits.- The scanty notes on the habits of the Great Auk are derived from the accounts of early voyagers. Although incapable of flight, its diving powers are admitted to have been extraordinary. Like other flightless birds, it seems to have been stupidly tame in its disposition, and this fact alone accounts for its rapid extermination. The bird captured off Waterford actually approached the boat for food, and was apparently in a starving condition. "For some days after its capture it ate greedily of potatoes mashed in milk. After keeping it for ten days, it was sold to Mr. Davis, who sent it to Mr. Gough, of Horetown, co. Wexford. Singularly, for about three weeks after its transference to its new home, it was not known to eat anything. Mr. Gough, fearing it would succumb, caused potatoes and milk to be forced down its throat, and from that time it ate voraciously until within a day or two of its death. It died a little over four months after its capture. When in Mr. Gough's possession, its principal food was trout and other fresh-water fish, which it seemed to prefer to fish from the sea. It swallowed the fish entire. (Parkin, "The Great Auk or Gare-fowl," p. 6, r 894.)

Nest.-None, the single egg being laid on a rock.

Eggs.-One. The eggs of the Great Auk may be described as those of a gigantic Razor-bill, going through the same kind of varieties as in the latter species, but, of course, greatly exceeding the Razor-bill's egg in size. The number of Great Auk's eggs in various museums and private collections is seventy-one, as I am informed by Mr. Edward Bidwell, who has personally examined nearly all the specimens. 
THE GUILLEMOTS, GENUS URIA.

$$
\begin{gathered}
\text { Uria, Briss. Orn. vi. p. to ( } 760 \text { ). } \\
\text { Type U. troile (Linn.). }
\end{gathered}
$$

In the true Guillemots there are no sulcations on the bill and no wattles on the face. The bill is compressed and slender, sometimes rather long, its length from the gape equal to or exceeding that of the middle toe and claw; the nasal aperture is hemmed in with close-set plumes, extending to the upper shelf of the nostril.

\section{THE COMMON GUILLEMOT. URIA TROILE.}

Colymbus troile, Linn. Syst. Nat. i. p. 220 (1766).

Uria troile, Macgill. Brit. B. v. p. 318 (1852); Saunders, ed. Yarrell's Brit. B. iv. p. 69 (1884) ; id. Man. Brit. B. p. 683 (1889) ; Lilford, Col. Fig. Brit. B. part xxi. (1892).

Alca troile, Dresser, B. Eur. viii. p. 567 , pl. $62 \mathrm{r}$ (1877); Seebohm, Hist. Brit. B. iii. p. 388 (1885). Lomvia troile, B. O. U. List Brit. B. p. 206 (1883).

\section{(Plate CVI.)}

Adult Male in Summer Plumage.-General colour above smokybrown, the head, neck, and throat paler and more earthy-brown, the rest of the upper parts being gradually darker; wings like the back, the secondaries tipped with white, forming a bar; under surface of body white from the lower throat downwards, the line of demarcation passing obliquely downwards to the sides of the back; the sides of the body and flanks streaked with sooty-grey, the feathers being edged with this colour; thighs brown; the under wing-coverts white, the lower primary-coverts ashy; quills dusky-brown below, whitish towards the base of the inner web; bill black; legs and feet olive; irides hazel. Total length, I $7^{\circ} \circ$ inches; wing, $7^{\circ} 9$.

Adult in winter Plumage.-Differs from the summer plumage in having the throat white like the rest of the under surface; the cheeks also white, as well as the sides of the neck from just behind the eye ; the lores, feathers round the eyes, and a broad streak along the top of the ear-coverts, black. 
Young in winter Plumage.-Seems to resemble the adult at the same time of year, but the white on the fore-neck is mottled with blackish fringes to the feathers, those of the hinder part of the white band on the side of the head being also freckled with black.

Nestling.-General colour above dusky chocolate-brown, the head and neck like the back, but covered with hair-like white down; cheeks white, streaked with black; under surface of body pure white, the throat slightly freckled with dusky margins to the feathers; sides of body dusky-brown, the flanks with a white patch, and another white patch on each side of the rump.

Range in Great Britain.-The Guillemot frequents the same localities as the Razor-bill, but is more plentiful than the latter bird. It is found breeding on all suitable cliffs throughout the British Islands, Flamborough Head being one of the best-known localities for the species. Mr. Ussher says that, in Ireland, it "breeds in great colonies on the sea-cliffs, usually in the vicinity of those of the Razor-bill, but on more open ledges and platforms." The same counties may be enumerated as in the case of the Razor-bill, with the exception of Waterford.

Range outside the British Islands.-The present species is found in great numbers in Iceland, and the Faeroes, and up to the Varanger Fjord in Norway, and even to Bear Island. It breeds on Bornholm in the Baltic, and a small colony inhabits the northern end of Heligoland during the summer. Colonies are also found on the northern and western coasts of France, and the most southerly breeding-place is off the coast of Portugal, where Mr. Tait has found and obtained eggs from the Berlengas Islands off the mouth of the Tagus. In North America it breeds from New England down to about $64^{\circ} \mathrm{N}$. Lat., and in the Atlantic it is found as far south as $30^{\circ} \mathrm{N}$. Lat. in winter, but appears seldom to enter the Mediterranean. The Guillemot of the Pacific coasts is supposed to be a distinct species, and is known as $U$. californica, but I cannot find sufficient evidence to separate this bird specifically from $U$. troile. At first sight the bill seems to be somewhat different, appearing rather stouter, with the angle of the genys more acute, and the flanks have the brown streaks more plainly indicated. Among the European specimens, however, in the British Museum, I find certain 
individuals which match the IVestern American ones in every respect, and I do not consider that the two races can be separated.

Habits.-Although the Guillemot returns to its breeding stations in vast numbers in the summer, I believe that there are many individuals that do not breed at all, for I have seen plenty of them in June at least one hundred miles from land, swimming about in the middle of the sea, and resting on the water in the laziest manner. In calm weather they even sleep in the middle of the summer's day, so that on more than one occasion the bow of the steamer was upon then ere they hurriedly woke up and dived to a safer distance.

I quote Seebohm's account of the habits of the Guillemot on the Farnes. He had in his possession some beautiful paintings of the bird-life on these islands, and the journals of his visits to this locality were always very interesting reading. He describes the nesting of the Guillemot as follows :-

"For the greater part of the year the Guillemot's haunt is the open sea; but in the breeding season it retires landwards to its favourite cliffs and rocky islets. A nursery of these birds presents one of the most interesting phases of bird-life. Whether it be the brave old headland cliffs of Flamborough Head and Bempton, the curious 'Pinnacles' at the Farnes, the rugged coasts of Wales, the innumerable nurseries on the Scottish rocks and islets, or a 'fuglevœr' among the Norwegian Fjords - all possess abundant attractions for the naturalist, and well repay repeated visits.

"So soon as the breeding-season has passed, even before the young birds have fully gained the use of their wings, the Guillemots forsake the cliffs and spend the rest of the year upon the open sea. A rocky shore is now no more attraction to them than a low and sandy one, and they may be frequently seen in the sea off such low-lying coasts as those of Lincoln and Norfolk. The Guillemot is to some extent a migratory bird, but is, perhaps, better described as a wandering one, straying hundreds. even thousands, of miles from its breeding-place and its true home. Certain it is, we know on good authority, that the birds are never seen on the cliffs at Flamborough or at the Farnes for several months after the young are reared. On Heligoland the 

ए

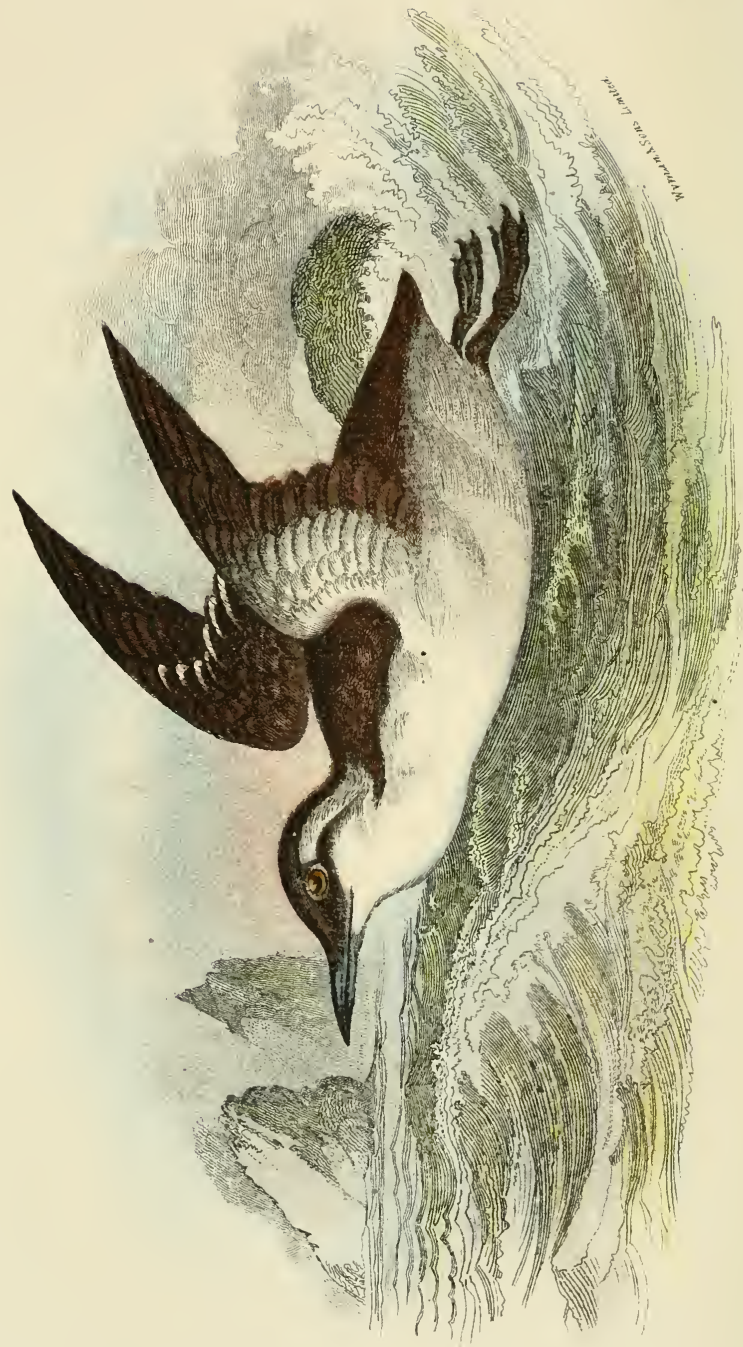

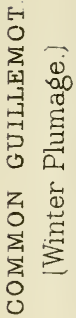


birds reappear during the months of November and December, at least half of them being young ones; and in some of the migration-reports the Guillemot is returned as appearing at its breeding-places suddenly, and just as suddenly leaving them again when the duties of the season are over.

"The Guillemot is an expert diver, very often diving so suddenly as to defy the quickest shots, disappearing at the flash of the gun, to rise again at some distance quite unharmed. We have but little opportunity, if any, of observing the bird's aquatic gambols in its own native ocean; but the Guillemots in the salt-water tanks at the Brighton Aquarium are a source of never-ending interest and amusement to visitors. Using their wings much after the manner that a fish does its fins, they progress through the water, darting hither and thither with great rapidity. In swimming, the Gullemot uses its legs as a motor, but in diving the wings alone are used; the whole body of the bird is covered with a mass of air-bubbles, and it leaves a train of these bubbles behind it, glistening like silver and pearls, which adds much to the beauty of the performance. Sometimes the descent of the bird is perpendicular, sometimes in an oblique direction; and its progress under the water is made apparently as easily as through the air, even more so, turning and gliding about with ever graceful movements, and sometimes hovering over a morsel of food like a Tern. The Guillemots at the Aquarium rarely stay under the surface more than half-a-minute; but in the open sea I have known them to remain down for a much longer time.

"The food of the Guillemot is largely composed of the fry of fishes, notably that of the herring; but this fare is also varied by small crustaceans, marine insects, molluscs, and various small fish. This food is often obtained near the coasts, in sheltered bays and estuaries, where the birds congregate in large numbers; but at night they generally go out to the open sea, except during the breeding season. The Guillemot is often caught in the herring nets, and is sometimes taken on the hooks baited with small fishes. It takes its prey, if it be a fish, crosswise, and swallows it after changing its position. The young birds are fed by their parents on portions of fish, and even when they are sufficiently matured to seek the water they are still tended by the old birds. 
"As a rule the Guillemot is a remarkably silent bird; and no matter how large its colony may be, but little or no noise is heard, save the whirr of their short wings as they leave the ledges, and an occasional hoarse guttural note as they struggle for a point of vantage on the rocks. When seriously alarmed, they often utter this note whilst wheeling round an intruder's head; but the Guillemot rarely utters a sound, and allows its eggs to be taken, or its privacy disturbed, without offering any noisy resistance or remonstrance.

"The breeding-season is the time when the Guillemot's habits are most interesting and the easiest to observe. During that period, which commences in May and lasts until August, the birds are confined to the rocky headlands and the isolated rocks. Among the breeding-places of the Guillemot the cliffs at Flamborough and Bempton probably stand unrivalled, so far as the British Islands are concerned; but I know of no place where sea birds can be studied to greater advantage than at the Farnes. I have visited these islands many times, and every time I have been more charmed than before."

Nest.-None, the egg being laid upon the bare rock.

Egg.-One only, pear-shaped. The eggs of the Guillemot are subject to the most extraordinary variation, exceeding, perhaps, that of any other species of bird. The series in the British Museum occupies $\mathrm{x} 3$ cabinet drawers. They principally consist of the specimens presented by the late Henry Seebohm. The types of coloration are so varied that a special description of each becomes difficult. The following varieties are perhaps the most prominent :-

Ground-colour white, sometimes unspotted, the markings few and far between, but sometimes forming confluent blotches.

Ground-colour greenish-blue, with all kinds of irregular spots, blotches, and scribblings, some of the eggs being so thickly mottled as to call to mind a thickly-marked Crow's egg.

Ground-colour greenish-blue, with brown or blackish scribblings only, these being distributed all over the surface, or being congregated at the larger end of the egg.

Ground-colour creamy-buff, thickly or sparsely spotted with chestnut. 



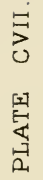

1

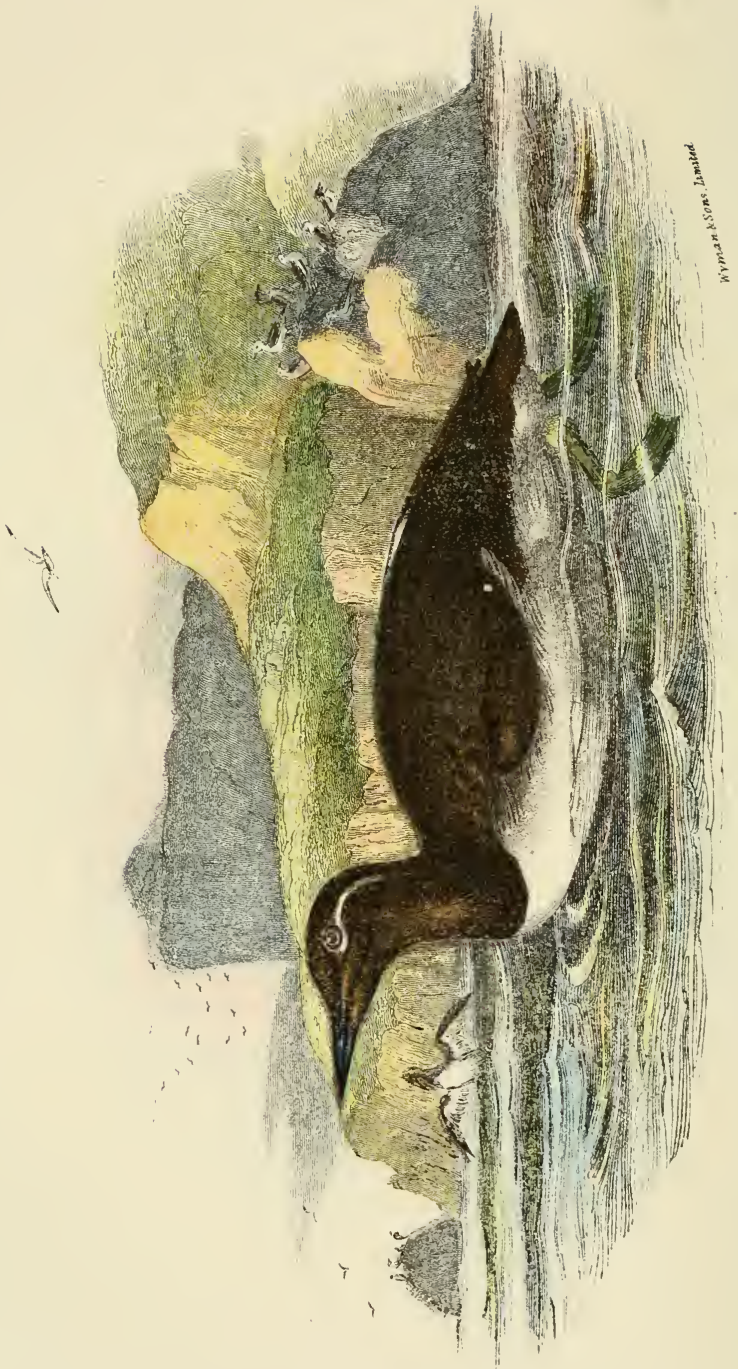

号 
Ground-colour greenish, thickly spotted or clouded with brown or chestnut.

Ground-colour rufous-buff, with large blotches or spots of reddish-brown or blackish.

Ground-colour almost uniform greenish-blue, without spots.

Ground-colour bluish or greenish-white, with blackish spots, dots, or scribblings, often confluent round the larger end of the egg, where there is generally a large black patch, often interspersed with reddish, the grey underlying markings scarcely visible in this type.

Ground-colour creamy-buff, with black or reddish-brown markings, taking the form of a huge blotch at the large end of the egg; or with scribblings and spots universally distributed over the surface, the grey underlying spots being very much in evidence. Axis, $3^{\cdot 0}-3 \cdot 5$ inches; diam. $\mathbf{1}^{\cdot} 55^{-2} \cdot \mathbf{I}$.

II. THE BRIDLED GUILLEMOT. URIA RINGVIA.

Uria ringvia, Lath. Gen. Syn. Suppl. i. p. 295 ( ( 787 ).

(Plate CVII.)

Adult in summer Plumage.-Similar to $U$. troile, but distinguished by the white eye-ring and the white line which runs from behind the eye down the crease which skirts the hinder edge of the ear-coverts. Total length, 15 inches; culmen, 19 ; wing, $7 \cdot 6$; tail, $2 \cdot 0$; tarsus, $\mathrm{r} \cdot 25$.

Adult in Winter Plumage.-Similar to the winter plumage of $U$. troile, but distinguished by the white line behind the eye, which is retained in the winter plumage.

Characters. - Many ornithologists consider the Ringed Guillemot to be a mere variety of the common species, but I cannot quite understand the reason for this conclusion. If the Ringed Guillemot inhabited a perfectly distinct area, I believe that no one would hesitate to consider it a well-marked form, but as it is, on the contrary, found among the colonies of the ordinary Guillemot of our shores, there is some hesitation in recognising it as a distinct species. To me the characters appear sufficiently well marked, the white ring round the eye and the white streak along the crease above the ear-coverts distinguishing the Bridled Guillemot from the ordinary U. troile. Seebohm 
writes: "So far as is known, wherever one form occurs, both in the Atlantic and Pacific, the other is found with it, the proportion of Ringed Guillemots varying from one in five to one in twelve of the Common Guil'emot." He also states that the two forms have been seen paired together, "and the white line behind the eye is said to vary in length, leading to the supposition that intermediate forms are found." In all the specimens as yet examined by me, I have found no trace of such intermediate forms, and the inter-breeding, if such there be, between the Bridled and the Common Guillemot, is no more than one might expect to occur between two species alike in size and habits. Such instances are known to occur in other groups of birds, as is evidenced by the Crows, Dippers, and Wagtails. I confess, however, that I should like to have indisputable evidence that the two Guillemots inter-breed. It seems to me that such satisfactory evidence must be very difficult to obtain.

There is no recorded difference in the habits or nidification of the Bridled Guillemot to those of the Common Guillemot.

III. BRÜNNICH'S GUILLEMOT. URIA BRUENNICHI.

Uria brunnichii, Sabine, Trans. Linn. Soc. xii. p. 538 (I8 18); Macgill. Brit. B. v. p. $314(1852)$; Saunders, ed. Yarrell's Brit. B. iv. p. 76 (I 884 ); id. Man. Brit. B. p. 685 (I889); Lilford, Col. Fig. Brit. B. part xxxii. ( 1896$)$.

Alca bruennichii, Dresser, B. Eur. viii. p. 575, pl. 622 (1877). Lomiia bruennichi, B. O. U. List Brit. B. p. 207 ( 1883 ). Alca troile brunnichi, Seebohm, Hist. Brit. B. iii. p. 388 ( 1885 ).

Adult Male in Breeding Plumage.-General colour above glossy black; the head like the back; the lores, feathers above the eye, sides of face, throat and sides of neck rich chocolatebrown, contrasting with the black of the upper parts; wings black, the secondaries tipped with white, forming a wing-bar; the outer primaries with white bases to the shafts; tail black; under surface pure white, from the lower throat downwards, a sharp line of demarcation crossing to the sides of the chest, and forming a blunt triangle on the lower throat ; under wingcoverts white, those near the edge of the wing light brown; 
lower primary-coverts and inner surface of quills ashy-brown. Total length, 15 inches; culmen, $\mathrm{I}^{\circ} 6$; wing, 8.9 ; tail, $\mathrm{r} \cdot 85$; tarsus, $\mathrm{I} \cdot 4$

Adult in Winter Plumage.-Black above, white below; the lores and sides of the face being blackish, and not chocolatebrown as in the summer plumage, where they are in contrast to the black head; the hinder cheeks and sides of the neck showing a white patch which is more or less mottled with black, as is also the lower throat; the upper throat white, with a black spot on the chin; the swollen base of the cutting edge of the mandible less distinctly marked.

Young.--Resembles the adult in winter plumage, but is whiter on the throat and sides of the neck, these parts not having the black mottling of the adult. A young female obtained by Dr. Stejneger on Bering Island, on the 3 rd of January, had the "bill dark, almost blackish, bluish-grey, with a light spot on the genys in front of the angle; feet light bluish pearl-grey, with a faint yellowish tinge in front (not greenish, however), the joints darker bluish-grey, underneath blackish-grey."

Characters. - The thick bill, with its enamelled appearance near the gape, distinguishes Brünnich's Guillemot from Uria troile at a glance, and I am unable to comprehend Seebohm's conclusion that it is so little recognisable as to be merely a race of $U$.troile. In my opinion $U$. bruennichi is almost generically distinct from $U$. troile, while its blacker coloration, with the contrast between the black head and the deep chocolate-brown on the sides of the face and neck, is most marked. It is thoroughly distinct from $U$. troile as a species. I have been unable to separate Uria arra from U. bruennichi, as is done by the American ornithologists, who insist on its larger size and less swollen tomium. Specimens from Spitsbergen and the Kuril Islands have the tomium equally distinct and the wing of the same length $(8 \cdot 4-8 \cdot 5)$. A Greenland specimen has the wing $8 \cdot 8$ inches.

Range in Great Britain.-Seebohm speaks of Brünnich's Guiliemot as "a very rare straggler to the British Islands in autumn and winter, having been most frequently observed in the Orkneys and extreme north of Scotland," but, he adds, "there can be little doubt that it is often overlooked and con- 
fused with its smaller-billed ally." Mr. Howard Saunders, on the other hand, at the time of writing his "Manual," in I 889, considered that the species had been included in the British List on very slight evidence, and was inclined to admit only two occurrences as worthy of any credit at all. In 1895 , however, identified specimens were obtained from the coast of Yorkshire and from Cambridgeshire.

Range outside the British Islands.-Brünnich's Guillemot is a truly Arctic species, being plentiful in Spitsbergen, Jan Mayen, Novaya Zemlya, and Franz-Josef Land. In Greenland there are abundant colonies, and Colonel Feilden observed the species as far north as Lat. $72^{\circ}$. It is found also on the Pacific side of North America. In winter it visits the coasts of Scandinavia, and has been found on the eastern shores of Great Britain and in the North of France, while in North America it extends as far south as New Jersey.

Habits.-These, as might be expected, are similar to those of the Common Guillemot. In some of its Arctic resorts, incredible numbers of the species are said to congregate in the North Pacific; they are usually called Uria arra, a form which I consider to be inseparable from U. bruennichi. Dr. Stejneger writes: "They pass the winter away from the shores of the islands, probably on the open sea not far from them, as is indicated by living individuals occasionally appearing during the winter, and by the dead bodies regularly cast ashore after each severe storm of the season. About the ist of April, or a little earlier, enormous flocks approach the shore and take possession of the rookeries.

"When breeding, the long rows of 'Ares' * on the narrow shelves of rocks, where they have deposited their manycoloured, large, pear-shaped eggs, face the rocky wall with their white breasts, turning their black backs to the spectator. When flying off the nest, they consequently are compelled to first turn round, and, if taken by surprise, this manouvre will often cause them to throw the egg from the shelf into the water. It happened several times that, when I stealthily approached in a boat under the breeding-colonies, several eggs were thrown into the boat when the birds rushed off their

* So called from their note, ar-r-r. 



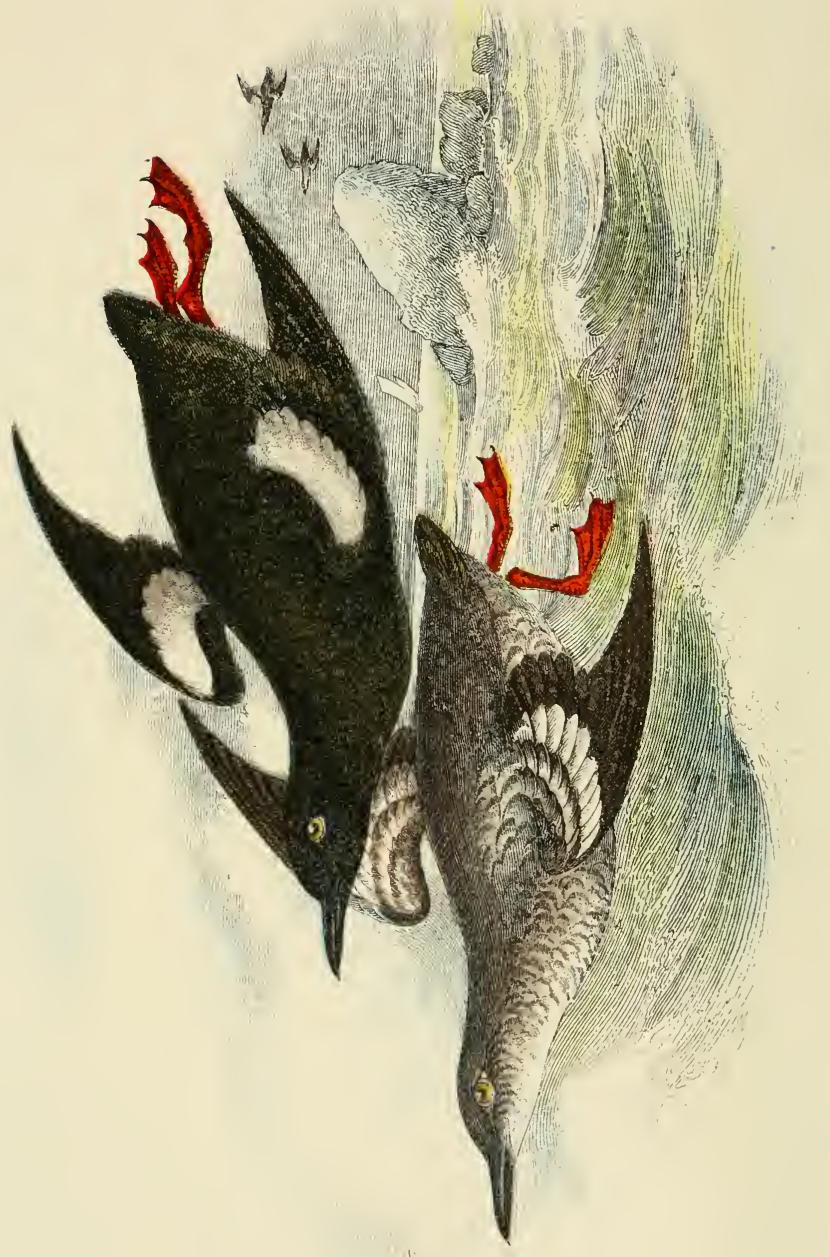

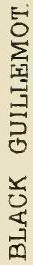


nests, if the bare rock upon which the egg is placed can be called a nest, and my Aleutian oarsmen were always in a roar of laughter when one of these projectiles exploded on the head of an unfortunate comrade." Mr. Trevor Battye informs me that in Spitsbergen he saw this Guillemot swimming about with the young one on its back.

Nest.-None, the single egg being laid upon the bare rock.

Eggs. - Similar to those of the Common Guillemot, and subject to the same variation. Mr. H. J. Pearson visited a colony on Novaya Zemlya, and obtained a series of eggs in July, I 895. He says :- "The series shows great variety in colour and size. In colour they closely resemble a selected collection of the Common Guillemot's eggs, and pass from pure white to the browns of the Razor-bill, with every variety of yellows and blue-greens, some being very handsomely blotched with black."

\section{THE BLACK GUILLEMOTS. GENUS CEPPIIUS.}

Cepphus, Pallas, Spil. Zool. v. p. 33 (г 769).

$$
\text { Type C. grylle (Linn.). }
$$

The genus Cepphus differs from the genus Uria in its shorter bill, the culmen scarcely exceeding the length of the inner toe and claw, in the differences of the summer and winter plumages, and in the significant fact that it lays a couple of eggs instead of one.

\section{THE BLACK GUILLEMOT. CEPPHUS GRYLLE.}

Colymbus grylle, Linn. Syst. Nat. i. p. 220 ( 1 766 ).

Uria grylle, Macgill. Brit. B. p. 33 I $\left(\mathrm{x}_{52}\right)$; Dresser, B. Eur.

viii. p. 58r, pl. 623 ( $\left.8_{77}\right)$; B. O. U. List. Brit. B. p. $207\left(\mathrm{I} 88_{3}\right)$; Saunders, ed. Yarrell's Brit. B. iv. p. 8 I

( 1884 ) ; id. Man. Brit. B. p. 687 (I889); Lilford, Col.

Fig. Brit. B. part xxiii. ( 1893 ).

Alca grylle, Seebohm, Hist. Brit. B. iii. p. $3^{8} 3$ ( $\left.188_{5}\right)$.

(Plate CVIII.)

Adult Male in Summer Plumage.-Entirely black above and below, including the quills and tail; lesser wing-coverts black 
like the back; median and greater coverts pure white, with a line of black along the base of the latter, this black band mostly concealed by the median series; all the under wingcoverts and axillaries white, excepting those round the bend of the wing, which are blackish; bill black; feet dark crimson; claws black. Total length, II.5 inches; culmen, $\mathbf{I}_{4} 4$; wing, 6.1 ; tail, I.8; tarsus, I.25.

Adult Female.-Similar to the male. Total length, $12{ }^{\circ} \mathrm{O}$ inches; culmen, $\mathrm{I} \cdot 3$; wing, $6 \cdot 3$; tail, $\mathrm{I} \cdot 75$; tarsus, $\mathrm{I}^{\cdot} \cdot 2$.

Adult in Winter Plumage.-Differs from the summer plumage in being white below, the flank-feathers showing black bars, which impart a mottled appearance to the sides of the body. The white plumage is assumed by a direct moult, so that in autumn the birds are often found curiously speckled, when the new white plumes are appearing in the midst of the remains of the black summer dress. The crown, neck, and upper tailcoverts are margined with hoary white; bill black; feet carmine.

Young Birds.-Easily recognisable by the black ends to the wing-coverts, and after the moult this character at once distinguishes the young from the fully adult birds, the pure white patch on the wing being a sure sign of an old bird. The young have the under surface of the body mottled with dusky blackish edgings to the feathers, these being more distinct on the flanks. The scapulars are also edged and tipped with white, giving a mottled appearance, which, however, varies very much in extent. The feet are vermilion red in the young birds. It has been surmised that the old birds, having once attained their black plumage, never lose it in winter, but this is a mistake. At the same time, it is evident, as I have also been assured by Mr. J. G. Millais, that the white breast lasts but for a few weeks, and a specimen killed by Mr. Nikolai Hanson near Christiansund on the $\mathrm{I} 9$ th of December has lost most of the whitish edgings to the feathers of the upper surface, and is evidently beginning to assume the full black plumage on the back.

Young in First Plumage.-Dingy black above, and not showing any hoary margins till after the first moult.

Nesting.-Covered with silky down of a sooty brown colour. 
Range in Great Britain.-The Black Guillemot breeds on the west coast of Scotland, as well as on the Hebrides and the Orkneys and Shetland Islands. A few pairs also nest on the Isle of Man. In Ireland, according to Mr. Ussher, it also breeds, "usually in small numbers in crevices of the cliffs of Donegal, Antrim, Dublin, Wicklow, Waterford, Cork, Kerry, Clare, Galway, and Mayo. A great many seem to breed on the outer side of Owey Island and Arranmore, Co. Donegal."

Range Outside the British Islands.-The present species is found breeding in the Northern Atlantic, in the Baltic and White Seas, on the coasts of Denmark and Scandinavia, as well as in the Faeroes, and in Southern Greenland. In winter it has been found as far south as Massachusetts, and it also visits the shores of the German Ocean and Northern France at that season of the year.

Further to the north, the place of the Black Guillemot is taken by an allied species, $C$. mandti, which is distinguished by the complete, or almost complete, absence of the black base to the greater wing-coverts, and in winter the latter bird is easily recognisable by its white rump and by the greater amount of white on the scapulars.

Habits.-These are well described by Seebohm :-

"In its habits the Black Guillemot very closely resembles the Common Guillemot and the Razor-bill. It is a bird of the sea, and only visits the rocks to rear its young. At all times of the year it is sociable, though perhaps never seen in such vast assemblies as the Common Guillemot. It is more usual to see half-a-dozen birds swimming and feeding together, sometimes close in shore, in the sheltered sea-lochs, paddling amongst the floating seaweeds, and ever and anon diving to catch a tiny fish or search for crustaceans. The Black Guillemot loves a rockbound coast; the surf is never too rough or the sea too stormy for this bird. It is by no means shy, unless repeatedly fired at, and allows a boat to approach quite close ere it dives, with the rapidity of thought, and again appears far out of danger. It swims most buoyantly, sitting high and lightly on the water, with head and neck extended. . No bird rivals it in diving, and its progress under water, aided by its wings as well as its feet, is quite as rapid as its passage through the air. It dives with 
such rapidity that it is very difficult to shoot at a long range, as it disappears at the flash of the gun, and is safe from danger ere the shot strikes the water where it was sitting a moment before. The flight of the Black Guillemot is rapid, straight, often considerably prolonged, performed by incessant beatings of the small narrow wings, and is seldom elevated more than a few feet above the surface of the water. As it approaches the rocks the bird gradually rises in a straight line from the sea and alights abruptly on the cliffs. Flocks of a dozen or more of the birds may frequently be seen flying rapidly in strings over the surface of the water, bound to or from a favourite fishing-ground. It walks but little on the land, though capable of doing so rather quickly, and it sits on the rocks like a Guillemot, resting on the tarsus as well as on the foot. The Black Guillemot does not appear to wander about so much as the Common Guillemot, and obtains most of its food near home. It is abroad late in the evening, for it may often be seen fishing in the dusk, and it is one of the earliest birds astir at dawn. Many birds pass the whole night on the sea, sleeping safely on the water, but usually they retire to the neighbouring rocks at dusk. In winter it almost exclusively lives on the sea, only occasionally visiting the land.

"The food of the Black Guillemot is principally composed of the fry of fish, especially of the coal-fish and herring, which literally swarm in many Scotch waters. In search of these fry it explores the water quite close to the rocks, often seeming only very narrowly to escape being dashed on them by the force of the waves. It also feeds largely on crustaceans and very small shellfish. The note of the Black Guillemot is described by Capt. Feilden as a plaintive whine; and Saxby describes that of the young birds as shrill but rather plaintive."

Nest.-None, the eggs being generally placed in the crevice of a rock, sometimes at the base of a cliff, at other times at a height of several hundred feet, while occasionally the bird is found breeding far inland.

Eggs.-Two in number. Ground-colour white or greenishwhite, with black spots generally distributed over the egg, and with very distinct underlying spots of purplish-grey, which sometimes form large blotches. The black markings are often 



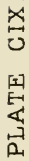

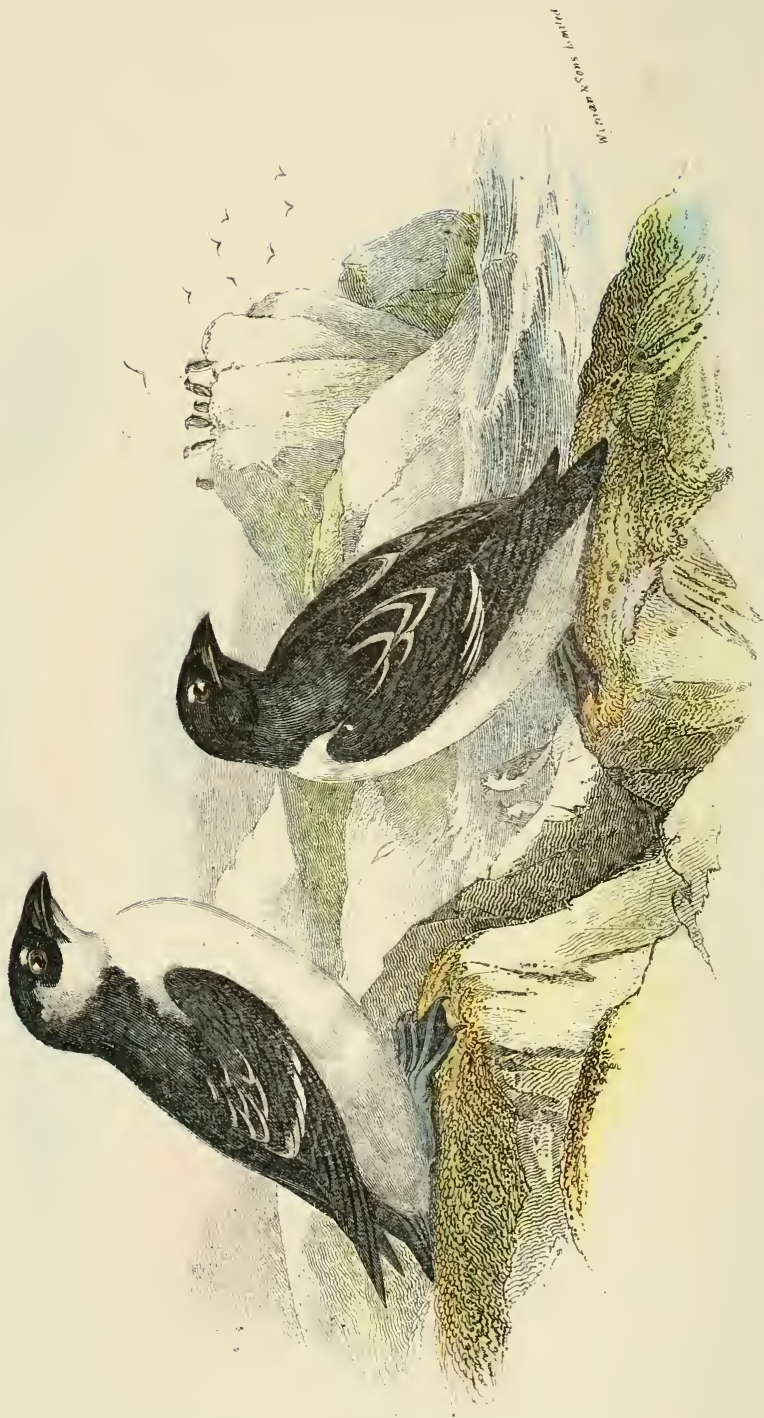

舀 
confluent, and form a very big patch. Varieties also occur in which the ground-colour is of a faint lilac, with blotches of brown and grey of about equal size occurring all over the egg. Axis, $2 \cdot 1-2 \cdot 55$ inches ; diam., $I^{\cdot} 55^{-1} 7$.

THE ROTCHES, OR LITTLE AUKS. GENUS ALLE. Alle, Link. Beschr. Nat. Samml. Univ. Rostock, i. p. I7 (I806). Type $A$. alle (Linn.).

The Little Auks are of diminutive size, with a small swollen bill without any sulcations or ridges; the culmen is rounded, the length from the gape to the tip of the bill being less than the middle toe and claw, and there is no notch near the end of the upper mandible. The nostrils are ovate and exposed, the frontal plumes not impinging upon the nasal apertures. The line of the tomia, or cutting edge of the bill, is decurved.

I. THE LitTLE AUK. ALLE ALLE.

Alca alle, Linn. Syst. Nat. i. p. 2 I I (1766); Seebohm, Hist. Brit. B. iii. p. 380 (1885).

Mergulus alle, Macgill. Brit. B. v. p. 340 (1852); Dresser, B. Eur. viii. p. 59I, pl. 624 (1877) ; B. O. U. List Brit. B. p. 208 ( 1883 ) ; Saunders, ed. Yarrell's Brit. B. iv. p. 85 (I884) ; id. Man. Brit. B. p. 689 (I889) ; Lilford, Col. Fig. Brit. B. part xxiii. (1893).

\section{(Plate CIX.)}

Adult.-General colour above black, varied on the scapulars with a few white streaks, these feathers being edged with white; wings and tail black, the secondaries tipped with white; sides of head and throat and fore-neck sooty black; remainder of under surface from the chest downwards pure white; the flanks streaked with black, the feathers being internally black, externally white; under wing-coverts and axillaries blackish; the greater coverts and the lower primarycoverts tipped with white; quills ashy below; bill leaden black; feet and toes livid brown, the webs darker; iris hazel. Total length, 7.5 inches; culmen, $0^{\circ} 65$; wing, 4.65 ; tail, $I^{\circ} 3$; tarsus, $0^{\circ} 7$. 
Adult in Winter Plumage--Differs from the summer plumage in wanting the black on the throat; the lores, base of chin, and feathers round the eye black; the sides of the neck white, with an indistinct collar round the hind-neck; the sides of the neck and the lower throat and fore-neck slightly mottled with blackish sub-terminal markings.

Considerable variation takes place in the amount of white on the under wing-coverts, which seems to be present in most winter-plumaged specimens, but is absent in some of them, and it is also absent in two summer-plumaged specimens examined by me. In the bird described, however, it is very strongly marked, and the white tips extend over all the marginal coverts on the outside of the wing underneath.

Range in Great Britain.-A winter visitor to our shores, sometimes occurring in great numbers, and often driven far inland by stress of weather. Specimens in summer plumage have also been observed, but up to the present date no authentic instance of the breeding of the species within British waters has been recorded. Mr. Howard Saunders states that he saw an old bird with its young one near the island of Pabbay in the Outer Hebrides on the $5^{\text {th }}$ of August, I886 ; and an adult was actually obtained off Monach Island, in the same group, on the $24^{\text {th }}$ of June, I 893 . In the winter of I894-95 a great visitation of the species took place, and a large number of specimens were captured in various parts of the British Islands. A paper on the occurrences in Scotland was published by Mr. W. Eagle Clarke in the "Annals of Scottish Natural History," for April, r895.

Range outside the British Islands. - The I.ittle Auk breeds in Greenland in great numbers up to nearly $79^{\circ} \mathrm{N}$. lat., as well as on Spitsbergen, Novaya Zemlya, Franz-Josef Land, and Northern Iceland. In winter it is found in the North Sea and Atlantic, and has been known to extend as far south as the Azores and the Canaries, while on the American side it has been procured off the New England coast in winter.

Habits.-Mr. Howard Saunders remarks:-"On the approach of a vessel, this bird has a peculiar habit of splashing along the surface of the water-as if unable to fly--and then diving through the crest of an advancing wave. It swims 
rather deep, and very much 'by the stern,' as Mr. Abel Chapman has remarked; so that, apart from its diminutive size, it is easily recognisable. The Little Auk bears a remarkable resemblance to the Diving Petrels (Pelecanoides) of the Antarctic seas. " Both the birds," says the Rev. A. E. Eaton, "have a hurried flight; both of them, while flying, dive into the sea without any interruption in the action of their wings, and also emerge from beneath the surface flying, and they both of them swim with the tail rather deep in the water. But this resemblance does not extend to other particulars of their habits. The Rotche, when breeding, usually flies and fishes in small flocks of six or a dozen birds, and breeds in communities of considerable size, which are excessively noisy. Diving Petrels, on the other hand, are more domestic in their mode of living, fishing and flying, for the most part, in pairs or alone, and breeding sporadically."

Seebohm gives the following account of the habits of the species :-

"The Little Auk is almost exclusively an oceanic bird, and seldom approaches land except during the breeding season. It sleeps on the water with its head tucked under its wing, and in rough weather is often tossed from wave to wave without apparent injury. It is a very expert diver, and can fly with great rapidity, though it is obliged to move its short wings almost as quickly as a Humming-bird or a Hawk-moth. Its flight is without undulations, but it turns with great ease. It is one of the most gregarious of birds, and Arctic travellers have sometimes estimated the flocks to consist of millions. It does not appear to be very active on the land. It is said to sit on the tarsus as well as on the foot, but only rests on its feet when running. At all seasons of the year flocks of these little birds may be observed in the open Polar seas, diving in search of food or perching on the masses of ice. Unlike the Guillemot and Razor-bill it is a very noisy bird, and its notes are constantly uttered both when on the wing and when at rest, either on the rocks or on the ice floes, or even when sitting on its egg. Its specific name of alle is said to bear a slight resemblance to its note.

"Soon after the young are hatched their parents convey them to the sea, where they may often be seen long before they 
are able to fly. The breeding places are now deserted, and the little birds wander about the open ocean in search of their favourite food. In rough weather they are said to come nearer to the shore, and to frequent the land-locked bays and quiet fjords. They seem but poorly adapted to withstand any violent storm, and are soon driven exhausted ashore, often for some considerable distance inland. The Little Auk only rears one nestling in the year, but it probably lays again if its first egg is taken.

"The food of the Little Auk is principally composed of minute crustaceans, and probably small fish and marine insects. When engaged in rearing its young, it appears to store a great quantity of these small crustaceans in its mouth, visibly puffing out its cheeks as Swallows and other insect-feeding birds do, so that it may convey a large amount of food to its distant nestling at once."

Nest.-None, the eggs being either placed in a cliff high above the water, or in a crevice or under stones, often at some distances beneath the latter.

Eggs.-One. Uniform greenish-white. Axis, $\mathrm{I}^{\circ} 9-2^{\cdot} \mathrm{I}$ inches ; diam., $I \cdot 3-1 \cdot 35$.

THE PUFFINS. GENUS FRATERCULA.

Fratercula, Briss. Orn. vi. p. S I ( 1760$)$.

Type, $F$. arctica (Linn.).

The Puffins are easily distinguished from the rest of the Auks by their peculiar bill, which has deep grooves or sulcations, while in summer there are some wattles on the face. The nostrils are exposed, and are not approached by any of the close-set plumes of the face. In some of the Pacific species of Puffins (Lunda), there is a remarkable tuft of hairy straw-coloured feathers springing from behind the eye.

I. THE PUFFIN. FRATERCULA ARCTICA.

Alca arctica, Linn. Syst. Nat. i. p. 2 I I (I 766 ).

Mormon arcticus, Macgill. Brit. B. v. p. $365(1852)$.

Fratercula arctica, Dresser, B. Eur. viii. p. 599, pl. 625 (1877,

B. O. U. List Brit. B. p. 208 ( 1383$)$; Saunders, ed. 



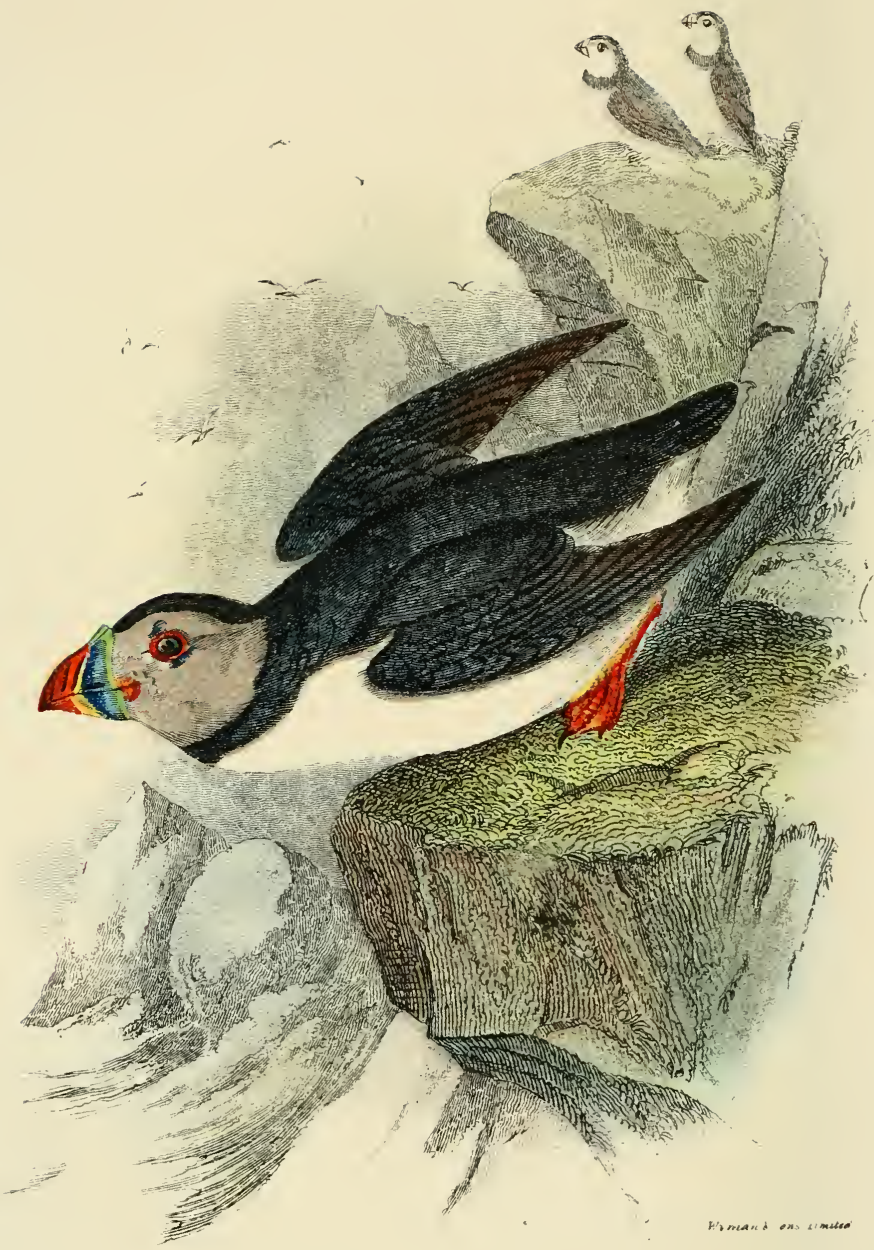


Yarrell's Brit. B. iv. p. 69 I (1884); Seebohm, Hist. Brit. B. iii. p. 364 (1885); Saunders, Man. Brit. B. p. 69I (I889); Lilford, Col. Fig. Brit. B. part x. (г889).

(Plate CX.)

Adult Male in Summer Plumage.-General colour above black, including the wings and tail; the quills ashy-brown on their inner webs; head black like the back, with a narrow, faintly defined line of grey round the nape; the lores, eye-brows, and sides of crown, sides of face, cheeks, chin, and upper throat pale grey, a little darker at the base of the lower mandible and on the chin, forming a kind of dusky moustachial band; under surface of body, from the lower throat downward, pure white, separated from the grey of the face and chin by a broad black band across the middle of the throat, joining the sides of the neck on either side; under surface of the quills and under wing-coverts light ashy; axillaries and adjoining feathers on the sides of the body blackish ; thighs ashy-brown; "the bill has the terminal half of both mandibles carmine, followed by a narrow band of pale yellow, and the basal half slate-grey, followed by another pale yellow band at the base of the upper mandible, and a red one at the base of the lower; legs and feet orange; iris hazel; orbits carmine; bare horny skin above and below the eye slate-grey; loose skin at the gape yellow" (Seebohm). Total length, I 3.0 inches; culmen, I.8; wing, 6.3 ; tail, $\mathbf{I} \cdot 75$; tarsus, 0.95 .

Adult Female.-Similar to the male; but with a somewhat smaller bill. Total length, 12 inches; culmen, $1{ }^{\circ} 5$; wing, $6{ }^{\circ}$; tail, $\mathrm{I} \cdot 65$; tarsus, 0.9 .

Winter Plumage. - The black shade on the face is present in all the specimens killed in winter, so far as the British Museum collection is concerned, even when the bill is developed to its full size. Whether this is a sign of immaturity or whether it is also a mark of winter plumage in the adults, I am unable to say for certain. By the shedding of the ornamental portions of the bill, the latter is very much smaller in winter than in summer.

1) stling.-Covered with sooty-black down, with a large patch of creamy-white on the belly. 
Young.-Like the adults in colour, but casily distinguished by its small bill, and the greater amount of dusky black on the face, which extends over the lores and round the eye. The culmen is nearly straight, and the maxilla without corrugations ; the genys, on the other hand, is abruptly curved upwards towards the tip.

Range in Great Britain.-Large colonies of Puffins are found breeding in various localities in the United Kingdom, particularly on the west coast, from the Scilly Islands northwards. Some nest also on the south-west coast, of England, from the Isle of Wight to Cornwall. On the east coast of England, Flamborough and the Farne Islands are well-known breeding haunts of the Puffin. In Ireland, says Mr. Ussher, "the species has some vast colonies on the precipitous coasts and islands, and it breeds in the following counties:-Donegal, Antrim, Dublin, Wexford, Cork, Kerry, Clare, Galwav, and Mayo. Some of its largest settlements are on the Saltees, in Wexford, the isles of Kerry, the north coast of Mayo, and Hoon Head, in Donegal."

Range outside the British Islands.--From the north of Scandinavia, the Faeroes, and Iceland, the Puffin breeds, down to the above-mentioned localities in Great Britain, the north coast of France, and the west of Portugal, where Mr. Saunders says that he noticed the species in large numbers off the Berlengas Islands, in June, 1868. In winter the Puffin visits the Mediterranean Sea, and in North America it breeds as far south as Newfoundland, and reaches the New England coast in winter.

A large form, with a somewhat larger bill and a slightly greyer head, Fratercula glacialis, is found in Spitsberyen, Novaya Zemlya, and the coast of Greenland. Although the grey head is more constantly seen in Spitsbergen examples, it is also sometimes to be observed in specimens of the Common Puffin, and I think that this appearance may be due to bleaching.

Habits.-The Puffins feed their young almost entirely on small fish, and frequently go long distances to obtain a supply of food. Mr. Drane, of Cardiff, tells me that he once saw a 
young Puffin with its crop distended, and he killed the bird to find out what the food was. The crop contained forty-one small fish, which have been identified as the young of the Lancelet (Ammodytes lanceolatus). Mr. Drane says that he has seen Puffins in thousands feeding almost entirely on this fish, which seemed to constitute their chief food. Marine insects and crustaceans are also eaten.

From its curious bill and large head the Puffin is often called the "Sea Parrot." It is a bird of rapid flight, and a most expert swimmer and diver, but is very awkward on land.

For a good account of its habits, I have resorted to the writings of the late Dr. A. E. Brehm on the bird-rocks of Lapland:--

"The farther we went, the more magnificent became the spectacle. The whole hill was alive. Hundreds of thousands of ey es looked down upon us intruders. From every hole and corner, from every peak and ledge, out of every cleft, burrow, or opening, they hurried forth, right, left, above, beneath; the air, like the ground, teemed with birds. From the sides and from the summit of the berg thousands threw themselves like a continuous cataract into the sea in a throng so dense that they seemed to the eye to form an almost solid mass. Thousands came, thousands went, thousands fluttered in a wondrous mazy dance; hundreds of thousands flew, hundreds of thousands swam and clived, and yet other hundreds of thousands awaited the footsteps which should rouse them also. 'There was such a swarming, whirring, rustling, dancing, flying, and creeping all about us that we almost lost our senses ; the eye refused duty, and his wonted skill failed even the marksman who attempted to gain a prize at random among the thousands. Bewildered, hardly conscious, we pushed on our way until at length we reached the summit. Our expectation here at last to regain quietness, composure, and power of observation, was not at once realised. Even here there was the same swarming and whirring as further down the slope, and the cloud of birds around us was so thick that we only saw the sea dimly and indefinitely as in twilight. But a pair of Jerfalcons, who had their eyrie in a neighbouring precipice, and had seen the 
unusual bustle, suddenly changed the wonderful scene. The Razor-bills, Guillemots, and Puffins were not afraid of us ; but on the appearance of their well-known and irresistible enemies the whole cloud threw themselves with one accord, as at the command of a magician, into the sea, and the outlook was clear and free. Innumerable black points, the heads of the birds swimming in the sea, stood out distinctly from the water, and broke up the blue-green colouring of the waves. Their number was so great that from the top of the berg, which was over three hundred feet high, we could not see where the swarm ended, could not discover where the sea was clear from birds.

"The millions of which I had been told were really there. This picture of apparent quiet only lasted for a few moments. The birds soon began to fly upwards again, and as before hundreds of thousands rose simultaneously from the water to ascend the hill, as before a cloud formed round it, and our senses were again bewildered. Unable to see, and deafened by the indescribable noise about me, I threw myself on the ground, and the birds streamed by on all sides. New ones crept constantly out of their holes, while those we had previously startled now crept back again; they settled all about me, looking with comical amazement at the strange form among them, and approaching with mincing gait so close to me that I attempted to seize them. The beauty and charm of life shewed themselves in every movement of these remarkable birds. With astonishment I saw that even the best pictures of them are stiff and cold, for I remarked in their quaint forms a mobility and liveliness with which I had not credited them. They did not remain still a single instant, their heads and necks at least were moved incessantly to all sides, and their contours often showed most graceful lines. It seemed as though the inoffensiveness with which I had given myself up to observing them had been rewarded by unlimited confidence on their part. The thousands just about me were like domestic birds ; the millions paid me no more attention than if I had been one of themselves."

Nest.-None, the egg being placed in a fissure of the cliff or in a burrow. 
Eggs.-White, with a few spots of pale brown. The spots are generally obscure, and frequently the underlying grey spots are most in evidence. Occasionally, when the spots are more distinct, they form zones round the large end of the egg. In some the underlying grey spots are very distinct and are scattered all over the surface. The eggs soon become stained to a buff, or reddish-buff, or chestnut colour. Axis, 2.25-2.55 inches; diam., I'65-I'75.

\section{THE PETRELS. ORDER PROCELLARIIFORMES.}

The Petrels are distinguished from the Gulls and other seabirds by their tubular nostrils, whence they are often called Tubinares. The palate is schizognathous, the nostrils holorhinal. The anterior toes are fully webbed, and the hind-toe or hallux is very small, being often entirely wanting. The spinal feather-tract is well-defined on the neck, and the oilgland is tufted.

The young are hatched covered with down, and are fed by the old birds for some time in the nest. The eggs are entirely white, or have a zone of reddish dots round the larger end. They are generally placed in holes burrowed in the ground, often on the lofty summits of oceanic islands, while some species make a nest in the open. The Petrels range in size from the dimensions of a large Swallow to those of an Albatross, which has the widest stretch of wing of any existing bird. (Cf. Salvin, Cat. B. Brit. Mus. xxv. p. 34 I.)

Mr. Osbert Salvin has recently published a classification and

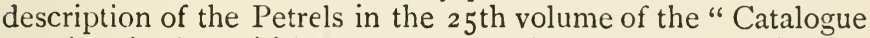
of Birds in the British Museum," and he arranges them in four families, viz. :-I. Procellariide, or Storm-Petrels ; II. Puffinide, or Shearwaters and Fulmars; IIl. Pelecanoidide, or Living-Petrels; and IV. Diomedeide, or Albatrosses.

\section{THE STORM-PETRELS. FAMILY \\ PROCELLARIIDA.}

In this family, which contains the smallest of the Petrels, the no:trils are united exterrally above the culmen; the 
margin of the sternum is even ; pterygoid processes are absent ; the manubrium of the forcula is long; the coracoids are long, comparatively narrow across the base, and slightly divergent; The second primary is the longest. (Cf. Salvin, tom. cit. p. 342.)

\section{THE TRUE STORM-PETRELS. SUB-FAMILY PROCELLARIINA.}

The plumage of the Petrels is somewhat close-set and a peculiar musky odour is perceptible in all of the species, both large and small. The same smell attaches to the eggs, and seems never to evaporate entirely.

An interesting note on these birds has recently been published by Mr. R. Drane, of Cardiff :- "I am disposed to the belief that the birds of this family do not enter the water as they are assumed, and very naturally assumed, to do ; for I have now had three species in confinement, Leach's Storm Petrel, the Greater Shearwater, and the Manx Shearwater, and, in each case, I find that when these birds really enter the water, they make strenuous efforts to get out of it, and that, succeeding, they are so drenched as to be incapable of flight. This statement has been met by the suggestion that the unnatural conditions of confinement effect a change in the quality of the plumage, which might account for this saturation. Remembering this, I immersed a Shearwater in the sea within an hour or so of its capture, and the result was the same. Be the explanation what it may, this fact remains, as the result of repeated observation, that I cannot drench a Duck or a Gull by immersion, and that I cannot immerse a Petrel without drenching it. I have failed to tame any of these birds or to induce them to take food spontaneously."

The members of this sub-family have the following characters, which are set forth by Mr. Salvin in the work above referred to:- " Leg-bones shorter than the wing-bones; tarsus never twice as long as the femur; basal phalanx of the middle toe shorter than the next two joints; the keel of the sternum entirely ossified ; tarsus covered in front with hexagonal scutes; claws sharp and compressed; outer toe shorter than the middle toe ; secondaries at least thirteen in number."

Three genera are represented in the sub-family, of which 



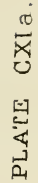

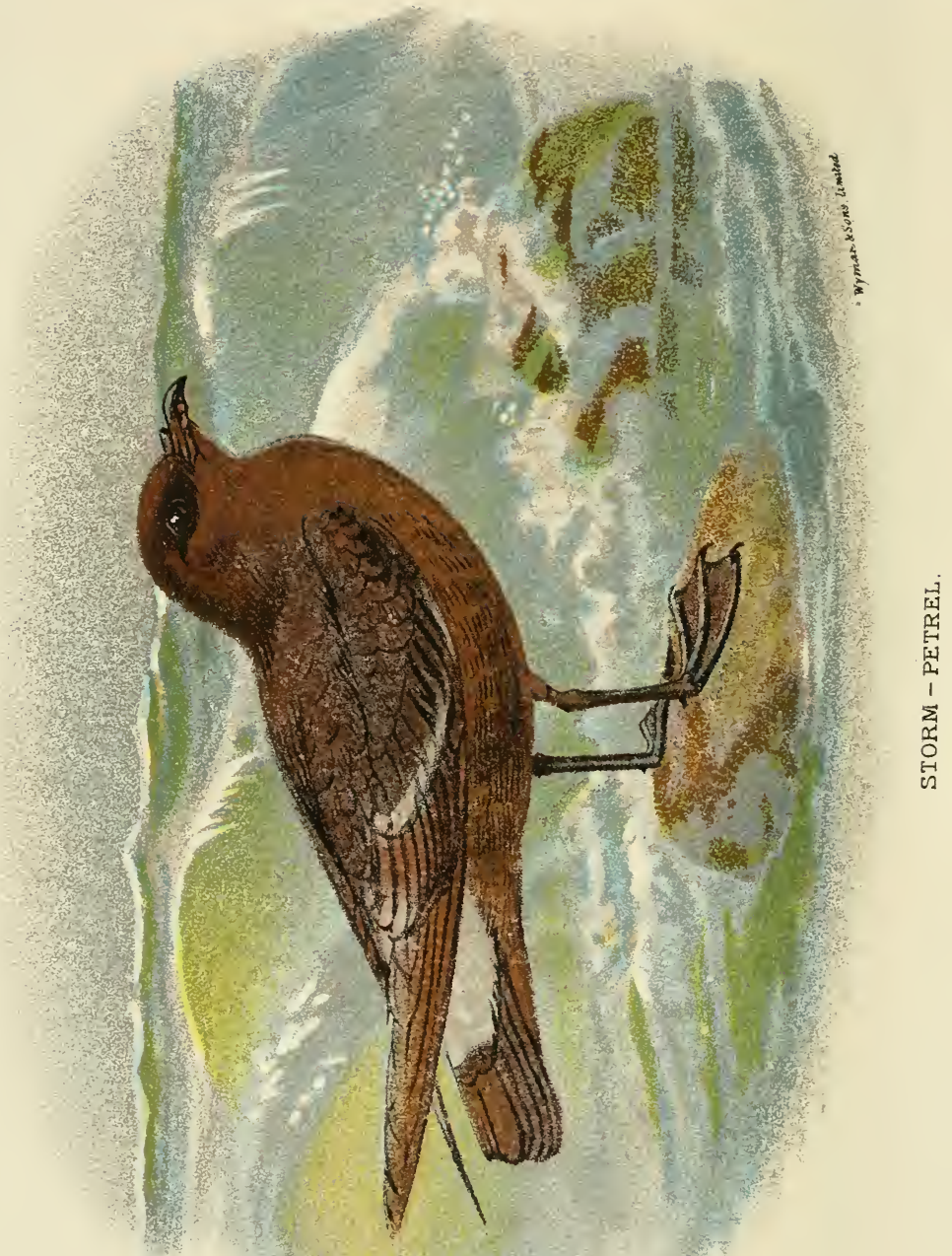


two are British, viz., Procellaria and Oceanodroma. The third, Halocyptena, is only found off the west coast of North America, from California to Panama, and contains but a single species, H. microsoma.

THE STORM-PETRELS. GENUS PROCELLARIA.

$$
\begin{gathered}
\text { Procellaria, Linn. Syst. Nat. i. p. } 2 \text { I } 2 \text { (1 } 766) . \\
\text { Type P. pelagica (Linn.). }
\end{gathered}
$$

In this genus the tarsus is longer than the middle toe and claw, and the tail is rounded or nearly even, never forkcd. Only two species of Procellaria are known, $P$. tethys being confined to the seas of the western coast of South America.

1. THE STORM-PETREL. PROCELLARIA PELAGICA.

Procellaria peiagica, Linn. Syst. Nat. i. p. 2 I 2 ( 1766$)$; B. O. U. List Brit. B. p. 196 ( 1883 ) ; Saunciers, ed. Yarrell's Brit. B. iv. p. 42 (1884); Seebohm, Hist. Brit. B. iii. p. 438 (1885) ; Saunders, Man. Brit. B. p. 727 (1889) ; Salvin, Cat. B. Brit. Mus. xxv. p. 343 ( 1896 ).

Thalassidroma pelagica, Macgill. Brit. B. v. p. $460(1852)$; Dresser, B. Eur. viii. p. 491 (1874).

$$
\text { (Plate CXIa.) }
$$

Adult Male.-Sooty-black above and below, with more or less of a greyish shade; rump and sides of lower back white; upper tail-coverts white, tipped with black; wing-coverts sooty black, the greater series narrowly but plainly edged with white; quills and tail black; under surface of body sooty brown, shaded with grey over the head and face, as well as on the throat and chest; under tail-coverts sooty black, the lateral ones white with black tips; under wing-coverts sooty black, the median series broadly edged with white; bill, legs, and feet black; iris hazel. Total length, 6 inches; culmen, $0^{\circ} 5$; wing, 4.75 ; tail, 2.1 ; tarsus, 0.8 .

Adult Female.-Similar to the male. Total length, 6 inches; wing, $4 \cdot 8$

Nestling.--Enveloped in sooty down, the feathers as they are developed being exactly like those of the adults. 
Range in Great Britain.-Found on all the seas round the British coasts, and sometimes occurring in some numbers, especially in the late autumn. In May the Storm Petrel arrives to breed, and it betakes itself to the islands off the coasts of Scotland and Ireland, and also does the same in a few localities in the west of England, such as the coasts of Wales and the Scilly Islands. On the eastern coast no breeding places are known. Mr. Ussher says that in Ireland the StormPetrel "breeds on islands off the coasts of Donegal, Antrim, Kerry, Galway, and Mayo. Very large colonies exist on some of the islands off Kerry."

Range outside the British Islands. - The Storm-Petrel is an inhabitant of the North Atlantic Ocean on both sides, visiting the Mediterranean, and extending its range South to West Africa.

Habits.-Mr. W. H. Turle gives an interesting account of a visit to the Blasquet Islands, and tells us how, when he arrived in the dark, the inhabitants of the cabin lighted their only candle on receiving him, this candle being a " rush drawn through the oily body of a Stormy Petrel." Mr. Turle found the species breeding among the rocks, and in what had evidently been rabbit-holes. It is said to form an article of food on the Blasquets, and Seebohm ate some of the young birds during his visit to these islands in 1856 . He found them delicious eating when cooked on toast like Snipe, and he pronounces them to have been "very rich, but not at all fishy."

Seebohm gives a good description of the Storm Petrel, as he observed it on the Blasquets:- "Our foreground for half a mile or so all round was a mass of rocks, here and there rising into a grassy knoll generally crowned with rocks. No tree of any description was visible; we did not find so much as a shrub on the whole island, unless half-a-dozen scattered bramble bushes may be allowed to club together and unitedly attain to the dignity of shrub. The only houses on the island were a couple of cabins, half above and half under ground, without window or chimney, and with no mortar in the walls.

"Whichever way we turned we could see nothing but rocks and piles of rocks, with grassy slopes between, where rabbits abounded and a few sheep grazed. The coast was grand 
beyond description, most of the island being at an elevation of three or four hundred feet above the level of the waves. Rocky promontories stretched far into the sea; huge masses of rock protruded from the ocean and rose one or two hundred feet high. Here the waves dashed against perpendicular cliffs, and there they foamed and fretted against craggy piles of rocks; and in many places the sea had hollowed out caves underneath the cliffs or worn chasms in the coast, which extended up into the mainland like Norwegian fjords. Such was the home of the Stormy Petrel; but at first we did not suspect the existence of these birds on the island. The natives (with whom we were obliged to converse through our "Buttons," a young Celt who accompanied us to do the dirty work) continually assured us that we should soon be able to add the dainty dish of fried "Blasquet Chickens" to our modest menu ; but it was not until the I Ith of September that they were able to produce these wonderful birds, which proved to be young Stormy Petrels, as large almost as their parents, with half feathers, half down. Cooked on toast like Snipe, we found them delicious eating, very rich, but not at all fishy. As soon as we discovered that we were encamped in the midst of a colony of these interesting birds we commenced a diligent search, and soon found plenty of young, besides catching a few old birds which were still sitting on unhatched eggs. The nests, which seldom consisted of more than a dozen blades of dead grass, were placed in holes in the rocks or the rough walls put up to protect the little potato patches from the sheep. We could often detect their presence in the evening by the faint cry of the young bird clamouring for food, and in places where the loose stones had been piled into heaps we found that the removal of half of them often disclosed several nests to view.

"On the I 7 th of September I took the boat and crossed over to the adjoining island of Inishnubro, and found many young Petrels and a few still unhatched eggs. On this island the nests were principally on the steep grassy slopes in old rabbit burrows. We never by any chance saw a Stormy Petrel on the wing during the day; but when the nights became enlivened by moonlight we could see them flying about like bats, bringing food to their young. So far as we were able to judge, this was entirely oil. As soon as the young bird was 
taken in the hand it disgorged a few drops of amber-coloured oil, and in none did we find any solid matter in the stomach."

Nest.-None, or consisting only of a few blades of dead grass. The eggs are laid in Nay and some are even found as late as September, so that the Storm-Petrel probably raises two broods in the year.

Eggs.--One only.* Dull or dirty white, without gloss, thinly sprinkled with minute reddish-brown specks, and not unfrequently with an obscure zone of specks near the larger end. Axis, $1 \cdot 05-1 \cdot 2$ inch ; diam., $0.85^{-0} \cdot 95$.

THE FORK-TAILED PETRELS. GENUS OCEANODROMA.

Ocecinodroma, Reichenb. Av. Syst. Nat. p. iv. (1852).

$$
\text { Type, O. furcata (Gm.) }
$$

In this genus the tail is always distinctly forked, and, furthermore, the tarsus is shorter and never exceeds the length of the middle toe and claw.

Twelve species of Oceanodroma are known, and the genus is found all over the tropics.

I. THE FORK-TAILED STORM-PETREL. OCEANODROMA LEUCORRHOA.

Procellaria leucorrhoa, Vieill. N. Dict. d'Hist. Nat. xxv. p. 422 (1817) ; B. O. U. List Brit. B. p. 196 (1883).

Thalassidroma leachi, Macgill. Brit. B. v. p. 45I (1852).

Thalassidroma leucorrhoa, Dresser, B. Eur. viii. p. 497 pl. 6I3 ( 1874$)$.

Cymochorea lewiorrhoa, Saunders, ed. Yarrell's Brit. B. iv. p. 392 (1884).

Procellaria leachi, Seebohm, Hist. Brit. B. iii. p. $4+3$ (IS85).

Occanodroma leucorrhoa, Saunders, Man. Brit. B. p. 725 (1889);

Salvin, Cat. B. Brit. Mus. xxv. p $34^{8}(1896)$.

(Plate CXIb.)

Adult Male.-General colour above sooty-black, with more or less of an ashy or slaty-grey shade, especially on the head;

* Sir Ralph Payne-Gallwey speaks of the Petrel hatching her thrie white eggs! (Cf. Turle, Ibis., ISjI, p. II.) 

四

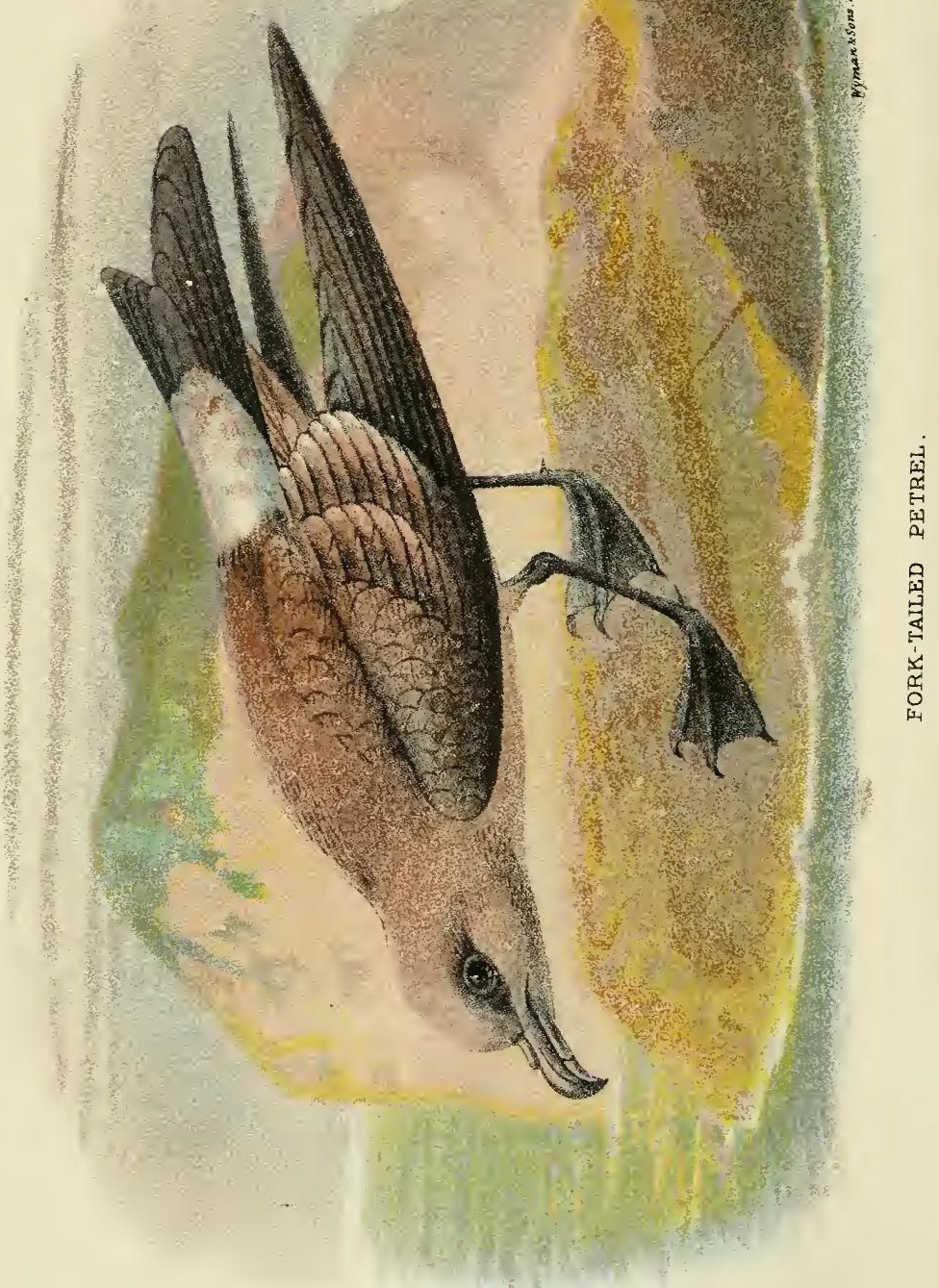


the scapulars with whity-brown tips ; lateral feathers of rump and upper tail-coverts white; lesser wing-coverts sooty-black like the back; median and greater coverts smoky-brown, the inner greater coverts edged with whity-brown; bastard wing, primary-coverts, and quills black, the inner secondaries edged with whity-brown at the ends; tail-feathers black, the centre ones rather browner; crown of head like the back, the forehead and lores rather clearer ashy, like the cheeks and throat ; feathers round eye, sides of face, and ear-coverts sooty-black, like the sides of the neck; throat rather lighter ashy than the remainder of the under surface of body, which is blackish-chocolate, somewhat lighter brown on the under tail-coverts, the sides of the vent being white; under wing-coverts and axillaries dark chocolate-brown; quills below black; bill, legs, feet, and claws, black ; iris dark hazel. Total length, 8 inches; culmen, 0.65 ; wing, 6.0 ; tail, $3{ }^{\circ}$; tarsus, $0^{\circ} 9$.

Adult Female.-Similar to the male. Total length, 7.5 inches: wing. $6 \cdot 15$.

Nestling.-Covered with sooty-brown down.

Range in Great Britain.- "Leach's Petrel," as this bird is often called, is found on all the coasts of Great Britain in winter, and is often driven inland by storms. It breeds on S. Kilda, and the outer Hebrides. In Ireland a few were found breeding, according to Mr. Ussher, "on the Blasquets, off the Kerry coast, in 1887 , 1888 , and 1889 , but not since."

Range outside the British Islands.-The Fork-tailed Petrel is found in the seas of the Atlantic and Pacific Oceans, inhabiting the temperate waters of the northern hemisphere, as Mr. Salvin puts it.

Habits.-Mr. C. Dixon contributed to Seebohm's "History of British Birds" the following notes from S. Kilda :- "The chief object of my visit to Doon was to obtain the eggs of the Fork-tailed Petrel, and I was successful beyond my highest expectations. We crossed the bay in a small boat belonging to the smack, dangerously overcrowded, as many St. Kildans as could scramble into her going with us to search for eggs and catch birds. Landing on this rock-bound islet was difficult work, 
owing to the strong swell. As we approached the shore one of the St. Kilda men leapt out of the boat with a rope and assisted the rest to land. After taking off our boots we climbed up the cliffs, and over the grassy slopes to the summit, where Donald told me we should find the birds we wanted. The place where the Petrels breed is on that portion of the island nearest to St. Kilda and at the summit. We had not been there long before Donald, who had been searching the numerous holes, drew forth a struggling Petrel from its nest, and I was delighted to find that it was the Fork-tailed species. Handing me the bird, he quickly drew forth the single white egg, and I then waited until he found another nest within a yard or so of the first. Inserting my arm to the full extremity I felt the little bird fluttering over its egg and drew it out. This nest also contained a single egg; and as I was catching the bird it uttered a few squeaking notes; excepting this, no other sound was heard during our stay. When held in the hand, it emits a small quantity of oil, precisely similar to that vomited by the Fulmar. Most of this oil comes from the mouth, but occasionally a little is squirted from the nostrils. Whilst I was packing the eggs Donald found another nest, which I took; and in less than half-an-hour I had taken eleven nests of this rare little bird. In two of the holes we found a bird, but no egg; they had probaby gone into the hole to pass the day; and in one hole there was an egg, but no bird. We never found more than one bird on the nest, and only a single egg is laid. Some nests are larger than others, but in one hole the egg was laid on the bare ground. The holes vary considerably in depth (from two to four or five feet), and are burrowed in a precisely similar manner to those of the Puffin. The holes are made in the soft peaty soil, and it is very easy to unearth the nest. Sometimes the hole has two entrances, and then it is necessary to stop one end up to prevent the bird from escaping. These holes, which are inhabited by Petrels, usually have a little dry grass at the entrance. Many nests are placed together, an underground colony in fact, and we found half a dozen nests within a radius of eight or nine yards. One of the birds which we caught, I let go again to watch its flight. It flew about for a few moments in a very erratic manner, as if dazed by the light, and then darted up and down, and flew 



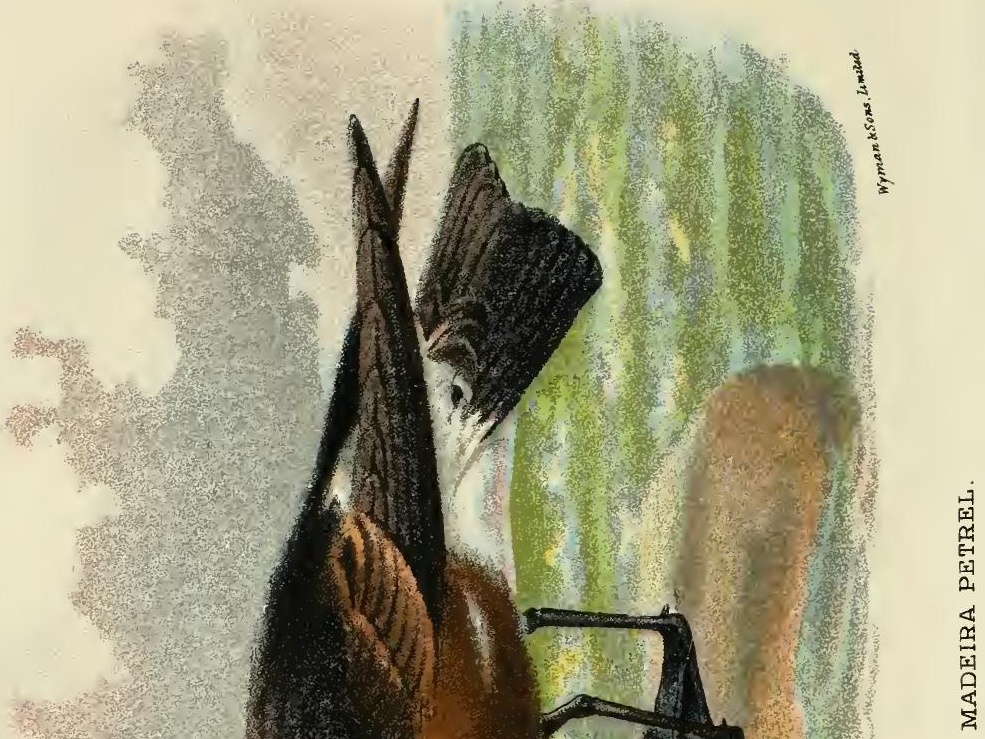


round and round with rapid beats of its long wings, very much like a Swallow or a Swift. We finally lost sight of it as it flew behind a large stack of rock and went out to sea. This bird, during its sojourn in St. Kilda at any rate, is almost exclusively nocturnal in its habits, and keeps close to its hole during the day. The egg is incubated by both parents, for I took male and female birds from the nests; but, as previously stated, I never met with two birds in the same hole. Most of the nine eggs I obtained were quite fresh, but three of them were slightly incubated. When I dissected the Petrels we caught, I found the stomachs to contain an oily substance mixed with little bits of sorrel."

Nest.-Of dry grass, with round stalks and dry blades, with a scrap or two of moss, and a few bits of lichen and roots (Dixon).

Eggs.-One. Dull white, with a zone of minute dots of very pale lilac round one end, in rare instances the spots being spread over the entire surface. Axis, $\mathrm{I}^{\cdot} 2-\mathrm{I} \cdot 35$ inches; diam., $0^{\circ} 95^{-1} \cdot{ }^{\circ}$.

THE MADEIRA STORM-PETREL. OCEANODROMA CRYPTOLEUCURA.

Cy'mochorea cryptoleucura, Ridgway, Proc. U.S. Nat. Mus. iv. p. 337 (1882).

Oceanodroma cryptoleucura, Baird, Brewer, and Ridgway, Water-Birds, N. Amer. ii. p. 406 (I884); Salvin, Cat. B. Brit. Mus. xxv. p. 350 (1896); Boyd Alexander, Bull. B. O. Club, v. p. xxxvii. (1896).

\section{(Plate CXIC.)}

Adult Male-General colour above sooty black, the greater wing-coverts browner externally, with light brown edges; quills black, the inner secondaries greyer on the outer webs, which are narrowly edged with hoary white; upper tail-coverts white, the long ones broadly tipped with black; head and neck sooty-black, with a slight shade of greyish; under surface of body socty-brown, including the central long under tailcoverts, the lateral ones being white, with broad black tips; tail-feathers black, white at the base, the white extending further on the outer ones; under wing-coverts black, the 
median series browner; bill and feet black. Total length, $7 \cdot 2$ inches ; culmen, 0.6 ; wing, 5.95 ; tail, 2.7 ; tarsus, 0.9 .

Adult Female.-Similar to the male. Total length, 7 inches; wing, 6.25 .

Nestling. -Covered with sooty-black down. The inner secondaries are narrowly but distinctly edged with white.

Characters. - The present species has a forked tail like the preceding one, but it is a blacker bird, and is recognised by the long upper tail-coverts having a broader sooty-black tip than in the Fork-tailed Petrel. It differs, moreover, in having the base of the outside tail-feathers white.

Range in Great Britain. A specimen of this Petrel was exhibited by Mr. Boyd Alexander at the meeting of the British Ornithologists' Club, on the 29th of April, 1896. This individual had been picked up dead on the beach at Littlestone, in Kent, on the $5^{\text {th }}$ of December, 1895 .

Range outside the British Islands. - This Petrel appears to be by no means uncommon in Madeira and the neighbouring Desertas and Salvage Islands. It is also known from S. Helena, and occurs in the Pacific Ocean on the Hawaian Islands and in the Galapagos. It was first described by Mr. Robert Ridgway, from the Hawaian Archipelago.

Habits.-Of this specie;, only described for the first time in I882, but little is known. It appears to be more plentiful in the Atlantic than in the Pacific Islands, where it was first discovered. Its habits are similar to those of the other small Petrels.

Nest.-In crevices of the rocks.

Eggs.-One only. White, with an ill-defined zone of dry blood-coloured spots at the larger end.

\section{THE FLAT-CLAWED STORM-PE'TREIS. SUB-FAMII,Y OCEANITINAE.}

In the preceding sub-family the claws are sharp and compressed; in the Oceanitince they are very flat. According to Mr. Osbert Salvin, the wing-bones are shorter than the 
leg-bones, and the tarsus is at least twice as long as the femur; the basal phalanx of the middle toe is as long as the ncxt two joints, or longer than them; the keel of the sternum has a large "fenestra"; the tarsi are usually covered in front with a single shield, or with transverse short scutes; the outer and middle toes are sub-equal in length, and the seconclaries are ten in number. (Cf. Salvin, Cat. Birds Brit. Mus. xxv. p. 343.)

\section{TIIE LONG-LEGGED STORM-PETRELS.}

\section{GENUS OCEANITES.}

Oceanites, Keys. und Blasius, Wirb. Eur. ii. pp. xciii. $131,23 \mathrm{~S}$ ( 1840$)$.

$$
\text { Type, O. oceanicus (Kuhl). }
$$

Two species of the genus Oceanites are known, viz., $O$. oceanicus, which inhabits the Atlantic, Indian, and Australian Oceans, and O. gracilis (Elliot), which is found along the western coast of South America.

In Oceanites the claws are not so much flattened as in Pelagodroma and the other genera of the sub-family, and the basal phalanx of the middle toe is normal or only slightly flattened, less so than the remaining joints and claws, the latter being sharp and spatulate. The scutellæ of the front of the tarsus are obsolete, a character distinguishing Oceanites from Garrodia, an allied genus with a single species, G. nereis, peculiar to the southern Oceans.

\section{WIISON'S PETREL. OCEANITES OCEANICUS.}

Procellaria cceanica, Kuhl, Beitr. p. I36 (1820).

Oceanites oceanicus, Dresser, B. Eur. viii. p. 505, pl. 61 4 (1878) ;

B. O. U. List Brit. B. p. I 97 (I883); Saunders, ed. Yarrell's Brit. B. iv. p. 48 (I884); id. Man. Brit. B. p. 729 (I 889); Salvin, Cat. B. Brit. Mus. xxv. p. $35^{8}$ (1896).

Oceanites wilsoni, Bp.; Seebohm, Hist. Brit. B. iii. ए). 449 (I885).

Adult Male.-Sooty black, the head and throat somewhat ashy, with the eqar-coverts slightly blacker ; wing-coverts sooty 
black, the greater series pale brown towards the tips; primarycoverts and quills black, browner on the inner webs, the secondaries also externally brownish; feathers of the lower rump black, tipped with white; upper tail-coverts pure white; tail black, the base of the feathers white, more extended on the outer ones; under surface of body sooty brown, darker on the sides, the under tail-coverts brown with white bases ; sides of vent conspicuously white, some of the feathers marked with sooty-brown; under wing-coverts sooty-brown, the inner ones slightly paler; bill black; feet black, with the webs yellow; iris black. Total length, $77^{\circ} \circ$ inches; culmen, 0.55 ; wing, $6 \cdot$ I ; tail, $2 \cdot 75$; tarsus, I. 4 .

Adult Female.-Similar to the male. Total length, $7 \cdot 2$ inches; wing, 6.8 .

Characters.-IVilson's Storm-Petrel may be at once distinguished from the other black-plumaged white-rumped species by the yellow webs to the toes.

Range in Great Britain.-Wilson's Petrel is apparently only an occasional visitor to our shores, occurring sometimes in considerable numbers off the south-western coasts of England. Thus Gould observed it off the Land's End in 1838 , and stray individuals have since been recorded from Wiltshire, the Isle of Wight, Sussex, Yorkshire, Cumberland, and Lancashire. Up to the present time it has not been noticed from Scotland, and only one doubtful occurrence off the Irish coasts has been recorded.

Range outside the British Islands.-The present species is known principally from the southern Oceans, occurring in Australian waters, and throughout the Antarctic seas, even to the ice barrier of the South Polar continent. Thence it is found northward in the Indian Ocean to the Mekran coast, also off the shores of West Africa, visiting the Mediterranean, and ranging to the British Islands in the Eastern Atlantic, and to Labrador on the western side of the last-named Ocean.

Habits.-The Rev. A. E. Eaton thus describes his experiences in Kerguelen Island, in the South Atlantic:-- "Having ascertained their call, we were able, by listening attentively, to detect the exact positions of several of these hidden birds. 
They were easily caught when the stones were rolled aside; but they were in couples, merely preparing for laying, and therefore we did not find any eggs. On our way back to Observatory Bay, after the 'Transit,' we called at the American Station, and were informed by Dr. Kidder that he had observed this Petrel on the shore near Molloy Point. The sea-shore in the neighbourhood of Observatory Bay is of a different character (for the most part) from that which is adjacent to the American Station, and, being less favourable than it, was seldom resorted to for nesting by the Petrels. The country in general about our bay afforded them unlimited accommodation. For, provided that they can find a slope of shattered rocks with suitable chinks and crevices, or dry spaces under stones or large boulders sheltered from draughts, whether they be near the Sound or on the sides and summits of high hills, they readily appropriate them.

"The egg is laid upon the bare ground within the recess selected by the birds, either in a chance depression formed by contiguous stones, or in a shallow circular hollow excavated in the earth by the parent. Having found numbers of their nesting-places, I will describe my method of searching for them. Whenever there was a calm night I used to walk with a darkened bull's-eye lantern towards some rocky hill-side, such as the Petrels would be likely to frequent. It was best to shut off the light and keep it concealed, using it only in dangerous places, where falls would be attended with injury and progress in the dark was hardly possible, lest the birds, seeing it, should be silenced. On arriving at the ground selected, it was probable that the Storm-Petrels would be heard in various directions, some on the wing, others on their nests, sounding their call at intervals of from two to five minutes. Those on nests could be distinguished from others flying by their cries proceeding from fixed positions. Having settled which of the birds should be searched after, a cautious advance had to be made in her direction, two or three steps at a time, when she was in full cry. As soon as she ceased an abrupt halt was imperative, and a pause of some minutes might ensue before she recommenced her cry and permitted another slight advance to be effected. In the course of this gradual approach the position of the bird might be ascertained 
approximately; but it had to be determined precisely, and to learn exactly where she was, the bird had to be stalked in the dark noiselessly. No gleam could be permitted to escape from the lantern. Loose stones and falls over rocks-to avoid them it was sometimes necessary to dispense with slippers, and feel one's way in stockings only, for should the Petrel be alarmed once with the noise or the light, she would probably remain silent a considerable time. Now and then it would happen that upon the boulder beneath which she was sitting being almost attained, the bird would cease calling. When this occurred, and many minutes elapsed without her cry being resumed, it was advisable to make a délour, and approach the rock from the opposite side, as her silence might be attributed to her seeing a person advancing towards her, and she would probably recommence her call so soon as he was out of sight. If she did not, a small pebble thrown amongst the rocks would usually elicit some sounds from her, as she would most likely conclude that the noise was being made by her mate returning to the nest. When the stone beneath which the bird was domiciled was gained at last, redoubled care had to be exercised. By stooping down and listening very attentively, her position could be accurately ascertained. Then the lantern was suddenly turned upon her before she had time to creep out of sight, and her egg could be secured with the hand, or with a spoon tied on to a stick.

"Sometimes I worked without a lantern, and marked the positions of the nest with piles of stones, so that they might be revisited by day. Several eggs were obtained in February from nests which had been thus marked early in the previous month. The first egg taken by us was found by a retriever on the 22 nd of January, on an island in Swain's Bay. Captain Fairfax sent me a nestling a day or two before we sailed for the Cape. Two of the eggs were laid in unusual situations. One of them was found by a man under a Pringlea plant; but this may have been an egg of Garrotia nereis. The other was deposited just above the tide-mark in a cavity of a rock rather open to the air and light. I had found the bird there one night, had taken her up into my hand, and had gently replaced her in the hollow, nearly a month before the egg was laid." 



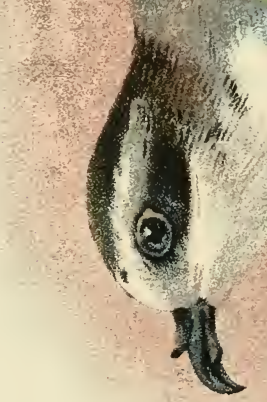

405 (

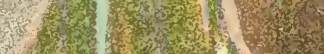


Nest.-None, the eggs being laid in crevices of rocks or under boulders, as described above by Mr. Eaton.

Eggs.-One. Dull-white, with a few lilac or reddish-brown dots, generally collected in a zone round the large end. Axis, $1 \cdot 3$ inch; diam., 0.95 .

THE GREY STORMI-PETRELS. GENUS PELAGODROMA.

Pelagodroma, Reichenb. Av. Syst. Nat p. iv. $(1852)$.

Type, $P$. marina (Lath.).

The genus Pelagodroma differs from Oceanites in having the claws flattened and wide. The colour is of a light grey, instead of black, and the breast is white. Only one species, $P$. marina, is known.

\section{THE WHITE-BELLIED STORM-PETREL. PELAGODROMA MARINA.}

Procellaria marina, Lath. Ind. Orn. ii. p. 826 (1790).

Pelagodroma marina, Salvin, Cat. B. Brit. Mus. xxv. p. 362 $(1896)$.

\section{(Plate CXId.)}

Adult.-General colour above brown, with a wash of ashygrey on the mantle; lower back, rump, and upper tail-coverts, clear grey with white bases; wing-coverts brown, the greaterseries ashy towards the enòs; bastard-wing and primarycoverts blackish-brown; quills blackish, ashy-brown on the inner web ; tail-feathers black, ashy at the base ; crown of head and nape dark slaty-grey, darkening towards the nape; forehead, lores, and eyebrow white, as also the sides of the face; the feathers round the eye and below the latter slaty-black, extending over the ear-coverts, cheeks and under surface of body pure white; sides of neck ashy-grey, extending on to the sides of the upper breast ; under tail-coverts ashy-grey; under wing-coverts and axillaries white, the edge of the wing mottled with brown; quills below dusky white towards the base of the inner webs; bill and feet black; webs of toes yellow; iris dark reddish-brown. Total length, 7.5 inches; culmen, 0.65 ; wing, 5.95 ; tail, 2.85 ; tarsus, 1.5 . 
Adult Female. - Similar to the male, but rather larger. Total length, 8 inches; wing, 5.8-6.6.

Young Birds.-Covered with a sooty-black down. The first feathers resemble those of the adults, but the grey feathers of the mantle are fringed with white, and the greater-coverts and secondaries are edged with white at the tips, the grey of the upper and under tail-coverts being barred with white. These markings are retained by the young bird, after it has become full grown and has lost the down.

Characters.-Apart from the generic characters recorded above, the present species can be easily recognised by its grey upper surface, blackish head, white under surface, and by the yellow webs to the toes.

Range in the British Islands.-This species has been known to occur on two occasions within our limits. One was picked up dead on Walney Island, Lancashire, in November, I890; and a second specimen has recently been recorded from the island of Colonsay in the West of Scotland, by Mr. W. Eagle Clarke. This specimen was obtained on the Ist of January, 1897 , after a succession of south-westerly gales.

Habits.-Mr. Ogilvie Grant, who met with this Petrel on the Salvage Islands, writes:- "This was certainly one of the most interesting species met with during our stay on Great Salvage. We first observed and recognised with pleasure these beautiful Petrels as we neared the Salvages, when numbers were seen flitting along close to the surface of the sea, with their long legs dangling beneath them and just touching the water. Now they would be lost sight of in the hollows between the huge Atlantic rollers, now reappear, closely following the undulating waters with their graceful easy flight. On the afternoon of our arrival at Great Salvage we found an egg of this bird in what we mistook for a rabbit-burrow, but it was unfortunately broken by one of the men. This, however, opened our eyes, and we subsequently found that large colonies of the White-breasted Petrel were breeding on the flat top of the island, in burrows dug out in the sandy ground, and partly concealed by the 
close-growing ice-plant. It was very unpleasant walking over these breeding-grounds, which occupied considerable areas, for the ground was honeycombed with burrows in every direction, and gave way at each step, one's boots rapidly becoming full of sand. By thrusting our arms into one hole after another, we soon procured a fine series of specimens, accompanied in most cases by an egg, fur we had evidently hit off the breeding season, and most of the birds, having laid their single egg, were beginning to sit. Both sexes take part in incubation, for out of twelve birds captured on the egg three were males. While thus engaged we found quite a number of dead birds and sucked eggs, evidently the work of the mice, as their droppings were to be seen all about the burrows, and the marks of their teeth upon the empty shells were unmistakable. The birds, some of which were quite freshly killed and almost untouched, were invariably done to death by being bitten at the nape of the neck, and in some cases part of the brain had been eaten. It seemed curious that these comparatively small mice should be able to kill a bird several times larger than themselves, and provided with a fairly strong hooked bill; but no doubt the Petrels get caught in the end of their burrow, and, being terrified, do not even try to defend themselves. We obtained no young of this species, and the most advanced eggs were but half incubated on the 27 th of April. We never heard the call of this bird; those flying over the sea during the daytime were always perfectly silent so far as we heard, though they constantly passed close to our tug, and there was no lack of them. When caught on their eggs they uttered a short, grunting note, much like that given vent to by the domestic Pigeon under similar circumstances. Our Lanzarote pilot informed us that numbers of these birds breed on the Little Piton, where there are neither rats nor mice to inter fere with them."

Nest.-None. The egg being laid in a sandy burrow.

Eggs.-One. White, with tiny reddish or purplish dots, sprinkled all over the surface, or forming a zone round the larger end. Axis, 145 inch; diam., I 05. 
THE FULMARS AND SHEARIVATERS. FAMII,Y PUFFINID我.

According to Mr. Osbert Salvin, this family of Petrels is distinguished by the following characters :- "Nostrils united, or nearly so, above the culmen ; margin of the sternum uneven; distinct pterygoid processes; manubrium of furcula very short; coracoids short, wide at the base and divergent ; first primary the longest, or not shorter than the second."

These birds are of larger size and stouter build than the Storm-Petrels, and are divided into two sub-families, the Fulmarina, or Fulmars, and the Puffinince, or Shearwaters.

\section{THE FULMARS. SUB-FAMILY FULMARIN必.}

The Fulmars are distinguished from the Shearwaters by the lamellæ which are more or less distinctly developed on the sides of the palate. Five genera are included by Mr. Salvin in this sub-family, the Giant Fulmar (Ossifraga) being as large as some of the smaller Albatroses. The Cape Pigeons (Daption) also belong to this group, as well as the Fulmars (Fulmarus), and the pretty little Blue Petrels of the Southern Ocean, Prion and Halobana.

THE TRUE FUlMaRs. GENUS FUlMarus.

Fulmarus, Stephens in Shaw's Gen. Zool. xiii. p. 233 (1826). Type, $F$. glacialis (Linn.).

In the Fulmars the feet and bill are very strong. The latter is stout, with the rami of the mandible strong and having a bare inter-ramal space. The nasal tube is short, but well developed, large and high at the base, equal to the width of the latericorn (cf. Salvin, Cat. B. Brit. Mus. xxv. p. 422). The tail-feathers are fourteen in number.

The three species of Fulmarus are found distributed orer the North Atlantic and North l'acific Occans. 



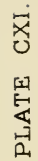

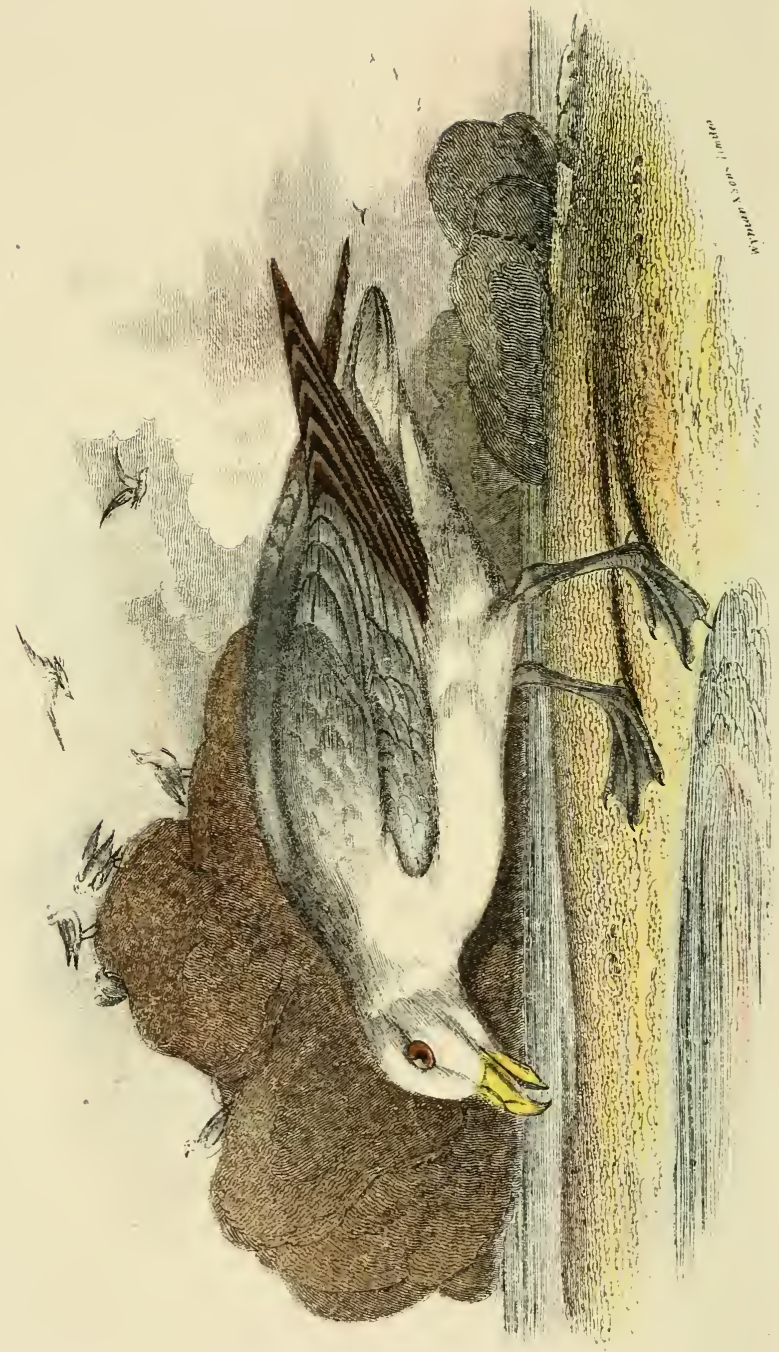

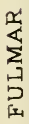


1. THE FULMAP. FULMARUS GLACIALIS.

Procellaria glacialis, Linı. Syst. Nat. i. p. 2 I 3 (1766).

Fulmarus glacialis, Margill. Brit. 13.v. p. 429 ( 1852$)$; Dresser, B. Eur. viii. p. 535, pl. 6I 7 (1878); B. O. U. List Brit. B. p. 199 (I883); Saunders, cd. Yarrell's Brit. B. iv. p. I (I884); Seebohm, Hist. Brit. B. iii. p. 430 (I 885 ); Saunders, Man. Brit. B. p. 7 I I (1889); Salvin, Cat. B. Brit. Mus. xxv. p. 425 (1896).

\section{(Plate CXI.)}

Adult Male.-General colour above light grey, with obsolete paler fringes to the feathers, the rump and upper tail-coverts delicate pearly-grey; wing-coverts like the back; bastardwing, primary-coverts, and quills dusky greyish-black, the shafts white, as also the inner web for two-thirds of its breadth ; secondaries grey, like the back, the inner web white, except at the end ; tail-feathers pearly grey, white on the inner web, and at the tips; head and neck all round, and entire under surface of body pure white, with a little shade of grey on the sides of the upper breast and on the lower flanks; under wing-coverts and axillaries white, the edge of the wing dusky-grey. "The curved point of the bill is yellow, the sides buff-yellow, those of the upper mandibles being more or less streaked with dark brown, the sheath investing the nostrils almost black; feet and legs bluish horn colour" (A. H. Cocks). Total length, 18.5 inches; culmen, I.65; wing, I ${ }^{\circ} \circ$; tail, $4 \cdot 1$; tarsus, $2 \cdot 2$.

Adult Female.-Similar to the male. Total length, 17.5 inches; wing, $13^{\circ} \circ$.

The Fulmar has also a dark phase, which is of a uniform dusky grey colour, a little paler on the under surface of the body. This is chiefly found in its more northern habitat, but in many places both light and dark forms occur together.

Characters. - In appearance the Fulmar is very like a grey Gull, but it may be distinguished by its tubular nostrils. There is no other Britisi Petrel with which it can be con. founded. 
Range in Great Britain.-The Fulmar breeds in some of the islands of the Hebrides, one notable breeding-place being S. Kilda. It also nests on Foula, in the Shetlands. Otherwise the species is a winter visitor to Britain.

Range outside the British Islands.-The present species is found in the North Atlantic from Baffin Bay and Greenland to Iceland, Spitsbergen, Novaya Zemlya, and Franz-Josef Land. In winter it comes south and occurs in America off the New England coast, and, according to Mr. Saunders, down to about Lat. $43^{\circ}$ in European waters.

Habits.-Mr. A. H. Cocks has given the following account of the Fulmar on the west coast of Spitsbergen :-

"At Magdalena Bay we found a 'White-Whaler' lying, with skins of this cetacean floating in the sea all round her, preparatory to being stowed away in her hold. Swarms of Fulmars were swimming close round the vessel's sides, elbowing and jostling each other, gorging on the scraps of blubber they obtained from the skins, and as tame as domestic poultry. We found we could catch them with a hook and line, baiting with a small scrap of 'spek,' literally almost as fast as we could haul them on board.

"On shooting some Ivory Gulls at this place, which dropped into the water, it was only by keeping up an unremitting cannonade of stones that I could keep the Fulmars off them until I could secure my specimens. They were common as far north as we went, and were among the few species of birds observed among the ice we met with about the latitude of Bear Island on our way south (4th of August). There were still a few every now and then after we were in sight of the Norwegian coast on the 6th, and the last I saw of this species was near the head of Lyngen Fjord (east of Tromso), on the $25^{\text {th }}$ of August. To the collector, the Fulmar Petrel is by far the most troublesome bird I have yet made the acquaintance of, from its habit, when shot, of ejecting an oily fluid from its mouth, which stains the plumage. I selected my specimens, and then took the utmost care in handling them, but one is never safe until the skin has been actually removed." 
Seebohm has given a good account of the species, as follows :-

"No bird is more thoroughly oceanic in its habits than the Fulmar. It lives exclusively at sea, often at great distances from land, and only visits some isolated ocean rock to rear its young. It follows in the track of the whalers, even to the limit of open water, to feast upon the scraps of blubber and the oil floating on the sea. It is an almost constant attendant upon the deep-sea fishing-boats, to prey upon the offal that is cast overboard, and is often so eager in its search for food as to allow itself to be caught by the hand. Large pieces of food are eaten whilst the bird sits lightly on the water, and tears them to pieces with its strong hook-shaped bill; but small morsels are either eaten at once or carried off to some distance, where they can be quietly devoured. The food of the Fulmar is largely composed of molluscs, cuttle-fish, and any garbage that it may find floating on the water, especially such that is of an oily nature. It also eats large quantities of sorrel; and the blubber of the whale is eagerly sought after.

"The Fulmar has great power of wing. It flies in a very similar manner to a Gull, and is generally mistaken for one of those birds, which it also closely resembles in the colour of its plumage. Parties of ten to twenty birds may often be seen following in the wake of the Atlantic steamers to pick up any food that may be thrown overboard from time to time. They never seem to tire, but fly backwards and forwards, crossing and recrossing the ship's stern, and often settling down one by one on the surface of the water to feed on anything eatable that they may descry floating on the waves. If a piece of meat be thrown to them they often seize it before it sinks, but instead of diving after it as a Duck or a Guillemot would do, they alight on the surface feet first, and in the most comical way let themselves sink down in the water with uplifted wings. They are rather stupid birds, and do not see half the food thrown out to them, but their power of continued flight is very marvellous. They follow a steamer going fifteen miles an hour against a head-wind of still greater speed with such ease that only an occasional flap of their wings is observable, and when the stern is reached they wheel 
gracefully round with the line of their long outstretched wings frequently brought for a moment at right angles to the surface of the water. In very wet weather they disappear; but half a gale of wind does not appear to interfere with their movements in the least, except that their wings are more actively employed, though even then they continually skim along with outspread motionless wings over the surface of the waves, bounding over their crests, and descending into the hollows. It is not to be supposed that the same individuals follow the ship across the Atlantic. On some days the number is very few, on others greater, and generally at sunset every bird disappears."

The following interesting account of the habits of the Fulmar on S. Kilda have been written by Mr. C. Dixon :-_" Most of the cliffs are broken, and all are more or less studded with grassy slopes, on most of which sheep graze in comparative safety. In many places, although the cliff is very precipitous, it is covered with grass, sorrel, and other plants, and a loose rich soil. It is in such spots that the Fulmar breeds in the greatest numbers. I shall never forget the imposing effect of this noble bird-nursery. Just before I reached one of the shoulders of Connacher, a few Fulmars were to be seen sailing in graceful flight above the cliff, then dropping down again into space. When I reached the summit the scene was grand; tens of thousands of Fulmars were flying silently about in all directions, but never by any chance soaring over the land; they passed backwards and forwards along the face of the cliff and for some considerable distance out to sea, whilst the waves a thousand feet below were dotted thickly with floating birds. The silence of such an aninated scene impressed me; not a single Fulmar uttered a cry, but lower down the cliffs Kittiwakes were noisy enough. No bird flies more gracefully than the Fulmar; it seems to float in the air without any exertion, often passing to and fro for minutes together with no perceptible movement of its wings; and I repeatedly saw a bird, head to wind, quite motionless for several seconds, the stiff breeze ruffling a few of its scapulars and neck-feathers. It is a remarkably tame bird, fluttering along within a few feet of you, its black eye glistening sharply against its snow-white dress. Sometimes I saw it hover like a Kestrel, or turn round 
completely in the air, as if on a pivot. But the Fulmars in the air are soon left to themselves, and a!l attention directed to those sitting quietly on their nests. In some parts of the cliffs, where the soil is loose and turf-grown, the ground is almost white with sitting Fulmars. Every available spot is a Fulmar nest; and as you explore the cliffs, large numbers of birds fly out from all directions where they had not previously been noticed. The Fulmar begins to lay about the middle of May, and I was told that the young are able to fly in July. It very rarely burrows deep enough in the ground to conceal itself whilst incubating, and, in the majority of cases, only makes a hole large enough to half conceal itself, whilst in a great many instances it is content to lay its eggs under some projecting tuft, or even on the bare and exposed ledge of a cliff, in a similar place to that so often selected by the Guillemot. I inagine that the bird makes a small excavation wherever it can; but there are not suitable places for all, and great numbers have to breed in unfavourable positions."

Nest.-Mr. Robert Read sends me the following note :"The Fulmar breeds in vast numbers in S. Kilda, where they usually lay their single white egg in hollows scraped out of the grassy turf covering the rocky terraces along the cliffs. Many, however, lay on the bare rocky ledges, where the egg is usually placed in a slight hollow or under a projecting piece of rock. In June, I888, I got along one of the narrow ledges to where a Fulmar was sitting, and at length managed to reach it with my stick. The bird would not stir for some time, but at last it ejected a stream of oil at the stick, and then flew off, leaving a single egg which I found, on blowing it, to be about a week or ten days incubated."

Eggs.-One. Chalky white and rough in texture. Axis, 2`75-3॰5 inches; diam., $1 \cdot 75^{-2} \cdot \mathrm{r}$.

THE PIED FULMARS. GENUS DAPTION.

Daption, Stephens in Shaw's Gen. Zool. xiii. p. 239 (I826).

$$
\text { Type, D. capensis (Linn.). }
$$

As in the true Fulmars the tail-feathers are fourteen in number in the genus Daption, but the bill is more slender, and 
the rami of the mandible are weak, the nasal tube being smaller, narrower, and lower at the base, less than the width of the latericorn. The tarsi are more slender than in Fulmarus.

One species only is known, which is universally distributed over the southern oceans.

\section{THE CAPE FUlMAR. DAPTION CAPENSIS.}

Procellaria capensis, Linn. Syst. Nat. i. p. 2 I 3 ( 1766 ). Daption capensis, More, Ibis., I882, p. 346 ; B. O. U. List. Brit. B. p. I99 (I883); Seebohm, Brit. B. iii. p. $45 \mathrm{I}$ (I885); Saunders, Man. Brit. B. p. 714, note (1889); Salvin, Cat. B. Brit. Mus. xxv. p. 428 (1886). Daption capense, Saunders, ed. Yarrell's Brit. B. iv. p. I I (1884).

Adult Male.-General colour above slaty-black, varied with white; the feathers grey at the base, but white sub-terminally, the feathers of the back with a triangular mark of slaty-black at the tip; scapulars like the back and marked in the same manner; lesser wing-coverts blackish-brown, the remainder brown, white at the base, and narrowly edged with white on the outer web, the inner greater-coverts pure white, some of them being brown at the end; primary-coverts and quills brown, white towards the base of the inner web; tail white, with a broad brown tip ; sides of face like the crown; a small white spot below the eye ; upper throat brown, with concealed white bases to the feathers; lower throat and sides of neck with brown ends to the feathers; remainder of under surface of body pure white, the under tail-coverts white, with brown tips ; under wing-coverts and axillaries white, the lower greatercoverts tipped with brown; the coverts along the edge of the wing blackish-brown; bill blackish-brown; feet dark brown; Total length, 15.5 inches; culmen, 1.35 ; wing, 10.5 ; tail, $4{ }^{\circ}$; tarsus, $1 \%$.

Adult Female.-Similar to the male. Total length, 14.5 inches; wing, $10^{\circ} 2$.

Young Birds.-Are apparently less spotted with white on the back; and have a more uniform brown throat. 
Characters.-Besides the generic characters given above, this species is unmistakable from its black and white spotted appearance.

Range in Great Britain.-Only one specimen has been noted from our seas, an individual having been recorded by Mr. A. G. More as killed near Dublin in October, I88I.

Range outside the British Islands. - This Petrel has been said to have occurred on three occasions off the coast of France. Otherwise it is known only as a strictly southern species, ranging as high as Ceylon and to about lat. $5^{\circ} \mathrm{S}$. on the coast of Peru.

Habits. -The "Cape Pigeon," as this bird is usually called, is a well-known inhabitant of the southern seas, where its habit of following ships is remarked by every ocean traveller. Mr. Gould, during his celebrated voyage to Australia, made the following notes:-_"This Martin among the Petrels is extremely tame, passing immediately under the stern and settling down close to the sides of the ship if fat of any kind or other oily substance be thrown overboard. Swims lightly, but rarely exercises its natatorial powers except to procure food, in pursuit of which it occasionally dives for a moment or two. Nothing can be more graceful than its motions while on the wing, with the neck shortened, and the legs entirely hidden among the feathers of the under tail-coverts. Like the other Petrels, it ejects, when irritated, an oily fluid from its mouth. Its feeble note of ' $c a c, c a c, c a c, c a c$ ' is frequently uttered, the third, says Captain Hutton, being pronounced the quickest. Its weight varies from fourteen to eighteen ounces; there is no difference in the weight of the sexes, neither is there any visible variation in their colouring, nor do they appear to be subject to any seasonal change."

Nest.- Sir Joseph Hooker states that this species was found by him breeding in Kerguelen Land. He says :- "It nests in sheltered ledges of cliffs about 50 or roo feet above the level of the sea."

Eggs.-Unkṇown, 
THE SHEARWATERS. SUB-FAMILY, PUFFININ.4.

These Petrels are distinguished by the absence of lamellæ on the side of the palate, a character which is developed in the Fulmars. Eight genera of Shearwaters are recognised, the genus Puffinus being found nearly everywhere throughout the seas of the world, whereas the allied genera, such as Priofinus, Thalasseca, Priocella, and Majaqueus, are inhabitants of the southern oceans. Estrelata and Bulweria are more widely distributed, and range into the temperate seas of the Northern Hemisphere.

THE TRUE SHEARIVATERS. GENUS PUFFINUS.

Puffinus, Briss. Orn. vi. p. I 3 I ( 1760$)$.

Type, P.puffinus (Linn.).

In these Petrels the tarsus is distinctly compressed, with its anterior edge sharp. The nasal tube is low, and both nostrils are visible from above, directed forwards and slightly upturned. There are twelve tail-feathers. (Cf. Salvin, Cat. B. Brit. Mus. xxv. p. 368.) Twenty species are known, distributed over the seas of both hemispheres.

I. THE GREAT SHEARWATER. PUFFINUS GRAVIS.

Procellaria grazis, O'Reilly, Voy. Greenland, p. I40, pl. 12, fig. I (18 i 8).

Puffinus major, Temm.; Dresser, B. Eur. viii. p. 527, pl. 6I 6 (1877); B. O. U. List Brit. B. p. 198 (1883); Saunders, ed.

Yarrell's Brit. B. iv. p. I 2 (1884); Seebohm, Hist. Brit. B. iii. p. 4I 7 (I885); Lilford, Col. Fig. Brit. B. part viii.

(г 888); Saunders, Man. Brit. B. p. 7I 5 ( I889).

Puffinus gravis, Salvin, Cat. B. Brit. Mus. xxv. p. 373 (1896).

Adult Male.-General colour above brown, with somewhat paler edges to the feathers of the back and scapulars, some of the latter having whitish margins; long upper tail-coverts mottled with white and having broad white tips; wing-coverts rather darker brown than the back, the greater series externally shaded with ashy-grey; quills dusky-blackish, with white at. 
the base of the inner web, increasing in extent on the secondaries, which are fringed with white at the ends; tail black, moderately wedge-shaped; crown of head uniform dark brown, scarcely forming a cap, though the hind-neck is lighter and shaded with grey, especially on the sides of the neck; lores dark brown; sides of face lighter and more ashy-brown; cheeks and under surface of body white, the centre of the abdomen sooty-brown; lower flanks and under tail-coverts also sootybrown, the latter tipped with white; under wing-coverts and axillaries white, the latter with sub-terminal spots of brown; bill dark horn-colour; feet yellow. Total length, 19.5 inches; culmen, $1 \cdot 9$; wing, $12 \cdot 6$; tail, $4 \cdot 7$; tarsus, $2 \cdot 25$.

Adult Female.-Similar to the male. Total length, 19 inches; wing, 12.5 .

Characters. - The tail is short and rounded, scarcely to be called wedge-shaped. The species is distinguished from the other Shearwaters by its large size, the wing being $12^{\circ} 5$ inches and upwards. Its brown back, with the lighter edges to the feathers, white breast, with the sooty-brown patch on the abdomen, are also distinguishing characters.

Range in Great Britain.-A more or less frequent visitor in England, sometimes occurring in some numbers off the southwestern coasts, but rarer on the east coast and off Scotland; of Ireland it has been frequently met with.

Range outside the British Islands.-The Great Shearwater occurs on both sides of the Atlantic from the Faeroes and Greenland southward to the Cape of Good Hope and the Falkland Islands. It is replaced by an allied species, $P$. kuhli, in the Mediterranean and on the Azores and Canaries. This species also occurs on the shores of North America and extends south as far as Kerguelen Land. The Great Shearwater has also been found in the Baltic round Heligoland.

Habits.-Mr. Howard Saunders writes :- "The food of this species consists chiefly of squid, and Mr. Gurney found the horny jaws of a cuttle-fish in the stomach of a bird shot near Flamborough; but any animal substance is greedily swallowed, and the species is systematically taken with a hook to furnish bait for fish. When alighting it strikes the water with great 
violence-in a manner quite different from that of a Gull-and then dives, pursuing its prey under water with great rapidity, and often tearing bait from the fishermen's hooks. When crossing the Atlantic, I have often seen them skimming the surface of the water without any apparent effort, alternately poised on either wing, but at times they flap their pinions freely."

Seebohm, who also observed the species during his voyages to America, has left us the following account of its habits :"In crossing the Atlantic in autumn the Great Shearwater is much more local than either the Fulmar or Wilson's Petrel. I have occasionally seen them approach very near the ship, but they never seemed to take any notice of it, nor did they follow the ship's wake or stoop to pick up anything that might be thrown out to attract them. Sometimes half-a-dozen may be seen together, but more often they are in pairs. Compared with the Fulmars they look very black, but as they turn so that the sun shines upon them, they look brown against the blue waves. Their under parts look almost white ; but as they skim up from the waves, the brown edges of the under wing-coverts can easily be seen. The white on the upper tail-coverts is conspicuous during flight, and the neck is shortened so as to produce the appearance of a white streak behind the earcoverts. It is impossible to ascertain during flight whether the under tail-coverts be white or not, as they are always covered by the outstretched feet. The Great Shearwater has even greater power on the wing than the Fulmar; he flies with the wings more bent, and seems to follow the surface of the waves still closer; he really does 'shear the water,' only now and then rising with a swallow.like flight above the horizon. $\mathrm{He}$ skims along the surface of the Atlantic billows with almost motionless wings, turning suddenly to avoid a breaker, or to follow some object floating on the water which has caught his eye, and which he sometimes snatches up without apparently lessening his speed. Wind or rain do not appear to incommode him in the least; he never seems tired. He is very rarely seen to alight on the surface of the water; he sometimes remains in sight for an hour together, but more often he passes on, and frequently not a Shearwater is visible during the whole day." 
Nest.-Nothing has been recorded of the breeding habits of the Great Shearwater.

Eggs.-Doubtless only one. The specimen figured in See. bohm's "Eggs of British Birds" (pl. 20, fig. 6), is probably not a genuine egg of the species.

\section{THE MANX SHFARIVATER, PUFFINUS PUFFINUS}

Procellaria puffimus, Linn. Syst. Nat. i. p. 2 I 3 ( 1766$)$.

Puffimus anglorum, Macgill. Brit. B. v. p. 44I (1852); Dresser, B. Eur. viii. p. 517, pl. 6I5 (I876); B. O. U. List. Brit. B. P. 197 (1883); Saunders, ed. Yarrell's Brit. B. iv. p. 2 I (I884); Seebohm, Hist. Brit. B. iii. p. 420 (I885); Saunders, Man. Brit. B. p. 7 I9 (I889); Salvin, Cat. B. Brit. Mus. xxv. p. 377 (1896).

Adult Male.-General colour above black, shaded with grey, and with obsolete grey fringes to the feathers of the upper surface; wing-coverts like the back, the greater series slightly browner ; quills black, shaded externally with grey, and lighter ashy on the inner webs; tail black; head and neck like the back; the lores and ear-coverts dusky blackish, with a little white below the eye; cheeks and sides of face and under surface of body, pure white, with blackish spots on the cheeks and blackish lines on the sides of the neck; the sides of the chest and sides of the upper breast dusky grey, and on the sides of the flanks a few blackish markings; the lateral under tail-coverts blackish along the outer webs; under wing-coverts white, as also the axillaries: "bill blackish horn-colour, the sheath of the under mandible greyish; legs and feet flesh colour, the back of the tarsus, outer toe, and lower outer half of middle toe, black; iris dark brown " ( $W$. R. Ogilvie.Grant). Total length, I4.8 inches; culmen, 1.45 ; wing, 9.5 ; tail, $3 \cdot 15$; tarsus, $1 \cdot 65$.

Adult Female.-Similar to the male. Total length, $14^{\circ} \mathrm{O}$ inches ; wing, $8 \cdot 8$.

Characters.-The Manx Shearwater belongs to the smaller members of the genus Puffinus, with a short tail and a wing 
not exceeding 9 inches in length. The primaries are wholly dark underneath. The upper surface is black, the axillaries white with a sub-terminal black mark, and the flanks and under tail-coverts are mostly white.

Range in Great Britain.-The Manx Shearwater is found in winter on most of our coasts, but breeds only in the Orkneys and Shetland Islands, the Hebrides, and in certain places on the west coast of England and Wales, as far south as the Scilly Isles. In Ireland, Mr. Ussher says that the species breeds on the headlands and islands of Donegal, Antrim, Dublin, Wicklow, Wexford, Kerry, and Mayo, and probably in other counties.

Range outside the British Islands.-The Manx Shearwater breeds in the North Atlantic Ocean, in Iceland and the Faeroes, extending to the coast of Norway and south to Madeira and the Canaries. On the American side it is also met with, and in winter extends south to the coasts of Brazil.

Habits.-Saxby has given the following account of the bird in his "Birds of Shetland":- " This interesting bird, the 'Lyrie-bird' of Orkney, usually arrives in Shetland at the end of April, or in the first days of May, and seems to lose no time in going to earth, being almost as truly a burrowing animal as any mole or rabbit. The earliest intimation of its arrival has repeatedly been brought to me by the folks who have taken it from the holes. Oddly enough, the fishermen, who have such abundant opportunities for observation, most positively assert that the bird is never seen abroad in the daytime. That they are wrong, I for one can testify. I have seen it at all times of the day, though, so far as I can remember, not during the breeding season. Indeed, as Mr. Robert Gray well remarks, there are few sights more picturesque in their way than that of a group of Shearwaters disporting themselves in a breeze of wind. The name of the bird seems to be derived from its strange habit of suddenly sweeping down towards the surface of the water, and ploughing it up with its breast. The splash of the Shearwater is quite unlike that of the Tern, and, although, of course, on a smaller scale, exactly resembles that 
caused by the graze of a round shot as it ricochets upon the water.

"The burrows are dug in the dry crumbling soil of the steep cliffs, varying from 18 inches to 2 feet in depth, or even more, and are so narrow that the introduction of the hand is a matter of some difficulty when the hole happens to be new, and therefore but little worn by the passage of the bird. A fresh hole is not necessarily dug every season, the old ones being often made to serve again. To look at, the bill would not seem to be very well adapted for digging; but still it answers the purpose, possessing more strength than the observer would, at first sight, imagine. The hooked point is very hard and sharp, as a certain scar on one of my hands can testify; and the edges of the mandible, too, are very keen, and have more than once drawn blood from my fingers. The sand is scraped out in sufficient quantity to form a considerable heap at the entrance, and very slight disturbance of the heap will cause desertion. Indeed, the Lyrie is not at all a bird that will bear to be much interfered with. It is almost certain to forsake the nest if it be taken out, even though it will return for the moment, creeping back into the hole after a little uncertain fluttering, seemingly quite bewildered when tossed up in the air.

"In handling the Shearwater, one need be very cautious, as it has the habit of ejecting from the mouth a quantity of clear thin oil, fishy and disagreeable enough, it is true, but by no means the abominably offensive stuff described by authors. On several occasions I have found in the stomach of this bird the jaws of a small species of cuttle-fish, vouched for as such by Mr. Gwyn Jeffreys himself, together with a small quantity of comminuted seaweed, and some green vegetable fibre. The cuttle-fish jaws have been found by me also in the stomach of the Fulmar Petrel."

A note by Mr. Drake, of Cardiff, is interesting, as showing the way in which the bird behaves when suddenly taken from its burrow:- " The Shearwater brought out was a beautiful bird, delightfully sleek and clean, with the charm and mystery of unfamiliar nature about it. None of the Shearwaters vomited the abominable oil which Petrels will sometimes emit. It was thrown up into the air, but bungled its restoration to 
liberty, seeming quite dazed, and was only too easily retaken. Again it was thrown up, and again it blundered, like an owl exposed to the noonday sun, only much worse. We found others, one of which I brought home alive; they all behaved in the same helpless way. We found their eggs, pure white and very like the Puffin's, but without its obscure maculation. These birds are so nocturnal in their habits that persons familiar with the island by daylight only might live surrounded by them and not suspect their presence. At night they come out and are active enough. It is then that their singular weird cry is uttered (why is the sea-bird's cry always melancholy?). I heard it as I lay awake in the tent. There was no noise of wings, no evidence of living, when a ghostly voice said in plaintive key, as of one who wept, 'Cuckolds in a row', with distinctest articulation; and again, as distance softened down its grief, 'Cuckolds in a row,' until, still further off, was echoed back, as if it passed some door that closed behind, 'Cuckolds in a row." "

Nest.-Saxby writes :- " In most cases, something of a nest is made with pieces of dead plants or hay, but sometimes the bare soil is thought sufficient. It now and then happens that the nest is made far back in the deep crevice of a rock. Some have asserted that the Shearwater lays only once in the season, but my own observations lead me to the conclusion that a second laying does take place; the bird, however, not producing a new egg-it lays but one-immediately on being robbed of the first, but waiting until the regular time, some weeks later, when it will either use the old burrow, to which it has returned occasionally in the interval, or will dig a new one. After the egg has been taken the bird will often remain in the nest for several days before finally resolving to quit. The young bird will keep on the nest until long after it is fully fledged, and in such circumstances becomes enormously fat, and is thought a dainty by the fishermen, who eat it with much relish."

Eggs.-One, white, Axis, 2.3-265 inches; dian., I'55175 . 
III. THE LEVANTINE SHEARWATER. PUFFINUS YELKOUANUS.

Procellaria yelkouan, Acerbi, Bibl. Ital. cxl. p. 294 (182 7 ).

Puffimus yelkouanus, Salvin, Cat. B. Brit. Mus. xxv. p. 379 (1896).

Adult Male.-Similar to $P$. puffinus, but rather paler and browner above; the flanks dusky brown, and the under tailcoverts usually dusky brown also. Total length, $15^{\circ} \mathrm{O}$ inches; culmen, $\mathrm{I} \cdot 5$; wing, $9 \cdot 1$; tail, $2 \cdot 7$; tarsus, $\mathrm{I} \cdot 8$.

Adult Female.-Similar to the male. Total length, 14.5 inches ; wing, $9^{\circ} \circ$.

Characters.-When the under tail-coverts are sooty-brown, this species is easily distinguished from the Manx Shearwater, with its white under tail-coverts. This character, however, seems not always to be constant, so that the characters for the identification of $P$. yelkouanus appear to be the brown lower flanks, and, above all, the greater length of the tarsus ( 18 inch), and the middle toe (1.95). In the Manx Shearwater the tarsus measures $\mathrm{I} 75$ inch, and the middle toe only I. 8 inch.

Range in Great Britain.-Two specimens of the Shearwater from Devonshire are in the British Museum, one from Torbay and another from Plymouth. The species probably occurs more often than is suspected, and has been confounded with the ordinary $P$. puffinus.

Range outside the British Islands.--This species is an inhabitant of the Mediterranean and Black Seas, but appears to wander north occasionally, when it visits the English coasts.

Habits.-Doubtless similar to those of $P$. puffinus.

Nest.-Doubtless in similar situations to that of the Manx Shearwater.

Eggs.-One. Doubtless similar to that of $P$. puffinus. 
IV. THE DUSKY SHEARIVATER. PUFFINUS OBSCURUS.

Procellaria obscura, Gm. Syst. Nat. i. p. 559 ( ( 788 ).

Puffinus obscurus, B. O. U. List Brit. B. p. 198 (1883);

Saunders, ed. Yarrell's Brit. B. iv. p. 27 (1884); Seebohm,

Hist. Brit. B. iii. p. 425 (1885); Saunders, Man. Brit.

B. p. 72 I ( 1889 ) ; Salvin, Cat. B. Brit. Mus. xxv. p. 382

(1896); Lilford, Col. Fig. Brit. B. part xxxii. (I896).

Adult Male.-General colour above slaty-black, with concealed greyish-brown bases to the feathers; wing-coverts like the back, with obsolete whitish fringes to the ends of the greater coverts; quills black, ashy along their inner webs; tail black; head and neck slaty black, like the back; lores also black; cheeks and sides of face, as well as the entire under surface of the body, pure white; upper eyelid white; the ear-coverts black, varied with white edges to the feathers, so that these parts appear as if streaked with white; the white of the neck ascending behind the ear-coverts; the sides of the upper breast mottled with black; lower flanks black; thighs and under tail-coverts white; under wing-coverts and axillaries white, the lesser under wing-coverts black at the base, and the edge of the wing mottled with black; bill dark hazel, paler on the mandible ; feet yellow, with the outside of the tarsus and outer toe black. Total length, I I. 2 inches; culmen, $\mathrm{I} \cdot{ }^{\circ} 5$; wing, 6.5 ; tail, 2.5 ; tarsus, $\mathrm{I} \cdot 4$.

Adult Female.-Similar to the male. Total length, I I'0 inches; wing, $6 \cdot 4$.

Characters.-The so-called "Dusky" Shearwater is not at all dusky in plumage, not more so than the Manx Shearwater, and like that species, it has a white breast. It may be distinguished by its small size (wing less than 8 inches), and by its pure white axillaries.

Range in Great Britain.-Two specimens of this species have occurred for certain within our limits. One was procured in May, 1853 , off Valentia Harbour in co. Kerry. In April, I858, another example was found dead near Bungay, in Suffolk. The species can, therefore, only be considered a rare and occasional visitor to Britain. Both the abovẹ- 
mentioned specimens appear to have been driven north by stress of weather, the first bird having been captured on board a small sloop, while the Suffolk specimen appeared to have been injured by hitting itself against a tree. A third example in the British Museum is said to have been shot in Devonshire. It was formerly in Mr. Gould's collection, whence it passed into that of Messrs. Salvin \& Godman (Cf. Salvin, Cat. B. Brit. Mus. xxv. p. 384 ).

Range outside the British Islands.-According to Mr. Salvin, the range of this species extends over the tropical and subtropical seas of the whole world.

Habits.-Colonel Feilden found this species breeding on " Bird" Rock, off Barbados.

Nest.-None. Laid in a hole in a rock (cf. Feilden, Ibis. I 889, pp. 6o, 5०3).

Eggs.-White. Axis, $2{ }^{\circ} \circ$ inches; diam., ${ }^{*} 4$.

V. THE SOOTY SHEARWATER. PUFFINUS GRISEUS.

Procellaria grisea, Gm. Syst. Nat. i. p. 564 ( 1788 ).

Puffinus griseus, Dresser, B. Eur. viii. p. 523, pl. 616 (1877); B. O. U. List Brit. B. p. I 98 ( 1883 ); Saunders, ed. Yarrell's Brit. B. iv. p. I 7 (I884); Seebohm, Hist. Brit. B. iii. p. 427 (1885) ; Saunders, Man. Brit. B. p. 7 I 7 (I829); Salvin, Cat. B. Brit. Mus. xxv. p. 386 (1896).

Adult Male.-General colour above sooty-brown, with a slight greyish shade on the edges of the feathers of the back, less distinct on the lower back and rump, which appear darker ; wing-coverts rather blacker than the back, with a greyish shade on the greater and primary-coverts; quills blackish, with a grey shade externally, the inner webs paler and more ashy; tail black; head sooty black, a little darker than the back; lores and sides of face like the crown; cheeks and under surface of body slaty grey, browner on the sides of body, abdomen and under tail-coverts; under wing-coverts white, with dusky shafts; axillaries sooty-brown, like the flanks; quills ashy below ; bill horn-colour; tarsi and toes dark hazel. Total length, I 8 inches; culmen, I.6 ; wing, I I.5 ; tail, 3.6 ; tarsus, $20^{\circ}$. 
Adult Female-Similar to the male. Total length, I 7.5 inches; wing, $12{ }^{\circ} \mathrm{O}$.

Characters.-The present species is distinguished by its sooty-brown colour, both above and below, the under wingcoverts being white with dusky shafts to the feathers.

Range in Great Britain.-An accidental visitor. "Identified examples have been," says Mr. Saunders, "obtained-in our summer and autumn-at North Berwick, in Scotland, and along the east coast of England, especially off Yorkshire; while several have been taken in the Channel as far west as Cornwall, though the bird is evidently less abundant there than its larger congener, $P$. gravis. In Ireland specimens have been secured on the coast of Kerry and in Belfast Lough, while others have been observed."

Range outside the British Islands.-According to Mr. Osbert Salvin, the present species is generally distributed throughout the seas of both hemispheres, from the Faeroe Islands in the North Atlantic, and the Kuril Islands in the North Pacific, to the Straits of Magellan and the Auckland Islands. Its breeding places are in the south, and its northward migrations are performed during the southern winter, when it straggles into the North Atlantic Ocean.

Habits.-Of the life of this Shearwater, but little has been recorded. Sir Walter Buller, in his "Birds of New Zealand," writes :-

"It is a common species in the New Zealand seas, and is said to be extremely abundant at Stewart's Island, and on the adjacent coast. It is also comparatively plentiful on the island of Kapiti, where it is found breeding as late as March. On the island of Karewa and on the Rurima Rocks, large numbers annually breed, sharing their burrows with the Tuatera Lizard, and submitting, season after season, to have their nests plundered by the Maoris, who systematically visit the breeding-grounds when the young birds are sufficiently plump and fat for the calabash.

"Mr. Marchant informs me that he found this species breeding in burrows near the summit of the island of Kapiti about the end of February. The excavations were in peaty 
ground, over which a fire had passed, destruying all the surface vegetation. The young at this time were half-grown, thickly covered with light grey down, and extremely fat. On being held up by the feet, oily matter ran freely from their throats. The old birds, on being taken hold of, fought fiercely with their bills. These birds are at all times more nocturnal than diurnal, and when hovering overhead at night, utter a frequent call-note, like tee-tee-tee, from which the Maori name is derived.

"There are several well-known breeding-places on the south-east coast of Otago, and on Stewart's Island, from which large supplies of potted birds are annually drawn and forwarded to the northern tribes, a poha titi (or cask of preserved Petrel) being a gift worth the acceptance of the highest chief."

Nest.-According to Mr. Travers' observations in the Chatham Islands, this Petrel makes a burrow in peaty groundrunning horizontally for about three or four feet and then turning to the right or left, while a slight nest of twigs and leaves at the extremity serves as a receptacle for the single egg. The male assists in the work of incubation, and the young birds, which are very fat, are esteemed a delicacy by the Maories, who hold them over their mouths in order to swallow the oily matter which is disgorged. The old birds roost on the shore, and are very noisy during the night. (Cf. Saunders, Manual, p. 18.)

Eggs.-One, white. Dr. II. O. Forbes gives the measurements of a series. Axis, $2 \cdot 7-3 \cdot 2$ inches; diam. $1 \cdot 82-2 \cdot 15$.

TIIE DOVE-LIKE FULMARS. GENUS (ESTRELATA.

CEstrelata, Bonap. Consp. Gen. Av. ii. p. 188 (I 855).

$$
\text { Type, } \text { E. hositata (Kuhl). }
$$

The genus Estrelata comprises about thirty species, mostly restricted to the southern temperate and tropical oceans, ranging north in the Pacific to Japan, and occasionally wandering to the latitude of the British Islands.

The number of tail-feathers is always twelve. The tarsi are not compressed as in the genus Puffinus, but are rounded on 
the anterior edge. The tail is moderate and rounded. The bill is rather short, stout, and black; the nasal opening is slightly directed upwards; the claw of the hallux small. (Cf. Salvin, Cat. B. Brit. Mus. xxv. p. 368).

\section{THE CAPPED PETREL. CESTRELATA HESITATA.}

Procellaria hasitata, Kuhl, Beitr. p. I42 (I 820 ).

Estrelata hasitata, Dresser. B. Eur. viii. p. 545, pl. 6i 8 (1880) ; B. O. U. List Brit. B. p. 200 (1883); Saunders, ed. Yarrell's Brit. B. iv. p. 8 (เ884); id. Man. Brit. B. p. 713 (1889); Salvin, Cat. B. Brit. Mus. xxv. p. 402 (1896).

Adult.-General colour above sooty-brown, with obsolete margins of lighter brown on the feathers of the back; the lower back and rump slightly blacker, as also the wing-coverts and scapulars; upper tail-coverts white; tail slightly wedgeshaped, black, with a good deal of white towards the base; crown of head blackish, forming a cap; hind-neck white, with a few sooty-brown bars on the nape; lores white; feathers below the eye sooty-brown; sides of face, ear-coverts, and under surface of body, white, with a little sooty-brown on the upper sides of the breast; a few of the lower flanks tipped with sooty-brown ; under wing-coverts and axillaries white, the lesser and marginal coverts blackish, forming a broad border to the inner aspect of the wing; lower primary-coverts white, tipped with black spots; quill-lining ashy; bill black; tarsi and toes yellow, the distal portion of the latter, and the webs for the same distance, black. Total length, $160^{\circ}$ inches; culmen, I.7; wing, II.3; tail, $3^{\circ} 8$; centre feathers, $5^{\circ}$; tarsus, $\mathrm{I}^{\circ} 5$.

Characters.-The distinguishing characters of this species are given by Mr. Salvin as follows :- " The exposed portion of the outer primary beneath is dark, not white; the bill is wide at the gape ; the under surface is white, as well as the back of the neck ; the crown is blackish, and the upper tail-coverts are white. (Cf. Salvin, Cat. B. Brit. Mus. xxv. p. 398.)

Range in Great Britain.-The only instance of the occurrence of this rare Petrel in Great Britain is that of a specimen taken 
청

喿

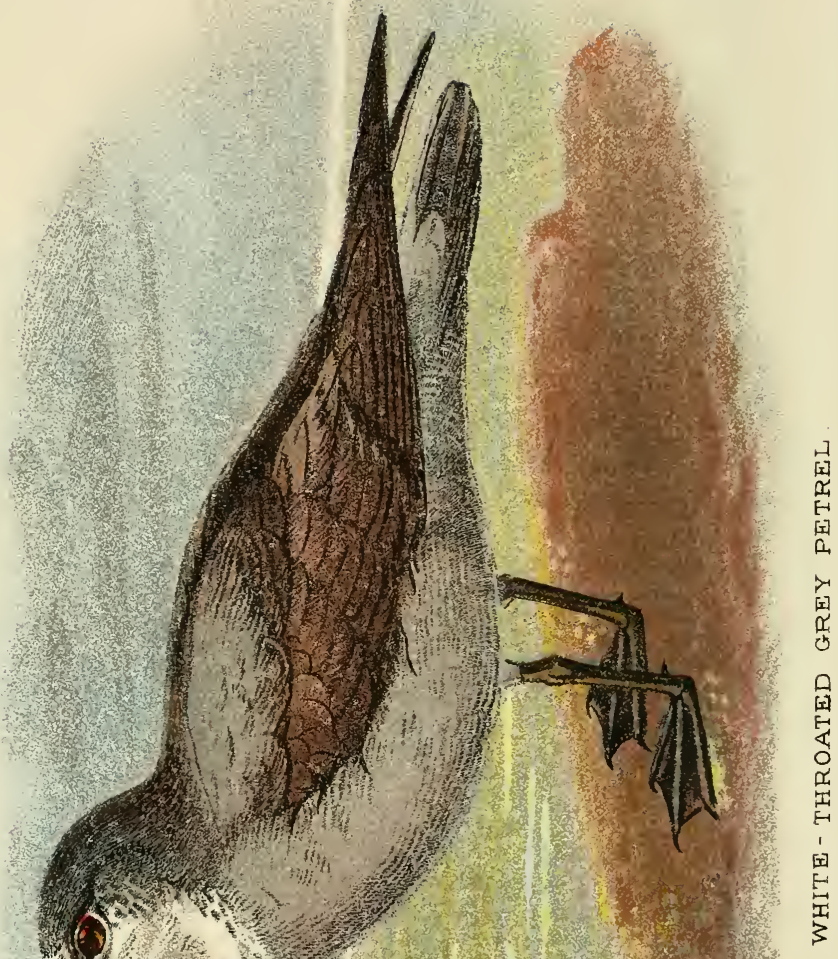


in Norfolk in the spring of 1850 . The specimen is in the collection of Mr. Clough Newcome.

Range outside the British Islands.-The habitat of the species is believed to be the islands of Haiti and Martinique, and probably Guadeloupe, in the West Indies, whence it occasionally wanders to European waters. The specimens existing in museums are very few. There is one in the Boulogne Museum, supposed to have been shot near that town many years ago. Another is in the Hungarian National Museum, believed to have been killed near Zolinki, in North Hungary. Four specimens are in Paris, three of which were sent by L'Herminier from Guadeloupe, and the Leiden Museum possesses an example, the history of which is unknown. A specimen was obtained in Eastern Florida in 1846 , and another was shot on Long Island in July, I850. This apparently completes the record of known specimens in collections, besides the single one from Haiti in the British Museum.

Habits.-Nothing has been recorded of the habits of this Shearwater.

Nest.-The breeding-places will probably be found to be in the high mountains of some of the tropical islands in the West Indies, where it nests, in all probability, in the same manner as the Blue Mountain Petrel of Jamaica, under boulders and rocks in the mountains.

Eggs.-Unknown.

11. THE WHITE-THROATED GREY PETREL. CES'IRELATA BREVIPES. Procellaria brevipes, Peale, U. S. Expl. Exp. viii. pp. 294, 337, pl. 80 ( 1848$)$.

Estrelata torquata, Macgill.; Salvin, Ibis. I 888, p. 359.

Estrelata breripes, Salvin, Cat. B. Brit. Mus. xxv. p. 408.

\section{(Plate CXII.)}

Adult.-General colour above slaty-grey, the scapulars, wingcoverts and quills browner, the greater coverts externally slatygrey; tail wedge-shaped, the feathers black, externally washed with slaty-grey; crown of head sooty-black, with the lores and 
forehead ashy-white, sprinkled with blackish; feathers below the eye dusky blackish; sides of face and entire throat white, with a few dusky frecklings on the ear-coverts and borders of the white throat ; under surface of body ashy-grey, lighter on the lower abdomen and under tail-coverts, the long coverts being whitish, freckled with grey; the chest darker and more slatygrey, the sides of the breast browner; axillaries ashy-grey; under wing-coverts white, the lesser and median coverts slatyhlack; quill-lining ashy-grey; bill black; tarsi and proximal half of the toes (except the outer one) yellowish, the rest black; Total length, $10^{\circ} 5$ inches; culmen, 0.95 ; wing, 8.1 ; tail, 3.8 ; tarsus, $\mathrm{I} \cdot \mathrm{I}$.

The above description is taken from the British specimen, which belongs to the dark form of the species. Some specimens, however, are white below and have a dark grey band across the breast.

Characters.-The present species belongs to the same section of the genus Estrelata as the preceding species. It has the dark outer primary and the wide bill of $\mathcal{E}$. hasitata, and the under surface is more or less white; the crown is slaty-black, and the upper tail coverts are grey; the under wing-coverts and axillaries are white, and the wing does not exceed 8.7 inches.

Range in Great Britain.-A single specimen of this small Petrel has been procured in England. Mr. Willis Bund, by whom the bird in question was presented to the British Museum, states that it was obtained on the coast in Wales between Borth and Aberystwith at the end of November or the beginning of December, I889.

Range outside the British Islands. - Until its occurrence on the British Coast this species was only known as an inhabitant of the Western Pacific Ocean. Specimens from the New Hebrides and the Fiji Islands are in the British Museun, and the original specimens of the species were obtained by Peale on the southern ice-barrier in lat. $68^{\circ} \mathrm{S}$.

Habits.-According to the late John Macgillivray, the "Katébu," as it is called in the New Hebrides, breeds on Aneiteum in burrows on the wooded mountain-tops in the 
interıor of the island, the highest of which attain to an elevation of 2,700 feet.

$$
\begin{aligned}
& \text { Nest. - None. } \\
& \text { Eggs.-Unknown. }
\end{aligned}
$$

THE BLACK SHEARWATERS. GENUS BULWERIA.

Bulweria, Bp. Cat. Net. Ucc. Eur. p. 8 I $(1842)$.

Type, B. bulweri (Jard. \& Selby).

The genus Bultereria differs from the other genera of the sub-family Puffinince in its long and wedge-shaped tail; the nasal tubes are fleshy at the end, the openings separate, and directed forwards and upwards. (Cf. Salvin, Cat. B. Brit. Mus. xxv. p. 368).

\section{BULWER'S PETREL. BULWERIA BULWERI.}

Procellaria bulweri, Jard. \& Selby, Ill. Orn. ii. pl. 65 (I $\delta_{30}$ ) ; Lilford, Col. Fig. Brit. B. part vii. (I888).

Thalassidroma bulaveri, Macgill. Brit. B. v. p. 449 (I852). Bulueria columbina (Webb \& Berth.), Dresser, B. Eur. viii.

p. 55 I, pl. 6 I 4 ( 1878$)$; B. O. U. List. Brit. B. p. 200 ( 1883 ); Saunders, ed. Yarrell's Brit. B. iv. p. 34 (I884); id. Man. Brit. B. p. 723 (1889).

Bulweria bulweri, Bp.; Salvin, Cat. B. Brit. Mus. xxv. p. 420 (1896).

Adult Male.-General colour above sooty-black, with a greyish shade over the head and back, the scapulars, wingcoverts and inner secondaries with obsolete brownish margins; greater coverts disiinctly ashy-grey externally; quills and tailfeathers black; under surface of body sooty-black, with an ashy shade ; the chin, upper throat, and fore-part of cheeks clear slaty-grey ; under wing-coverts sooty-black, like the breast, the greater coverts and quill-lining more ashy; bill black; the tarsi and base of toes greyish-pink, black for the terminal half of both toes and webs; iris deep brown. Total length, $10^{\circ} 9$ inches; culmen, 0.85 ; wing, 8.0 ; tail, 4.35 ; tarsus, $\mathbf{I}^{\circ} 05$.

Adult Female.-Similar to the male. Total length, 10.7 inches; wing, 7.8 . 
Range in Great Britain.-A single specimen of Bulwer's Petres is in the Museum at York. It was picked up dead on the banks of the Ure, near Tanfield, in Yorkshire, on the 8th of May, I 837 .

Range outside the British Islands.-The present species inhabits the temperate seas of the North Atlantic and North Pacific oceans. It is plentiful off Madeira, the Canaries, and the Salváges, but occurs again in the Sandwich Islands, in the Pacific, and ranges as far north as the islands of the Japanese seas.

Habits.-Mr. Ogilvie-Grant thus describes the species in the Salváge Islands :- “'The brownish-black Bulwer's Petrel was met with on Great Salváge. It is a common bird in the Madeira and Canary seas. IVe were too early for its eggs, but obtained four taken at the Lime Island, Porto Santo, and the Desertas, in the month of June. Our men used to catch numbers of this Petrel every night, and it was nothing for Manuel or Francisco to produce half a dozen each out of their shirts; but, with the exception of a few which we kept as specimens, the majority were allowed to escape. The call of this bird is very fine, and was frequently heard at night, a pleasant contrast to the harsh voices of the Great Shearwaters ; it consists of four higher notes, and a lower, more prolonged note; the whole repeated several (usually three) times, and uttered in a loud cheerful strain."

Mr. F. D. Godman, who visited the Desertas in $187 \mathrm{I}$, writes:- "It is curious to watch these birds crawling along the ground. They cannot fly unless they get to the edge of a rock; they waddle along on their feet, and, when they come to a steep place, they use the sharp-pointed hook of their beaks to draw themselves up with. They seem to dislike the light, and hide themselves under a rock, or crawl into a hole as soon as possible. I never saw one of this species flying about in the daytime, though some of the smaller ones are common enough."

Nest.-None. Mr. Godman found the birds sitting on their eggs, which were in holes or under rocks, and usually about as far in as he could reach with his arm. He says that these Petrels build no nest, but lay their eggs on the bare rock. 
Eggs.-One. Pure white, and nearly pyriform in shape. Axis, I'59-I.SI inch ; diam., I'1 2-I'28 inch (Osilvie Grant).

\section{THE DIVERS. ORDER COLYMBIFORMES.}

The skeleton of the Divers shows a very well-marked and curious character in the extension of the cnemial process of the tibia. The posterior process of the ilium is also approximated to such an extent that the sacrum is almost entirely concealed. There are no anchylosed vertebræ in front of the anchylosed sacral vertebræ, and the median xiphoid process of the sternum projects behind the lateral processes. The number of cervical vertebræ is fourteen or fifteen.

The palate is schizognathous, and there is no defined spinal feather-tract on the neck. Both the ambiens and femorocaudal muscles are present.

Besides these anatomical characters, the Divers are easily recognised by their long pointed bills and webbed feet, the hind-toe being on the same level as the other toes. The tarsus is compressed, and the feet have a curious backward position, so that it is impossible for the birds ever to stand upright on them. Considerable discussion has recently taken place on this subject both in England and America, but the entire concensus of opinion among field ornithologists of the present day appears to be that the Divers never attempt to walk, and that the most they can do on land is to shuffle to and from their nests with a seal-like motion of their bodies. I have been permitted by Mr. Abel Chapman to use the notes on the subject which he forwarded to our mutual friend Mr. Howard Saunders.

He writes:- "Loons and Grebes never sit upright on land. First, because they never go on to land, properly so called; and secondly, because they cannot sit upright if they tried ever so. Their legs will not bend that way. Cullingford* tells me that he always has to break the bones of the birds' feet when people insist on having their specimens mounted in an upright position." After some criticism of the figures in Yarrell's "British Birds," and those in other works on natural history,

* The well-known taxidermist of Durham. 
Mr. Chapman proceeds:- "I do not believe that Divers or Grebes ever go ashore at any time of the year. Some of them - 'scuffle' on their breasts for a few yards to their nests, which are never many feet from the water, not further than to avoid a bit of flood, and are generally at, or $i n$, it ; but this is just a 'Seal'-like progression, all legs and wings going, when the bird is alarmed at the nest; and the track to and fro is plainly visible. Beyond thus merely landing on some flat lake-shore or low islet, I never in my life saw either Grebe or Diver ashore, and never upright, or otherwise than absolutely horizontal. True, in the zeater, when swimming, they do sit upright to flap or 'yowl,' but never on land, because they cannot.

"They never go ashore to preen or dry themselves, in the warm sun, on sand-banks; they do all that afloat, and their whcle lives are spent afloat, though I have once or twice seen Red-throated Divers alongside the edge of a sandbank-but still quite afloat, and, of course, horizontal. They never let the tide ebb away and leave them dry, as Swans, Geese, and Game-Ducks always do, and even Diving-Ducks, as Scaup and Golden-eye, occasionally, but very rarely, do."

\section{THE TRUE, DIVERS. GENUS COLVMBUS.}

Colymbus, Linn. Syst. Nat. p. 220 (I 766 ).

Type, probably $C$. glacialis (Linn.).

The characters of the genus are those of the Order Colymbiformes, and of the single Family Colymbida.

The Divers are all birds of the Northern Palæartic and Nearctic Regions, coming a little to the southward in winter. Their general habits have been sketched in Mr. Abel Chapman's note given above.

I. THE GREAT NORTHERN DIVER. COLYMBUS GLACIALIS.

Colymbus glacialis, Linn. Syst. Nat. i. p. 22 I ( 7 766); Macgill. Brit. B. v. p. $283\left(185_{2}\right)$; Dresser, B. Eur. viii. p. 609, pl. 626 (1880); B. O. U. List. Brit. B. p. 201 (1883); Saunders, ed. Yarrell's Brit. B. iv. p. 96 (I884); Seebohm, Hist. Brit. B. iii p. 402 (1885); Saunders, Man. Brit. B. p. 693 (1889); Lilford, Col. Fig. Brit. B. part xxv. (1893). 
Adult Male-General colour above glossy black, spotted with white, the feathers being square at the tip, and ornamented with twin sub-terminal spots of white, larger and more conspicuous on the scapulars; wing-coverts like the back, but more feebly spotted with white, the spots being rounder and sometimes two in number near the end of the outer web; lower back and rump more distinctly greenishblack, minutely spotted with white; bastard-wing, primarycoverts and quills black, browner on the inner webs; upper tail-coverts and tail-feathers black; head black, with a purplish shade on the crown, changing to dull green on the sides of the head and neck; the sides of the hind-neck more distinctly purplish-blue ; sides of face and throat black, with a purple gloss on the chin, and the throat itself decidedly more green till it reaches an abrupt line, where it changes to a beautiful purple like the sides of the neck; across the middle of the throat a band of white feathers striped with black; a similar, but larger, band on each side of the neck; remainder of under surface, from the fore-neck downwards, white, the sides of the fore-neck and chest streaked with black, the sides of body and flanks black, with small white spots; across the line of the vent a narrow band of black; under tail-coverts black tipped with white spots; under wing-coverts and axillaries white, the latter narrowly streaked with black; the lower primary-coverts produced for half the length of the wings, white, broadly streaked with ashy-brown down the middle; quill-lining ashy-grey; bill black; legs and feet greenish-black; iris crimson. Total length, $28{ }^{\circ} 0$ inches; culmen, 3.2 ; wing, $14^{\circ} \circ$; tail, 2.5 ; tarsus, 3.35 .

winter Plumage.-Brown above, with a slight greenish gloss, the feathers sub-terminally dark in the centre and margined with ashy-grey, less distinctly on the lower back and rump, which are consequently more uniform; wing-coverts like the back, as also the inner secondaries; quills and tail blackishbrown; head and neck brown with a slight greenish gloss; the lores and sides of face brown; cheeks and under surface of body white, shaded with brown on the lower throat; sides of the neck brown with white edges to the feathers, producing a streaked appearance, the centre of the feathers darker brown; 
sides of the body brown, the feathers margined with ashy-grey like the back.

Young.--Similar to the winter plumage of the adult, but freckled with brown fringes to the feathers of the sides of the face, throat, and fore-neck. Immature birds can be easily distinguished by the more rounded shape to the feathers of the back.

Nestling.-Entire upper surface sooty-brown, a little lighter on the throat and chest; the under surface of the body white, with the sides brown like the back.

Range in Great Britain.-The Great Northern Diver is principally known as a winter visitor to the British Islands, when it occurs on most of the coasts, and occasionally on inland waters. It apparently breeds in the Shetlands, as the late Dr. Saxby noticed the species on a loch in Yell in June, and obtained eggs from there, which could only have been those of C. glacialis. Mr. Howard Saunders saw an adult bird on the r 9 th of July, 1879 , flying past his boat in Sulemvoe, and he adds :- "A few hours before leaving Lerwick I was assured on good authority that a very young specimen had just been brought in alive by the Earl of Zetland, a small steamer which then served the northern islands."

Range outside the British Islands.-The present species breeds in Iceland and in Southern Greenland, and across the whole of North America in the fur countries, as far south as the State of Maine. In Northern Russia and Siberia its place is taken apparently by $C$. adamsi. Like other Divers it comes south in winter, and at that time of year it is sometimes found on inland waters.

Habits.-The late Dr. Saxby, in his "Birds of Shetland," gives the following account of the species:- "Owing to the extreme watchfulness of this bird, and to its wonderful powers of diving, specimens are by no means easily obtained by a person who has not had considerable experience of its habits. The most favourable chance is when it is feeding under rocks which are sufficiently irregular to afford concealment to the shooter, who, it may be remarked, should in calm weather proceed very cautiously, or the bird will perceive him from an 
almost incredible depth, and, instead of rising near the anticipated spot, appear quietly swimming away far out of shot seaward. In smooth water, a boat and its moving shadow can be seen from beneath the surface of the water for a considerable distance, and hence the bird is most frequently dodged and shot during a breeze. The instant it perceives itself threatened with danger, it either sinks the body low in the water or entirely disappears, seldom emerging before it has traversed a distance of a hundred yards, or perhaps even five times that space, according to its idea of the extent of the danger. When once it has become thoroughly alarmed, further pursuit is generally hopeless, unless it happens to cross the track of the boat, as it will do occasionally, instead of proceeding in a line directly from it. When the bird chooses any other course than its favourite one, directly to the windward, a boat under sail in a stiff breeze will sometimes overtake it, but such a chance is rarely met with. Before its habits were so well known to me as they are now, I used to pursue it in a four-oared boat, but always unsuccessfully; lately, however, I have been able to get within range with a single pair of oars, but with a boat more manageable than those of the ordinary kind. As the boat approaches at first, the Diver sinks the body very low - so low, indeed, that the water covers the hollow of the neck; and the chances are that, when fired at, it will escape by diving, unless the favourable moment be selected when the bird submerges the head, or turns it aside, or rises to flap its wings. I have once seen it take wing immediately on being shot at, and on many occasions after emerging from a dive taken to avoid a shot. At any time it rises with great difficulty, and in calm weather especially is very awkward, splashing along the surface with wings and feet for a hundred yards or more, the attempt, as often as not, resulting in a return to its more natural element. The mode in which this bird dives cannot be easily explained in words. I have watched it most carefully, but always with an unsatisfactory result; it merely gives a slight start, if my meaning may be so expressed, and disappears in an instant. When wounded in such a manner as to be disabled from diving, it is a very awkward bird to handle. It will allow a boat to run close up without displaying any sign of activity; but the moment a 
hand appears in reach, there is a sudden splash with wings and feet, and such a thrust is delivered with the sharp bill that, if it take effect, it will probably interfere with the captor's shooting for some days afterwards.

"Its usual note bears considerable resemblance to the barking of a small dog; but upon a calm summer's evening I have heard it utter a long-drawn plaintive cry so strangely unlike any other known to me that I cannot even attempt to describe it. Upon the long-disputed subject of the capability of the Divers to sit erect, most observers confidently assert that they have seen it in that attitude. My own repeated disappointments have convinced me at least that a Cormorant having the under parts white has invariably been the cause of such impression."

Nest.-A rude affair of dead grass and water-plants, placed at a short distance from the water, and approached by a path worn by the passage of the birds to and fro.

Eggs.-Two in number. Ground - colour olive-brown or chocolate-brown, with black spots varying in size, and occasionally collecting round the larger end, the underlying spots indistinct and dark grey. Axis, $3 \cdot 4-3 \cdot 85$ inches; diam., $2 \cdot 1-2 \cdot 3$.

II. THE WHITE-BILLED DIVER. COLYMBUS ADAMSI.

Colymbus adamsi, Gray, P. Z. S. 1859 , p. 167 ; B. O. U. List Brit. B. p. 201 (1883) ; Seebohm, Hist. Brit. B. iii. p. 405 (1885); Saunders, Man. Brit. B. p. 695 (1889).

\section{(Plate CXIII.)}

Adult Male.-Similar to C. glacialis, but distinguished by the yellow or whitish bill and by the more distinct purple shade on the throat. The white streaks composing the transverse band on the throat are much broader and are not more than eight in number, whereas in $C$. glacialis there are more than twelve; the band on the lower neck is wider than that of C. glacialis, and consists of less than ten streaks of white, while in $C$. glacialis there are twenty of these white streaks. The lower back and rump are uniform, not spotted with white as in C. glacialis; bill whitish, a little dusky at the base. 



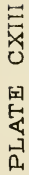

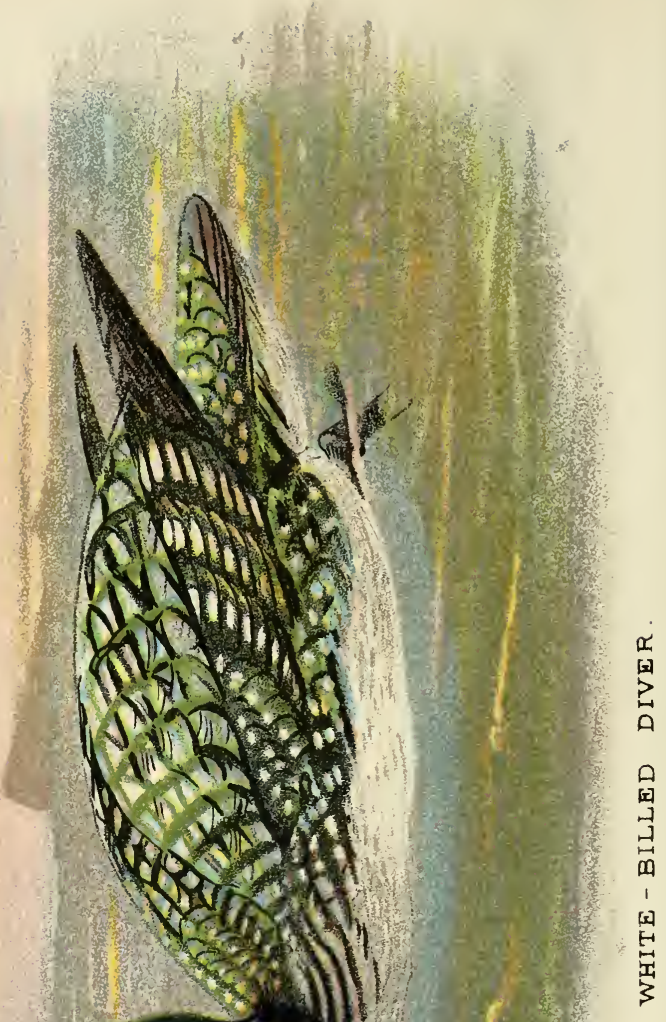


Total length, 29 inches ; culmen, $3 \cdot 7$; wing, $15 \cdot 2$; tail, 2.95 ; tarsus, $3 \%$.

winter Plumage. - Similar to that of $C$. glacialis, but distinguished by the ivory white bill. Upper surface brown, the feathers darker brown before the edges, which are light ashygrey and very broad; lower back and rump uniform brown; wing-coverts like the back, but not quite so distinctly margined; quilis and tail-feathers dark brown, the latter edged with ashy-grey like the upper tail-coverts; inner secondaries edged with ashy-grey like the scapulars; crown of head and neck dark ashy-brown; lores and sides of face white, like the under surface of the body, the sides of which are brown with ashy-whitish margins to the feathers.

Characters.-Professor Collett has given an excellent account of the sequence of plumage in the White-billed Diver, in the "Ibis" for I 894 (pp. 269-283, pl. viii.). This paper is especially to be commended to the notice of those ornithologists who imagine that there are few facts remaining to be discovered in the economy of European birds. It is a matter of regret to me that space prevents my reproducing his remarks in extenso.

Professor Collett point out that the young birds of the year have rounded or almost pointed feathers, instead of the squaretipped plumes of the old birds. In the following year the grey plumage is retained, and the worn winter feathering is still found in the ensuing June. After the next autumn moult the back is still grey, but the feathers are more square-cut, showing an approach to the adult form. The bill is white, like that of the old birds. When the birds are two years old the adult plumage is assumed, but it seems probable that, as is the case with $C$. glacialis, the birds do not breed in their first nuptial dress. Professor Collett has found that, in addition to freshmoulted feathers, some of the adult plumes are donned by a recoloration of the actual feather. For further details of the characters of $C$. adamsi the reader is referred to the paper itself.

Range in Great Britain.-That C. adamsi occurs more frequently off the British coasts than is usually supposed, is very probable, and now that attention has been called to the species, it will doubtless be found that many examples exist in collec- 
tions which have hitherto been supposed to be Great Northern Divers. The specimens actually recognised as British are, as yet, few, one from Pakenham, in Norfolk, being in Mr. Gurneys collection; another from Suffolk recorded by the late Dr. Babington; while a third is in the Newcastle Museum, from the coast of Northumberland.

Range outside the British Islands. - The White-billed Diver is believed to inhabit the whole of Arctic Russia and Siberia to the islands of Bering Sea and Alaska, down to Japan in winter; and Mr. Saunders believes that it is this species, and not C. glacialis, which is found in Jan Mayen Island, Spitsbergen, and Novaya Zemlya. The species was found by Nordenskjold, during the "Vega" expedition, breeding on Tschuktschiland, and Professor Collett believes that it visits the coasts of the North Sea in winter, coming from Siberia; he has examined several specimens from Norway. It also appears, like $C$. glacialis and other Divers, to visit inland waters, as Ritter Tschusi zu Schmidhoffen records it from Hungary. In North America it is found in the Arctic Regions to the west of Hudson's Bay, going south in winter, and occurring on the Great Lakes.

Habits.-These are supposed to be similar to those of C. slacialis, but little has been recorded on the subject. Professor Collett says that some of the Norwegian specimens were caught in nets in which they had been entangled when diving. The largest male in the University Museum at Christiania, from the Porsanger Fjord, was taken on a hook which was laid at a depth of about fifteen fathoms. In the specimens dissected by him, the stomach was filled with remains of fishes, and had a quantity of gravel in it. One contained an example of a full grown female, filled with roe, of Cottus scorpius. Dr. Stejneger, who found the species a rare winter visitant in the Commander Islands, obtained a specimen in a rather curious manner. He says :- "It was found sitting on the smooth ice of Lake Saranna (25th of November, 1882 ), unable to run upon or lift itself from the glib surface. It evidently had mistaken the transparent and shining ice for open water." Von Tschusi relates a similar mis'ake on the part of a flock of Coots, Fulica atra, L. (cf. J. f. O., I874, 
p. 343). Mr. Nelson, in his "Natural History Collections of Alaska," writes:- "During a sledge journey along this coast fragments of the skin were seen, usually comprising the skin of the neck divided, and with the beak in front, and thus fastened as a fillet about the bead, the long white beak projecting from the wearer's brow. Fillets made of this bird's skin in the same manner are commonly used by the natives of the coast just named, and about Kotzebue Sound. They are worn during certain religious dances held in winter, and are esteemed highly by the natives, from some occult power they are supposed to possess."

Nest.-The only record of the finding of the nest of the White-billed Diver, is that of Palander, during the voyage of the "Vega." He shot the female from the nest, on the 3rd of July, I 879, at Pitlekai, on the Tschuktschi Peninsula.

Egg.-Like that of Colymbus glacialis. Axis, 3.7 inches; diam. $2 \cdot 2$.

\section{THE BLACK-THROATED DIVER. COLYMBUS ARCTICUS.}

Colymbus arcticus, Linn. Syst. Nat. i. p. 22 I ( т 766); Macgill. Brit. B. v. p. $294($ I 852$)$; Dresser, B. Eur. viii. p. 6 I 5 , pl. 627 (1876); B. O. U. List. Brit. B. p. 201 ( $\left.188_{3}\right)$; Saunders, ed. Yarrell's Brit. B. iv. p. I05 (I884); Seebohm, Hist. Brit. B. iii. p. 407 (I885); Saunders, Man. Brit. B. p. 697 ( 1889 ).

Adult Male.-General colour above glossy black, spangled with white sub-terminal bars on the scapulars, very broad and distinct; on each side of the mantle a second longitudinal patch of white, formed by broad sub-terminal bars to the feathers; remainder of the back, rump, and upper tail-coverts black; wing-coverts black, with twin spots of white on the median and greater series; bastard-wing, primary-coverts, quills and tail black; head and neck dove-grey, slightly more slaty-grey on the forehead and region of the eye ; sides of face and ear-coverts sooty-grey; throat purple, brighter on the lower throat, the margin of which is abruptly defined on the fore-neck. Across the middle of the throat a band of white streaks, varied with eight streaks of black; sides of lower 
throat equally streaked with black and white, the black streaks very broad and extending to the sides of the neck; remainder of under surface of body from the fore-neck downwards pure white; the sides of the fore-neck and chest narrowly streaked with black and white; sides of the body glossy-black, the longer under tail-coverts black with white tips; under wingcoverts and axillaries white, the outer lower primary-coverts externally ashy; bills black; feet blackish; iris crimson. Total length, $22 \cdot 0$ inches; culmen, $2 \cdot 2$; wing, II 8 ; tail, $2 \cdot 1$; tarsus, $2^{\circ} 9$.

Adult Female.-Similar to the male. Total length, $2 \mathrm{I}^{\circ} \mathrm{O}$ inches ; wing, $\mathrm{II}^{\circ} 5$.

Winter Plumage.-Similar to that of the Great Northern Diver, but distinguished by the much smaller bill.

Range in Great Britain.-The Black-throated Diver breeds in the north of Scotland and in the Orkneys, but is not known from the Shetlands. It nests not uncommonly in Sutherlandshire and Caithness, and breeds also in the lochs of Invernessshire, Perthshire, Ross, and Argyll, as well as in many of the Outer Hebrides (cf. Saunders' Manual, p. 698). In winter it visits all the coasts of the British Islands, but is rarer than the other species of Diver, and mostly young birds are procured.

Range outside the British Islands. - The present species has a circumpolar distribution during the breeding season, nesting in the northern areas of both hemispheres, and migrating south in winter to the inland waters of Europe and the Mediterranean and in the east to Japan. At the last-named season it also extends its range to the Northern United States. It is not as yet known to occur in Greenland or Iceland.

Habits.-During the breeding season the Black-throated Diver frequents lochs and inland waters. In Norway it is by no means uncommon on the lakes of the higher fjelds, but the bird is not much in evidence during the day-time, though in the very early morning they were seen at Alfheim (1896) close to the house, swimming about in the lake, and making a considerable cackling. In the evening, as the days began 

3
0
$\frac{1}{2}$
$\frac{1}{2}$

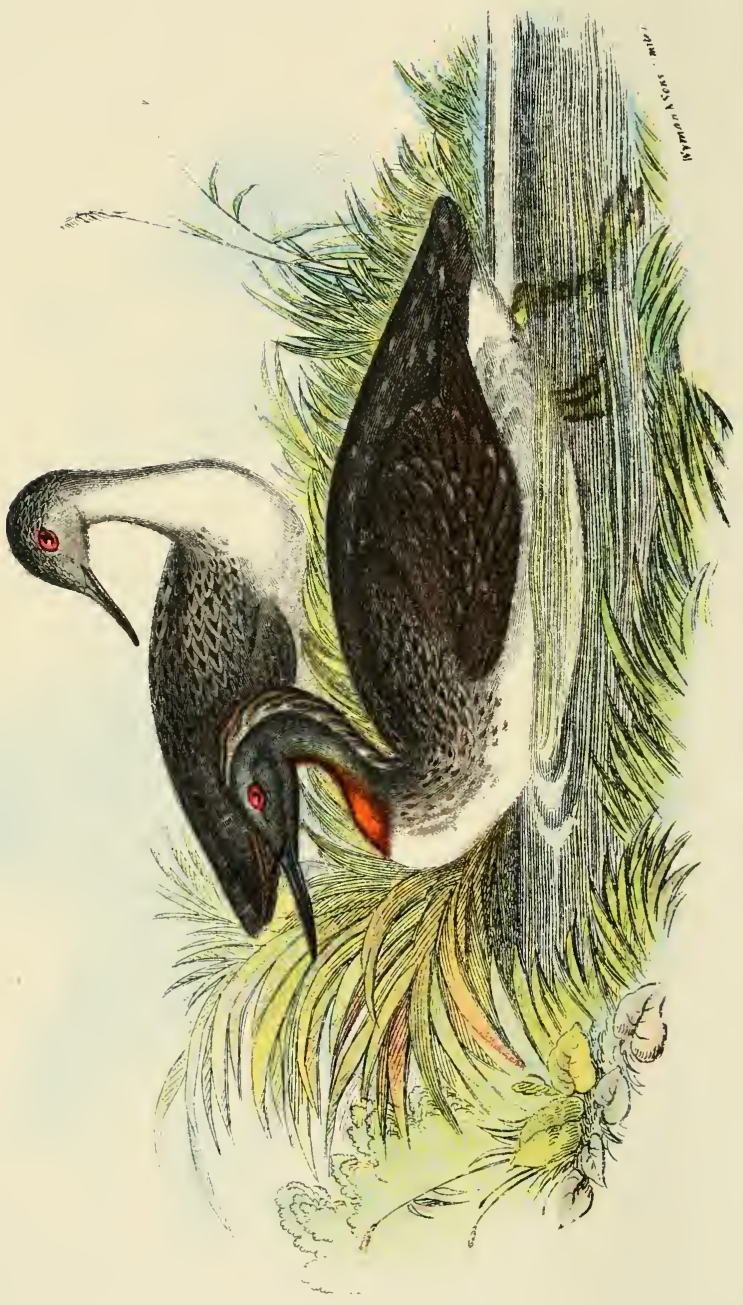

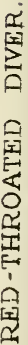


to close in at the end of July, the pair of birds which frequented our lake, used to take long flights overhead, flying at a tremendous rate with their long necks outstretched, and looking, in the dim twilight, like large Ducks.

Mr. Ogilvie Grant writes to me:- "As far as I have observed in Scotland, the habits of the Black-throated Diver are quite similar to those of the Red-throated Diver, on which I send you a note, but $C$. arcticus never breeds on the small lochs. All the nests I have seen have been placed on the sloping banks of islands in the larger lochs, where trout are to be caught in plenty."

Nest.-When in the water itself, the nest is simply made of dead grass and water-plants, but when on land there is no nest at all, or simply a few pieces of fresh sedge.

Eggs.- Two in number. Ground-colour clay-brown or olive-brown, sometimes light or very dark chocolate brown. The black spots are scattered over the whole surface, and are equally distributed, the underlying spots being black or greyishblack, and scarcely to be distinguished from the overlying ones. The dimensions of the eggs-axis, $3 \cdot 2-3 \cdot 5$ inches; diam., $I^{*} 9-2 \cdot 2$-overlap those of the Great Northern Diver, so that large eggs of $C$. arcticus cannot be distinguished from small ones of $C$. glacialis. Too much care, therefore, cannot be taken in their identification.

IV. THE RED-THROATED DIVER. COLYMBUS SEPTENTRIONALIS. Colymbus septentrionalis, Linn. Syst. Nat. i. p. 220 ( I 766 ); Macgill. Brit. B. v. p. 3 о I ( 1852$)$; Dresser, B. Eur. viii. p. 62I, pl. 628 (I876); B. O. U. List Brit. B. p. 202 (I883); Saunders, ed. Yarrell's Brit. B. iv. p. I I 2 (1884); Seebohm, Hist. Brit. B. iii. p. 4I 2 (I885); Saunders, Man. Brit. B. p. 699 (1889) ; Lilford, Col. Fig. Brit. B. part xviii. (1 891 ).

\section{(Plate CXIV.)}

Aduit Male--General colour above ashy-brown, with an oily green gloss, the feathers rather blacker in the centre, and sparsely spotted or edged with white, these spots less distinct 
on the lower back, rump, and upper tail-coverts, which are almost uniform; the back of the neck plentifully streaked with white and black, the green gloss on the latter being very distinct; wing-coverts brown, rather more distinctly edged and spotted with white; quills and tail blackish; crown of head and neck grey, obscurely mottled with dusky stripes on the former; the nape and hind-neck very distinctly streaked with black and white; sides of face, throat, and sides of neck clear slaty-grey, with a long triangular patch of vinous chestnut reaching from the lower throat to the fore-neck; remainder - of under surface of body white; the upper fore-neck and sides of chest streaked with black; sides of the body blackish, slightly spotted with white; the lower flanks and thighs sooty brown; under tail-coverts sooty-brown with white tips; under wing-coverts and axillaries white, the latter with dark shaft markings; bill black; legs and feet greenish black; iris hazel. Total length, 23.5 inches; culmen, $2^{\circ} \mathrm{I}$; wing, $10^{\circ} 9$; tail, $\mathbf{I} \cdot 8$; tarsus, $2 \cdot 65$.

Adult Female.-Similar in plumage to the male. Total length, $2 \mathrm{I}^{\circ} 5$ inches; wing, 10.8 .

winter Plumage.-Slaty-grey above, profusely speckled with white in the form of twin spots on the feathers, which are much smaller on the mantle, lower back, rump, and upper tail-coverts; the head and neck greyer and thickly streaked with narrow lines of dull white; lores, sides of face, and under surface of body white, mottled with black centres to the feathers on the sides of the fore-neck and chest; the sides of the body and flanks slaty-black, mottled and edged with white; under wing-coverts and axillaries white, with dusky brown centres along the latter; the lower primary coverts externally ashy.

Young Biras in Winter Plumage.-May generally be distinguished by a few dusky freckled edges to the feathers of the lower throat and sides of neck.

Nestling.-Covered with sooty-brown down, paler on the under-surface, which becomes white as the bird grows older.

Characters. - The very different summer plumage distinguishes the Red-throated from the Blue-throated Diver in the breeding 
season. The speckled upper surface of the body and the dusky streaks on the axillaries distinguish $C$. septentrionalis in winter.

Range in Great Britain. - This species breeds in Scotland from Argyleshire northwards, as well as in the Hebrides and the Orkney and Shetland Isles. "In Ireland," says Mr. Ussher, "one or two pairs have been discovered to breed on mountain lakes in Donegal, but as their eggs are regularly taken for collectors, the birds, if not so already, will soon be driven away. A pair may have bred in Sligo (Zool. I89o, p. 352)." In winter the Red-throated Diver is found on all the coasts of Great Britain, and not only ascends estuaries, but is sometimes observed far inland.

Range outside the British Islands.-The present species has a circumpolar distribution during the breeding season, and has been found as far north as $82^{\circ} \mathrm{N}$. lat. In winter it visits the Mediterranean, Black and Caspian Seas, and in Eastern Asia is known to occur in Japan, China, and Formosa. In America it migrates in winter across nearly the whole of the United States.

Habits.-I am indebted to my friend, Mr. W. R. Ogilvie Grant, for the following interesting note on the species:"In the north of Scotland I have, on many occasions, had opportunities of watching the breeding habits of the Redthroated Diver, and in May of 1896 I spent several whole days in observing the behaviour of a pair who had a nest with two partially incubated eggs on the edge of a small loch. This species almost invariably selects the small desolate lochs, often mere pools, situated in the more lonely and deserted parts, for purposes of nidification. In the north of Sutherland, where the country is a mass of lochs of every size and shape, there is much ground eminently suited to the habits of this Diver, but for some reason only a few scattered pairs avail themselves of this fine tract of country. The two eggs are always placed close to the water's edge, either on the margin of the loch, or on some tiny islet where the bank rises at a very gentle slope above the surface of the water. These birds are so curiously constructed-the legs being placed so far back on the long boat-shaped body-that, though admirably 
adapted for an aquatic life, they are apparently incapable of standing upright on land. When leaving the water to gain the nest, the bird lies on its belly, and slowly pushes itself up the gently-sloping peat or turf bank by using its legs alternately. Generally there are tivo distinct short 'runs' leading from the nest to the water, doubtless made by the bodies of the birds being dragged over the soft, wet ground as they change places during the period of incubation. The nest is merely a slight hollow in the wet bank pressed down by the body of the bird, sometimes imperfectly lined with a few bits of dead grass. On one occasion, being anxious, if possible, to secure the parent birds without shooting them, two carefully concealed gins were placed under the water just at the end of the 'runs,' so that it seemed an absolute certainty that the sitting bird must be caught by the legs either in going to or leaving the nest. This plan, however, utterly failed. Being hidden a couple of hundred yards off, we watched the female bird (for it was her turn on the nest) through the glass. Three times she settled herself comfortably on the eggs, and as many times we frightened her off. But on each occasion she passed over the traps without touching them, though the depth of water could not have been more than two inches. On leaving the nest the parent bird glides gracefully and quietly into the water, and, if danger has been sighted, almost instantly dives, with scarcely a ripple, re-appearing at a considerable distance from the nest. If the cause of uneasiness is near at hand, the body is sunk in the water till little more than the head and neck are visible, and it may easily be imagined that in rough water the birds are most difficult to see, even with the help of the glass.

"When unconscious of danger, the Divers float and dive and preen themselves much like Ducks, often raising themselves to semi-erect positions in the water, and flapping their wings. Some of the attitudes assumed by them when dressing their feathers are very curious. When preening the feathers of the sides and flanks, the birds turn half over, shewing the whole of the white sides of the breast and belly, and when sorting the feathers of the breast, they turn right over on their backs and float.

"This species differs from the Black-throated Diver in one 
particular, for it seldom, if ever, procures its food in the small lochs where it breeds.

"As a rule these pools are devoid of trout, and consequently, though one of the birds may frequently be seen swimming about while the other is engaged in hatching the eggs, all the fish are procured in the large lochs, which are sometimes a considerable distance away. Like the rest of its kind, the Red-throated Diver cannot rise very quickly from the water, but flaps along the surface for some distance before it gains sufficient impetus to be able to fly. When once on the wing and well under weigh, it travels at a great pace, the flight being very much like that of a duck. If disturbed from their nest the birds circle for some time high over the loch, the male uttering his hoarse cry, kork, kork, kork, kork, as he passes overhead, the sound reminding one somewhat of that of an old cock Grouse.

"It is marvellous how easily Divers may be overlooked on the water, especially when the surface is rough. I have often glassed a lock carefully from a distance of about a quarter of a mile, and been able to make out nothing, but on a nearer approach have found it to be tenanted by a pair of Divers. The keen vision of these birds evidently enables them to sight any suspicious object at a considerable distance, and we proved this to our satisfaction in the summer of ' 96 . A hen sitting on her nest at a distance of several hundred yards, instantly detected an incautious movement of the top of my head, which was the only part of my body visible.

"It may be worth while to add that a thoroughly trustworthy keeper in Sutherland assures me that a pair of Redthroated Divers, which we had watched together in the early summer of 1896, eventually bred among the heather at a convenient distance from the nearest pool. The shells of the two eggs were not found by him until the young birds had hatched off and were seen swimming, with the parents, in the loch hard by. There is every reason to believe this keeper's story, for he has known these Divers and their ways all his life, and had been trying hard to find the nest of this particular pair. If these birds really bred on land, and I have no reason to doubt the fact, the question is, How did they manage to alight on the ground, and, more wonderful still, when once there, how did they manage to get on the wing?" 
Nest.-Generally none, the eggs being laid upon the bare ground. Occasionally a slight foundation of dead sedge, or a little moss, is observable.

Eggs.-Two in number. Ground-colour dark olive, or dark chocolate-brown, the latter sometimes so deep in tint that the spots are scarcely discernible. Sometimes the eggs are covered all over with small black dots, in other instances the spots are larger and almost form blotches. On one egg in the British Museum there is a large blotch of brown. The underlying spots are blackish, or greyish-black, and are about as distinct as the overlying ones. Axis $2 \cdot 6-3 \cdot 05$ inches. diam. $I^{\cdot} 7-I^{\circ} 9$.

\section{THE GREBES. ORDER PODICIPEDIDIFORMES.}

The Grebes have the same remarkable projection of the cnemial process of the tibia as the Divers, and the same form of the posterior process of the ilium described under the heading of the last-mentioned birds. The palate is schizognathous, and the cervical vertebræ are seventeen to twenty-one in number: the anchylosed sacral vertebræ are preceded by a free vertebra, in front of which are four anchylosed dorsal vertebræ; the median xiphoid process of the sternum is abruptly truncated, so that the lateral processes extend behind it. The spinal feather tract is not defined on the neck, and the ambiens and femorocaudal muscles are wanting.

The bill is long and pointed, and resembles that of the Divers, from which the Grebes are at once distinguished by their lobed toes, and by their obsolete tail, which is not visible.

\section{THE TIPPETED GREBES. GENUS LOPHÆTHYIA.}

$$
\begin{aligned}
& \text { Lophaithyia, Kaup. Nat. Syst. p. } 72 \text { (1829). } \\
& \text { Type, L. cristata (Linn.). }
\end{aligned}
$$

Although I cannot follow the conclusions of my American colleagues in their determination of the generic names of Colymbus for the Grebes, and Urinator for the Divers, I must admit that their conclusion that the Little Grebe (Podicipes minor, auct.), must be considered to be the type of the genus Podicipes, seems to me to be indubitable. 
The genus Podiceps (potius Podicipes), was founded by Latham, in 1790 , and there is nothing in his characters to indicate any individual species as the type of his genus. The lobed feet, which he recognises as a character, are peculiar to all Grebes, and therefore the type of the genus can only be assured by elimination. The history of Latham's genus can, therefore, be traced as follows :-

\section{Latham, 7790.}

Lophaithyia, Kaup, I829...Podiceps cristatus.

" cayanus (ex Bodd. Pl. Proctopus, Kaup, $1829 \quad \ldots \quad$ \# auritus (nec Linn.) $=$ P. nigricollis, Brehm.

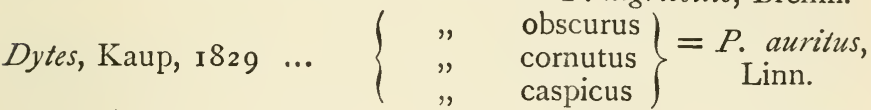
Podethyia, Kaup, $1829 \quad \ldots \quad " \quad$ ". rubricollis =P. griseigena , Bodd.

Podiceps, Kaup, I829 …

thomensis (ex Briss. Orn. vi. p. $\left.5^{8}\right)$.

" $\quad$ hebridicus (= P. minor, "suprii).

Podilymbus, Less, $183 \mathbf{1} \quad \ldots \quad$, $\left.\quad \begin{array}{l}\text { carolinensis. } \\ \text { ludovicianus. }\end{array}\right\}$

Kaup, in I829, split up the genus Podicipes, and fixed $P$. minor as the type, dividing the other Grebes under separate generic headings. I do not at present see any appeal from his decision, much as I regret the necessity of having to adopt his name Lophathyia for the larger European species.

As with the Divers, the habits of one Grebe are very like those of another, and it is consequently difficult to say anything that is new about their mode of life. They are all but cosmopolitan in their range.

The genus Lophathyia is distinguished from the smaller Grebes by the length of the bill, which is pointed, and measures from the gape more than the length of the inner toe and claw. 
I. THE GREAT CRESTED GREBE. LOPHÆTHYIA CRISTATA.

Colymbus cristatus, Linn. Syst. Nat. i. p. 222 ( I 766 ). Podiceps cristatus, Macgill. Brit. B. v. p. 250 (I852); Dresser, B. Eur. viii. p. 629 , pl. $629(1879)$; B. O. U. List Brit. 3.

p. 202 (r883) ; Saunders, ed. Yarrell's Brit. B. iv. p. i i 7 (I884); Seebohm, Hist. Brit. B. iii. p. 445 (I885);

Lilford, Col. Fig. Brit. B. part xviii. (I89I). Podicipes cristatus, Saunders, Man. Brit. B. p. 70 I (r889).

Adult Male in Breeding Plumage.-General colour above black, the feathers with obscure brown edges; scapulars and wingcoverts like the back, the lesser series forming a white band along the carpal edge of the wing; quills also black, the secondaries white, the inner ones white, externally more or less brown, and the innermost secondaries like the back; tail blackish; crown of head black, expanding into a crest or tuft of long plumes on each side of the nape; the lores white with a reddish tinge, continued in a narrow line over the eye; the sides of the crown, sides of face, fore-part of cheeks and ear-coverts, white; sides of hinder crown, hind part of ear-coverts and cheeks, orange-chestnut, tipped with black, forming a very wide frill, which nearly meets on the throat; entire undersurface of body silky white, with a tinge of vinous chestnut on the fore-neck and sides of body, the latter mottled with biackish centres to the feathers; under wing-coverts and axillaries white; "bill red; the bare space between the eye and the base of the bill blackish; legs and feet olive-green; iris crimson" (H. Seebohm). Total length, 20 inches; culmen, $2 \cdot 2$ : wing, $7^{\circ} 2$; tail, 1.6 ; tarsus, 2.4 .

Adult Female.-Similar to the male, but slightly smaller. Total length, I 8 inches; wing, 6.9.

winter Plumage.-The colour of the back and of the undersurface is much the same as in the summer plumage, but is a little greyer, and there is no ruddy tinge on the sides of the body, which are dusky brown. The wings are also the same at both seasons of the year. The red tippet, however, is lost, and the crown of the head is blackish, but the lateral crest is indicated by elongated feathers extending to each side of the nape; lores and a streak over the eye, white. In a male 
procured by Colonel Feilden in the Yarmouth market on the 2nd of November, there are signs of rufous and black on the sides of the neck. but whether these are remains of the last breeding-plumage, or the commencement of the next one, is difficult to determine. I believe them to be the last remains of the breeding-dress.

Young in First winter.-Resemble the winter plumage of the adults, but have broad white and black streaks on the sides of the head, one black line along the ear coverts and another below the eye being especially distinct. Seebohm says that these stripes on the head are moulted during the first autumn, when the bird resembles the winter plumage of the adult, but a specimen in the Hume collection, procured near Delhi on the I 4 th of January, not only shows these stripes very distinctly, but is also commencing to don the red tippet. The ornamental plumes worn by the young birds during their first spring are neither so large nor so bright as in old individuals.

Young.-Brown; the head, neck, and under-surface of the body white, with longitudinal black stripes on the upper parts and on the breast, two transverse stripes across the bill, and a grey patch on the sides of the head.

Characters.-The peculiar red tippet and white face, as well as the red bill, distinguish this species in summer plumage, as well as the larger size. L. griseigena, which might be confounded with it in winter plumage, is recognised by the want of the white eye-stripe.

Range in Great Britain.-The Great Crested Grebe breeds in some of the open meres of England, such as the Norfolk Broads, and certain lakes in I,eicestershire, Yorkshire, Shropshire, Cheshire, Lancashire, and Breconshire. Its most northerly breeding range in Great Britain appears to be in the neighbourhood of the Clyde, where Mr. Robert Read has discovered its nest. In winter it is shot on most of our coasts. Mr. R. J. Ussher states that in Ireland it "breeds on lakes, large and small, in Antrim, Down, Armagh, Monaghan, Fermanagh, Longford, Westmeath, King's and Queen's Counties, Clare, Galway, Roscommon, Sligo, and Leitrin. Several pairs inhabit some of the larger lakes." 
Tange outside the British Islands.-The present species is found over the greater part of the Old World, breeding in most countries of Europe and the Mediterranean basin, as far north as the Baltic provinces, Denmark, and Southern Sweden, across Siberia to Japan and China, and south to Australia and New Zealand. It occurs in winter throughout the Indian Peninsula in localities suited to its habits, but the African Great Crested Grebe seems to be different, and is known as Lophathyia infuscata (Salvad). It has not been recorded from any part of North America.

Habits.-Open waters are the principal localities affected by this Grebe during the breeding season, when its nest may be found far from the shore, a floating mass among the reeds. When the nest is approached, the birds generally swim away at a great rate, almost as fast as a boat can pursue them, and, on the latter appearing to gain on them, they take refuge in diving, seldom taking wing, though when called upon they are birds of strong flight, and fly with necks outstretched like a duck or a diver. Seebohm writes:-"Its food is entirely procured in the water, and consists of water-beetles and other aquatic insects, small fish, small frogs and molluscs. The seeds and tender shoots of aquatic plants are also often found in its stomach ; but instead of small stones or gravel, numbers of its own feathers, plucked from the ventral region, are mixed with its food. It is not known that this curious habit, which is more or less common to all the Grebes, is intended to assist digestion, but it has been remarked by many ornithologists in widely different localities-Nauman (father and son), Meves (father and son), Yarrell, Thompson, Macgillivray, \&c. Its ordinary alarm-note is a loud, clear $k e k, k e k$; but at the pairingtime another note, the call-note, may be heard - a loud, grating, guttural sound, like the French word croix.

"The Great Crested Grebe is decidedly a gregarious bird. When I was stopping at Stolp, in Pomerania, in r882, Dr. Holland was kind enough to pilot me to the Lantow See, a lake about four square miles in extent, and surrounded on three sides by pine forests. At one end of the lake was a large bed of reeds, and as we rowed towards it we saw quite a little fleet of Great Crested Grebes sail out. It was a most 
beautiful sight; there may have been thirty or forty of them. Every now and then one or two dived out of sight; occasionally a pair or two took wing; and by-and-by the rest flew away together, and, wheeling round, settled in the middle of the lake. Although it was the 3 oth of May the reeds had not attained a fourth of their ultimate height, and the Grebes had only just begun to breed. Many nests were empty, many contained only a single egg, and none of them contained more than two. Although the nests were exposed to the bird's-eye view of a passing Crow, on account of the smallness of the reeds, none of the eggs were covered.

"A week afterwards I found a very large colony of Great Crested Grebes on the Garda See, a lake close to the sea, about sixty miles west of the Gulf of Danzig. They were breeding in an immense reed-bed, and as our boat neared their nesting-grounds we saw the Grebes sailing majestically, not to say indignantly, out of the side of the reed-bed. As soon as we reached the place I put on my waders and was soon in a dense forest of reeds, where it was very easy to lose one's way. The water was above my knees, and the reeds were far above my head. After stopping to take the nest of a Great Sedge-Warbler with four eggs, I soon found the colony of Grebes. There were dozens of nests, but never very close to each other, and I soon filled my handkerchief with eggs. It was the $5^{\text {th }}$ of June, and only about half the nests contained the full complement of eggs. The birds had evidently seen us long before we approached, and had had ample time to retreat with dignity. In the nests which contained three or four eggs, they were warm and covered with damp moss; but in those containing only one or two they were uncovered and cold. This applied equally to the nests on the outskirts of the reeds, where the eggs could be seen by a passing Crow, and to those hidden in the depths of the reed-bed. The natural inference is that the eggs are not covered until the female begins to sit, and that the object of covering them is not protective, at least in the technical sense in which that word is used. The Grebes cover their eggs, not to conceal them from enemies, but to protect them from cold. In the recesses of a dense reedbed white eggs are as inconspicuous as in a hole in a tree or in a bank." 
Nest.-A floating mass of weeds. The one discovered by Mr. Robert Read in Renfrewshire, in 1889 , was built, he tells me, " amongst the rank herbage of a floating island, although the nest was not actially in the water like that of a Little Grebe. It contained three eggs, and, though they were about a week incubated, they were not covered up."

Eggs.-Three or four in number. Greenish-white, with a chalky covering, but as incubation proceeds they become stained, through contact with the decomposing weeds of which the nest is made, an ochreous or brown colour. Axis, $\mathbf{2}^{\circ} \mathrm{I}-\mathbf{2}^{\circ} 45$ inches; diam., I*4-I'55.

II. THE RED-NECKED GREBE. LOPHATHYIA GRISEIGENA.

Colymbus griseigena, Bodd. Tabl. Pl. Enl. p. 55 ( $\left.17 \delta_{3}\right)$. Podiceps rubricollis, Lath.; Macgill. Brit. B. v. p. 259 (I 852); Seebohm, Hist. Brit. B. iii. p. 459 (I 885 ).

Podiceps griseigena, Dresser, B. Eur. viii. p. 639, pl. 630 (I878) ; B. O. U. List Brit. B. p. 203 (1883); Saunders, ed. Yarrell's Brit. B. iv. p. I 24 (I 884 ) ; Lilford, Col. Fig. Brit. B. part xxvi. (1893).

Podicipes griseigena, Saunders, Man. Brit. B. p. 703 ( 1889 ).

Adult.-General colour above black, with a few remains of brown edgings to some of the feathers; wings blackish, with the lesser series white along the carpal bend of the wing; primaries black, the secondaries pure white, the innermost being blackish like the back; tail black; crown of head and hindneck glossy-black, with a greenish gloss, the feathers on the hinder crown developed into a hood ; sides of face, ear-coverts, and throat light slaty-grey, with a streak of white running from the angle of the mouth below the eye, above the ear-coverts and skirting the hinder edge of the latter, where the white broadens, but does not cross the throat; lower throat, sides of neck, and entire fore-neck, rich chestnut ; remainder of under surface of body silky white, the sides of the body chestnut, with dusky blackish tips to the feathers; vent brownish; under wing-coverts and axillaries, pure white; "bill black, but the lower mandible and the sides of the upper mandible yellow at the base; bare space between the eyes and the base of the bill 
reddish-black; legs and feet dull green, darkest on the joints ; iris, brownish-red" (Seebolmm). Total length, I5.5 inches; culmen, $\mathrm{I} \cdot 4$; wing, 6.3 ; tail, I.3 ; tarsus, $\mathrm{I}^{\circ} 9$.

Adult Female.-Similar to the male, but slightly smaller. Total length, 5 inches; wing, $6 \cdot 0$.

winter Plumage.-Differs in the want of all the ornamental plumes, the upper surface being blackish, with browner edges to the feathers; crown of head and neck blackish-brown, as also the lores and the sides of the crown; sides of face and under surface of body white, with the neck ruddy-brown, as well as the sides of the upper breast; the sides of the body and flanks spotted with dusky-brown.

Young in Down.--Upper parts dark brown, striped with white on the head and neck, and with pale-brown on the back; the under parts white, striped and spotted on the throat with dark brown (Seebohm).

Characters.-Adult birds are recognised from the three succeeding species by their larger size. The species cannot be confounded with $L$. cristata in summer plumage, as it has the face and throat grey without any rufous tippet.

In winter dress the two species are very much alike, but the want of the white lores and eyebrow distinguishes $L$. griseigena in winter and immature plumage from the corresponding stages of L. cristata.

Range in Great Britain.--The Red-necked Grebe is principally a winter visitor to our eastern coasts, and is rarely found on the western side of England and Scotland, and has only occurred some half-dozen times in Ireland. It is likewise seen on the southern shores of England, but more sparingly than on the eastern ones, though it is said to be not unfrequently met with in Cornwall.

Range outside the British Islands.-The present species breeds throughout Russia from Archangel to the Caspian and Black Seas, as far east as Turkestan, and westwards in the Baltic and Northern Germany to the South of Norway. To other parts of Europe it is a migrant, but Colonel Irby has seen young specimens from Marocco, and believes that they were reared in that country. In North America L. griseigena is replaced by a 
slightly larger form, L. holboelli, which ranges from Greenland westwards, and occurs in Eastern Siberia, varying south in winter to Japan and even reaching Turkestan, according to Severtzoff. This form is very doubtfully distinct from $L$. griseigena. It has a wing of $7 \cdot 2-8 \cdot 2$ inches, whereas the wing of L. griseigena varies from $6 \cdot 0-7 \cdot 3$ inches; thus it will be seen that the dimensions of the wing in these two forms overlap.

Habits.-Seebohm, who had opportunities of studying this species in its native habits, writes :- "In North Germany it is a very common bird, arriving late in March or early in April, and leaving again in October. It is almost exclusively an inhabitant of lakes and ponds, where sedge or reeds abound. On small ponds solitary pairs are found, but on the larger lakes great numbers breed together, though the nests are scattered up and down amongst the reeds, and not clustered together in a colony. The nests are sometimes placed in the recesses of the thick reed-beds, but quite as often they can be seen at a considerable distance in localities where the reeds are only half-grown and thinly sprinkled over the water. The nest is always floating, so that it can rise or fall with the water, and is considerably less than that of the Coot. It is somewhat carelessly made of reeds and decayed water-plants, and near each nest is a sort of sham nest, or foundation of a nest, merely a few reeds laid together, which is used as a roostingplace for the parent which, for the time being, is not occupied with the incubation of the eggs. Fresh eggs may be obtained during the first half of May. When the third egg is laid the bird begins to sit ; but it is ever on the look-out for danger, and long before the nest can be discovered, the approach of an intruder has been observed, the eggs have been carefully covered with black weeds to keep them warm, and the bird may be seen apparently feeding at a distance, looking as innocent and unconscious as possible."

Nest.-Made, like those of other Grebes, of reeds and decayed water-plants.

Eggs.--Three or four in number. Greenish-white, covered with a chalky substance when fresh, but becoming discoloured to a buff or brown shade. Axis $I^{\cdot} S_{5}-2^{2} I_{5}$ inches, diameter $1 \cdot 3-1 \cdot 4$. 

这

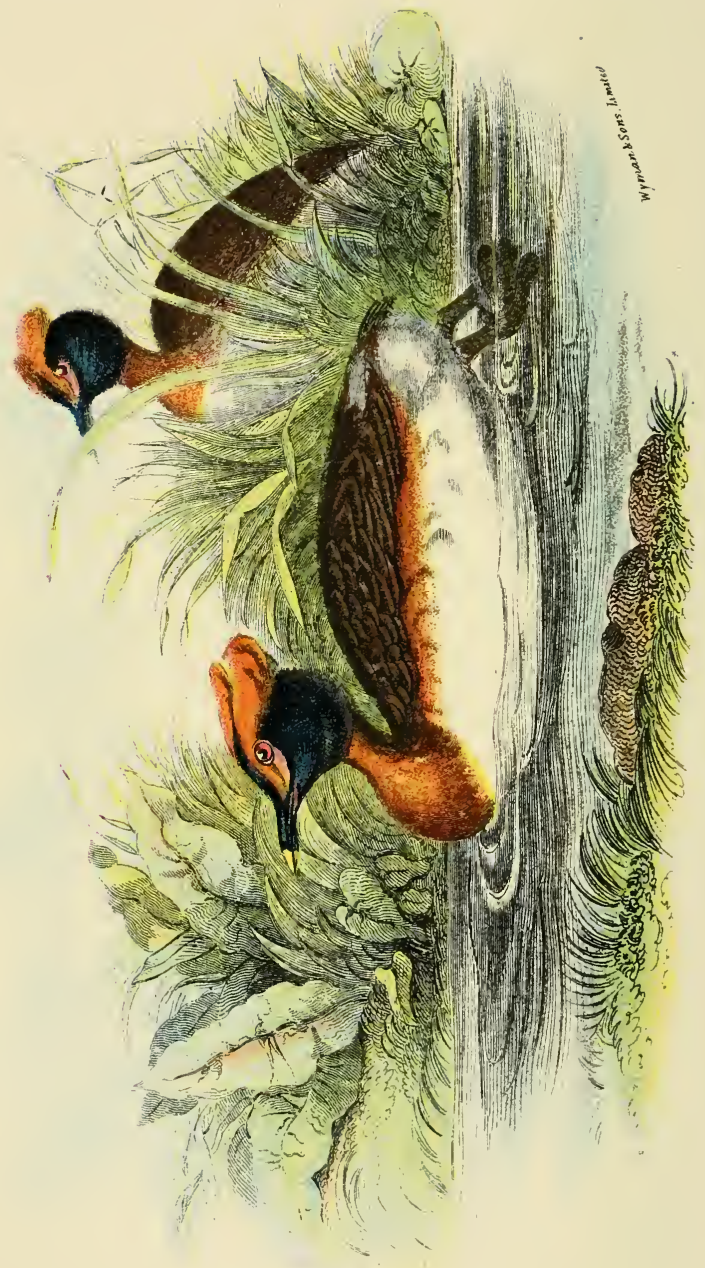


THE HORNED GREBES. GENUS DYTES.

$$
\begin{gathered}
\text { Dytes, Kaup. Natürl. Syst. p. } 49 \text { (1 } 829 \text { ). } \\
\text { Type D. auritus (Linn.). }
\end{gathered}
$$

The Horned Grebes have the bill shorter than in the Great Crested Grebes, the length of the bill from the gape being less than that of the inner toe and claw. The form of the bill, too, is stouter and rather more curved at the tip. The tippet, too, is more dense and entirely black, and extends over the entire throat, the feathers of which are full, the black tippet being surmounted by a band of crested plumes along the sides of the crown from the eye, forming a crest.

\section{THE SLAVONIAN GREBE. DYTES AURITUS.}

Colymbus auritus, Linn. Syst. Nat. i. p. 222 ( 1766 ).

Podiceps cornutus, Gm.; Macgill. Brit. B. v. p. 264 (1852); Seebohm, Hist. Brit. B. iii. p. 462 (1885).

Podiceps auritus, Dresser, B. Eur. viii. p. 645, pl. 631 (1879); B. O. U. List Brit. B. p. 203 (1883); Saunders, ed. Yarrell's Brit. B. iv. p. I 28 (1884); Lilford, Col. Fig. Brit. B. part xxvii. (1893). Podicipes auritus, Saunders, Man. Brit. B. p. 705 (1889).

\section{(Plate $C X V$.)}

Adult Male.-General colour above black, slightly varied with greyish edges to the feathers; wing-coverts ashy-brown, as also the quills, the primaries with dusky blackish tips, the secondaries pure white, the innermost secondaries black like the back; tail black; crown of head black, the hind-neck brownish black; the sides of the face and upper throat black, the feathers on the posterior part of the face being very long, and forming a frill round the back of the head, which is further ornamented by a broad superciliary band of chestnut feathers, rather paler and more tawny above the eye, this superciliary band produced backwards on the sides of the nape so as to form a dense tuft of horn-like plumes; the lower throat, foreneck, as well as the sides of the body, deep vinous chestnut, the feathers of the latter slightly varied with dusky blackish tips, the feathers near the vent also dusky brown; remainder of under surface of body silky white; under wing-coverts and 
axillaries pure white; "bill black, crimson at the tip and at the base of the under mandible; bare space between the eyes and the base of the bill crimson; legs and feet olive-green, palest on the webs ; iris crimson" (Seebohm). Total length, I 2.0 inches ; culmen, 0.9 ; wing, 5.5 ; tail, $\mathrm{r} \cdot 6$; tarsus, $\mathrm{I} \cdot 8$.

Mr. E. IW. Nelson says that specimens obtained by him near Nulato, in Alaska, had the eyes of the following brilliant colours :- "The ball of the eye white; a bright scarlet areola around the outer edge of the iris, which latter is defined by a white line. The iris proper is bright crimson, with its inner edge brilliant white shaded with pink. The pupil consists of a central black spot, with a broad ring of dark purple."

Adult Female.--Similar to the male. Total length, II'5 inches ; wing, $5^{\circ} 6$.

winter Plumage.-General colour above blackish, slightly shaded with grey on the edges of the feathers; the head devoid of ornamental plumes; crown and neck black, the feathers of the former a little full towards the nape; lores and sides of crown to the line of the eye black; throat white, like the side of the face, and extending on to the sides of the neck; remainder of under surface of body silky-white, with a little dusky brown on the lower throat below the line of the tippet, which is indicated by the white feathers of the throat and face; sides of neck blackish-brown; sides of body mottled with greyish-black tips to the feathers; "bill dark horny, pinkish towards the base, paler at the tip; tarsi and feet pearly-grey, outer sides of tarsi, outer toe, and joints blackish ; iris bloodred" (IV.R. Osilvie Grant).*

Young Birds in Winter.-Resemble the adults, but are much browner, especially on the flanks and lower abdomen; sides of face dusky-white, not pure white as in the adults; feathers under the eyes and lores black; feet, in dried skin, with a good deal of yellow about the toes.

Characters. - The old birds are distinguished from the other British Grebes by the black head and tippet, the tawny chestnut bands forming the crest on each side of the crown, and the deep chestnut throat and fore-neck. In winter the resem-

* On the changes of plumage in this species, cf. J. G. Millais, Ibis, I $896, \mathrm{pp} .454-457$. 
blance between $D$. auritus and P. nigricollis is closer, but the upturned bill of the latter and the white on the inner primaries will almost distinguish it.

Range in Great Britain. - This Grebe is a winter visitor to Great Britain, occurring on both east and west coasts of Scotland, but in England and Ireland being much more seldom met with on the west and south. On the east coast of England it is a regular winter visitor.

Range outside the British Islands.-The Slavonian or Horned Grebe nests throughout Northern Europe and Siberia, as well as in Iceland. It also occurs throughout North America, where it breeds from the United States northward. It nests sparingly in Denmark, and ranges south over Europe in winter, when it visits the Mediterranean, while at the latter season it has been known to reach the Bermudas.

Habits.-The late Mr. Proctor, who visited Iceland in I837, has given the following account of the species:- "This bird frequents the fresh waters, and nests amidst the reeds and other rank herbage. The young birds, when first hatched, are covered with grey-coloured down. No sooner does the old bird perceive danger from any intruders than she instantly dives and emerges at thirty or forty yards distance. One day during my sojourn in Iceland, having seen one of these birds dive from the nest, I placed myself with my gun at my shoulder, waiting for its reappearance. As soon as it emerged, I fired and killed it, and was surprised to see two young ones, which it seems had been concealed beneath the wings of the parent bird, drop upon the water. I afterwards shot several other birds of this species, all of which dived with their young under their wings. The young birds were placed with their heads towards the tail, and their bills resting on the back of the parent bird."

Seebohm relates that the well-known naturalist, Dr. Krüper, once found a nest, the eggs of which were highly incubated, and listened to the cries of the female on the nest, while the male attempted to frighten him away by suddenly rising out of the water in front of him, splashing with his feet in the water, and ioining his cries to those of its mate. So persistent was it 
that Krüper returned to the shore for his butterfly-net, and when the performance was repeated, caught the bird in it.

Nest.-Described by Proctor as large, floating on the surface of the water, with which it rises and falls; it is composed of a mass of reeds and other aquatic plants. Dr. Krüper states that he has occasionally found the nest on a tussock of grass in the water, and once on a stone.

Eggs.-From two to four in number, and sometimes, according to Seebohm, five. They are not to be distinguished from those of the Black-necked Grebe, and are of a greenish-white colour with the usual chalky covering. Axis, I.65-1.95 inch; diam., $\mathrm{I} \cdot 2-\mathrm{I} \cdot 35$.

\section{THE EARED GREBES. GENUS PROCTOPUS.}

Proctopus, Kaup. Natürl. Syst. p. 49 (1829).

Type, P. nigricollis (C. L. Brehm).

The shape of the bill, which is upturned at the end, instead of being straight as in Dytes, distinguished the genus Proctopus from the last-named genus. The bill is, moreover, depressed at the base, being wider than it is deep; whereas in Dytes the contrary is the case, and the bill is deeper than it is wide at the base. The ornamental tufts on the head also are hairy in appearance rather than plumose, and spring from the region of the ear-coverts.

I. THE BLACK-NECKED GREBE. PROCTOPUS NIGRICOLLIS.

Podiceps nigricollis, C. L. Brehm, Vög. Deutschl. p. 693 (I83 I); Dresser, B. Eur. viii. p. 651, pl. 632 (1878); B. O. U. List Brit. B. p. 204 ( 1883$)$; Saunders, ed. Yarrell's Brit. B. iv. p. 133 (1884); Seebohm, Hist. Brit. B. iii. p. 465 (1885) ; Lilford, Col. Fig. Brit. B. part xxv. (1893). Podiceps auritus, Gm. (nec Linn.); Macgill. Brit. B. v. p. 270 (1852).

Podicipes nigricollis, Saunders, Man. Brit. B. p. 707 (1889).

Adult Male in Breeding Plumage.-General colour above black, with a slaty gloss; wing-coverts like the back; quills sootyblack, with darker ends to the primaries, the inner primaries 
with white on the inner webs, secondaries entirely white, except the innermost, which are like the back; tail black; head and neck black, the crown having a frill composed of elongated feathers; the ear-coverts chestnut and composed of elongated plumes, which are surmounted by a superciliary tuft of similar elongated feathers of a golden straw-colour, this tuft starting from the eye; cheeks and entire throat black; remainder of under surface, from the fore-neck downwards, silvery white; the sides of the body slightly mottled with blackish markings, and having also chestnut-tipped feathers, especially developed on the sides of the rump; under wingcoverts and axillaries white; "bill black; bare space between the eye and the base of the bill reddish-black; legs and feet olive-green, paler on the webs; iris crimson" (Seebohm). Total length, $12^{\circ} \circ$ inches; culmen, $0^{\circ} 95$; wing, $5^{\circ} \circ$; tail, ${ }^{\circ} 35$; tarsus, $I \cdot 7$.

Adult Female.-Similar to the male. Total length, I I inches; wing, $5^{\circ} \mathrm{I}$.

winter Plumage.-Blackish above, with slightly greyer edges to the feathers; head and neck blackish, as well as the lores and feathers below and behind the eye; sides of face, ear-coverts, and under surface of body silky white, the sides of the body mottled with ashy-blackish ends to the feathers; sides of upper neck white; sides of lower neck dusky-brown, meeting across the fore-neck and forming a collar; wings dark brown, the secondaries white, with the exception of the innermost, which are white only on the inner web, the last ones being like the back; the inner primaries white along the inner web.

Characters. - In breeding plumage the Black-necked Grebe is distinguished by the black fore-neck and chest, which resemble the throat, though sometimes the chest shows a little rufous, but never anything like the entirely chestnut chest of $D$. auritus. The tuft of crest-feathers behind the eye is darker chestnut and more hairy in texture. In winter plumage the up-turned shape of the bill and the white on the inner primaries distinguish $P$. nigricollis, and the same characters may be employed for the determination of immature birds.

Range in Great Britain.-The present species is a bird of Southern Europe, and occurs more frequently in spring and 
summer, being of rare occurrence in autumn and winter. It is, therefore, more frequently met with on the south coast of England, and on the east, while it is believed to have bred in Norfolk, as the late E. T. Booth had an adult bird and two nestlings brought to him by a marshman some years ago. On the west coast of England, as well as in Scotland and Ireland, the records of the capture of the species are less numerous.

Range outside the British Islands. - This species is an inhabitant of Central and Southern Europe, nesting abundantly in most of the countries of the Mediterranean and Black Seas, and being found in great numbers in Northern Africa. It appears to nest in Abyssinia, and again in Southern Africa, both in the Cape Colony and the Transvaal. It has been said to breed in Denmark, and to have wandered as far north as Iceland. In Asia it is met with over the temperate regions to Korea and Japan, and in winter it is found in China, and has also been procured by Mr. A. O. Hume on the Mekran coast in February.

Habits. - The Black-necked Grebe is usually considered to be a much shyer bird than the Slavonian Grebe, and seeks safety in diving rather than by flight. Naumann describes its note as a high soft, but far-sounding, beeb, which, in the pairing season, is rapidly repeated, and becomes a trill bidder, vidder, vidder, vidder. The food and habits of this Grebe otherwise resemble those of the other members of the family.

Nest.-Made of reeds and rotten water-plants ; but, accurding to Canon Tristram, they are in Algeria sometimes raised on artificial islets, frequently almost touching each other, and sometimes piled on stout foundations rising from more than a yard under water. In Denmark, Mr. Benzon says that the nests were made chiefly of moss, with which the female covers up her eggs on leaving them. Mr. Thomas Ayres, who has found this Grebe breeding in the Transvaal in December, says that "the nest is found in shallow lagoons, in two or three feet of water, among the rushes. The nests, which float on the water, are formed of a mass of rushes about a foot in diameter, and two or three inches out of the water. On leaving the nest, the old bird always carefully covers the eggs with rushes, and any person unacquainted with this habit would pass the 
nest as an unsightly heap of rotten wood. The eggs are often much discoloured from being immersed in water; but this does not appear in any way to injure them, or to prevent them from hatching in the usual way."

Eggs.-Three to five in number. Greenish-white in colour, with more or less of a chalky covering. Axis, I $65^{-1} \cdot 95$ inches ; diam., $I^{\prime} I_{5}-I^{*} 3$.

THE LITTLE GREBES. GENUS PODICIPES.

Podiceps, Kaup, Natürl. Syst. p. 49 (1829); ex Lath. Ind. Orn. ii. p. 780 ( 1790 ).

Ty pe, $P$. fluviatilis (Tunst.).

In this genus the tarsus is shorter than the middle toe and claw. All the species are of small size, and the distribution of this genus is all but cosmopolitan.

I. THE LITTLE GREBE. PODICIPES FLUVIATILIS.

Colymbus fuviatilis, Tunstall, Orn. Brit. p. 3 ( I 77 I).

Sylbeocyclus europaus, Macgill. Brit. B. v. p. 276 (1852).

Podiceps fluviatilis, Dresser, B. Eur. viii. p. 659, pl. 633 (г880);

Saunders, ed. Yarrell's Brit. B. iv. p. I 37 (1884).

Tachybaptes fuviatilis, B. O. U. List Brit. B. p. 204 (1883).

Podiceps minor, Briss. ; Seebohm, Hist. Brit. B. iii. p. 468

(1885) ; Lilford, Col. Fig. Brit. B. part xx. (189r). Podicipes fluviatilis, Saunders, Man. Brit. B. p. 709 (1889).

Aduit Male in Breeding Plumage--General colour above sooty black, with a slight greenish gloss. 'The lower back and rump somewhat browner; wing-coverts and quills sooty brown; the secondaries with a good deal of white on them, sometimes confined to the base or to the inner web, but sometimes also occupying the whole of the latter, and even extending over the greater part of the outer web as well; tail rudimentary, consisting of a tuft of soft black feathers; crown of head and hind neck sooty-black like the back, but more distinctly washed with green; lores, region of the eye, and sides of face sootyblack, including the fore-part of the ear-coverts and cheeks; the 
hinder part of the latter, as well as the sides of the hinder crown and entire sides of the neck, deep chestnut, extending across the lower throat ; the chin and upper throat black, with an indication of a narrow blackish line of feathers down the chestnut portion of the throat ; fore-neck, breast, and sides of body black; the centre of the breast and abdomen blackish, but overlaid with a silvery white gloss; the lower flanks and a patch on each side of the rump, cinnamon rufous, many of the feathers tipped and black; axillaries and under wing-coverts, white; quills below ashy, whitish at the base ; bill black, with the tip yellowish, and the gape conspicuously greenish-yellow; hare spaces between the eye and the base of the bill blackish; legs and feet olive-green, paler on the webs; iris hazel. Total length, 8.5 inches ; culmen, $\mathrm{r}^{\circ} \circ$; wing, $4^{\circ} \mathrm{O}$; tail, $\mathrm{I} \cdot 2$; tarsus, $\mathrm{I}^{\cdot} 3$.

Adult Female in Breeding Plumage.-Resembles the male. Total length, 8.0 inches ; wing, 3.9 .

winter Plumage.-General colour above brown, the wings a little darker and more blackish, with the inner webs of the secondaries entirely white ; crown of head and neck dark brown; lores and ear-coverts light brown, with a whity-brown streak above the latter; sides of neck and the lower throat reddishbrown; cheeks and throat white; remainder of under surface of body silky white; the sides of the body rufous-brown, with dusky centres to the feathers.

Nestling.-General colour brown, with longitudual black and rufous streaks down the back, the head less distinctly striped; under surface of body dingy white, with black and rufous streaks on the throat and sides of neck.

Young in first winter.-Similar to the winter plumage of the adult, but generally with dusky streaks on the sides of the face.

Range in Great Britain.-The Little Grebe is found everywhere in localities suited to its habits, though it is rarer towards Scotland and the North generally. In Ireland, Mr. Ussher says, it is reported from every county, and it breeds commonly throughout the country, in suitable localities, on lakes, ponds, and rivers.

Range outside the British Islands.-The present species is an inhabitant of temperate Europe and Asia, and Japan. It does 
not range very far north in Europe, reaching to $62^{\circ}$ in Scandinavia, and it winters in the countries of the Mediterranean, as there are specimens in the British Museum from Marocco, Egypt, Halestine, and Asia Minor ; it doubtless also breeds in these southern habitats. In China it is represented by an allied form, Podicifes philippensis, which breeds in China, and winters in the south in the Philippines, being replaced in the Moluccas by Pedicipes tricolor. In India a white-quilled species takes its place, Podicipes altipennis, while the African Little Grebe, Podiciprs iapensis, is again distinct, and is represented in Madagascar by Podicipes pelselni. In Australia Podicipes gularis takes the place of $P$. fuviatilis, and in America the latter species is represented by Podicipes dominicus

Habits.-One of the most interesting accounts of the habits of the Little Grebe is that contributed by Mr. Bryan Hook to Seebohm's "History of British Birds":

"On the $25^{\text {th }}$ of March I found a Dabchick's nest on one of our small ponds about a foot from the water's edge, partly concealed by a tuft of heather on the bank above it. The pond was at the bottom of a field where a man was ploughing, and at the end of each furrow, as he passed the nest, the bird first carefully covered her eggs, then slipped into the water without the slightest splash, and remained concealed under the water amongst tise reeds close to the nest. A fortnight afterwards I found the old bird very reluctant to move, and when, at last, she did dive away, she left her eggs uncovered. Two days later I found the old bird sitting in the nest with two young, and all dived away on my approach, the young ones coming up about five yards from the shore, where they floated motionless. I did not see the young birds again until a fortnight later when I found them on the nest, wonderfully grown and able to dive about ${ }_{5} 5$ yards. Nearly a month later, on the 3 th of May, the two young birds were full grown, and whilst one of the parents took charge of them, the other sat upon five eggs in another nest in a similar situation on the other side of the pond. She was very restless, constantly getting off and on the nest. At length she found me out, and after carefully covering her eggs, slipped into the water behind the nest and 
remained there until I came up. Four days later some of the eggs were hatched. The birds slipped off the nest on my approach, but remained among the rushes close by. I waited a few minutes and then plainly heard the cheeping of a young bird, so I drove away the parent, and inmediately afterwards the young ones were floating a little away from the shore. The other parent bird had another young one further along the bank, so I ran towards it, but the young one scrambled under the wing of its parent, who dived away with it. The little one, however, came to the surface about ten yards from the shore. The young bird seemed able to dive unassisted about two yards. Old and young use their legs like a frog, horizontally, striking both at once, and bringing their feet together at the end of the stroke. I have seen the old ones diving in clear water some distance, but they did not use their wings. I spent the following day watching the Dabchicks through a telescope. One old bird was sitting on the nest whilst the other dived for food, which she brought at intervals of about two minutes. When she approached the nest the young birds put their heads out from under the parent's wing, and took the food the other parent brought. The moment her provision was disposed of, she was off for more, always diving from place to place. The morsel, when found, required a good deal of shaking before it was fit to be given to the young birds, and when prepared, the parent dived with it in her beak, appearing again at the edge of the nest. Whilst I was watching her the bird on the nest caught sight of me, carefully covered the eggs that were still unhatched, and slipped into the water. On going up to the nest I found two of the young birds amongst the rushes on the margin of the pond. I retired, and after watching a few minutes, saw the old bird suddenly appear at the side of the nest, after diving several times underneath it and swimming once or twice round it. After fully two minutes of this manceuvring it landed on the nest and procecded most carefully to remove the covering from the egrss and arrange it round the sides of the nest; then sitting upright for a moment and shaking out her feathers, she settled her breast upon the eggs. The other parent then came swimming up, and by its puffy appearance I think it had the youngsters under its wings. Seeing that all was going on well it probably deposited them 
in the nest, and then paddled gently off. An hour afterwards I found it very busy collecting weed to add to the nest; it made several journeys for the purpose, diving for the weed it used. After a time it brought some food, but finding the young ones would not take it, though it tried all round the nest, it ate it itself. On the next day both birds were hard at work adding to their nest; a strong breeze was blowing, and the waves would in a very short time have washed it away if it had not constantly been added to. On one occasion that the eggs were uncovered, I ran to the nest as fast as I could, but one of the birds came back and covered the eggs in a moment. Two eggs were still unhatched and one young bird was dead in the nest. This brood was evidently a failure; for eight days afterwards, on the $13^{\text {th }}$ of June, I found that a third nest had been built near an island about fifteen yards from the bank, and one of the birds was sitting upon it. Only on one other occasion have I ever seen the eggs left uncovered, which makes me think that the bird only covers her eggs when she is driven from the nest. I once disturbed a Dabchick and her young from the nest. They all dived away and disappeared in different directions, and when the young birds came up the parent swam alongside of them, and they scrambled under her wings, which she held up for the purpose. She then dived away, carrying with her the young birds, which might have been two or three days old."

I can quite endorse Mr. Seebohm's opinion of the worth of such observations as the above, especially in the case of such a bird as the Little Grebe, whose habits are most difficult to observe closely. I spent much time in studying the habits of the present species in my younger days. The birds were common in Hampshire at Avington, where my old friend, Sir Edward Shelley, used to invite me to visit him every spring. Not only were these Grebes abundant on the Itchen and its adjacent water-meadows, but several pairs bred on the lakes close to the house. They were always visible towards evening, and as the sun set over the waters, their curious trilling chatter was sure to be heard as they swam about near the mill-pool, or disported themselves over the big lake. In May, when the Ducks were nesting, and the surface of the water became covered with the growing reeds, the latter were the favourite 
refuge of the Grebes on the approach of danger, and their dark breeding-plumage effectually harmonised with their surroundings, as they dived out of danger and re-appeared amidst the shelter of the water-plants. The bright colour on the base of the bill often proved the easiest mode of detecting them.

As a rule the nest was placed on the fringe of the reed-beds skirting the lake, and the eggs, when first laid, were left exposed, or were but scantily covered. One nest which I found, with the full complement of eggs, was so thickly covered with wet water-weeds and rushes, that the eggs had to be felt for beneath it, and for some time I thought that the birds had deserted them, as they were always cold, and showed no signs of incubation, though day by day they became more and more discoloured. The constant presence of a pair of birds, however, in the vicinity of this nest, led me to believe that it was not deserted, and I more than once uncovered the eggs, only to find the wet covering replaced on each occasion. Intent on finding out whether the birds re-covered the eggs on leaving the nest, I approached it cautiously many times, but the Grebes appeared to have always detected my approach, and were placidly swimming in the middle of the lake, as if such a thing as a nest was the last thing in their minds. Once, however, I managed to come down upon it unperceived, when one of the parent birds flew away in a great fright, and no possible time was allowed for it to cover the eggs. They were, nevertheless, completely hidden, not by a few rushes, such as the bird could scrape together in a hurry, but by a dense covering of wetted and rotten weeds. I came to the conclusion that, in this instance at least, the hatching of the eggs would be left to the heat of the sun and the fermentation of the material of which the nest was composed. That this takes place in other countries has been affirmed by Mr. A. O. Hume and other excellent observers.

The time which the Little Grebe can spend beneath the surface is remarkable. I once drove one of these birds into a ditch about five feet wide, ending in a cul-de-sac, and felt sure that I should secure it. While standing on the bank, waiting for the bird to appear, I was astonished to see it swimming below me. Having evidently discovered that there was no outlet at the end of the ditch, it turned beneath the water and 
swam back to the river without reappearing till it was in the middle of the stream. The bird must have covered at least a hundred yards beneath the surface, and looked like a large frog more than a bird. When fishing on the Thames, I have more than once seen these birds swimming at a considerable depth in the clear water below me, and have directed their onward course with a punt-pole.

Nest.-A gruesome mass of wet reeds and water-plants, with sometimes, in shallow water, a foundation of water-weeds reaching to the bottom.

Eggs.-Four to six in number. Mr. Robert Read remarks : - "The eggs of birds taken on the Thames, when newly laid, are of a pure bluish-white, and become, later on, stained to a deep dirty yellow, but they are never of such a deep brown as the peat-stained eggs from some of the Scotch moorland lochs." Axis, I'35-I'55 inch; diam. 0.95-I'I.

THE THICK-BILLED GREBES. GENUS PODILYMBUS.

$$
\begin{gathered}
\text { Podilymbus, Less. Traité, i. p. } 595 \text { ( } 183 \text { I). } \\
\text { Type, } P \text {. podicipes (Linn.). }
\end{gathered}
$$

This American genus differs from the other Grebes which we have been considering, in having a remarkably stout bill, its depth being more than half of the length of the culmen.

1. THE PIED-BILlED GREBE. PODILYMBUS PODICIPES.

Colymbus podicipes, Linn. Syst. Nat. i. p. 223 ( 766 ). Podilymbus podiceps, Less.; Sharpe, P. Z. S. r 881, p. 734, Harting, Zool. I88 I, p. 334 ; Saunders, Manual, p. 7 Io, note (1889).

Adult Male.-General colour above blackish brown; the wingcoverts rather lighter brown than the back; quills light brown with dusky tips to the primaries, the secondaries white for the greater part of the inner web; innermost secondaries like the back; tail dark brown; crown of head and hind-neck blackishbrown, as also the lores; sides of face and ear-coverts ashygrey, with dusky centres to the feathers; cheeks white with dusky shaft-lines, extending down to the middle of the throat 
and skirting the black chin and centre of the throat; sides of neck and fore-neck ashy-brown; remainder of under surface white, thickly mottled with blackish centres to the feathers; sides of lower back and rump dark brown, with a slight reddish tinge, the feathers on the lower part of the abdomen darker grey; under wing-coverts and axillaries white:- "Bill milkwhite, crossed past the middle by a black band, the terminal portion more bluish; eyelids white; naked lores bluish; iris rich dark brown, with an outer ring of ochraceous white, and an inner thread-like ring of pure white ; tarsi and toes greenish slate-black on the outer, and plumbeous on the inner side" (R. Ridgreay). Total length, I $3^{\circ} \circ$ inches; culmen, I००; wing, $5 \cdot 35$; tail, $\mathrm{I}^{\circ} 5$; tarsus, $\mathrm{I}^{\circ} 5$.

Adult Female.-Similar to the male, but decidedly smaller. Total length, ro'o inches; wing, $4^{\circ} 7$.

winter Plumage--Brown above, with no black on the throat, which is white; otherwise as in the summer plumage, but the sides of the face are brown, and the lower throat, fore-neck, and sides of neck are rufous-brown; "bill, horn-colour, becoming blackish basally, and on the culmen; lower mandib!e more lilaceous, with a dusky lateral stripe; iris of three distinct colours, disposed in concentric rings, the first (around the pupil) clear milk-white, the next dark olive-brown, the outer pale ochraceous-brown, the dark ring reticulated into the lighter; tarsi and toes greenish-slate, the joints darker" (R. Ridgriay).

Range in Great Britain.-A specimen of this Grebe was exhibited by me at a meeting of the Zoological Society on the 2 Ist of June, I88I. It was brought to the British Museum by Mr. R. W. Munro, who stated that it had been killed at Radipole, near Weymouth, in January, I88I. I took much pains to assure myself of the genuineness of the occurrence, and as the bird was sold to Mr. Munro as a Little Grebe, there does not seem to have been any attempt at deception. Mr. J. E. Harting, however, throws doubt on it, as he says that the specimen "showed remains of longitudinal dark stripes on the neck, which are observable in the young of all the Grebes." Mr. Harting should have added that these dusky streaks are often retained by the young Grebes of 
the year till January and February, so that there is nothing extraordinary in the Weymouth specimen still exhibiting such marks in January, while the fact that it is a young bird renders it more probable that it had lost its way.

Range outside the British Islands.-The present species inhabits North America from Canada southwards, and extends to Brazil and Argentina, as well as to the West Indian Islands.

Habits.-Similar to those of other species of Grebe.

Nest.-A nest, found by Mr. N. B. Moore, in Florida, was "composed of broken stems of dog-fennel, matted together with a large portion of decayed and withered aquatic plants, presenting when found a wet, black, and soggy bed, to all appearances as uncomfortable a nest as ever fell to the lot of delicate and beautiful downy creatures such as the little ones were." (Baird, Brewer, and Ridgway, Water Birds N. Amer. ii. p. 442.$)$

Eggs.-Five in number. Bluish-white, with a chalky shellcovering, but becoming stained to a creamy-white or brown shade. Axis, $1 \cdot 7$ inch; diam., $1{ }^{\circ} 55$.

\section{THE RAILS. ORDER RALLIFORMES.}

In this order the palate is schizognathous, and the nasals holorhinal. The dorsal vertebræ are heterocœlous, and the posterior process of the ilium is sufficiently perforated to show a broad sacrum. The sternum has a single notch on each side of the posterior margin. The oil-gland is tufted and the after shaft is present on the contour feathers (cf. Sharpe, Cat. B, xxiii. p. I).

The Rails are mostly birds of an extraordinary slimness of body, and, as a rule, they are great skulkers, never venturing into the open unless driven out from their hiding places. This is especially true of the Water-Rails and Crakes, many of the tropical members of these groups being almost, or quite, incapable of flight. 


\section{THE RAILS AND WATER-HENS. FAMILY RALLID $A$.}

The characters of this family are the same as those of the order, and the Rallida are divisible into two sub-families, the Rallince and the Coots or Fulicina.

The latter birds are recognised by their lobed toes, which somewhat resemble those of Grebes, and it is for that reason, and for other characters also, that I place the Ralliformes in close proximity to the Podicipedidiformes.

\section{THE RAILS. SUB-FAMII,Y RALLINA.}

In arranging the Rails in the twenty-third volume of the "Catalogue of Birds," I found it impossible to separate them into more than the two sub-families above-mentioned, for the close connection between Rails, Crakes, and Water-hens does not allow of any line being drawn between them, and the latter approach the Coots in appearance and habits, but have not the lobed toes, which seem to constitute a character of importance.

\section{THE TRUE RAILS. GENUS RALLUS. \\ Rallus, Linn. Syst. Nat. i. p. 26 I ( 7 66). \\ Type, $R$. aquaticus, Linn.}

In this genus the bill is very long and narrow, with a deep and well-marked nasal groove, the culmen generally exceeding the length of the midule toe and claw, or at least equal to it in fully grown birds. The tarsus is shorter than the middle toe and claw. The nasal aperture is situated nearer to the feathers at the base of the bill than to the anterior end of the nasal groove.

\section{THE WATER-RAIL. RAllus AQUaticus.}

Rallus aquaticus, Linn. Syst. Nat. i. p. 262 ( 1766 ); Macgill. Brit. B. iv. p. 52 I (1852); Dresser, B. Eur. vii. p. 257 , pl. 495 (1878) ; B. O. U. List Brit. B. p. I46 (1883); Saunders, ed. Yarrell's Brit. B. iii. p. I59 (1883); Seebohm. Hist. Brit. B. ii. p. $55^{2}$ (1884); Saunders, 
己

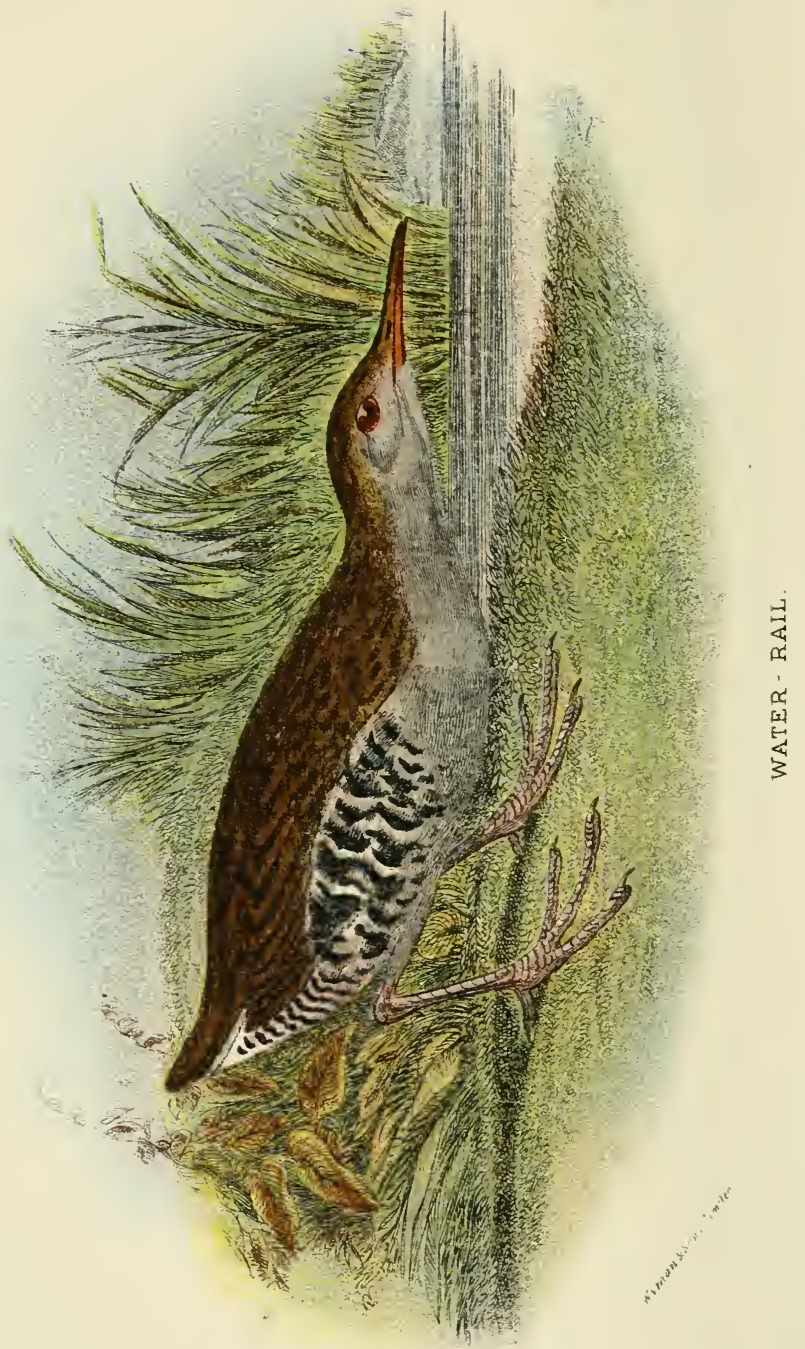


Man. Brit. B. p. 50 I (1889); Lilford, Col. Fig. Brit. B. part xx. (1891); Sharpe, Cat. B. Brit. Mus. xxiii. p. 20 (1894).

\section{(Plate CXVI.)}

Adult Male in summer Plumage.-General colour above olive. hrown, broadly streaked with black, the feathers being all longitudinally centred with black, the rump more uniform olive-brown; the upper tail-coverts centred with black like the back; wing-coverts and inner secondaries like the back; the outer coverts, bastard-wing, primary-coverts, and wing blackishbrown, quite uniform, or slightly washed with olive externally; the first primary pale brown along the outer web; tail-feathers blackish, externally olive-brown; crown of head and hind-neck like the back, more minutely streaked with black; a broad eyebrow, sides of face, and under surface of body dark slaty grey, with a slight dusky shade on the lores and region of the eye; throat and fore-neck rather lighter grey than the breast; sides of upper breast olive-brown, centred with black like the back; flanks and sides of vent black, transversely barred with white; lower abdomen and vent isabelline bilf; under tailcoverts black, barred with white and tipped with isabelline buff, the lateral under tail-coverts white; under wing-coverts and axillaries black, barred and edged with white; quills ashyblackish below. Total length, I I inches; culmen, I 7 ; wing, 4.9 ; tail, $2 \cdot 3$; tarsus, $1 \cdot 5$.

Adult Female.--Similar to the male, but rather smaller; bill above nostril very dark brown, below nostril and lower mandible orange-red; feet light fleshy brown; iris orange-red. Total length, 9.5 inches; wing, 4.2.

Adult in winter Plumage.-Similar to the summer plumage, but decidedly browner; the under parts freckled with light brown edges to the feathers, each margin preceded by a dusky sub-terminal line; the lower flanks and thighs strongly washed with fulvous brown; the outer upper wing coverts with zig-zag white bars; throat whitish.

Young.-Similar to the winter plumage of the adults, but with a whiter throat, and the whole of the centre of the breast and abdomen whitish, slightly washed with brown, and with 
obscure dusky bars; outer wing-coverts with narrow white bars.

Nestling.-Covered with black down.

Range in Great Britain.-The Water-Rail nests in nearly every county of England, Wales, and Scotland, where suitable localities exist. It is rarer in the latter kingdom, and breeds sparsely, but Mr. Robert Read has recorded its eggs from Possil Marsh, near Glas ow. In Ireland, Mr. Ussher says that it is reported to nest in every county. A considerable migration southward appears to take place in winter; but the species has been known to stay during the latter season in the Shetlands.

Range outside the British Islands.-The present species is resident and breeds in most of the countries of Europe, excepting the extreme northern parts, being resident in Norway near Bergen, and ranging nearly up to the Arctic circle, while it has also occurred on Jan-Mayen, and is believed to be resident in Iceland. Its eastward range extends to Turkestan and Afghanistan, and it visits North-western India in the winter, occurring as far east as the Nepal Terai. In Eastern Siberia, Japan, and China, $R$. indicus takes its place, and this species migrates south, visiting Southern China, and the Burmese Provinces, and extending west to the district of Calcutta and to Oudh.

Habits.-The Water-Rail, like most of its relations, is a very shy bird, and one whose habits are most difficult to study in consequence. It takes flight most unwillingly, and trusts to its legs for safety. Even in the thickest of brakes it can twist and turn with great rapidity, while its peculiarly compressed and slender body enables it to thread its way through the grass and rushes at a high rate of speed. One which I shot at Avington, in November, gave me a lot of trouble to secure. Our party was returning from duck-shooting in the water meadows, when I saw the retriever running along the side of a hedge-row, with a deep ditch of water on the side nearest to me. I crept up, thinking that he was after a wounded Duck, but for some time I could see nothing of his quarry. At last I could make out 
something like a rat darting out from under the roots of a bush, and apparently making for the river. When the dog approached its hiding-place again, the Rail, as I now perceived it to be, instead of taking to flight and putting the Itchen between it and its pursuer, deliberately doubled, and running past the dog, which had an insecure foothold on the sloping bank, scudded some fifty yards back along the latter, and hid up. The retriever retraced his steps, and again drove the Rail towards the river, but the bird repeated its doubling manœuvre, and the dog had to resume the chase again from the starting point. At last the Rail took flight, and flew across the river with reluctance, with its legs hanging down, when I shot it. During the whole of the chase this bird uttered no sound; but the WaterRail has a note, which Naumann describes as a clear, shrill, but melodious kreek, uttered principally during the evening when preparing to migrate. During the pairing season, at evening time, it utters a liquid wheet, not unlike that of the Nuthach. The food of the bird consists of worms, insects, snails, and gnats, and it also eats the tender shoots of aquatic plants, or the seeds of reeds and sedge, according to Seebohm. Mr. Howard Saunders says that "during the breeding season Water-Rails are very noisy, uttering a loud groaning cro-o-o-an, called 'sharming ' in Norfolk."

Nest.-A nest found by Seebohm and Mr. Howard Saunders in the Norfolk Broads is described as being "admirably concealed. It was about a foot from the ground, but had a solid foundation under it, formed by the roots of the clump of rushes, in the midst of which it was built. It was carefully made of flat sedge and the flat leaves of the reed, lined with dry broken pieces of round slender reeds."

Eggs.-Five to seven in number, but sometimes as many as nine or eleven. Ground-colour creamy or pinkish-stone, with a few spots of rufous distributed over the egg, or clustering towards the larger end. The egg is double-spotted, the underlying spots being lilac-grey, and nearly as distinct as the overlying ones. As a rule the rufous spots are small, but occasionally they are large and form blotches towards the big end of the egg. Axis, $\mathbf{I}^{\cdot} 4-\mathrm{I}^{\circ} 5$ inch; diam., I'O-I.05. 


\section{THE LAND-RAILS. GENUS CREX.}

Crex, Bechstein, Orn. Taschenb. p. 336 (I 802 ).

Type, Crex crex (Linn.).

All the Crakes have much shorter and stouter bills than the true Rails, the culmen in the genus Crex being less than the length of the inner toe. The tarsus is about equal in length to the middle toe and claw, and there is no frontal snield as in the Water-Hens.

Only one species of true Crake is known, viz., the CornCrake or Land-Rail described below.

\section{THE LAND-RAIL. CREX CREX.}

Rallus crex, Linn. Syst. Nat. i. p. 26 I ( 766 ).

Crex pratensis, Bechst.; Macgill. Brit. B. iv. p. 527 (1852); Dresser, B. Eur. vii. p. 29I, pl. 499 (I878); B. O. U. List. Brit. B. p. I 49 (1883); Saunders, ed. Yarrell's Brit. B. iii. p. I 57 (I883); Seebohm, Hist. Brit. B. ii. p. 535 (1884); Saunders, Man. Brit. B. p. 493 (1889). Crex crex, Sharpe, Cat. B. Brit. xxiii. p. 82 (1894).

(Plate CXVII.)

Adult Male in Summer Plumage.-General colour above brown, mottled with black centres to the feathers, which have more or less of an ashy shade on their margins; scapulars like the back, with broad black centres; wing-coverts uniform bright chestnut; bastard-wing, primary-coverts and quills chestnut brown, the first primary externally isabelline buff, the inner secondaries like the back, with black centres, and indistinguishable from the scapulars; tailfeathers light reddish-brown, centred with black; crown of head fulvous brown, mottled with black centres to the feathers, the two colours arranged in streaks; hind-neck and sides of neck fulvous brown, with smaller blackish-brown spots; lores and feathers below the eye, as well as a band along the upper earcoverts to the sides of the neck sandy-buff; above the eye a band of ashy-grey, widening towards the sides of the nape; ear-coverts, cheeks, lower throat, fore-neck, and chest ashygrey; the chin and upper throat isabelline; breast and 



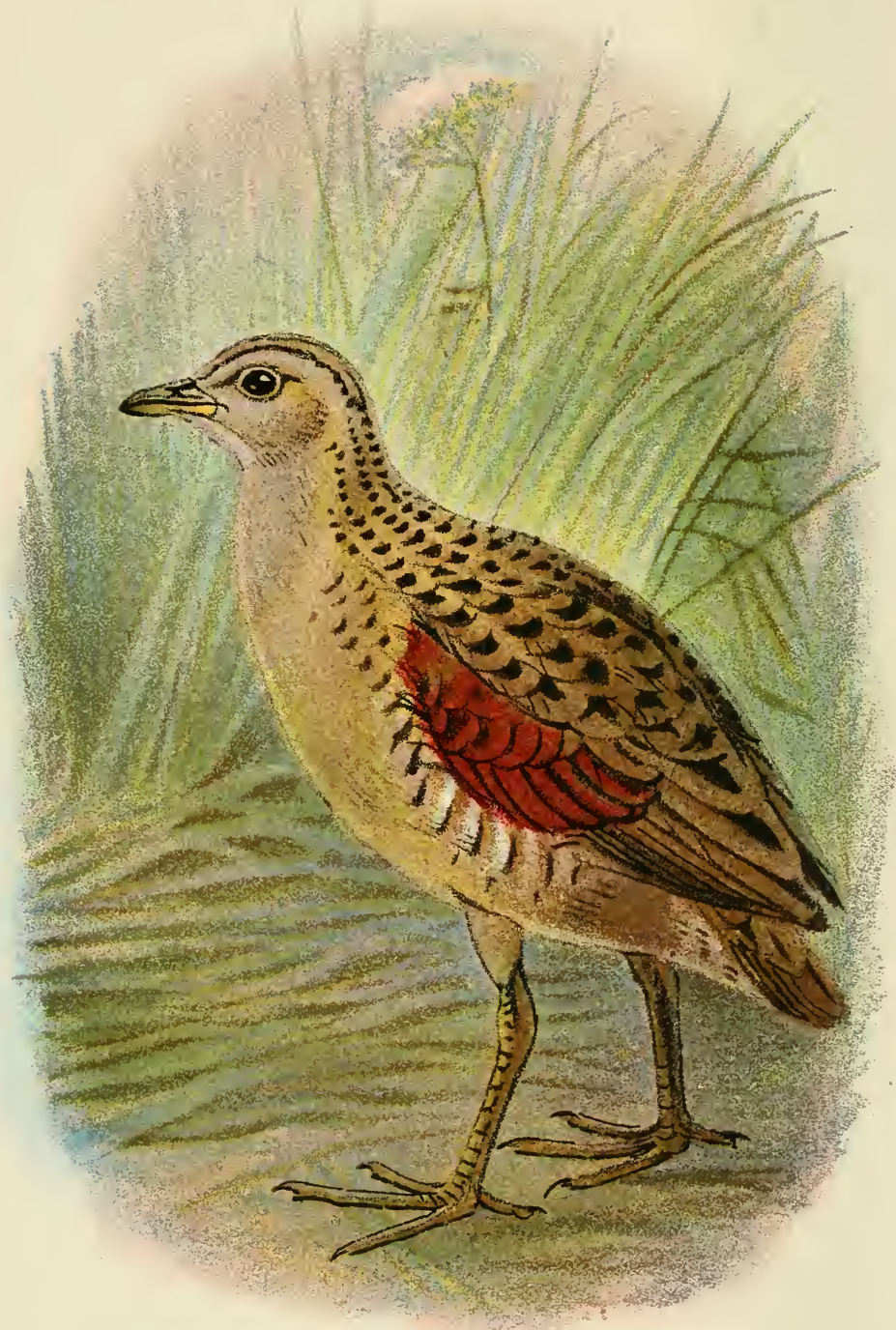

LAND RAIL. 
abdomen isabelline, as well as the upper tail-coverts; sides of upper breast brown, with a few white bars; flanks sandy. rufous or rufous-brown, the feathers tipped and barred with isabelline or whitish; sides of vent barred with darker brown, thighs sandy-rufous; shorter under tail-coverts barred with rufous and brown; under wing-coverts and axillaries bright chestnut; quills below brown, rufescent along the inner edge; bill, feet, and claws pale brown; iris hazel. 'Total length, Io inches; culmen, 0.85 ; wing, 5.6 ; tail, $\mathrm{I}^{\circ} 9$; tarsus, $\mathrm{I}^{\circ} 45$.

Adult Female.-Similar to the male, and having the same grey on the eyebrow, face, and breast. Total length, 9 inches; wing, $5^{\cdot} 2$.

Aduit in Winter Plumage.-As in summer, but instead of the grey on the eyebrow, sides of face, and breast, these parts are all ochreous brown, and the sides of the body are decidedly more rufescent, with distinct and broad bars of black on the flanks and under tail-coverts; the wing-coverts also have distinct whitish bars, particularly on the greater series, where these bars have blackish or dusky margins.

Young after First Moult. - Similar to the winter plumage of the adults, and lacking the grey on the face and breast, and having the sides of the body nearly uniform tawny, with a few dusky bars and whitish tips to the feathers.

\section{Nestling.-Covered with black down.}

Range in Great Britain.-This Rail is found throughout the British Islands from the south to the north, including the Hebrides, the Orkneys, and Shetlands. In Ireland, Mr. Ussher says it breeds commonly in every part except the mountains, nesting even in some of the islands, such as Innishbofin. In the home counties of England, however, there is a decided decrease in the number of Land-Rails every summer, which it is difficult to account for. At Cookham, for instance, in the Thames valley, the bird seldom visits us, though the hay-fields are the same and its haunts absolutely unchanged from the days when it was always present, thirty years ago. I am speaking of my brother-in-law's estate, in which no change has taken place. In the neighbourhood of London, no doubt, the vast increase of building must account 
for the driving away of this shy bird from some of its old haunts.

Range outside the British Islands.-The Land-Rail is distributed over the greater part of Europe and Asia as far east as the Valley of the Yenesei, and that of the Lena, breeding also in Western Turkestan. On migration it passes through the countries of Southern Europe, but Mr. Saunders believes that it does not breed south of the line of the Pyrenees. Its winter quarters are in Africa, and at this season of the year it also wanders to Arabia and the shores of the Persian Gulf. The Land-Rail has also been met with in Greenland and the Eastern United States, and in the Bermudas.

Habits.-The Land-Rail or Corn-Crake is a familiar inhabitant of our pasture-lands in summer, where its grating and monotonous creak-creak is heard, especially towards evening, and long after darkness has set in. Its cry is distinctly ventriloquial, and Mr. Howard Saunders considers that this is due "to the marvellous rapidity with which it sneaks, unperceived, from one spot to another." I have not myself observed this; but, on the contrary, I believe that, like the notes of the Creeper or the Grasshopper Warbler, the utterance of the Corn-Crake's note has that ventriloquial power that makes its cry sound far or near. I remember, on one occasion, making my way into one of our own fields of high grass at Cookham in search of one of these birds at night, and when within ten yards of the Crake, its note sounded from all points of the compass around me ; but I stopped still, refusing to be deluded by its ventriloquism, until I crept to the spot whence I was sure that the sounds proceeded, and at last I managed to approach so close above it that I almost succeeded in catching it before it scented danger and scuttled away. My old friend Briggs, the Cookham naturalist, who first taught me to skin birds, and with whom Mr. Howard Saunders and myself have had many a ramble, used to pride himself on being able to track Land-Rails in the grass, and I remember on one occasinn walking with him in the meadows opposite the Cliefden Woods, when we heard the creak of one of these Rails close to us in a hay-field. He not only walked straight to where the bird was, but as it flew up, he threw his walking-stick at it and 
knocked it down close to the river's edge, when the bird took to the water and swam right across to the other side of the 'Thames.

The food of the Corn-Crake is varied, and consists of worms, slugs, snails, small lizards, and also of seeds and plants.

Nest.-A simple structure of dry grass and plants, placed on the ground.

Eggs.-From seven to ten in number. Ground-colour varying from stone grey to greenish-white or buffish clay-colour, with numerous dots and spots of rufous distributed over the egg, the underlying grey spots very distinct and equally distributed. Sometimes the rufous markings collect round the large end of the egg and form a blotch; but in many eggs, particularly of the stone-coloured type, the spots are more scattered and universally distributed over the surface. Axis, $I^{\cdot} 4-I^{\circ} 55$ inch; diam., I'O-I'I.

\section{THE LITTLE CRAKES. GENUS ZAPORNIA.}

Zapornia, Leach, Syst. Cat. Mamm. \& Birds, Brit. Mus. p. 34 (1816).

$$
\text { Type, Z. parva (Scop.). }
$$

The small Crakes of the genera Zafornia and Porzana differ from the true Crakes (Crex) in their long middle toe, which, with the claw, exceeds the tarsus in length. The sexes in the genus Zapornia differ in colour, and the secondaries are conspicuously shorter than the primaries, falling short of them by as much as the length of the inner toe and claw, so that the wing is decidedly pointed in shape for a Crake.

\section{THE LITTLE CRAKE. ZAPORNIA PARVA.}

Rallus parvus, Scop. Ann. i. p. 108 (1769). Crex pusilla (nec Pall.), Macgill. Brit. B. iv. p. $5+1$ ( 1852$)$. Por:ana par'a, Dresser, B. Eur. vii. p. 283 , pl. 498 (1878); B. O. U. List Brit. B. p. $148(1883)$; Saunders, ed. Yarrell's 13rit. B. iii. p. 148 (1883); id. Man. Brit. B. p. 497 (I 889). 
Crex parva, Seebohm, Hist. Brit. B. ii. p. 457 (I884). Zapornia paria, Sharpe, Cat. B. Brit. Mus. xxiii. p. 89 (I 894).

Adult Male in Breeding Plumage.-General colour above ochreous brown, varied with black centres to the feathers and a few white spots; the scapulars and innermost secondaries ochreous brown with black centres, the latter pale ochreous along their inner webs, forming a longitudinal band on each side of the back; the rest of the wing-coverts nearly uniform brown; bastard-wing, primary-coverts, and quills sepia-brown; lower back, rump, and upper tail-coverts darker and with more black than the rest of the back, the feathers being black edged with brown; tail-feathers also black edged with brown; hinder crown uniform reddish-brown, like the hind-neck ; forehead, a broad eyebrow, sides of face, and entire under surface of body light slaty-grey; sides of breast ochreous brown, like the sides of the neck; flanks almost entirely uniform, excepting for a few white bars, and dusky on the lower thighs and vent; under tail-coverts white, washed with ochreous and crossed with blackish bars; under wing-coverts and axillaries uniform brown, like the quill-lining; bill green tinged with red at the base; legs and feet green; iris deep sarmine. 'Total length, 7 inches; culmen, 0.7 ; wing, 4 ; tail, 2 ; tarsus, $\mathrm{I}^{\cdot}{ }_{5} 5$; middle toe and claw, $\mathrm{I}^{\cdot} 6$.

Adult Female.-Similar to the male on the upper surface, but a little more olive, the brown colour of the head extending in a narrow line to the base of the bill; lores hoary-grey; sides of face and a broad eyebrow grey; a faint tinge of brown on the ear-coverts; cheeks and throat white; remainder of under surface, from the fore-neck downwards, pale vinaceous isabelline; thighs clear ashy, as also the lower flanks, which have dusky bars and white edges to the feathers; vent and under tail-coverts barred with black and white, the lattcr tinged with ochreous buff. Total length, 7 inches; wing, 4.05 .

Young.-Similar in general to the adult female, but having the scapulars mottled with white bars; under-surface of body entirely white, as also the sides of face and eyebrow ; the breast more or less varied with the remains of dusky edgings to the feathers; the thighs distinctly banded with brown and 
white; the greater coverts, primary-coverts, and quills with more or less distinct white spots at the tips.

Nestling.- " Covered with black down with a greenish gloss; legs bluish-grey" (IV. Eagle Clarke).

Range in Great Britain.-A spring and autumn visitor to our islands. No authentic instance of its having bred in England has been noted. Though it has been recorded from many counties, and especially from Norfolk, in Scotland and in Ireland the species has occurred but once.

Range outside the British Islands.-The Little Crake breeds throughout Central Europe and Russia, and is believed to have nested in Southern Sweden. In Italy it also breeds, but in other parts of the Mediterranean it is only known as a migrant, though resident again in Algeria. Its eastern range extends to Central Asia and Afghanistan, and it winters in North-Western India and in Equatorial Africa.

Habits.-Mr. A. O. Hume thus describes the habits of the Little Crake in Sind:- "I never flushed these birds out of sedge or reed, but found them everywhere running about orer the lotus and water-lily leaves, or swimming about from leaf to leaf, and exhibiting far less timidity than Baillon's Crake. Like the latter, they look when in the water exactly like tiny Water-hens, jerking their tails and nodding their heads exactly like the latter. One thing I noticed in this species which I never observed in either of the others-I saw one bird voluntarily diving several times, apparently in search of food. The others will dive when a shot is suddenly fired near them, or when they are wounded, but this bird was deliberately diving for its own amusement. When pressed, they rise more steadily and fly more strongly than Baillon's Crake, taking refuge in the thickets of tamarisk that fringe the broads, and are studded about most of them as islands. The food of this species seems to consist far more exclusively of insects than that of Baillon's Crake. In more than a dozen specimens which I examined, the stomachs contained water-bugs and beetles, small insects of all kinds, and larvæ of various, and to me quite unknown, species, with here and there a few small black seeds and a trace of vegetable matter. Of course, as is 
the case with Baillon's Crake, there were a good many minute pebbles or fragments of quartz, coarse sand in fact, mixed with the food, in the triturition of which it no doubt forms an important part."

Nest.-Mr. Eagle Clarke found the nest of this species in Slavonia, in an extensive and particularly secluded shallow marsh near the village of Obrez. The surface of the marsh was clothed with sallow-brakes, reed-beds, and areas covered with tussocks of sedge. The nest, containing seven eggs, was placed on the side, not in the centre, of one of these tussocks of medium size. It was merely a depression, amply lined with short broad pieces of withered reed blades, and was about six inches above the surface of the water, which was here about eighteen inches deep.

Eggs.--Seven or eight in number. Ground-colour pale olive, flecked with brown; oval in shape. Axis, $I \cdot I$ inch; diam., 0.85 .

THE SPOTTED CRAKES. GENUS PORZANA.

$$
\begin{gathered}
\text { Porzana, Vieillot, Analyse, p. 6I (1816). } \\
\text { Type, P.porzana (Linn.). }
\end{gathered}
$$

The genus Porzana resembles Zapornia in having the tarsus shorter than the middle toe and claw, but the shape of the wings is different. The secondary quills fall short of the primaries by as much as the length of the hind toe and claw, and they are consequently more rounded than in Zapornia. The sexes are alike in plumage.

\section{THE SPOTTED CRAKE. PORZANA PORZANA.}

Rallus porzana, Linn. Syst. Nat. i. p. 262 (1766).

Crex porzana, Macgill. Brit. B. iv. p. 535 (1852); Seebohm, Hist. Brit. B. ii. p. 540 (I884).

Porzana maruetta, Bp.; Dresser, B. Eur. vii. p. 267 , pl. 496 ( 1878$)$; B. O. U. List. Brit. B. p. 147 (1883); Saunders, ed. Yarrell's Brit. B. iii. p. I43 (I884); id. Man. Brit. B. p. 495 (I889).

Porzana porzana, Sharpe, Cat. B. Brit. Mus. xxiii. p. 93 ( 1894$)$. 



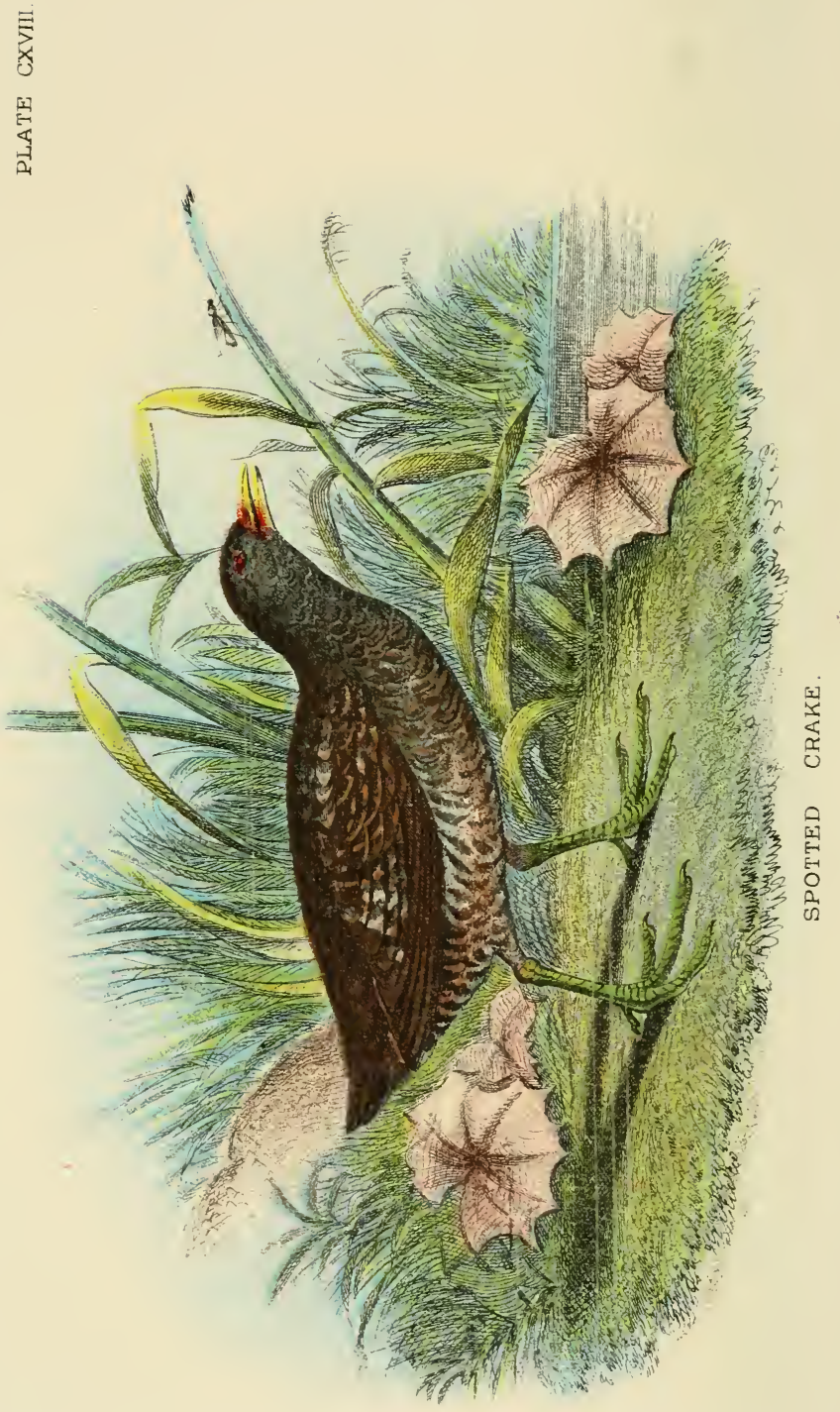


Adult Male in Winter Plumage-General colour above olivebrown, mottled with white and black markings, the white being distributed in the form of lateral spots on the dorsal feathers, and on the scapulars and wing-coverts in the form of arrow-head spots or bars, which are margined with black; all the feathers of the upper surface with more or less concealed black centres; wing-coverts rather lighter brown than the back, the white spots somewhat less plentifully distributed, excepting on the greater series and innermost secondaries, where the white bars with their accompanying black lines are very distinct and somewhat zig-zag in character on the latter; bastard-wing, primary-coverts, and quills sepia-brown, externally whitish-brown, with a white edging to the first primary and outer feathers of the bastard-wing; the innermost secondaries paler and more sandy-brown along their inner webs; lower back black, with a few small white markings; rump and upper tail-coverts olive-brown, centred with black, the lateral feathers rather conspicuously barred and edged with white; tail-feathers dark brown, externally lighter brown; crown of head olive-brown, the feathers spotted with black like the back; forehead and eyebrow slaty-grey, the latter profusely dotted with white; a narrow line at the base of the forehead and a loral spot black, extending below the eye and on the fore part of the cheeks; above the lores a faintly indicated spot of white; cheeks and throat slaty-grey, dotted with white; ear-coverts uniform brown, extending on to the sides of the neck; neck, fore-neck, breast, and sides of body everywhere spotted with white, which takes the form of crossbars on the sides of the body, each white bar skirted by a narrow blackish bar above and below; the chest and upper breast shaded with ashy; lower breast and abdomen white, shading off into sandy-buff on the vent and under tail-coverts; lesser under wing-coverts and edge of wing conspicuously white; remainder of under wing-coverts and axillaries dusky brown barred with white, resembling the flanks; quills dusky below; bill yellow, orange-red at base, dusky on the culmen and at the tip ; legs and feet green; iris brown. Total length, 9 inches; culmen, 0.85 ; wing, 4.85 ; tail, $I^{\circ} 7$; tarsus, $I^{\circ} 3$; middle toe and claw, I.7.

Adult Female.-Differs from the male in having the sides of 
the face more mottled, the breast and throat apparently never so uniform grey as in the male.

Adult in Summer Plumage.-Very similar to the winter plumage, but not so distinctly varied with white above ; the white dots also absent for the most part on the eyebrow, sides of neck, throat, and breast, which are almost uniformly grey, the latter slightly washed with brown.

Young.-Easily distinguished from the adults by its white throat and more profusely spotted appearance. The streaks on the back are also very distinct, as a rule. The adult plumage appears to me to be gained without a moult, the grey colour being gradually assumed as the spring advances; but I have not had a sufficient series to determine accurately the various phases through which the species passes. The young bird has the brown of the head continued to the base of the forehead.

Range in Great Britain.-The Spotted Crake, like so many marsh-haunting birds, is rarer than it used to be before the draining of the fen-lands. It is a summer visitor, nesting in several of the southern counties of England, as well as in the eastern counties as far north as Durham and Northumberland. On the east side of Scotland, says Mr. Saunders, it has nested as far north as Elgin, while on migration it has occurred in the Orkneys, and twice in the Shetlands (in October) ; on the west it has bred in Dumbartonshire, but has not yet been recorded north of the Clyde. Mr. Ussher states that three eggs of this species taken in Roscommon are in the Science and Art Museum in Dublin ; and he says that, "though no other instance of the nest having been taken in Ireland has been recorded, the Spotted Crake probably breeds occasionally, for Mr. Barton met with the species in Louth, in August. A pair were shot in Queen's County by Mr. T. Trench, in August, I88o, and another pair in Fermanagh, by Mr. George Husbands, in the summer or early autumn of 1890 . Thompson noted a young bird obtained in August by Mr. Chute, in Kerry, which exhibited remains of down."

Range outside the British Islaads.- The present species nests throughout the greater part of Europe, up to about $65^{\circ} \mathrm{N}$. Lat. 
in Scandinavia. Eastwards it ranges as far as Yarkand and Gilgit in summer, and in winter it is found throughout the southern border of the Mediterranean, as far as Abyssinia, as well as in the Persian Gulf, and Northern India, from Sind to Oudh and Calcutta. It has twice occurred in Greenland.

Habits.-Like all Rails, the Spotted Crake is a bird of the most skulking habits, and on migration it will sometimes be found in little reed-covered pools, from which it may sometimes be flushed by a dog, when its presence is least suspected. In such manner I have procured a few specimens in the Thames valley, near Cookham. Seebohm obtained a large number of eggs of this bird at Valkensvaard, in Holland. He writes as follows:- "The habits of the Spotted Crake are precisely the same as those of the Water-Rail, to which bird it otherwise bears so close a resemblance that it is difficult to believe that the two birds ought to be placed in different genera. They are both equally shy and skulking; they frequent the same fenny and marshy districts ; one is as unsociable as the other, and as unwilling to take wing; their flight is the same-a heavy, laboured, straight fiight through the air, with rapid beats of the broad rounded wings. The note during the breeding season is the same liquid whit, though that of the smaller bird is not so loud ; and the position of the nest and the materials of which it is composed are so similar that a description of one reads like a copy of that of the other."

Nest.-Large for the size of the bird, built in clumps of rushes or amongst reeds. Those found by Seebohm in Holland stood nearly a foot above the level of the water, and were composed of flat leaves of the reed, sedge, and other water-plants, and generally, when built in the reeds, had a foundation of flat broken rushes.

Eggs.-From eight to twelve in number. Ground-colour olive or clay-brown to reddish clay-colour, or chocolate. The spots are light or dark reddish-brown, and are distributed over the egg; the underlying grey spots mixed up with the darker ones, and sometimes quite as distinct as the latter. In rare instances the reddish spots are confluent, and form blotches. Axis, I*35-I’5 inch; diam., 0.95-I'05. 
1I. THE CAROLINA CRAKE. PORZANA CAROLINA.

Rallus carolina, Linn. Syst. Nat. i. p. 363 ( 1766 ).

Porzana carolina, B. O. U. List. Brit. B. p. I47 ( 1883 ); Saunders, Manual Brit. B. p. 496, note (1889); Sharpe,

Cat. B. Brit. Mus. xxiii. p. 97 ( 1894$)$. Crex carolina, Seebohm, Hist. Brit. B. ii. p. 54I (I884).

Adult Male.-General colour above olivaceous brown, varied with black centres and white margins to the feathers; the lower back and rump darker, the black centres to the feathers being more pronounced; wing-coverts for the most part uniform olivaceous brown, with white spots and freckles on the greater series ; bastard-wing, primary-coverts, and quills, dusky-brown, externally olivaceous brown, the bastard-wing feathers and outer primary edged with white; the innermost secondaries centred with black and edged with white like the back; tail-feathers olivaceous brown, with blackish centres; crown of head and neck more rufous brown than the back, and more uniform; forehead and centre of crown black, as well as the lores, fore part of cheeks, and centre of throat and fore-neck; a narrow eyebrow, sides of face, sides of neck, and chest ashy-grey; breast white, the lower flanks barred with black; the sides of the body brown, barred with white, each white bar with a narrow border-line of black; thighs brown; under tail-coverts white, the vent tinged with fulvous; under wing-coverts brown, edged with white like the edge of the wing; axillaries brown, distinctly barred with white; bill yellow at base, dusky towards the end ; feet yellowish-green; claws light brown; iris bright chestnut. Total length, 8.0 inches; culmen, $0^{\circ} 9$; wing, 4.3; tail, $\mathrm{I} \cdot 9$; tarsus, $\mathrm{I} .45$; middle toe and claw, $\mathrm{I}^{\circ} 75$.

Adult Female.-Similar to the male in colour. Total length, $8 \cdot 0$ inches; wing, 4.25 .

Young. - Upper surface resembling that of the adult, but the under surface for the most part white; the lower throat and fore-neck, sandy-buff; the under tail-coverts light tawny buff; sides of the breast brown, and the flanks black, both barred across with white; lores and sides of face ashy-brown; a supra-loral streak, eyebrow, and cheeks sandy buff. 
The adult plumage is gained in the first winter, but the grey feathers of the neck still retain brownish margins.

Characters.-The Carolina Crake differs from our Spotted Crake in having the fore part of the cheeks, lores, and centre of the throat, black; the inner web of the innermost secondaries is like the rest of the quills, and is merely fringed with white. In $P$. porzana it is light fulvous brown.

Range in Great Britain.-A single specimen of this North American species has been shot near Newbury in Berkshire; it was exhibited by Professor Newton to a meeting of the Zoological Society on the I 4 th of February, I865.

Range outside the British Islands. - The Carolina Crake is found in summer throughout temperate North America, and it winters in Central America, the IVest Indies, and the Northern provinces of South America.

Habits.-Dr. Brewer publishes the following interesting note * on the habits of the present species in the "Water-Birds of North America":-

"Early in August, when the reeds have attai ad their full growth, the 'Sora Rail' resorts to them in great numbers to feed on the seeds, of which it is very fond. This reed (the Zizania clavulosa of Michaux) grows up from the soft muddy shores of the tide-water, where the surface is alternately bare and covered with four or five feet of water, and attains a height of ten feet, covering tracts of many acres in extent, the stalks growing so closely together that a boat, excepting at high water, can hardly make its way through them. The seed of this plant is long and slender, white in colour, sweet to the taste and very nutritious. When the reeds are in fruit, the Rails, in great numbers, take possession of them. At this season, a person walking along the banks of the river may hear their cries in every direction. If a stone is thrown among the reeds, there is a general outcry, and a reiterated $k u k-k u k-k u k$, like the scream of a Guinea Fowl. Any sudden noise produces the same effect. None of the birds, however, can be seen except at high water; and when the tide is low, they keep secreted,

* Taken from Doughty's "Cabinet of Natural History." 
and a man may walk where there are hundreds of them without seeing a single one."

Nest.-Usually a mere collection of decayed moss and coarse grass, loosely aggregated, and not admitting of removal as a nest. (Brewer.)

Eggs. - From seven to twelve or even fourteen in number. Clay-colour, with scattered reddish spots and grey underlying ones. Axis, $\mathbf{I}^{\cdot 2} \mathbf{2} \cdot \mathbf{3} 3$ inches; diam., 0.95.

\section{BAILLON'S CRAKE. PORZANA INTERMEDIA.}

Rallus intermedius, Hermann, Obs. Zool. i. p. I98 (I804). Crex bailloni, Boie; Macgill. Brit. B. iv. p. 539 (1852); Seebohm, Hist. Brit. B. ii. p. 543 (I884); Lilford, Col. Fig. Brit. B. part xx. (I89 I).

Porzana bailloni, Dresser, B. Eur. vii. p. 275, pl. 497 (1878);

B. O. U. List Brit. B. p. 143 ( 1883 ); Saunders, ed. Yarrell's Brit. B. iii. p. $154\left(188_{3}\right)$; id. Man. Brit. B. p. 499 (I 889).

Porzana intermedia, Sharpe, Cat. B. Brit. Mus. xxiii. p. 103 (1894).

Aduit Male.-General colour above dark ochreous-brown, with black centres to nearly all the feathers, which are marked with white spots and freckled with black; lower back black, freckled with white, but only slightly washed with ochreousbrown; upper tail-coverts ochreous-brown with black centres; lesser and median wing-coverts uniform ochreous-brown, like the back, the greater series with blackish centres and white frecklings; the innermost secondaries like the back, with broad black centres, the inner webs pale ochreous-brown, thereby forming a broad longitudinal band on each side of the back; bastard-wing, primary-coverts, and quills sepiabrown, the edges of the bastard-wing feathers and the first primary white; tail-feathers blackish, edged with dark ochreous-brown; centre of crown and hind-neck dark ochreous or reddish-brown, only feebly streaked with black centres to the feathers; forehead and a broad eyebrow, as well as the entire sides of face, throat, and breast, clear slatygrey; abdomen, flanks, and thighs blackish, mottled with white bars; under tail-coverts deep black, barred with white; 
under wing-coverts and axillaries dusky-brown, with a few white spots and bars; quills dusky below ; bill green, darker at tip ; legs, feet, and claws olive ; iris crimson. Total length, 7 inches; culmen, 075 ; wing, 3.5 ; tail, I*75; tarsus, $1{ }^{\circ} \circ 5$; middle toe and claw, $1 \cdot 5$.

winter Plumage.-Appears to have a whiter throat than in summer, and in all probability the entire throat gradually becomes slaty-grey as the breeding season approaches; bill grass-green, the culmen dusky; tarsi and toes greenish; iris reddish orange.

Young.-Is like the adult on the upper surface, and is similarly marked with black and white, but the general tone of the plumage is rather more rufous; the head is like the back; sides of the face rufous-brown, as also the eyebrow; lores whitish; throat, breast, and abdomen dull white; the foreneck and chest rufescent, barred across with dusky; lower flanks, vent, and under tail-coverts black, barred wich white; iris light ashy-brown.

The young birds probably do not attain their full grey plumage for at least a year, as a specimen (in the British Museum), procured near Potchefstroom on the $24^{\text {th }}$ of April, is still in immature plumage, like the young bird above described, and differs only in the whiter under surface, the fore-neck and chest alone retaining some remains of rufous shading and dusky bars. The eyebrows are whitish and more distinct. If this bird was going to moult into the grey plumage before its return to Europe, the change must be very rapidly performed.

Nestling.- "Shiny black, with a yellowish bill and legs of a greenish slate-colour" ( $W$. C. Tait).

Characters.-In the foregoing species the axillaries are barred with white. In Baillon's Crake they are uniform. The back is freckled and spotted with white, as are the wingcoverts in a less degree. The ear-coverts are bluish-grey or ashy.

Range in Great Britain.-A visitor in spring and autumn, principally to our southern counties, though it has been captured in Derbyshire and Yorkshire. It has also occurred 
in the Isle of Man, twice in Scotland, and twice in Ireland. It prohably breeds occasionally in England, as two nests, apparently of this species, were found in Cambridgeshire in 1858, and two more in Norfolk in 1866.

Teange outside the British Islands.-Baillon's Crake appears to be somewhat irregularly distributed throughout Central and Southern Europe, as it is not known from the Baltic Provinces or Poland, but it extends (in winter, probably) to the Persian Gulf, being replaced in Eastern Siberia, India, and China by the allied species, $P$. pusilla. It occurs in suitable localities throughout Africa, and the place from which I have seen the greatest number of specimens is Madagascar.

Habits.-The habits of Baillon's Crake resemble those of its congeners, but, from its small size, it is even more difficult of observation.

Nest. - Small, made of rushes and reeds.

Eggs.-Six to eight in number. Olive brown, mottled with reddish-brown, and dull grey underlying spots, the latter not much in evidence. The mottling is obscure, and some eggs appear almost uniform olive or reddish-brown. Axis, $\mathrm{I} \cdot \mathrm{I}-\mathrm{r} \cdot \mathbf{2}$ inch ; diam., $0^{\circ} 75^{-0} 9$.

THE MOOR-HENS. GENUS GALLINULA.

Gallinula, Briss. Orn. vi. p. 3 ( 1760 ).

Type, G. chloropus (Linn.).

The Water-Hens are distinguished by their red frontal shield, the plumage being sombre and generally blackish. The toes are long, the middle one and its claw exceeding the tarsus in length; they have a narrow lateral membrane, but do not have a scalloped lobe like the Coots. The secondaries are decidedly shorter than the primaries. The nostrils are oval, and situated in a distinct nasal depression.

I. THE MOOR-HEN. GALLINULA CHLOROPUS. Fulica chloropus, Linn. Syst. Nat. i. p. 258 ( I 766 ). 
武

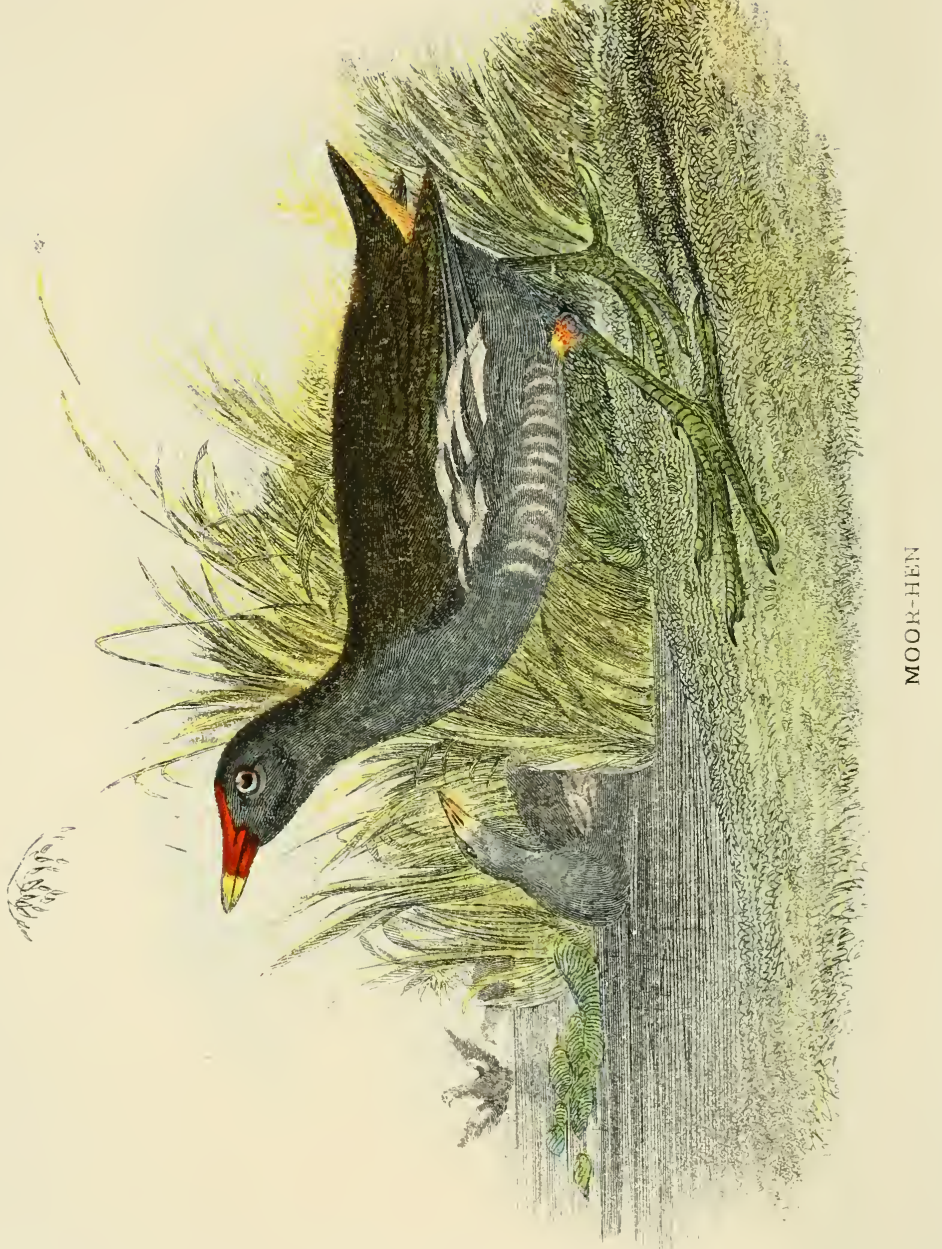


Gallinula chloropus, Macgill. Brit. B. iv. p. 547 (1852); Dresser, B. Eur. vii. p. 3I3, pl. 503 (1879); B. O. U. List Brit. B. p. I5 I (1883); Saunders, ed. Yarrell's Brit. B. iii. p. 164 (I883); Seebohm, Hist. Brit. B. ii. p. 557 (I884) ; Saunders, Man. Brit. B. p. 503 (I889) ; Lilford, Col. Fig. Brit. B. part xix. (I89I); Sharpe, Cat. B. Brit. Mus. xxiii. p. I 7 I (1894).

\section{(Plate CXIX.)}

Adult IIale.-General colour above dark olive-brown, with reflections of ruddy brown; scapulars like the back; wingcoverts slightly more ashy and washed with olive-brown, especially towards the ends; bastard-wing, primary-coverts, and quills blackish-brown, externally washed with ashy-brown, the outer bastard wing-feathers and first primary externally edged with white; the innermost secondaries more ruddy brown and washed with olive like the back; tail-feathers blackish, with a slight wash of olive-brown ; crown of head and sides of face blackish, fading off into dark slaty-grey on the sides of the neck and hind-neck; throat also blackish, fading off into dark slaty-grey, the same as the rest of the under surface; the lower flanks washed with brown, the sides of the body broadly streaked with white, which occupies the greater part of the outer feathers; abdomen more or less varied with white edges to the feathers; under tail-coverts white, with the feathers of the vent and the long median tail-coverts black; under wing-coverts and axillaries ashy-grey, tipped with white, the bend of the wing edged with white; frontal shield and twothirds of the bill deep lake-red, the tip of the latter greenishyellow for about one-third; legs olive-green, the broad scaling on the fore part of the tarsus, and the scales on the upper part of the toes, lemon-yellow ; joint of heel dusky olive-green, with a shade of lemon-yellow immediately below the garter, which is dark lake-red; iris reddish. Total length, $\mathbf{I}^{2} \cdot 5$ inches; culmen, with frontal shield, $1{ }^{\circ} 55$; wing, 7.3 ; tail, 2.9 ; tarsus, I. 85 ; middle toe and claw, 2.95 .

Adult Female.-Similar to the male in colour, but having the white streaks on the flanks not quite so broad. Total length, I I'5 inches; wing, 6.4 . 
Young.-Browner than the adult, the head a little more dusky-brown than the back; sides of face dark brown; throat white, with dusky bases to the feathers; rest of under surface brown, the feathers edged with white; abdomen entirely white; the flank-stripes buffy-white and very narrow; bill black, dull red along edge of tomium and on lower mandible; legs fleshybrown, darker on the tarsal joint and toes; claws light hornbrown.

The young bird gains the adult plumage in the following spring, by the shedding of the brown or whitish margins of the feathers of the under surface, so that the grey plumage of the adult gradually supervenes.

Range in Great Britain.-The Moor-Hen is found all over the British Islands, and is resident, a slight southern migration taking place when severe winters reign in the north. It is equally widely distributed in Ireland as in England and Scotland.

Range outside the British Islands.-The present species is found over the greater part of the Old World, but does not range very far north, breeding sparingly in Scandinavia up to $63^{\circ} \mathrm{N}$. Lat., and in Russia as far as the S. Petersburg district. In China and the Indo-Malayan region the Moor-Hens are somewhat smaller in size, but the bird from Africa and Madagascar (so-called G. pyrrhorhoa) is the same as our own European bird. In America an allied species of Moor-Hen (G. galeata) replaces $G$. chloropus, and in Australia the latter species is represented by $G$. tenebrosa and in the Moluccas by G. frontata.

Habits.-This bird is not an inhabitant of the moors, as its name might seem to imply, but of our rivers, lakes and marshes, and the word "moor," as Mr. Saunders points out, is the equivalent of the old word " mire," or " marsh." A very small sheet of water, even a small pond, if it is sufficiently surrounded by rushes or studded with weeds, is enough to attract a MoorHen, and within a hundred yards of the room in which I am now writing at Chiswick (March, I897), a pair of birds are preparing to make their nest in a neighbour's pond, where they have bred for several years in succession. Given a little encouragement, and the Moor-Hen becomes very tame, and will walk about the lawn and even come close to the house for food. 
Although its principal food consists of worms, insects, and seeds of plants, it is accused of eating young birds and eggs of other species, and I remember at least one place where the Moor-Hens were looked upon with great disfavour as devourers of Pheasants' and Ducks' eggs, and when Ducks or Snipe were absent from the water meadows, a hunt with the dogs was instituted after the Gallinules. These, after a little disturbance, would take to the trees, and on one occasion I myself shot eleven Moor-Hens out of one clump of willow bushes. I am also certain that they occasionally roost in trees, as I have found them late at night in evergreens, many hundred yards from any water, when I have been moth-catching. They are shy during the breeding season, but by remaining perfectly still, the observer may see the pair of old birds emerge from the reeds, and swim about with their nestlings, the latter being clad in black down, the female being always most solicitous of the welfare of the latter, and uttering a clucking note as she moves about, her white under tail-coverts being flirted as she swims, and the red garter above the tarsal joint always showing plainly.

Nest.-Generally a rounded and firmly built structure of dry reed-flags and sedge, placed among the reeds on the edge of a pond, or on the sides of a lake or river, but occasionally built on a branch above the water level, and it has even been known to be located in a tree twenty feet above the ground.

Eggs.-From seven to nine in number. Ground-colour, stone-buff to reddish clay-colour, spotted with reddish-brown; these spots seldom very large, often tending to black, and in some specimens reduced to a sprinkling of dots. The underlying spots are dark purplish-grey, and are often scarcely distinguishable from the overlying ones. The eggs vary very much in shape. Axis, $\mathrm{I}^{\cdot} \mathrm{I}_{-\mathrm{I}} \mathrm{I}^{\circ} 95$ inches ; diam., $\mathrm{I}^{\cdot} \mathrm{I}-\mathrm{I}^{*} 4$

\section{THE PURPLE GALLINULES. GENUS PORPIIYRIO.}

Porphyrio, Briss. Orn. vi. p. 522 (1760).

Type, $P$. porphy'rio (Linn.).

These large and brightly-coloured Rails differ in their horny bills, which are very deep, and have no nasal depression, but 
have rounded nostrils. They are birds of tropical countries, being found from the Mediterranean eastwards to India, and as far as Australia and New Zealand. Two species, the Green-backed Gallinule, $P$. porphyrio of Africa, and the Purple Gallinule, $P$. caruleus of the Mediterranean countries, have been recorded as having been captured in England; but as they are both species which are often kept in captivity in this country, there is no reason to believe that the specimens were otherwise than escaped birds, as neither of them are likely to migrate, or be driven, from their swampy fastnesses.

The eggs of $P$. porphyrio are larger than those of a Moor. Hen, but otherwise resembles them.

\section{THE COOTS. SUB-FAMILY FULICINA.}

These birds are like great Moor-Hens, but are distinguished from them, and from the other Rails, by the scalloped lobes on the toes. There is generally a white or reddish shield on the forehead, and the bill, in some of the exotic species, partakes of the bright colours of the shields.

The Coots are found over nearly every part of the Old and New Worlds, and are strongly represented in South America, where they attain their largest size.

\section{THE COMMON COOT. FULICA ATRA.}

Fulica atra, Linn. Syst. Nat. i. p. 257 ( 7 66); Macgill. Brit. B. iv. p. 560 (1852); Dresser, B. Eur. vii. p. 327 , pl. 504, fig. 2 (I 879 ); B. O. U. List Brit. B. p. I5 I (I883); Saunders, ed. Yarrell's Brit. B. iii. p. I 7 I ( 1883 ); Seebohm, Hist. Brit. B. ii. p. 564 (1 884$)$; Saunders, Man. Brit. B. p. 505 (1889); Lilford, Col. Fig. Brit. B. part xxxi. (1895); Sharpe, Cat. B. Brit. Mus. xxiii. p. 2 I I (I894).

\section{(Plate CXX.)}

Adult Male.-General colour above cindery-grey with a slight olive shade on the back; wing-coverts also cindery-grey, the outer feathers of the bastard-wing edged with white; quills ashy-brown with dusky tips, the first primary inclining to whitybrown on the outer web; the outer secondaries whitish at the 

四

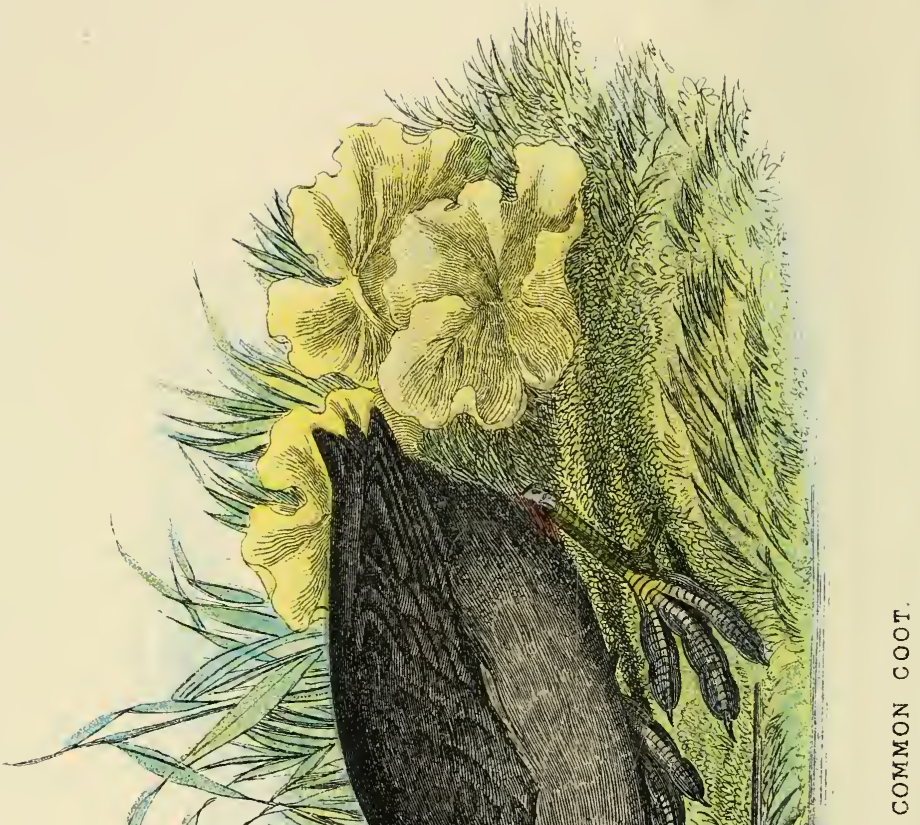


ends ; the innermost secondaries washed with cindery-grey like the-back; tail black; head, hind-neck, and throat black; remainder of under surface of body light slaty-grey, with slight remains of ashy margins to the feathers of the chest and centre of the breast ; under wing-coverts slaty-grey, with a line of white feathers round the bend of the wing; under tail-coverts black; bill very pale lavender, with a pinkish tinge; frontal shield ivory-white ; tarsi and feet pearly-grey, with a greenish tinge on the sides of the tarsus; garter orange-yellow; iris dark brown. Total length, 14.5 inches; culmen, from base of shield, $1 \cdot 35$; wing, $8 \cdot 6$; tail, $2 \cdot 2$; tarsus, $\mathrm{r} \cdot 3$; middle toe and claw, 3.85 .

Adult Female.-Similar in plumage to the male, but slightly smaller. 'Total length, I 4 inches; wing, $8 \cdot 1$.

Young.-Much browner than the adult, the feathers of the head dusky black edged with white; lores, eyebrows, and sides of face white; under surface of body ashy-whitish, browner on the flanks.

Nestling.-Black, with white filamentous tips to some of the down; head bare.

Range in Great Britain.-The Coot occurs everywhere from north to south in Great Britain, where localities suited to its habits are to be met with, such as large ponds, lakes, and quiet rivers. In some places, especially in the South of England, such as Slapton Ley in Devonshire, and Poole Harbour, the Coots appear in winter in large numbers, particularly when they are frozen out of their more northern haunts. In Ireland the species is reported to breed in every county, though it is more local than the Moor-Hen.

Range outside the British Islands. - The Coot is found over the greater part of Europe and Asia, but does not range beyond the Mediterranean, nor further than the Indo-Malayan Islands in Asia. The northern range of the species extends occasionally to S.IV. Iceland, and it has even been recorded from Greenland, while in Norway it nests up to $70^{\circ} \mathrm{N}$. Lat.

Habits.-The Coot prefers larger sheets of water than the Moor-Hen, and does not take up its abode on such small ponds as the last-named bird oftentimes affects. I) uring the breeding 
season it frequents lakes, and several nests may be found in the space of a few hundred yards, and at that season of the year the Coot is a retiring bird and keeps more to the reeds than to the open water. Of an evening, however, they may be seen slowly swimming about, when the white shield on their forehead renders them easily recognisable from the Moor-Hens. In the autumn they congregate together, and will associate with the Ducks on a decoy, so much so, that I have often seen a great many killed during a day's Duck-shooting. They trust to escape more by swimming under the overhanging branches of the trees and bushes than by flight, though a Coot, when once launched on the wing, is a powerful flier. In the winter vast numbers used to congregate in Pagham Harbour, and the same may be said of Poole Harbour.

Nest.-A round and compact structure of dry flags, built in the shallow water, near the edge of a lake, and resting on a foundation of reeds. The example in the Natural History Museum, which I took years ago on Sir Edward Shelley's lake at Avington, was decorated with marigolds, which were intertwined among the flags forming the rim of the nest.

Eggs.-From seven to ten in number, though Mr. Robert Reed tells me that eight is the largest number he has ever found in a Coot's nest. Ground-colour stone-buff or pale clay-colour, sometimes inclining to olive, the whole of the surface minutely dotted with dark brown or blackish spots, the underlying spots being purplish-grey, and equally plentifully distributed. Axis, I $9-2 \cdot 2$ inches; diam., I $35^{-I} \cdot 15$.

\section{THE PIGEONS. ORDER COLUMBIFORMES.}

In the Pigeons the bill is schizognathous, and the nasals are schizorhinal, with basipterygoid processes present and placed medially. The primary-quills are eleven in number and the fifth secondary is absent. The hind-toe is connected with the flexor longus hallucis tendon, and not with the flexor perforans digitorum; the two deep plantar tendons not being free, but united by a "vinculum." The hind-toe is on the same level as the others. The bill is swollen at the tip, the latter being hard and convex, while the basil portion is covered 



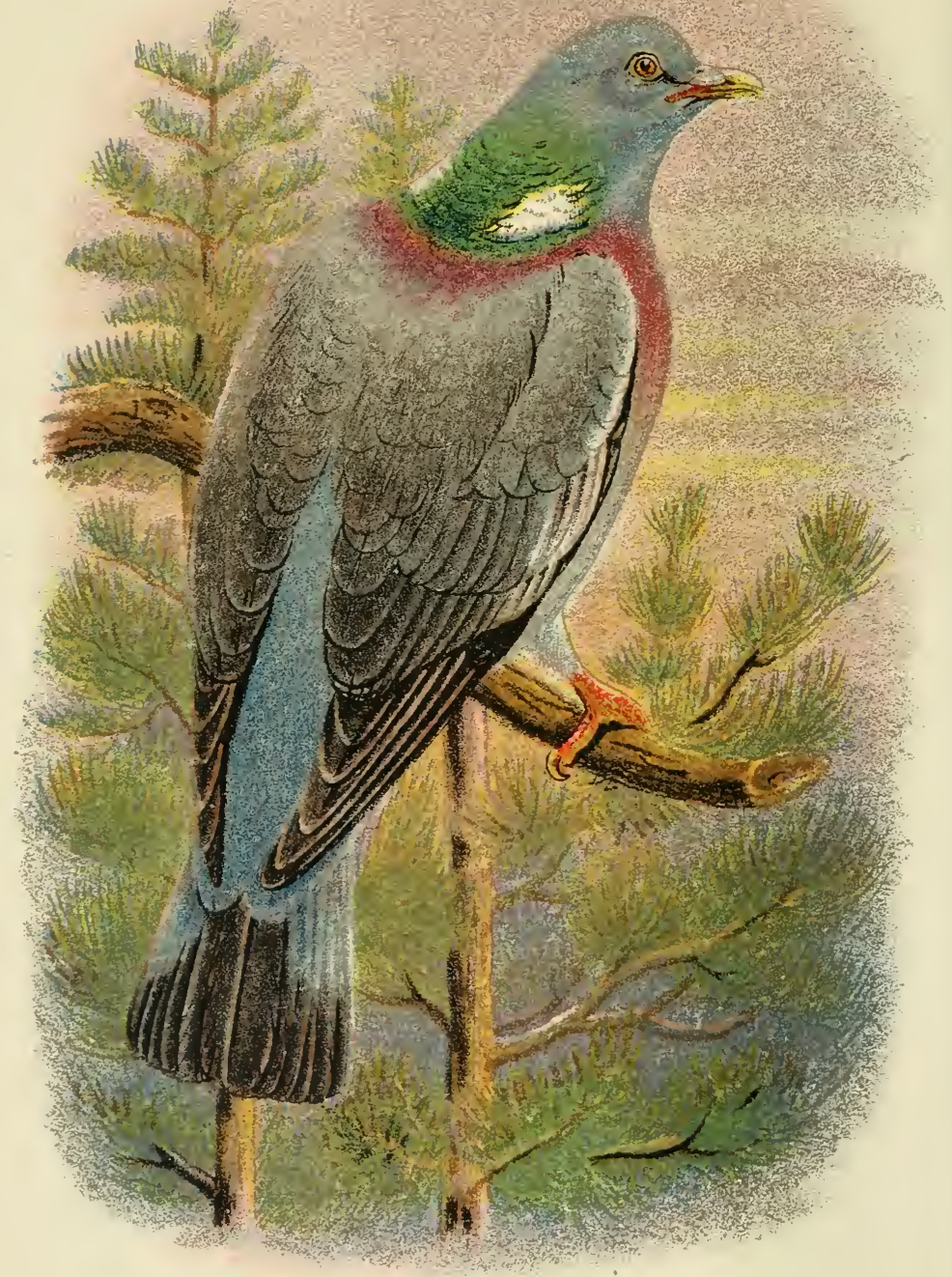

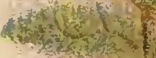

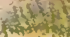
mutely)

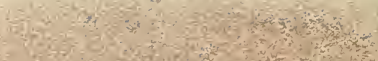

WOOD-PIGEON. 
by a soft skin, in which the nostrils open, overhung by an incumbent valve. (Cf. Salvadori, Cat. B. Brit. Mus. xxi. p. I.)

Pigeons are found over the greater part of the globe, and they are divided by Count Salvadori into five families: Treronide (Fruit-Pigeons), Columbida (True Pigeons), Peristerida (Ground-Pigeons), Gourida (Crowned Pigeons), and Didunculide (Tooth-billed Pigeons.)

\section{THE TRUE PIGEONS. FAMILY COLUMBIDA.}

These Pigeons have a rather short tarsus, generally shorter than the middle toe. In this respect they show that they are Tree-Pigeons, as opposed to the Peristerida or GroundPigeons, and they have a near relationship to the Treronida or Fruit-Pigeons. The latter, however, have very broad soles to the feet, and have from fourteen to sixteen tail-feathers, whereas the Columbida have the soles normal and not very broad, the hind-toe only with the skin prominently expanded on the sides, while the tail-feathers are twelve in number. (Cf. Salvadori, $o p$. cit. p. 3 ).

Count Salvadori divides the family Columbida into three subfamilies - the Columbina, with the tail of moderate length, not longer than the wings, and the Macropygiince and Ectopistina, in which the tail is longer than the wings.

\section{THE WOOD-PIGEONS. GENUS COLUMBA.}

$$
\begin{aligned}
& \text { Columba, Linn. Syst. Nat. i. p. } 279 \text { ( } 1766) . \\
& \text { Type, C. livia (Bonn.). }
\end{aligned}
$$

In this genus the tail is shorter than the wing, and the tarsus is feathered for a small extent on the upper half, but not for more than half its length.

About sixty different kinds of Wood-Pigeon are known, and they are found in every part of the Old World, and throughout the New World also, except in the more northern parts.

\section{THE WOOD-PIGEON. COLUMBa PALUMBUS.}

Columba palumbus, Linn. Syst. Nat. i. p. 282 ( 1766 ); Macglll. Brit. B. i. p. 259 (1837); Dresser, B. Eur. vii. p. 3, pl. $45^{6}$ 
(I 878 ) ; B. O. U. List Brit. B. p. 138 (1883); Saunders, ed. Yarrell's Brit. B. iii. p. I (1883); Seebohm, Hist. Brit. B. ii. p. 396 (1884); Saunders, Man. Brit. B. p. 467 (1889); Salvad. Cat. B. Brit. Mus. xxi. p. 299 (1893); Lilford, Col. Fig. Brit. B. part xxxii. (I 896 ).

\section{(Plate CXXI.)}

Adult Male-General colour above slaty-drab, the wingcoverts like the back, the greater series a little clearer slatecolour; the outer wing-coverts of all the series white, forming a band round the edge of the wing; bastard-wing and primary coverts slaty-black; quills brown, externally slaty, lighter at the base of the outer secondaries, the primaries all edged externally with white; lower back, rump, and upper tail-coverts clear bluish-grey; upper surface of tail bluish-grey, the terminal third blackish; under surface of tail slaty-black at the base and at the end, with a broad band of light grey in the middle; head and neck bluish-grey, glossed with metallic green and lilac on the hind-neck; on the sides of the neck a large patch of creamy-white feathers, the lower part of the hinder-neck and the lower sides of the neck glossed with metallic lilac; sides of face and throat bluish-grey, paler towards the chin; under surface of body from the lower throat to the breast vinous or lilac, with the abdomen, sides of body, and under tail-coverts pale bluish-grey, like the under wing-coverts, axillaries, and quill-linings, the latter being a shade lighter grey ; bill orangered at the base, yellow towards the tip, the membrane covering the nostrils almost white; tarsi and feet bright red; iris strawyellow. Total length, 16 inches; culmen, 0.85 ; wing, 9.8 ; tail, 5.4 ; tarsus, $I \cdot 25$.

Adult Female.-Similar to the male, but a little smaller. Total length, $15^{\circ} 5$ inches ; wing, 9.5.

Young Birds.-Resemble the adults, but are duller and paler in colour, and have no white patch on the side of the neck; the bill is dull red at the base, greyish towards the tip.

Nestling.-Leaden-grey, covered with hairy down of a strawyellow colour.

Range in Great Britain.-The Wood-Pigeon is generally distributed throughout England and Wales, receiving large additions 
to its numbers during the autumn migration. It is gradually extending its range northward, and is now common in the Lothians and other districts of Scotland, where it was unknown but a short time ago. The same may be said of the IVest of England, but in every county of Ireland it breeds numerously, according to Mr. Ussher, though in the treeless districts it is seldom seen.

Range outside the British Islands.-The present species is found throughout the Western Palæarctic Region, and extends eastward to Northern Persia, being replaced in South-eastern Persia, Central Asia, and the North-Western Himalayas as far as Nepal by Columba casiotis, which has the neck-patches fulvous, or clayey cream-colour (Salvadori). In most parts of Europe the Wood-Pigeon is a resident, and it breeds as far north as $65^{\circ}$ or $66^{\circ} \mathrm{N}$. Lat.; but those birds, which nest in more northern latitudes, migrate south as winter approaches, mostly coming over to Great Britain like the Starlings.

Habits.-In a wild state the Wood-Pigeon is one of the shyest of birds, as it is also one of the most wary; but during the breeding season, when once the fenrale has begun to sit, they are more easy of observation. I remember how, when a school-boy, I found a nest in an isolated tree, a small elm. The nest was placed in the fork of a branch against the stem, and was rather difficult of access. My mind was bent at that time upon possessing a live Wood-Pigeon to take home for the holidays along with my other pets (I had eighty birds of different sorts in a stable-loft at the time, Barn-owls, Kestrels, Jackdaws, Mistle-Thrushes, etc., etc., etc.!!). The young Pigeons, however, appeared determined not to be hatched out before my departure for home, so I resolved to catch the old bird if possible. The tree, as I said before, was not an easy one to climb, but I essayed it one morning soon after daybreak, when the hen bird was sitting hard, and I managed to reach the nest and place my hand on the sitting bird; but not quite far enough, as she flew off suddenly, and left the whole of her tail in my hand!

The Wood-Pigeon creates great havoc among the peas, and I remember once meeting a well-known Cookham gunner 
returning very early one morning with eight Wood-Pigeons in his hands, and I asked him how he got them. "At one shot," he replied, "Mr. Mills told me that the Pigeons were working his peas, and asked me to scare them if I could. So I went down to Widbrook, and hid myself behind the hedge on the common. After a long wait, I saw a bird walking among the peas and fired at it. On going to pick it up, I found seven others had been knocked over at the same time." Besides peas and grain the Wood-Pigeons devour great quantities of beech-mast, and I have more than once shot them from beech woods, when their crops have been so full of mast, that they have actually split open with their fall.

At the present day one does not need to go to the woods to study the habits of this pretty bird, for it is now a plentiful inhabitant of the London parks. Years ago I have seen them stalking about quite tamely in the Champs Elysées and the gardens of the Luxembourg, in Paris, and now they are equally tame in Kensington Gardens and St. James's Park, in London, and one pair, at least, seems to have taken up their abode in the grounds of the Natural History Museum, during the present spring ( 1897 ).

Nest.-This is a poorly constructed platform of crossed twigs, and is placed in all kinds of situations; in low bushes, in high trees, in thick ivy, and sometimes on the deserted nests of other birds, or squirrels. When placed in a thorn-bush or some such situation, the framework of the nest is so slight that the white eggs can be seen through the twigs from below.

Eggs.-Two, exceptionally three, in number. Pure white,

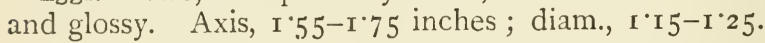

II. THE STOCK-DOVE. COLUnBA CENAS.

Columba cenas (pt.), Linn. Syst. Nat. i. p. 279 (I 766) ; Macgill. Brit. B. i. p. 287 (1837); Dresser, B. Eur. vii. p. 23, pl. 458 (1876); B. O. U. List Brit. B. p. I38 (1883); Saunders, ed. Yarrell's Brit. B. iii. p. 8 ( 1883 ); Seebohm, Hist. Brit. B. ii. p. $40 \mathrm{r}$ (1884); Saunders, Man. Brit. B. p. 469 (1889); Lilford, Col. Fig. Brit. B. part xx. (1891); Salvad. Cat. B. Brit. Mus. xxi. p. 26 I (1893). 



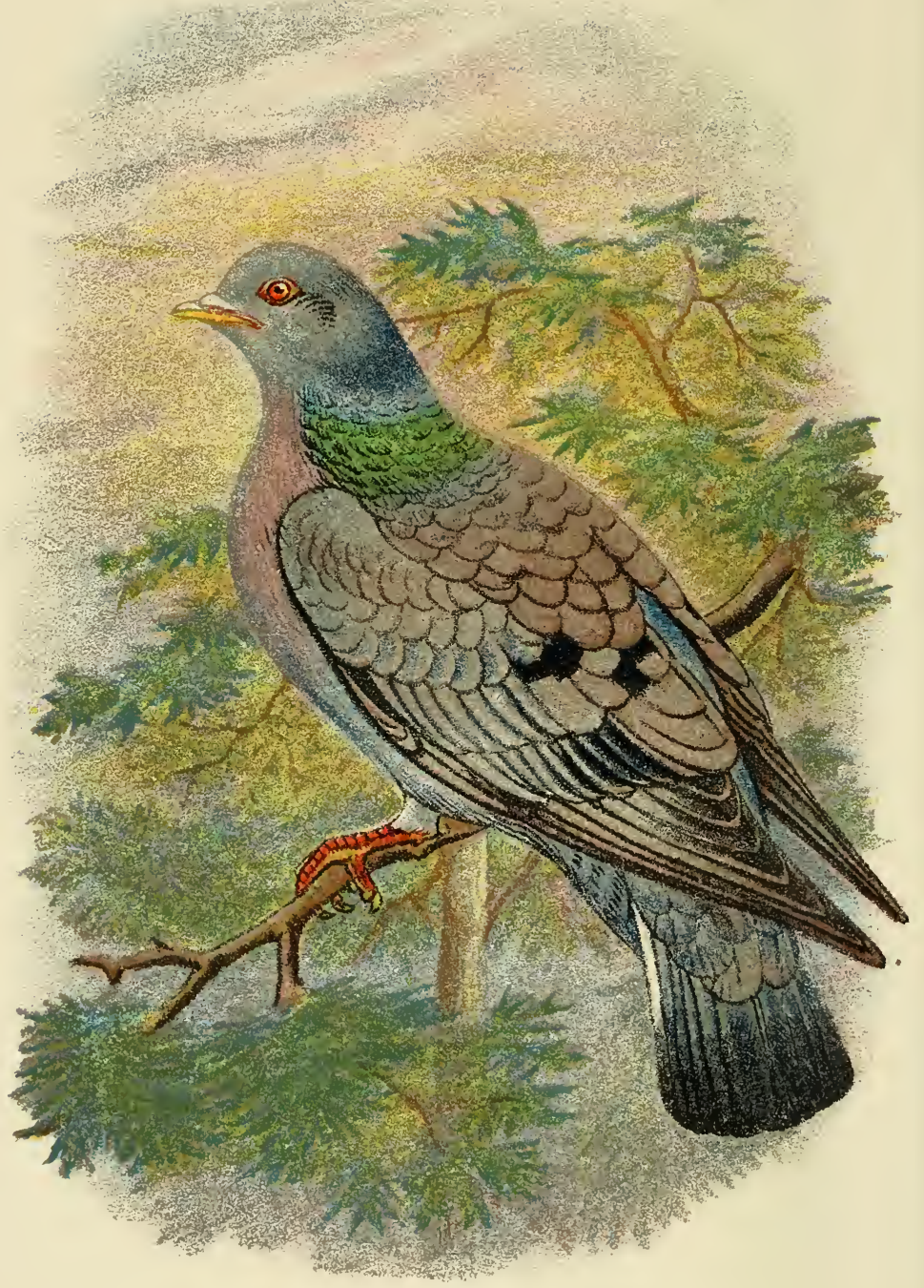


Adult Male.-General colour above drab grey; the wingcoverts like the back, but a little clearer grey, especially on the greater series, two of the innermost of which have black bases, forming a double spot on the wing; bastard-wing, primarycoverts, and quills blackish, bluish-grey on the inner webs of some of the primary-coverts, and on the base of the outer webs of the inner primaries and outer secondaries, the inner secondaries almost entirely grey, and the innermost resembling the back, with a black spot in the middle of the outer web of two of them, forming another double spot on the wing; lower back, rump, and upper tail-coverts clear bluish-grey; tail bluish-grey, black for the terminal third, the under surface of the tail blackish, with a grey sub-terminal band; head and throat bluish-grey, with a dusky patch on the ear-coverts; sides of neck and hind-neck glossed with metallic-green and lilac; lower throat, fore-neck, and chest delicate vinous, fading off into the delicate pearly grey of the rest of the under parts ; the under tail-coverts slightly darker bluish-grey, with pale pearlygrey margins to the feathers; the under wing-coverts and axillaries also somewhat darker grey than the breast; bill red at base, yellow towards the tip, and grey on the soft part of the base of the upper mandible; feet pinkish red; iris red. Total length, I4 inches; culmen, 0.8 ; wing, 8.2 ; tail, $4^{\circ} \circ$; tarsus, $I \cdot 2$.

Adult Female.-Similar to the male, but a little smaller and duller in colour. Total length, 13.5 inches; wing, 8.5 .

Young.-Duller in colour than the adults; the green colour wanting on the neck, and the black spots on the wings obsolete.

Characters.-The smaller size, the lack of the large white patches on the sides of the neck, and the absence of white round the bend of the wing and on the outer wing-coverts, as well as the presence of the four black spots on the wing, caused by the bases to two of the inner greater coverts and two of the inner secondaries being black, distinguish the StockDove from the Wood-Pigeon.

Range in Great Britain.-The Stock-Dove, like the WoodPigeon, is found in most parts of England, and is extending its range northward in Scotland. Mr. Ussher also reports that 
it is spreading in Ireland. "It breeds," he says, "in Antrim, Down, Armagh, Louth, and Wicklow, and doubtless also in King's and Queen's Counties, where it is reported to be seen more or less frequently ; also recently in Carlow, though formerly unknown there. Still scarce and local.

Range outside the British Islands.-The Stock-Dove inhabits the whole of the Western Palæarctic Region, and extends eastward to Turkestan and Northern Afghanistan and LobNoor. In Scandinavia and Russia it breeds up to about $60^{\circ}$ or $61^{\circ} \mathrm{N}$. Lat.

Habits.-The Stock-Dove has somewhat different habits from those of the Wood-Pigeon. It is seldom found in flocks, like the latter bird, and more often is met with singly. I have often flushed the Stock-Dove from the dense thickets of small branches which grow at the foot of ancient lime-trees, and become choked with dead leaves; but I never could discover that it was nesting in these situations, though the cover was dense enough to afford it the shelter which the bird loves, and there was probably some hole in the tree itself which I failed to discover. In old elm-trees covered with ivy I have often found it nesting, and seeking the same kind of hole as the Jackdaws, which also nested, in the proportion of six to one of the Stock-Doves, in the same cluster of hoary eims. Like the Wood-Pigeon, the Stock-Dove resorts to some favourite and retired clump to roost; but whereas the former bird often selects a dense grove of yews or fir-trees on some island in a lake, I have never found the Stock-Doves resorting to such haunts. Above the old yew-avenue in Avington Park are many elm and ash trees, and to these the Stock-Doves used to resort as evening closed in, and I have procured several specimens for the British Museum by waiting for them in the twilight, when they used to flock into the high trees, doubtless intending to descend later on to roost in the shade of the great yews. The food of the Stock-Dove is very similar to that of the Wood-Pigeon, but I have never known the latter bird to show any preference for mustard-seed, whereas the Stock-Dove and the Turtle-Dove do great damage to the mustard-fields when the seed is ripe. In winter the Stock-Dove often mixes with the flocks of Wood-Pigeons. 
Nest.-Composed only of a few sticks or roots, and very frequently there is none at all, the eggs being laid on the wood at the bottom of a hole, or on the bare sand in a rabbit-burrow. Mr. Robert Read writes to me:-" I have found fresh eggs of this bird in Somersetshire as early as March and as late as September, in both instances in the hollow head of a pollard willow. I have also taken the nest from a rabbit-hole in a wooded hill-side." The species also breeds in holes of trees and cliffs, on beams in old church towers, old nests of other birds, and squirrel's dreys.

Eggs.-Two. Pure glossy white. Axis, $\mathrm{I}^{\cdot} 5^{-\mathrm{I}} \cdot 65$ inches; diam., $I \cdot I-I \cdot 25$.

III. THE ROCK-DOVE. COLUMBA LIVIA.

Columba livia, Bonn. Enc. Méth. i. p. 227 ( (790); Macgill. Brit. B. i. p. 268 (I837) ; Dresser, B. Eur. vii. p. I I, pl. 457 (г879); B. O. U. List. Brit. B. p. I39 (I883); Saunders, ed. Yarrell's Brit. B. iii. p. I 3 ( 1883 ); Seebohm, Hist. Brit. B. ii. p. 405 (1884) ; Saunders, Man. Brit. B. p. 47 I (I889); Salvad. Cat. B. Brit. Mus. xxi. p. $25^{2}$ (1893) ; Lilford, Col. Fig. Brit. B. part xxx. (เ895).

Adult Male-General colour above delicate grey; the wingcoverts like the back, the greater series with a black band across the middle, forming a wing-bar; bastard-wing, primarycoverts, and quills grey, dusky on the outer webs and at the ends; the secondaries grey at the base, with broad blackish ends; the inner secondaries black, with a sub-terminal bar of grey, the innermost grey towards the ends, which have a narrow dusky edging; lower back pure white; rump and upper tail-coverts slaty-blue, a little darker than the back; tail-feathers slaty-blue, with a broad sub-marginal band of black ; crown of head slaty-blue, as also the sides of the face and throat; the sides of the neck and the entire hind-neck metallic lilac or green, according to the light, this metallic colour extending all over the fore-neck and chest; remainder of the under surface of the body clear slaty-grey, a little darker on the under tail-coverts; under wing-coverts and axillaries white, with the edge of the wing grey, the quill- 
lining ashy-whitish ; bill vinous slate-colour, inclining to white on the cere; feet red; iris orange-red. Total length, I3 inches; culmen, 0.75 ; wing, 895 ; tail, 3.9 ; tarsus, $\mathbf{I}^{\circ} \mathbf{5}$.

Adult Female.-Similar to the male, but somewhat smaller. Total length, $12 \cdot 5$ inches; wing, $8 \cdot 3$.

Young.-Differs from the adult in its more dingy coloration, and in the pale fringes to the wing-coverts. The metallic colour on the neck and chest is almost entirely absent, these parts being dusky slate colour; the lower back is white as in the adults.

Characters.-The white on the lower back at once distinguishes the Rock-Dove from the Wood-Pigeon and the Stock Dove. Like the latter it has no white patches on the sides of the neck, which are metallic; but instead of the four black spots on the wing-coverts, the wing is crossed by a black band across the greater coverts. There is a second black band, in both species, formed by the ends of the secondaries; but in the Rock-Dove the innermost secondaries are crossed with a black band, whereas in the Stock-Dove these quills resemble the back, and only two of them show a black spot on the outer web.

Pange in Great Britain.-The Rock-Dove breeds in a wild state on the cliffs of Scotland and the Orkneys and Shetlands, and its range can be traced from Devonshire and Cornwall, where it is very local, along the west of England and Wales, but on the east coast of England it is only found on Flamborough Head, and in Northumberland. Mr. Ussher says that it breeds in the sea-cliffs nearly all round Ireland.

Range outside the British Islands.-Count Salvadori says that the range of the Rock-Dove extends throughout the Western Palæarctic Region, eastwards to Sind, Cashmere, and some parts of India. In many countries it crosses with the domestic Pigeon, and varies considerably in plumage in consequence, so that several supposed species have been named upon these differences. It seems to be nowhere very common in Europe, excepting, as Mr. Saunders points out, in mountainous regions, such as the Pyrenees and the various ranges of Spain and Italy. 
Habits.-The late I)r. Saxby has given the following account of the habits of the Rock-I)ore in the Shetlands:-

"It is not very difficult to approach under ordinary circumstances, and, when feeding in flucks among stubble, is so intent upon its work as to allow the shootcr to walk boldly up within range; but in neighbourhoods where it is often disturbed it is fully as shy as the Wood-Pigeon. It is easy to shoot the Doves as they fly in and out of their caves ; but the practice is dangerous, from the risk one runs of shaking down loose fragments of stone, as well as cruel, on account of the impossibility of entering the caves in any but the calm weather of the more genial seasons of the year, when, of course, the birds are breeding.

"The Rock-Dove feeds in company with various other species, such as Redwings, Twites, Buntings, and tame Pigeons; and it is owing to the latter circumstance that parti-coloured birds are so frequently met with in the flocks. In winter, during hard frost, it descends to the shingly beaches, where it picks up small seeds among the weathered plants above high-water mark.

"It is difficult to convince farmers that at least it does some little good. But in this case, as in all other similar cases, the wisest course is nierely to give a simple, unprejudiced record of facts, leaving truth to work its own way, as it inevitably will in the end. To state that any living thing is probably useful to mankind, is but to divide one's hearers into two classes, the one clamouring for its extermination, the other prepared to protect it to an injurious extent; and a precisely similar result would have been sure to follow an opinion that it was useless or hurtful. When its enemies see it upon the sheaves, they at once begin to argue as if this were its constant habit all the year round, and they enter into the most intricate calculations as to the probable number of bushels thus consumed during the twelve months. Similarly, its would-be friends are triumphant when, on opening the crop of a Rock-Dove shot in a stubble field, some considerable time after the corn has been cleared, it is found to be filled with the seeds and roots of noxious weeds, with merely a few grains of oats or barley intermixed, quite overlooking the fact, that had the grain been abundant the weeds would have been despised, as indeed I have ascertained 
by experiment with these birds in confinement. During, say, ten months in the year, when corn is not to be procured, the Rock-Dove subsists chiefly upon the roots of the couch-grass (Triticum repens), and the seeds of various troublesome weeds, such as Sinapis arvensis, Raphanus, Raphanistrum, Plantago maritima, and Capsella bursa-pastoris. There can be no doubt that it greatly prefers grain to all other food, and will consume it in enormous quantities; therefore, if the farmer cannot convince himself that the evil is counterbalanced by the good, and finds his interests suffering, then by all means let him save his pocket by thinning the ranks, but also let him pause ere he attempt the dangerous experiment of total extermination."

Nest.-According to Messrs. Kearton, who have given a photograph of one of the caves in North Uist, where RockDoves and Shags were breeding in company, the nest is a small collection of twigs, sticks, seaweed, and bents, roughly constructed, and flat. It is placed on ledges and clefts of maritime and inland cliffs, generally the former.

Eggs.-Two in number, glossy white. Axis, $I_{5}$ to $I \cdot 65$ inches; diam., $\mathbf{I}^{\cdot} \mathbf{1}^{-1} \mathbf{I}^{\cdot} 2$.

\section{THE POINTED-TAILED PIGEONS. SUB-FAMILY ECTOPISTINÆ.}

In these American birds the tail is very peculiar, being not only longer than the wing, but narrow, and having the feathers pointed, the outer feathers being much broader than the centre ones. There is but one genus and a single species in this sub-family.

THE PASSENGER PIGEONS. GENUS ECTOPISTES.

Ectopistes, Swainson, Zool. Journ. p. 362 ( 1827 ). Type, E, migratorius (Linn.).

The following is the only representative of the genus:-

I. THE AMERICAN PASSENGER PIGEON.

ECTOPISTES MIGRATORIUS.

Columba migratoria, Linn. Syst. Nat. i. p. 285 ( 1766). 
Ectopistes migratorius, B. O. U. List Brit. B. p. I40 (I883); Saunders, ed. Yarrell's Brit. B. iii. 1. 28 (1883); id. Man. Brit. B. p. 474, note (1889); Salvad. Cat. B. Brit. Mus. xxi. p. 369 ( 1893 ).

Adult Male.-General colour slaty-grey on the mantle, wingcoverts, lower back, rump, and upper tail-coverts ; scapulars brown, with black marks caused by longitudinal patches near the base of the outer web, a few of the adjacent median and greater coverts similarly marked ; bastard-wing, primary-coverts, and quills black, the primaries externally margined with whitybrown, the inner ones more broadly with white near the base of the outer web ; centre tail-feathers slaty-black, the remainder grey, with more or less white along the inner web of all but the outside feathers, which are white on the outer web and grey on the inner one; all but the centre feathers with a patch of cinnamon near the base of the inner web; head and hind-neck, sides of face, and throat slaty-blue, paler on the latter, the sides of the neck metallic reddish lilac, extending round the hindneck and on to the upper mantle, these parts being shot with coppery bronze; under surface of body, from the middle of the throat downwards, rich vinous cinnamon, paler on the breast, the lower abdomen and under tail-coverts white; sides of body and axillaries slaty-grey, the under wing-coverts darker slate colour, and those near the edge of the wing slaty-blackish; quill lining dark ashy. Total length, 16.2 inches; culmen, 0.7 ; wing, 8.45 ; tail, 7.85 ; tarsus, $\mathbf{r} \cdot 2$.

Adult Female.-In the British Museum are specimens, sexed as females, which do not differ from the males in colour. Salvadori and Ridgway, however, describe the hen birds as having a brownish head and whitish throat. According to the latter the chest and breast are greyish brown or drab, gradually changing to pale brownish-grey on the sides; the belly and under tail-coverts white. Total length, 14.5 inches; wing, 7.8 .

Young.-Browner than the adults and marked with white fringes to the feathers of the upper surface, the quills edged with light rufous. The throat and abdomen white; lower throat, fore-neck, and chest brown, with whitish fringes to the feathers. 
Range in Great Britain.-The Passenger Pigeon has been shot five times in our islands, but Mr. Saunders doubts if, on these occasions, the birds have been really wild individuals.

Range outside the British Islands. - The range given for the species in the "Check-List of North American Birds" (p. I 79) is as follows :-_ "Eastern North America, from Hudson's Bay southward and west to the Great Plains, straggling westward to Nevada and IVashington Territory."

Habits.-Dr. Brewer, in the "History of North American Birds," gives the following notes on the species :-

"Mr. Audubon states that in $18 \mathrm{I} 3$, on his way from Henderson to Louisville, in crossing the barrens near Hardensburg, he observed these birds flying to thc south-west in greater numbers than he had ever known before. He attempted to count the different flocks as they successively passed, but after counting one hundred and sixty-three in twenty-one minutes he gave it up as impracticable. As he journeyed on, their numbers seemed to increase. The air seemed filled with Pigeons, and the light of noon-day to be obscured as by an eclipse. Not a single bird alighted, as the woods were destitute of mast, and all flew so high that he failed to reach any with a rifle. He speaks of their aërial evolutions as beautiful in the extreme, especially when a Hawk pressed upon the rear of a flock. All at once, like a torrent, and with a noise like that of thunder, they rushed together into a compact mass, and darted forward in undulating lines, descending and weeping near the earth with marvellous velocity, then mounting almost perpendicularly in a vast column, wheeling and twisting so that their continued lines seemed to resemble the coils of a gigantic serpent. At times they flew so low that multitudes were destroyed, and, for many days, the entire population seemed to eat nothing else but Pigeons.

"When a flight of Pigeons discovers an abundant supply of food, sufficient to induce them to alight, they are said to pass around in circles over the place, making various evolutions, after a while passing lower over the woods, and at length alighting; then, as if suddenly alarmed, taking to flight, only to return immediately. These mancuvres are repeated with various indications of indecision in their movements, or as if 
apprehensive of unseen dangers. During these manœuvres the flapping of their many thousand wings causes a reverberation suggestive of thunder. When at last settled upon the ground, they industriously search among the fallen leaves for the acorns and the beech-mast, the rear flocks continually rising, passing over the main body, and re-alighting. These changes are so frequent that at times the whole collection appears to be in motion. A large extent of ground is thus cleared in a surprisingly short space of time, and cleared with a completeness that is described as incredible. They are usually satiated by the middle of the day, and ascend to the trees to rest and digest their food. On these occasions the Pigeons are destroyed in immense numbers, and their abundance in large extents of the country has been very sensibly reduced."

Nest.-Composed of a few dry twigs laid crosswise and built upon the branches of trees. (Brewer, t.c. p. 373.)

Egg's.-Two in number, pure white. Axis, I.4-I.6 inches; diam., I·O-I'I 6 .

THE GROUND-PIGEONS. FAMILY PERISTERIDA.

In this family of Pigeons the bill is not hooked, and the nostrils are parallel to the edges or tomia of the upper mandible. The tarsus is equal to, or longer than, the middle toe, and the number of tail-feathers varies from twelve to twenty.

THE TURTLE-DOVES. SUB-FAMILY TURTURINA.

In this Sub-family there are no long hackles on the neck, neither is there any black spot beneath the ear-coverts, as in the Zenaidina. Count Salvadori gives the following supplementary characters :-No metallic spots on the wings; tail of twelve feathers, rather broad; tarsus naked on the upper part; neck with a dark collar, more or less distinct, or with scale-like patches on the sides.

The Turtle-Doves, which includes five sub-genera-Turtur, Homopelia, Streptopelia, Spilopelia, and Stigmatopelia-are entirely confined to the Old World, over the whole of which they are distributed. 
THE TRUE TURTLE-DOVES. GENUS TURTUR. Turtur, Selby in Jardine's Nat. Libr. Pigeons, p. I69 (I835). Type, $T$. turtur (Linn.).

The characters of the genus Turtur are the same as those of the Sub-family recorded above.

\section{THE TURTLE-DOVE. TURTUR TURTUR.}

Columba turtur, Linn. Syst. Nat. i. p. 284 (I 766); Macgill. Brit. B. i. p. 29 I ( 1837 ).

Turtur vulgaris, Eyton ; Dresser, B. Eur. vii. p. 39, pl. 462 $(1876)$.

Turtur communis, Selby ; B. O. U. List Brit. B. p. I39 (I883); Saunders, ed. Yarrell's Brit. B. iii. p. 2 I ( $\delta_{3} S_{3}$; id. Man. Brit. B. p. 473 (I 889 ); Lilford, Col. Fig. Brit. B. part xxviii. (I 894).

Turtur auritus, Ray; Seebohm, Hist. Brit. B. ii. p. 4I I (I 884 ). Turtur turtur, Salvad. Cat. B. Brit. Mus. xxi. p. 396 (1893).

Adult Male-General colour above brown, with a ruddy shade, the scapulars and wing-coverts rufous, with black spearshaped centres to the feathers, less strongly indicated on the wing-coverts; the outer lesser coverts, and the median and greater series bluish-grey, the innermost ones rufous, with black centres, like the scapulars; bastard-wing and primarycoverts blackish, externally bluish-grey; quills dusky brown, with a slight ashy shade externally, the feathers narrowly fringed with whity-brown; lower back, rump, and upper tailcoverts brown, with a ruddy tinge and more or less grey, especially on the sides of the back; centre tail-feathers dusky brown, with whity-brown tips, the remainder of the feathers black with broad white ends, the outer ones also white on their outer webs; head and nape bluish-grey; on the sides of the neck a large patch of mottled feathers, black with bluishwhite margins, having a scalloped appearance; sides of face and throat pale vinous, deepening on the fore-neck and breast, and fading off towards the abdomen, which is white, the under tail-coverts being pure white; axillaries and sides of body slaty-blue, the under wing-coverts darker slate-colour; quills 
dull ashy below; bill brown; feet red; iris reddish-brown; bare skin round the eye red. Total length, II inches; culmen, 0.7 ; wing, 6.8 ; tail, 3.9 ; tarsus, $0^{\circ} 9$.

Adult Female.-Similar to the male, but with the plumage rather duller. Total length, $10^{\circ} 5$ inches; wing, 6.8 .

Young.-Browner than the adults, with broader and duller rufous edges to the scapulars and wing-coverts; quills edged and tipped with rufous. There are no dark patches on the sides of the neck, and the throat and breast are dull pale ashy, with a wash of fulvous brown on the lower throat; the flanks grey, and the rest of the lower parts white.

Range in Great Britain.-A summer visitor, arriving in May or at the end of April. It breeds throughout England up to Yorkshire, but is rare to the northward, though it is believed to have bred in Durham, Northumberland, and Cumberland, and even in the south of Scotland. It has occurred in migration as far north as the Shetlands and the Faeroe Isles. As regards its occurrence in Ireland, Mr. R. J. Ussher writes :- "It is recorded as having once nested near Downpatrick, and once at Derraquin, Kerry (Thompson). A female, with eggs in its ovary, was once shot near Avoca in Wicklow (Walters), and recently Mr. E. Williams has obtained, near Dublin, some birds so young that they seemed to have been reared in the county. As it is often observed in spring, it probably breeds more frequently than is supposed."

Range outside the British Islands.-The present species is a summer resident throughout the Western Palæarctic Region, and winters in Northern Africa as far south, at least, as Shoa. In Central Asia it extends to Yarkand, Afghanistan, and Baluchistan; but Mr. Hartert considers the Eastern birds to belong to a distinct pale race which he has called Turtur.

Habits.-Seebohm gives the following note:-The TurtleDove is very careful to conceal its nest, and breeds only in districts that afford it plenty of cover. It is very partial to dense game-coverts and plantations, and loves the more open districts, if the hedges are tall and thick. It also frequents parks and pleasure-grounds, and is commonly met with in close shrubberies. Soon after their arrival the woods and 
groves are full of their soft note, which is a rich low coor-r-r coor- $r-r$, prolonged for some time, and often modulated in different ways. In cultivated districts it is a very timid bird, and at the least alarm seeks safety amongst the trees, where, when perched, it is ever looking anxiously from side to side, as if fearful of an enemy's approach ; but it is a very easy bird to shoot when feeding in open country where it is not molested. The food of the Turtle-Dove is chiefly composed of grain and small seeds; but, doubtless, like its near allies, the Pigeons, it varies this diet with land-shells and fruit. Like the rest of the Pigeons, the Turtle-Dove drinks frequently and regularly. It is said by some writers that it only takes fresh water; but Stevenson, in his "Birds of Norfolk," notices its partiality for salt, and thinks that this is the reason why it occurs so abundantly near the coast. Other Pigeons are known to prefer brackish water to fresh.

"Like its cousins, the Pigeons, the Turtle-Dove often flies far to feed, and small parties of these birds, as well as of StockDoves, may be constantly seen in spring on the IVallachian Steppes ten miles or more from a tree or even a bush. I have shot them on these prairies as late as the 28 th of May. The flight of this bird is very powerful, and often accompanied with loud clashing together of the wings. On the ground it runs among the earth-clods with great ease, continually depressing its head and contracting its neck."

Nest.-A flat structure of twigs, varying in strength and dimensions. It is often built in evergreen trees or bushes in parks and gardens, or in a dense hedge, and generally at no great distance from the ground.

Eggs.-Two in number, creamy-white. Axis, $\mathrm{I}^{\cdot} \mathrm{I}_{-} \mathrm{I} \cdot 3$ inch ; diam., $0.85^{-1} \cdot 0$.

II. THE ORIENTAL TURTLE-DOVE. TURTUR ORIENTALIS. Columba orientalis, Lash. Ind. Orn. ii. p. 606 (I 790). Turtur orientalis, Salvad. Cat. B. Brit. Mus. xxi. p. 403 ( $\mathrm{I}_{93}$ ).

Adult Male.-Similar to T. turtur, but rather larger, with the edges to the feathers on the side of the neck bluish-grey, the 
abdomen vinous like the breast, and the under wing-coverts and the band at the end of the tail-feathers bluish-grey, instead of white; bill blackish; feet dull purplish lake. Total length, I $3^{\circ} \circ$ inches ; culmen, $0^{\circ} 7$; wing, $77^{\circ}$; tail, 4.5 ; tarsus, $I^{\circ} \circ 5$.

Adult Female.-Similar to the male, but smaller. Total length, 12 inches; wing, $6 \cdot 7$.

Range in Great Britain. - A single specimen of this eastern species of Turtle-Dove was shot near Scarborough on the 23 rd of October, 1889, and was exhibited by the late Mr. Seebohm, on behalf of Mr. James Backhouse of York, at a meeting of the Zoological Society, on the 6th of May, I 890.

Range outside the British Islands.-According to Count Salvadori, this species of Turtle-Dove is found from the base of the Himalayas to Central India, and through the Burmese countries to Formosa, Manchuria, Corea, and Japan.

Habits.-Captain Hutton states that the present species arrives at Masuri in the N.W. Himalayas, early in April, when all the woods resound with its deep-toned cooing. It does not seem to differ in any respect in habits from other Turtle-Doves. It breeds in May and June, and Mr. Hume has found nests as late as August.

Nest.-According to Mr. Hume, the bird makes a loose but rather more substantial twig nest than many of its congeners; it is placed on some horizontal branch of a large tree, usually not far from the extremity.

Eggs.-Two in number, white. Axis, $\mathbf{I} \cdot \mathbf{I}-\mathbf{I}^{\cdot} 34$ inch ; diam., $0.85-I^{\circ} \cdot 0$

\section{THE SAND-GROUSE. ORDER PTEROCLETES.*}

The Sand-Grouse hold an intermediate position between the Pigeons and the Game-Birds, not only in external appearance, but on account of their anatomical and osteological peculiari-

* In the ninth volume of this Library Mr. WV. R. Ogilvie Grant has described all the Game-Birds, including the Sand-Grouse. Il is the acknowledged authority on these Orders of birds and I have therefore merely given an epitome of the British species, founded on Mr. Grant's work above-mentioned. Much of the information in the following pages is a copy of Mr. Grant's work, for the simple reason that I have not scen how to improve upon it. 
ties. Thus Mr. Ogilvie Grant writes :- "Their general structure presents many striking Columbine characters, as in the vocal organs, pterygoid bones, and the presence of basipterygoid processes $(b p)$ in the skull (fig. I), the shoulder-girdle,
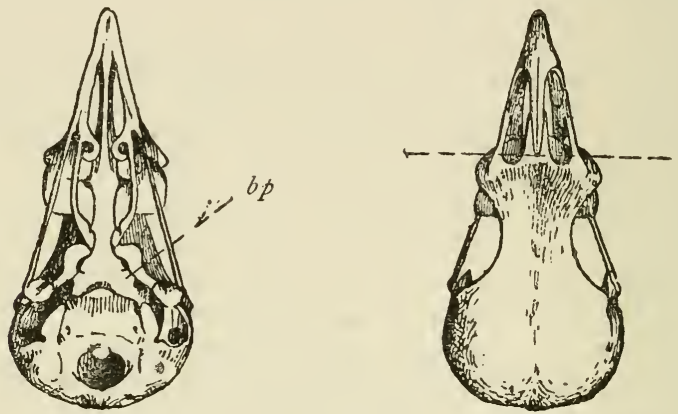

Fig. 1. -Skull of Pterocles exustus. Fig. 2. -Skull of P. exustus.

sternum, and especially the great deltoid process of the humerus, or upper-wing bone; but the digestive organs are like those of the True Game-Birds."

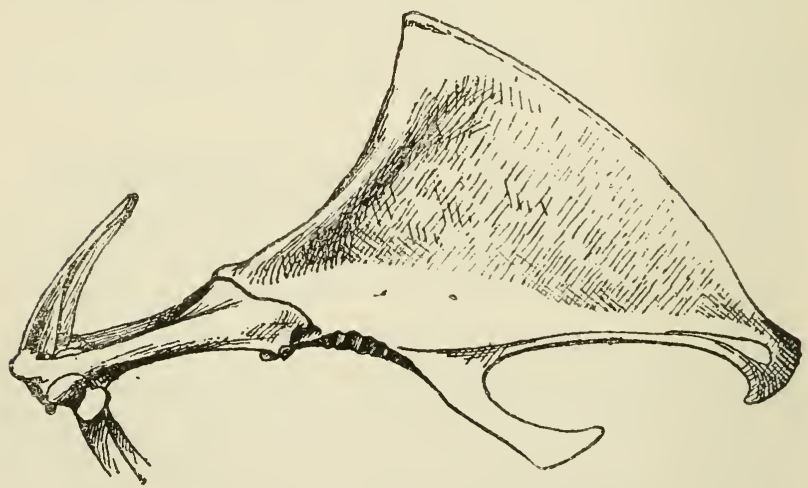

Fig. 3. - Sternum of Pterocles alchatus. 
Among other distinctive characters may be mentioned the schizorhinal nasals and the sternum, with two notches on each side of the posterior margin, the inner one being sometimes reduced to a foramen (fig. 3 ).

The bill resembles that of the True Game-Birds, but is not so strongly developed.

Three toes only occur, the hind-toe, when present, being in a rudimentary condition. The feet are very short and feathered, and the toes are either naked or thickly covered with plumes.

The wings are long and pointed.

The feathers of the body have well-developed after-shafts, like those of the True Game-Birds, but the fifth secondary flight-feather is absent.

The young are born covered with down, and are able to run soon after they are hatched.

The eggs are almost invariably three in number, smooth and glossy in texture, equally rounded at both ends, and double spotted, a set of pale purplish marks beneath the surface of the shell underlying the brown surface spots (Grant, l.c.).

\section{THE SAND-GROUSE. FAMILY PTEROCLIDA.}

The characters for the family are the same as those of the Order Pterocletes, there being but one family in the order. Only one species has occurred within our limits.

THE TIIREE-TOED SAND-GROUSE.

GENUS SYRRHAPTES.

Syrrhaptes, Illiger, Prodr. p. 243 ( $\left.1 S_{11}\right)$.

Type, S. paradoxus (Pall.).

Pallas's Sand-Grouse, which is the only species which has occurred in Great Britain, is distinguished from all the other members of the Order Pterocletes by the want of the hind-toe. The tarsus and the toes are covered with feathers.

Two species of Syrrhaptes are known, one, S. paradoxus, described below, and the other, S. tibetanus, being an inhabitant of Central Asia. 
I. PALLAS'S SAND-GROUSE. SYRRHAPTES PARADOXUS.

Tetrao paradoxa, Pall. Reis. Russ. Reichs. ii. App. p. 7 I 2 (1 773 ).

Syrrhaptes paradoxus, Dresser, B. Eur. vii. p. 75 , pl. 468 (I876) ; B. O. U. List. Brit. B. p. I40 (I883); Saunders, ed. Yarrell's Brit. B. iii. p. 31 (I883); Seebohm, Hist. Brit. B. ii. p. $4 \mathrm{I} 9$ (1884); Saunders, Man. Brit. B. p. 475 (1889); Lilford, Col. Fig. Brit. B. part xvii. (I891); Ogilvie Grant, Cat. B. Brit. Mus. xxii. p. 2 (1893); id. in Allen's Nat. Libr. ix. p. 3, pl. i. (1895).

Adult Male.-General colour above pale sandy buff; across the breast a band of white, each feather having a black subterminal cross-bar; throat rusty-red, not margined by a black line; no black spots on the side of the neck; on the abdomen a large black patch. Total length, $14^{.6}$ inches; wing, 9.1; tail, $7 \cdot 0$; tarsus, 0.8 (Grant, l.c.).

Adult Female.-Differs from the male in having the sides of the neck spotted with black; the band across the breast is wanting, and a black line bands the pale buff throat. Total length, 12.8 inches ; wing, 8.0 ; tail, 5.5 ; tarsus, 0.8 (Grant, l.c.).

Nestling.-Covered with beautifully patterned down, each plume of the body being distinct and almost scale-like in appearance, quite different from the fluffy down of young GameBirds. The general colour is pale buff, with patches of sienna and brown arranged in pairs on the sides of the head and the upper parts of the body. These patches are mostly margined and connected by irregular dotted black lines (Newton, Ibis, I 890 , p. 2 10, pl. vii.)

Range in Great Britain.-Pallas's Sand-Grouse only appears at certain intervals, when a great irruption into Western Europe takes place. Thus in 1863 , and again in 1888 , large numbers visited Britain and even bred licre. Notwithstanding the protection afforded them by intelligent land-owners, the birds vanished by degrees, and probably inigrated eastwards, back to their home in the Kirghis Steppes.

Range outside the Pritish Islands.-.The home of Pallas's Sand-Grouse is in the Kirghis Steppes, whence it extends to 
Turkestan and the region of Lake Baikal, Mongolia, and Northern China.

Habits.-The late General Prjevalsky writes:- "After their morning feed, the flocks betake themselves to some well or salt-lake to drink, apparently preferring the fresh to the salt water. At the drinking-place, as well as at the feeding-places, these birds never settle on the ground without first describing a circle, in order to assure themselves that there is no danger. On alighting they hastily drink and rise again; and, in cases where the flocks are large, the birds in front get up before those at the back have time to alight. They know their drinking-places very well, and very often go to them from distances of tens of miles, especially in the mornings between nine and ten o'clock, but after twelve at noon they seldom visit these spots." In autumn they are very gregarious, and large flocks are to be met with in the neighbourhood of their breeding-ground, unless compelled to migrate to greater distances by a heavy fall of snow.

Swinhoe says that in North China great numbers of these birds are sometimes caught after a snow-storm, when they arrive in large flocks in search of food. Having cleared the snow from a patch of ground, the natives scatter a small green bean to attract the birds and sometimes manage to catch a whole flock in their clap-nets.

Nest.-None; merely a slight hole scratched in the ground.

Eggs. - Three, sometimes four, in number. Like those of all other members of the group, the eggs are perfectly oval in shape and remarkably Rail-like in appearance, closely resembling those of the Corn-Crake (Crex crex). The groundcolour is olive or brownish-buff, spotted all over, though not very thickly, with brown and pale olive or grey, the former markings being on the surface of the shell, the latter beneath. (Cf. Grant, t.c. p. 5.)

\section{THE GAME-BIRDS. ORDER GALLIFORMES.}

The following characters of the Order are summarised by Mr. Ogilvie Grant (t. c., p. 25):- "The nasals are holorhinal (fig. 5) and true basipterygoid processes are absent, but are 
represented by sessile facets $(s f)$ situated far forward on the sphenoidal rostrum (fig. 6). The episternal process of the

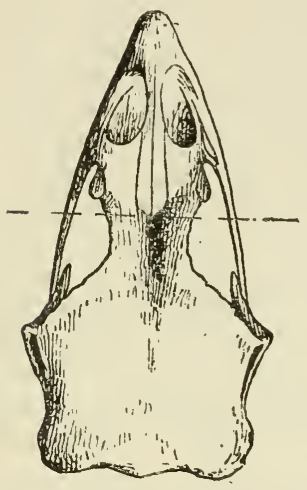

Fig. 5.-Skull of Red Grouse.

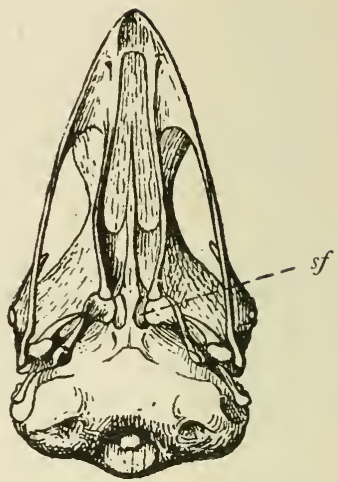

Fig. 6.-Skull of Red Grouse.

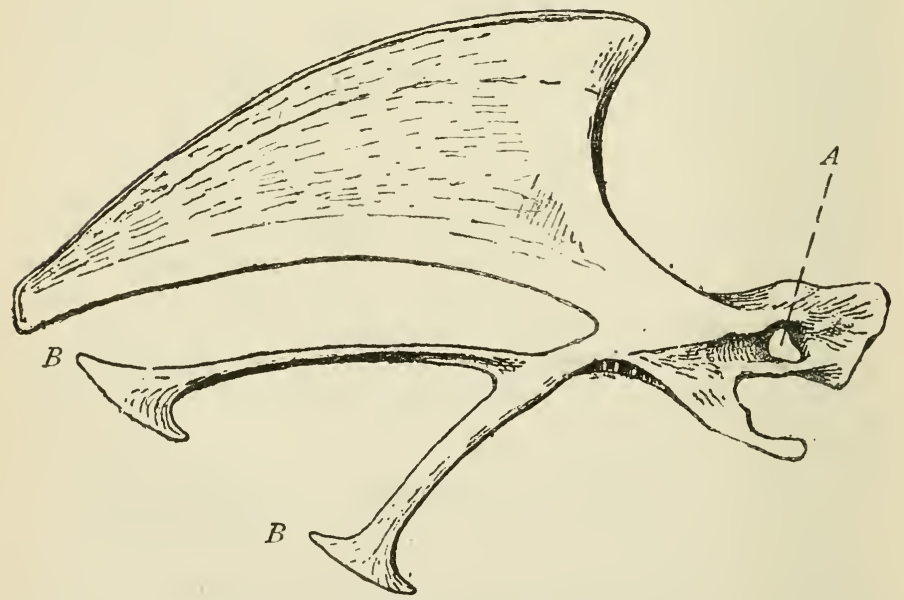

Fig. 7.-Sternum of Red Grouse. 
sternum is perforated to receive a process from the base of the coracoids (fig. 7, $A$ ), and there are two deep notches on each side of the posterior margin of the sternum (fig. $7, B$ ). The bill is short and stout, the upper mandible being arched and overhanging the lower. 'The hind-toe is always present, but varies in size and position. The feathers covering the body are provided with well-developed after-shafts. The nestlings are hatched covered with down, and able to run a few hours after their birth. The eggs, especially those of the smaller species, are often numerous, and when spotted have only a single set of surface marks, none of the pale underlying spots characteristic of the Sand-Grouse, Hemipodes, and Wading Birds, being found." (Grant, l.c.)

\section{THE GROUSE. FAMILY TETRAONIDÆ.}

The hind-toe is raised above the level of the other toes; the nostrils are covered with feathers. The legs are more or less covered with feathers, and there is no spur. The toes are also mostly covered with feathers, but are sometimes naked and pectinate, with a series of horny comb-like processes on each side. (Cf. Grant, t.c. p. 26).

THE TRUE GROUSE. GENUS LAGOPUS.

Lagopus, Briss. Orn. i. pp. I 81, 2 I 6 ( 1760$)$.

Type, L. lagopus (I inn.).

Mr. Grant characterises this genus by the dense feathering on the feet and toes. The tail is moderately long, consisting of sixteen feathers, the outer ones being nearly as long as the middle pair.

I. THE RED GROUSE. LAGOPUS SCOTICUS.

Tetrao scoticus, Lath. Ind. Orn. ii. p. 64I (1790); Seebohm, Hist. Brit. B. ii. p. 428 (I884).

Lagopus scoticus, Macgill. Brit. B. i. p. I69 (1837); Dresser, B. Eur. vii. p. I 65, pl. 479 (1873) ; B.O. U. List. Brit. B. p. I44 (I883) ; Saunders, ed. Yarrell's Brit. B. iii. p. 73 (I 883 ) : id. Man. Brit. B. p. 48I (I889); Lilford, 
Col. Fig. Brit. B. part xviii. (1891); Ogilvie Grant, Cat. B. Brit. Mus. xxii. p. 35 (1893); id. in Allen's Nat. Libr. ix. p. 27 (1895).

The Red Grouse is such a well-known bird that a detailed description is unnecessary, but the reader is referred to the excellent descriptions published by Mr. Ogilvie Grant. The following account of the variations in the plumage of this species is the result of very careful study on his part, and I cannot do better than quote it, as I find nothing to add on my own account. The figures referred to in his descriptions will be found in the volume quoted (Allen's Nat. Libr. ix. pls. ii. iii.).

Adult Male and Female.-This species may be distinguished by having the flight-feathers always blackish-brown.

Male : Total length, 15.5 inches; wing, 8.1 ; tail, 4.8 ; tarsus, $1 \% 4$.

Female: Total length, 15 inches; wing, 7.8 ; tail, 4.3 ; tarsus, I'35.

Range--Great Britain and Ireland. The only species of Game-Bird peculiar to the British Islands.

Changes of Plumage. *- "As no group of birds, as far as I am aware, goes through so many and such varied annual changes of plumage as do the members of the genus Lagopus, which includes the Red Grouse, Willow Grouse, and four species of Ptarmigan, it will be necessary to enter somewhat fully into details so as to thoroughly understand the subject.

"The Red Grouse being one of the most variable birds in existence, we must begin by saying a few words regarding individual variation. The ordinary varieties of the male may be divided into three distinct types of plumage : a red form, a black form, and a white-spotted form. The first of these, in which the general colour is rufous-chestnut (pl. ii. fig. 8) without any white spots on the breast, is mostly to be found on the low grounds of Ireland, the west coast of Scotland, and the Outer Hebrides. Typical examples of the second, or black, form (pl. ii. fig. Io) are rarely met with, and are usually found mixed with either the red or white-spotted forms, but most often with both, and specimens in mixed plumage are * Cf. Ogilvie Grant, l.c. 
those most commonly met with. The third, or white-spotted form, has the feathers of the breast and belly, and sometimes those of the head and upper-parts, tipped with white. The most typical examples of this variety are found, as a rule, on the high grounds of the north of Scotland.

"In the female, no less than five distinct types are recognisable, the red, the black, the white-spotted, the buff-spotted, and the buff-barred, forms. The first two are the rarest, the latter being extremely uncommon (pl. iii. figs. 5 and $\mathrm{r} 3$ ). The whitespotted form occurs as in the male; the buff-spotted form, which is much the commonest and most usually met with, has the feathers of the upper parts topped at the tip with whitishbuff (pl. iii. figs. 2 and 3 ) ; the fifth, or buff-barred form (pl. iii. fig. 4), is met with in the south of Ireland, and resembles in winter (autumn plumage) the ordinary female in breeding plumage, having the upper parts coarsely barred with buff and black. Very little is known of this last variety, owing to the difficulty in obtaining birds, except during the shooting season.

"The great peculiarity of the Red Grouse, and one without parallel among birds even of the genus, lies in the fact that the changes of plumage in the male and female occur at different seasons.

"The male has no distinct summer plumage, but has distinct autumn and winter plumages, and retains the latter throughout the breeding season.

"The female has a distinct summer plumage, which is complete by the end of April or beginning of May; also a distinct autumn plumage, which is retained till the following spring.

"To put it more concisely, both male and female have two distinct moults during the year, but in the male they occur in autumn and winter, and in the female in summer and autumn; the former having no distinct summer, and the latter no distinct winter plumage.

"In the Willow Grouse and Ptarmigan there are three distinct changes of plumage in summer, autumn, and winter in both male and female alike, the winter plumage being white in all.

"The Red Grouse is considered by most ornithologists merely an insular form of the Willow Grouse, and consequently one might naturally suppose that, as the British species does not 
turn white in winter, such protective plumage being unnecessary in the localities it inhabits, the winter moult has been gradually dropped. Now this is the case with the female only, and we find the male, for no apparent reason, changing his newly acquired buff and black autumn plumage for a winter one of chestnut and black. Further investigations may lead to some explanation of this strange anomaly, but at present we know of none.

"Adult Male, Autumn Plumage-After the breeding season a very complete autumn moult takes place, the quills, tail, and feathers on the feet being entirely renewed. In most examples the feathers of the upper parts are black, margined, and irregularly barred with tawny-buff, and in most cases the bars cross the feathers more or less transversely (pl. ii. fig. 4), but in some they are more or less concentric and parallel with the marginal band, giving the upper parts a scaled appearance (pl. ii. figs. 6 and 7). The feathers of the chest are rather widely barred with buff or rufous-buff and black (pl. ii. fig. II), and some of the flank-feathers are more narrowly barred with the same colours. The rest of the under parts vary according to the type to which the individual belongs, being chestnut, black, or white-spotted, or a mixture of all three. In a bird shot on the 6 th of June, the autumn moult having commenced on the upper mantle, three different sets of feathers can be seen on the back at once, belonging to the new autumn, the old winter, and the old autumn plumages, both the latter very clearly showing the result of wear and tear (pl. ii. figs. $\mathrm{I}-3$ ).

" The males at this season, no matter to what type they belong, bear a much closer resemblance to one another than they do in their winter plumage, only the under parts of the body differing conspicuously.

"The first feathers of the winter plumage begin to appear about the beginning of September.

"Adult Male, Winter-summer Plumage.-General colour above black, with finely of mottled bars of dark chestnut (pl. ii. fig. 5); head, neck, and chest (pl. ii. fig. I 2) mostly dark chestnut, finely marked with black; and the flanks mottled and barred with the same colours, the chestnut usually predominating. Generally a greater or less number of autumn 
feathers are retained, and are conspicuous among the new winter plumage. The rest of the under parts remain the same as after the autumn moult.

"The general colour of each bird varies, of course, according to the type to which it belongs, some being darker, some lighter. When once the winter moult is complete, no change whatever takes place in the plumage of the male till the following autumn moult, except that the feathers become bleached and worn at the extremities.

"Adult Female, Autumn-Winter Plumage.*-Upper parts black, with narrow irregular bars and mottlings of rufous, and a buff spot at the tip of most of the feathers (pl. iii. figs. 2 and 3 ); chest and flank-feathers narrowly and often irregularly barred with rufous and black, and usually more or less tipped with buff (pl. iii. figs. Io and I I). The rest of the under parts are dark chestnut, mottled and barred with black, or black barred with chestnut. The typical white-spotted form differs, of course, in having the feathers of the under parts widely tipped with white.

\section{"Adult Female, Summer Plumage.-}

\section{"A. Feathers of the Upper parts.}

"So far as I have been able to ascertain from examining a large number of specimens, the summer feathers of the upper parts are always attained by moult, and never by change of pattern. The summer moult of these parts is very complete, and the transformation from the autumn-winter plumage very remarkable. Every female assumes the summer plumage, and at this season all the different types closely resemble one another, but one can generally tell by the colour of the under

* The form described is the commonest or buff-spotted form of the female in autumn plumage. In typical examples of the red form the buff spots at the ends of the feathers of the upper parts are absent, and this is also the case in the much rarer black form. In the buff-barred form, from the south and west of Ireland, the terminal buff spot takes the form of a marginal bar, and the feathers are practically indistinguishable from the breeding or summer plumage. It may transpire that, in the south of Ireland, the most southerly point of this bird's range, the female retains her breeding plumage throughout the year, but this seems unlikely, and birds killed between the months of April and August are wanted to settle this point. 
parts to which form an individual belongs. In the average female in full breeding dress the upper-parts may be described as black, each feather being rather widely margined, barred, and marked with orange-buff (pl. iii. fig. I). The protection afforded by this plumage is so perfect that, when the bird is sitting on its nest among heather and dead grass, it may easily remain unobserved, though only a few yards distant.

"This plumage, however, varies much in different individuals, birds from the west of Scotland, Yorkshire, and Ireland having the orange-brown bars much brighter and wider than in the more finely mottled and darker specimens generally characteristic of the east of Scotland.

\section{"B. Feathers of the Sides and Flanks.}

"By the first week in May the summer plumage of the female Grouse is fairly complete, and many of the finely mottled rufous and black autumn flank-feathers are replaced by widely, and often irregularly, barred buff and black feathers, similar to those of the chest. It must be particularly noted that in none of the many females examined, in breeding plumage, were the whole of the autumn flank-feathers cast or changed in the summer moult, a large proportion being retained, unchanged in colour, till the next (autumn) moult. The summer flankfeathers are produced in two ways, either by a gradual rearrangement and change in the pigment of the autumn feathers (pl. iii. figs. 6-8) or by moult (pl. iii. fig. 9). In some birds the whole of the alteration in the plumage of the flanks is produced by change of pattern in the old autumn feathers, in others the change is entirely produced by moult, while sometimes both methods are employed by the same individual. In the former case, the first indication of the coming change may be observed in the beginning of November, or even earlier, when many of the flank-feathers show traces of an irregular buff stripe or spot near the terminal half of the shaft (fig. 7). As the birds only change about half their flankfeathers, these buff marks are only to be observed on such as are destined to undergo alteration of pattern, which, roughly speaking, means every second or third feather. The buff spot gradually enlarges and spreads along the shaft, then becomes constricted at intervals, and breaks up into patches, which 
gradually extend laterally towards the margins of the webs, forming wide irregular buff bands (fig. 8). Meanwhile the interspaces become black, and the rufous of autumn dies out.

"When the summer feathers are supplied by moult, they usually begin to make their appearance about the beginning of March, and even when fully grown, they may generally be recognised from those produced by change of pattern by their more regular black and buff barring (pl. iii. fig. 9). The change of pattern without a moult appears to take a long time to become complete, for we find, as already shown, that though autumn feathers, altered in this way, begin to show traces of the coming metamorphosis as early as the beginning of November, the colours are often imperfectly arranged by the end of April. When the summer feathers are supplied entirely by moult, no change whatever is visible in the autumn plumage of the flankfeathers till about the end of February, when the first new feathers begin to appear, though we have noted a single instance of one summer feather making its appearance as early as the middle of December.

"There can be no doubt that the male completes his autumn moult very much more quickly than the female does, many males being in full autumn plumage by the beginning of September. Possibly this may be accounted for by the resources of the female being more severely taxed than those of the male during the breeding season. It may very naturally be asked why some females should change their summer flank-feathers by moult, while others are enabled to arrive at the same result by going through the much less exhaustive process of redecorating their old autumn feathers, and making them serve the purpose of new breeding plumage. This is a difficult question to answer, but it seems natural to suppose that the more vigorous birds gain their summer flank-feathers by moult, while nature has enabled the weaker individuals to obtain the necessary protective nesting plumage by a more gradual and less exhaustive process.

\section{"C. Feathers of the Chest.}

"The summer change of the feathers of the fore-neck and chest in the female Red Grouse is similar to that which takes place on the sides and flanks, but is very much more complete, 
all the feathers being widely barred with black and yellowishbuff by the beginning of May (pl. iii. fig. 12).

"As will be easily understood, these being conspicuous parts of the bird when she is sitting on her eggs, it is most important for her that the protective black and buff plumage should be complete. The greater part of this change is generally produced by moult ; but, as is the case with the flank-feathers, some individuals (probably less robust females) attain the change without moulting. The same rearrangement of the pigment described in speaking of the flanks takes place in the chest-feathers, and the finely mottled and barred, rufous and black, autumn plumage becomes widely barred with black and buff."

Young Birds in July resemble the adult female in breeding plumage in their general colour, but the flank-feathers of the adult plumage begin to appear about this time. By the month of November the young are generally not to be distinguished from the adults.

Nestling.--In this and all the other species of Lagopus, the nestling is covered with fluffy yellow down, with rich brown pattern on the upper-parts.

Range.-Confined to the British Islands.

Habits. - "This species inhabits the open moors covered with heath and ling from sea-level, but is not found above the limits where these plants grow, its place being taken on the mountain tops of many parts of Scotland by the Ptarmigan. Unlike the Black Game, the Red Grouse is strictly monogamous, each male pairing with one female only, and assisting her to rear the young. The nesting season is, roughly speaking, in April and May, but varies according to locality and season, eggs being. sometimes found much earlier and as late as June, though the latter are probably second sittings, the first having been destroyed. The female in her black and buff summer garb is practically invisible when sitting on her nest, her colours harmonising perfectly with her surroundings."

As the young Grouse become strong on the wing and the season advances, the various coveys, especially if the weather is wet and stormy sonn unite their forces and go about in large 
flocks known as "packs," the males and females generally forming separate parties; and it is not uncommon to find that all the birds killed in one drive are cocks, while on another beat the reverse obtains. (Grant, l.c.).

Nest.-A slight hollow in the ground, sheltered by the longer heather and grass, and lined with moss and grass or such materials as chance to be on the spot. (Grant, l.c.).

Eggs.-Varying in number from seven to ten and sometimes more. The ground-colour is pale cream or buff, spotted and blotched all over with dark reddish-brown, which often nearly conceals the ground-colour. Average measurements, I. 75 by $1 \cdot 32$ inches. (Grant, l.c.).

II. THE PTARMIGAN. LAGOPUS MU'TUS.

Lagopus cinereus, Macgill. Brit. B. i. p. 187 (1837).

Lagopus mutus (Montin); Dresser, B. Eur. vii. p. 157, pls. 477, 478 (1874); B. O. U. List. Brit. B. p. I 44 (1883); Saunders, ed. Yarrell's Brit. B. iii. p. 83 (1883); Lilford, Col. Fig. Brit. B. part iii. (1888); Saunders, Man. Brit. B. p. 483 (1889); Grant, Cat. B. Brit. Mus. xxii. p. 44 (1893); id. in Allen's Nat. Libr. ix. p. 38 (1895). Tetrao mutus, Seebohm, Hist. Brit. B. ii. p. 424 (1884).

Adult Male and Female at all seasons. * - Outer tail-feathers black, with only the bases and tips more or less white; flight-feathers always white; bill much more slender than in the Red Grouse or Willow Grouse; wing shorter, males measuring about 7.5 inches from the bend of the wing to the end of the longest flight-feather.

Adult Male and Female, Winter plumage-General plumage and middle pair of tail-feathers white, with a black patch in front of the eye in the male, which is absent or rudimentary in the female.

Adult Male, summer Plumage.-Head, upper-parts, middle pair of tail-feathers, sides, and flanks dark brown, mottled and

* The descriptions are again taken from Mr. Ogilvie Grant's volume (l.c.). 
barred with grey and rusty; breast brownish-black, sometimes more or less barred and mottled with buff ; rest of under parts white.

Adult Female, Summer Plumage.-General colour above black, mixed with rufous-buff, most of the feathers being edged with whitish-buff ; middle pair of tail-feathers and under parts rufous-buff, barred with black.

Adult Male and Female, Autumn Plumage.-Upper parts, middle pair of tail-feathers, breast, and sides grey, finely mottled with black, and sometimes with buff; rest of under-parts white. The female may generally be distinguished by having some feathers of the faded summer plumage remaining among the grey autumn plumage.

Male : Total length, 14.5 inches ; wing, $7^{\cdot 6}$; tail, 4.6 : tarsus, $I \cdot 3$.

Female : Total length, 14 inches; wing, 7.4 ; tail, 4.1 ; tarsus $I \cdot 3$.

For the changes of plumage through which the Ptarmigan passes, the reader is referred to the most excellent account published by Mr. J. G. Millais in his "Game Birds and Shooting Sketches," quoted by Mr. Grant (t.c. p. 39).

Range in Great Britain.-Only found in the higher mountains of Scotland.

Rang outside the British Islands.-The Ptarmigan inhabits the mountains of Europe south of the Alps and the Pyrenees, east to the Ural Mountains, and probably some of the higher ranges of Central Asia.

Habits.-Mr. Ogilvie Grant gives the following account of the habits of the species :- "The home of the Ptarmigan is among the high stony table-lands and rocks above the limits of treegrowth and heaths. Like the Willow Grouse, the plumage of the male varies greatly in different localities, and the amount of white feathers retained during the summer and autumn plumages is greatly affected by the latitude which the birds inhabit, examples from the north of Norway retaining much white in the upper parts throughout the summer months. This does not apply to the females, all of which get their full summer breeding-dress, which is no doubt essential for their 
protection during the nesting season. In the same way, the mixed plumage of the males no doubt renders them less conspicuous among the patches of snow which, in the more northern latitudes, are not melted during the short summer. The general habits of the Ptarmigan resemble those of the Grouse, their monogamous habits, mode of nesting and feeding, being much the same; but the call is very different from the bec of the latter, and is more of a hoarse croak. The female is an excellent mother, taking the greatest care of her young, and boldly menacing any unexpected intruder who may come on her unawares. She flutters along the ground or runs towards her supposed enemy with drooping wings and halting gait to attract attention, while the young disappear as by magic, and vanish among the crevices of the stones. Ptarmigan depend greatly for safety on the perfect harmony of their plumage with their natural surroundings, and it is astonishing to see how they will sometimes rise all round one, almost from under one's feet, on comparatively bare ground, without any previous evidence of their presence."

Nestling, Nest, and Eggs.-Similar to those of the Red Grouse, but the eggs of the latter are rather smaller, less thickly covered with blotches, and more buff in general appearance.

THE BLACK GROUSE, GENUS LYRURUS.

Lyrurus, Swains. Faun. Bor. Amer. Birds, p. 497 (I83I).

Type, L. tetrix (Linn.).

The genus Lyrurus differs from Lagopus in having the feet feathered, but the toes are naked and pectinate on the sides. There are eighteen tail-feathers, and the outer pair are curved outwards in the male.

Only two species of Lyrurus are known, our own Black Grouse, and L. mlokosiewriczi of the Caucasus Mountains.

I. THE BLACK GROUSE. LYRURUS TETRIX.

Tetrao tetrix, Linn. Syst. Nat. i. p. 274 (1766); Macgill. Brit. B. i. p. I 45 (1 837 ); Dresser, B. Eur. vii. p. 205 , pl. 487 (1873) ; B. O. U. List. Brit. B. p r45 (r883); Saunders, 
ed. Yarrell's Brit. B. iii. p. 60 (1883); Seebohm, Hist. Brit. B. ii. p. 435 (1884) ; Lilford, Col. Fig. Brit. B. part vii. (1888); Saunders, Man. Brit. B. p. 479 (1889).

Lyrurus tetrix, Grant, Cat. B. Brit. Mus. xxii. p. 53 (1893). id. in Allen's Nat. Libr. ix. p. 45 (1895).

Adult Male.-Plumage mostly black; the under tail-coverts pure white. Total length, 23.5 inches; wing, 10.3 ; tail, 8.8 ; tarsus, I'9.

Adult Female.-Plumage mostly rufous and buff, barred with black, the black bars on the breast being much coarser than in the female of $L$. mlokosiezriczi, and the tail shorter. Total length, 17 inches; wing, 8.9 ; tail, 4.5 ; tarsus, $r \cdot 6$.

Nestling.--Covered with yellowish down, patterned with chestnut-brown on the upper parts.

Changes of Plumage. ${ }^{*}$-During the heavy autumn moult, which takes place in July and August, when the males are entirely devoid of tails and generally incapable of flying more than a few yards at most, a temporary protective plumage, like that of the female, clothes the head and neck, and the throat becomes more or less white. The object of this change is obvious, for the black head and neck of the male are con. spicuous objects among the heather and rushes, but the rufous-buff feathers, with their black bars and marks, harmonise perfectly with these surroundings and enable the defenceless birds to escape the observation of their enemies. The barred feathers of the head and neck are not cast and replaced by black till the rest of the plumage has been renewed, and the bird is once more able to fly.

The young male, unlike that of the Caucasian Black Grouse, attains the black adult plumage at the first autumn moult, and by November resembles the old male, but some of the finely mottled shoulder-feathers and inner flight-feathers of the first plumage are generally retained till the second season, and the outer tail-feathers are shorter and less beautifully curved.

Females that have become barren from age or accident commonly assume the male plumage to a greater or less ex-

* The descriptions of the plumage are copied from Mr. Ogilvie Grant's volume (l.c.). 
tent, some examples having much black in the plumage and a very well developed forked black tail, each feather being prettily edged with white. One peculiarity of these birds is the colour of the throat, which in the most fully plumaged examples is pure white.

The only time when the throat of the male is white, or partially so, is during the short period when the temporary hen-like plumage covers the head and neck. At that season the throat becomes white or thickly spotted with white. No doubt this is the source whence the pure white throat of the barren female is derived.

Range in Great Britain.-Principally found in Scotland and the North of England at the present day, but formerly distributed over England in localities suited to its habits. It is still to be found in many parts of England and Wales, and is an inhabitant of the wilder districts of the south-western counties.

Range outside the British Islands.-Europe and Northern and Central Asia, eastwards to the River Kolima, Northeastern Siberia, southwards to the Eastern Pyrenees, North Italy, Northern Caucasus, Tian Shan, and Peking, and northwards to about $69^{\circ} \mathrm{N}$. lat. (Ogilvie Grant).

Habits.-Mr. Ogilvie Grant writes :- "Pine and birch-forests are the true home of this bird, and though, when feeding, it may often be met with on the open moors or in the stubble-fields at a considerable distance from any covert, it is truly a denizen of the woods, and passes the greater part of its existence on the branches, where, unlike the Red Grouse, it is perfectly at home. Black Grouse, like other Game-Birds, are extremely partial to grain, and in some parts of Scotland, where they are still numerous, frequent the stubble-fields in enormous flocks, generally in the early morning and towards evening. They are polygamous - that is to say, one male pairs with many females, and generally towards the end of March or beginning of April the pairing season commences, when the cocks are in the habit of repairing at dawn and sunset to some particular spot to display their charms to the females and give battle to their rivals.

"The extraordinary pantomime gone through by each male as he struts round the arena, generally an open patch of ground 
worn nearly bare by constant traffic, is most entertaining to observe. With drooping wings, outspread tail, and many other curious antics, accompanied by an occasional spring into the air, he attempts to secure the goodwill of the ladies, and when two birds meet, a slight skirmish, in which a few feathers are lost, takes place. As a rule, no serious fights, such as one sees between Red Grouse, occur, merely a 'round with the gloves,' to entertain the ladies of the harem; but occasionally, when two rivals chance to meet, a furious 'set-to' may be witnessed, the fight lasting till one or both birds are thoroughly exhausted, bleeding, and torn. These strange entertainments last till the females-or ' Grey-hens,' as they are called-have laid all their eggs and commenced to sit, when the males are seen no more, the hatching of the eggs and rearing of the young being exclusively the task of the females."

Nest.-A slight hollow in the ground, scratched out and with little lining; usually well concealed.

Eggs.-Generally six to ten in number. Buff, spotted with rich brown. Average measurements, 2 inches by $I^{\circ} 4$.

THE CAPERCAILZIES. GENUS TETRAO.

Tetrao, Linn. Syst. Nat. i. p. 273 ( 7 66).

Type, T. urogallus, Linn.

The Capercailzies are the largest of the Grouse, and have eighteen tail-feathers like the Black Grouse. The tail is rounded or wedge-shaped, differing from that of the genus Lyrurus in this respect.

I. THE CAPERCAILZIE. TETRAO UROGALLUS.

Tetrao urogallus, Linn. Syst. Nat. i. p. 273 ( 1766 ); Macgill. Brit. B. i. p. 138 ( 1837 ); Dresser, B. Eur. vii. p. 223 , pl. 490 (I873); B. O. U. List Brit. B. p. I45 (I883); Saunders, ed. Yarrell's Brit. B. iii. p. 45 (I883); Seebohm, Hist. Brit. B. ii. p. 440 (1884) ; Saunders, Man. Brit. B. p. 477 (I889); Ogilvie Grant, Cat. B. Brit. Mus. xxii. p. 60 (1893); Lilford, Col. Fig. Brit. B. part xxviii. (I894); Ogilvie Grant in Allen's Nat. Libr. ix. p. 49 (1895). 
Adult Male.*-Above dark grey, shading into reddish-brown on the wings and finely mottled with black; a metallic green band across the chest, and the throat glossed with the same colour. Middle of the back not barred with black; the shoulder-feathers not tipped with white; and the breast and belly black, a few feathers in the middle being tipped with white. Total length, 35 inches ; wing, 14.6 ; tail, I 2.3 ; tarsus, $2 \cdot 8$.

Adult Female.-Middle of the back rufous and buff, strongly barred with black; breast and belly buff or whitish-buff, barred with black; general colour of the plumage darker than in $T$. uralensis, the white tips to the scapulars being narrower. Total length, 25 inches; wing, I $1^{\circ} 7$; tail, $7{ }^{\circ} 3$; tarsus, $2 \cdot I$.

Younger Males resemble the adult, but are smaller, and the white band across the tail is wanting.

Nestling.--Very similar to that of $L$. tetrix.

Range in Great Britain.-Formerly indigenous to Great Britain, the Capercailzie became extinct, and has been re-introduced. It is now found in Perthshire, Forfarshire, and the neighbouring districts.

Range outside the British Islands.-This species is an inhabitant of the pine-forests in the mountain-ranges of Europe, extending to North-eastern Turkestan, the Altai Mountains, as far east as Lake Baikal.

Habits.-The following account has been published by the late Mr. Lloyd in his well-known work, "The Game Birds and Wild Fowl of Sweden and Norway":-

"The whereabouts of the Lek-ställe, of which mention was made in the last chapter, having been ascertained, the gunner -for a sportsman he can hardly be called-proceeds to the spot, either overnight (in which case he bivouacs in its vicinity), or at a very early hour in the morning. 'He should be there,' we are told, 'by the first dawn of day, when the Woodcock begins to rôde, and the shrill notes of the Woodlark (Alauda arborea, Linn.)-hence called the Tjäder-klockan, or the Capercali-watch-are heard in the forest."

* Descriptiuns taken from Mr. Ogilvie Grant's volume (l.c.). 
"Here the man listens in profound silence until he hears the spel of the cock, then, for the most part, perched on or near to the top of a pine. Sheltering himself as much as possible behind trees and other cover, he stealthily approaches the bird; but, owing to imperfect daylight and thickness of the wood, he is often unable to see it until close upon it. So long, nowever, as the first and second notes, knäppningen and klunken, last, he must remain stationary, and, if in an exposed situation, immovable as a statue. But when the bird's third note, sisningen, commences, which, as said, continues only a very short time-and in the while the bird is all but blind and deaf-he takes three to four steps, or rather strides, in advance, when he again halts. Should all remain perfectly quiet, however, the bird almost immediately recommences its spel, and, when it once more comes to sisningen, the man, as before, moves forward several steps; and by thus alternately halting and advancing he at length arrives within gunshot of the Capercali, whose fate is then soon sealed.

"The Capercali during its spel is very watchful; and the fowler must therefore be exceedingly guarded in his movements while thus stealing on it; and at such times as the bird is heard, although not seen, he should, of all things, avoid looking about him. Want of caution on the part of the fowler in this matter has saved the lives of many Capercali. Its eye, indeed, is said to be so piercing as more readily to discover the face and hands of the man, if they be uncovered, than his person; and some, therefore, deem it advisable not only to wear gloves but to hold down the head.

"The fowler should also be careful never to advance until the sisningen has actually commenced, for an old Capercali cock that has previously started will, perhaps, when one imagines it is on the very point of beginning the last-named note, suddenly stop in its spel; and if one then advances, will most assuredly take wing. When again the man halts after sisningen, it should be in an easy position; so that, however long he may have to wait before the bird recommences its spel, it will not be needful for him to change it for another.

During the early part of the Spring, when the cock carries on his spel quite alone, he runs the greatest risk of his life; 
but when, at an after period, he is joined by the hens, they act the part of his guardian angels. On the least appearance of peril, they, to put him on his guard, utter a peculiar kind of cackle, and should not this suffice to attract his attention, one or other of them will straightways fly past the tree on which he is perched, and at times so near to him as apparently to strike him with the tip of her wing, which unmistakable hint he cannot but comprehend, and, as a consequence, moves off at once ' in the wake' of his kind monitress.

"Happily but few hens, comparatively speaking, are shot at the Lek-stïlle, partly because they are more wary than the cock, but chiefly, I take it, owing to the fowler having other and better game in view. Indeed, were a proportionate slaughter to take place amongst them, the breed, in some parts of Scandinavia, must soon become extinct. As it is, the cocks are so ruthlessly shot down during the pairing season that a large portion of hens are unable to find mates; and hence the number of barren birds (Gall-Hönor) one meets with in the forest. Were people to refrain from killing the cocks until the spring is well advanced, and pairing for the most part over, no great harm would be done, and they still might have ample amusement; for the cocks, especially the young ones, continue, as said, to spel until the middle of May, or it may be even longer.

"The number of Capercali-of cocks, I speak-that a man may thus kill at the Lek-ställe within a given time depends greatly on circumstances. If, for instance, the weather be boisterous, or there be a crust on the snow, which in more northern parts of Scandinavia often remains on the ground until late in the spring, it may happen that even the most experienced chasseur will hardly kill a single bird in a week; but under favourable circumstances, on the contrary, a good deal may be done. I, myself, have known more than one inan to shoot from five to six of these birds in the course of the morning and evening of the same day, but one or two is a more usual number. A peasant in the interior, however, who knows what he is about, and devotes much of his time to the purpose as many do, will probably kill from fifteen to twenty cocks during the spring. I was, indeed, assured by an acquaintance of mine, who resided in the heart of Wermeland 
Finn Forests, that one particular spring he shot no less than twenty-nine. This, in a country where nearly everyone carries a gun, will give some idea of the havoc that is thus annually made amongst these noble birds.

"In the northern parts of Scandinavia the Capercali is generally shot at the Lek-ställe with a small pea-rifle; but in the south the shot-gun is almost universally used for the purpose."

Nest.--Similar to that of the Black Grouse.

Eggs.-Like those of the Black Grouse, but larger. Axis, $2 \cdot 2$ inches; diam., $\mathrm{I} \cdot 6$.

\section{FAMILY PHASIANID㤅.}

\section{THE PARTRIDGES. SUB-FAMILY PERDICINÆ.}

The Partridges are distinguished from the Pheasants by their shorter tail, which is much shorter than the wing. The first quill is equal to or longer than the tenth.

THE CHUKOR PARTRIDGES. GENUS CACCABIS. Caccabis, Kaup. Natürl. Syst. p. I83 (1829). Type, C. saxatilis (W. \& M.).

1. THE RED-LEGGED PARTRIDGE. CACCABIS RUFA.

Tetrao rufa, Linn. Syst. Nat. i. p. 276 ( 1766 ).

Perdix rubra, Macgill. Brit. B. i. p. 215 (1837).

Caccabis rufa, Dresser, B. Eur. vii. p. 103, pl. 47 I, fig. i. $(18,5)$; B. O. U. List Brit. B. p. I4I (I883); Lilford, Col. Fig. Brit. B. part viii. (1888) ; Grant, Cat. B. Brit. Mus. xxii. p. I 18 (1893); id. in Allen's Nat. Libr. ix. p. 96 (I 895 ).

Perdix rufa, Saunders, ed. Yarrell's Brit. B. iii. p. I1 5 (1883); Seebohm, Hist. Brit. B. ii. p. 457 (I884); Saunders, Man. Brit. B. p. 489 (I889). 
Adult Male.-Above greyish olive-brown; feathers of the sides of the chest broadly margined with black; throat surrounded by a black band; belly bright rufous buff; flankfeathers pale grey, followed by a narrow white, and then a narrow black band, ending in a broader band of dark chestnut; outer tail-feathers dark chestnut. Total length, $13^{\circ} 6$ inches; wing, 6.2 ; tail, 3.7 ; tarsus, $1 \cdot 7$.

Adult Female.-Similar to the male. Total length, 13 inches; wing, 6.0 ; tail, 3.6 ; tarsus, $\mathrm{I} \cdot 6$.

Range in Great Britain.-Mr. Saunders writes:- "The Redlegged Partridge was successfully acclimatised in England about 1770 ; and as the result of this and subsequent introducductions it is now thoroughly established in Suffolk, Norfolk, Lincolnshire, Cambridgeshire, Essex, some of the Midlands, and on dry ground along the northern side of the Thames Valley."

Pange outside the British Islands.-An inhabitant of Southwestern Europe, ranging north to Belgium and Switzerland, and in the south to Madeira, the Azores, and Gran Canary, and in the east to South and Central Italy, also to Elba, Corsica, and the Balearic Islands (Grant). A dark form, called C. hispanica, occurs in Spain; it has "been figured in Mr. Ogilvie Grant's volume (pl. x.).

Habits.-Mr. Ogilvie Grant writes :- "This remarkably handsome species was first introduced into the south-eastern counties of Great Britain about a century ago. like the rest of its allies, it is an inveterate runner, and generally prefers to escape from approaching danger on foot, which it does with great rapidity, seldom taking to flight unless hard pressed or suddenly disturbed. When once on the wing, however, the flight is rapid and straight, and for this reason these birds afford capital sport when driven; but if shot over dogs or walked up in cover their cursorial habits are alike detestable to man and dog, for the Red-legs not only seldom rise themselves till they are at the other end of the field and probably far out of shot, but disturb and put up any coveys of Grey Partridges they may chance to pass on their course. They are very partial to hedgerows or the edges of plantations and long grass or rushes, and when 
flushed, occasionally perch on a neighbouring tree, which the Grey Partridge, so far as we are aware, never does. In the pairing season the Red-legs are very pugnacious, fighting fiercely not only with the males of their own kind, but also with those of the Grey Partridge, which, being much smaller birds, are in most cases driven from the field. Eggs of the latter species, as well as those of the Common Pheasant, are sometimes found in the nests of $C$. rufa, and are doubtless laid there by the females instead of in their own nest, an irregular habit by no means rare among Game-Birds."

Nest.- "A hollow scratched in the ground under the shelter of a hedge, tall grass, or growing crops." (Grant, l.c.)

Eggs. - "Ten to eighteen in number, and sometimes more. Pale stone-colour or buff, more or less thickly dotted and spotted, and sometimes blotched with dark reddish-brown. Average measurements, ${ }^{\circ} 55$ by $\mathrm{I}^{\circ} 2$ inch." (Grant, l.c.)

THE TRUE PARTRIDGES. GENUS PERDIX.

Perdix, Brisson, Orn. i. p. 2 I9 (I 760 ).

Type, $P$. perdix (Linn.).

The genus Perdix, of which our well-known Partridge is the type, has the feathers scarcely extending below the tibio-tarsal joint, and the tail-feathers are sixteen or eighteen in number. The first primary is intermediate in length between the seventh and eighth, and the fourth is slightly the longest. The feet are without spurs in either sex, and the plumage of both is alike or slightly different. (Cf. Grant, in Allen's Nat. Libr. ix. p. I43.)

Four species of Perdix are known, viz., P. perdix of Europe, $P$. daurica of North-Eastern Asia, $P$. hodgsonice of Thibet, and $P$. sifanica of Kansu.

I. THE COMMON PARTRIDGE. * PERDIX PERDIX. Tetrao perdix, Linn. Syst. Nat. i. p. 276 ( 1766 ).

* Mr. Ogilvie Grant's account of the difference of the plumage in the sexes is most interesting and is quoted here in extenso. 



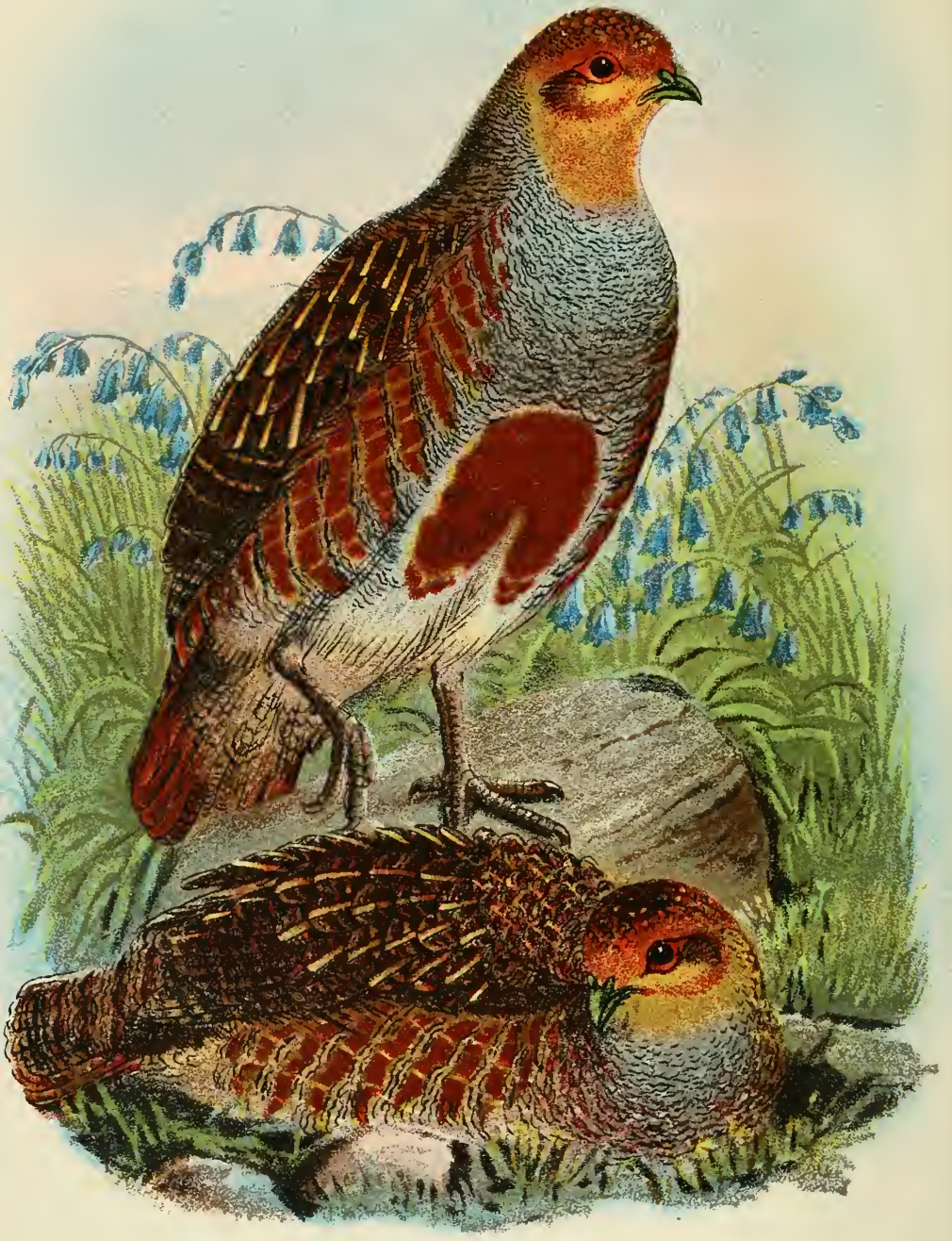

COMMON PARTRIDGE. 
Perdix cinerea, Lath.; Macgill. Brit. B. i. p. 218 (1837); Dresser, B. Eur. vii. p. I31, pl. 475 (I878); B. O. U. List. Brit. B. p. $142\left(\mathrm{I}_{8} 3\right)$ ); Saunders, ed. Yarrell's Brit. B. iii. p. I05 ( 1883 ); Seebohm, Hist. Brit. B. ii. p. $45^{2}$ (1884); Lilford, Col. Fig. Brit. B. part ix. (1888); Saunders, Man. Brit. B. p. 487 (1889).

Perdix perdix, Grant, Cat. B. Brit. Mus. xxii. p. I85 (1893); id. in Allen's Nat. Libr. ix. p. r43 (1895).

\section{(Plate CXXIII.)}

Adult Male-General colour above brownish-buff (washed with grey in birds from Northern Europe), with narrow, closeset, wavy cross-bars and lines of black; lesser and median wing-coverts and scapulars blotched on the inner web with chestnut, and with only buff shaft-stripes (fig. r). Top of the head brown, rest of the head, throat, and neck chestnut ; breast grey, finely mottled with black, below which is a large horseshoe-shaped chestnut patch; rest of under-parts whitish ; first flight-feather with extremity rounded; feet horn-grey. Total length, 12.6 inches ; wing, 6.2 ; tail, 3.5 ; tarsus, 1.7 .

Adult Female.-Easily distinguished from the male by having the ground-colour of the lesser and median wing-coverts and scapulars mostly black, with wide-set buff cross-bars, in addition to the longitudinal buff shaft-stripe down the middle of each feather (figs. 2 and 3 ); and the chestnut patch on the breast small, or sometimes absent.

Immature examples of both sexes exhibit the characteristics of the adult, but may be recognised by having the first primary flight-feather pointed at the extremity instead of being rounded, and the feet yellowish horn-colour.

The immature female has generally a well-developed chestnut horse-shoe mark on the breast.

Range.-Europe and Western and Central Asia, extending in the west to Scandinavia and the British Isles, in the east to the Barabinska Steppes and Altai Mountains, and in the south to Northern Spain and Portugal, Naples, the Caucasus, Asia Minor, and North Persia.

Mr. Ogilvie Grant writes :-_"As considerable interest attaches to the sexual differences in plumage in the Common Partridge, it may be worth while to republish here the substance of my 
articles on this subject which appeared in the 'Field' (Nov. 2I, I891; April 9, I892).

"In every text-book on ornithology which gives a description of the plumage in the male and female of the Common Par-

Fig. 2.

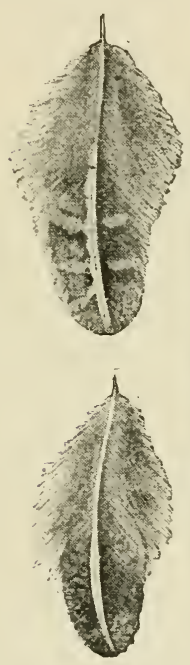

Fig. I

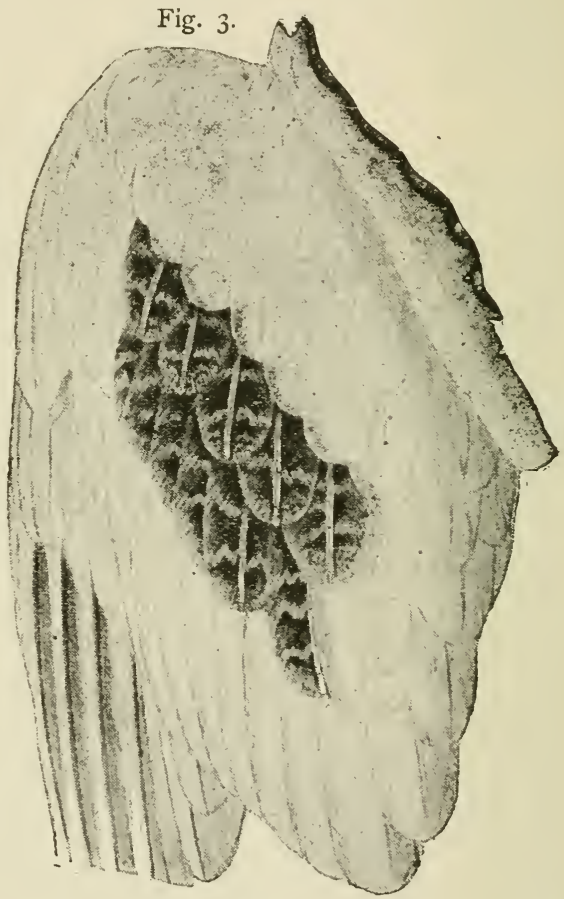

Fig. I.-Median wing-covert of male Partridge. Figs. 2 \& 3.-Median wing-coverts of female Partridge.

tridge we find that the chief difference mentioned as distinguishing the two sexes is, that the male has a large chestnut horse-shoe-shaped mark on the lower breast, while in the female this marking is reduced to a few chestnut spots, or is some. times entirely absent. This character, as we first pointed out 
in the 'Field,' is not to be depended on, for the great majority of young females-by which we mean birds of the year-have a well-developed chestnut horse-shoe, and in some, for instance birds from Leicestershire, it is quite as large and perfectly developed as in the majority of adult male birds. Young females from Norfolk and Suffolk are, however, generally exceptions to this rule, and, like the majority of old females, have merely a few chestnut spots on the middle of the lower breast, and in this part of England it is rare to meet with anything like a perfect horse-shoe in young birds of this sex, while examples may be found without a trace of chestnut, and are commonly known as birds with a white horse-shoe. As remarked above, the birds of the year, whether male or female, are easily distinguished from old birds by having the first flight-feather pointed instead of rounded at the extremity. The colour of the feet and toes is also, of course, a good character for distinguishing young birds from old ones in the earlier part of the season, but at the commencement of hard weather the yellowish-brown feet, denoting youth, having generally changed to bluish-grey, are perfectly similar to those of the adult, while the pointed first flightfeather is retained till the following autumn moult. The only reliable character for distinguishing the sexes at all ages, except in very young birds in their first plumage, is in the markings of the lesser and median wing-coverts and scapulars, the buff cross-bars in the female being an uninistakable mark, and quite sufficient to distinguish her from a male at a glance. It is now some years since we first drew attention to these rather important differences, which had hitherto been entirely overlooked, and we may now safely say that, though many people, especially sportsmen, were at first disinclined to believe in this character being a sexual difference, and tested it severely, it has, so far, never been found to fail. To convince gamekeepers of these facts is in most cases a hopeless task-that the horse-shoe mark on the breast is a certain sign of the male is 'bred in the bone,' having been handed down as gospel for generations. One Scotch keeper in particular, at a place where we have enjoyed many a pleasant day's Partridge shooting, rises before our mind, and the remembrance of this excellent and extremely obstinate soul 
always makes us smile. Often at lunch-time have we started him on the Partridge question, merely for the fun of hearing hin argue and stick to his opinion and that of his forefathers ; and his politely incredulous smile on being shown, by the help of a knife, that some particular bird with a large horse-shoe mark really was a female by dissection, had to be seen to be appreciated. But there are some people who will never allow that they are mistaken, and as long as this good man remains we may safely look forward to many a half-hour's amusement, though the dissection of numerous Partridges does not meet with our host's entire approval. It must be added that barren females are sometimes met with in more or less perfect male plumage. One barren female (by dissection) in the National Collection, has an enormous chestnut horse-shoe mark on the breast, while the wing-coverts have one web of each feather like that of the niale, and the other barred as in the ordinary female. This, and one other example, are the only two that have come under our notice, though we have examined thousands of birds, and we may safely conclude that they are by no means common."

varieties.-A curious rufous variety of the Common Partridge (see vol. ix. pl. xii.) was first described under the name of Perdix montana by Brisson,* who believed it to represent a distinct species. This is not, however, the case, as every intermediate phase of plumage between the Common Partridge and the most extreme chestnut form can be found. The finest examples of this variety have the whole head and neck dull rust-red and the remainder of the plumage dark chestnut, except the thighs and lower part of the belly, which are whitish, as well as some bars and markings on the wing-coverts and scapulars. Brisson's specimens were obtained in the mountains of Lorraine, but fine examples have also been procured in Northumberland, Cheshire, and Wiltshire in England, as well as from other localities, and there can be no doubt that this form is merely a sport of nature or accidental variety in which the chestnut colour pervades the whole plumage. Equally perfect examples of both sexes have been obtained. Grey, cream-coloured, and white examples of the Common

* Orn. i. p. 224, pl. xxi. fig. 2 (1760). 
Partridge are sometimes met with, but are by no means common, and generally prove to be birds of the year, probably because birds of peculiar plumage are generally shot down or killed by birds of prey, \&c., while still young, being more conspicuous than their neighbours (Grant, l.c.).

Nest.-A slight hollow in the ground, roughly lined with a few dry grasses, \&c., and sheltered by rough grass, growing crops, or bushes.

Eggs.-Ten to fifteen, and sometimes as many as twenty, in shape pointed ovals; uniform pale olive-brown in colour. Average measurements, $\mathrm{I}_{4} 4$ by $\mathrm{I} \cdot \mathrm{I}$ inch.

\section{THE QUAILS. GENUS COTURNIX.}

Coturnix, Bonn. Enc. Méth. Intr. pp. Ixxxviii. 2 I 6 (I 790 ). Type, C. coturnix (Linn.).

Tail composed of ten or twelve feathers, short, soft, and hidden by the upper tail-coverts; less than half the length of the wing. First primary flight-feather about equal to the third, the second being generally slightly the longest; in some instances the first three feathers are sub-equal, or the first may even be a trifle the longest. Axillary feathers long and white. Feet without spurs. Sexes different in plumas e (Grant).

\section{THF, COMMON QUAIL. * COTURNIX COTURNIX.}

Tetrao coturnix, Linn. Syst. Nat. i. p. 278 (1766).

Coturnix dactylisonans, Macgill. Brit. B. i. p. 233 (1837).

Coturnix communis, Bonn. ; Dresser, B. Eur. vii. p. I 43 , pl. 476 ( 1878 ) ; B. O. U. List. Brit. B. p. 143 (1883) ; Saunders, ed. Yarrell's Brit. B. iii. p. I23 (1883); Seebohm, Hist. Brit. B. ii. p. 462 (I884); Saunders, Man. Brit. B. p. 49 I (1889); Lilford, Col. Fig. Brit. B. part xxvii. (1893). Coturnix coturnix, Grant, Cat. B. Brit. Mus. xxii. p. 23 I (1893); id. in Allen's Nat. Libr. ix. p. I80 (1895).

Adult Male.-General colour above sandy-brown, with pale buff shaft-stripes and black bars and markings; chin and throat white, with a black anchor-shaped mark down the middle;

* The account of the plumages and habits of the Quail are taken entirely from Mr. Ogilvie Grant's volume on the Game-Birds. 
chest rufous-buff, with pale shafts ; rest of under-parts paler. Total length, 6.7 inches; wing, 4.2 ; tail, $\mathrm{I}^{\circ} 5$; tarsus, $\mathrm{I}^{\circ} \mathrm{O}$.

Adult Female.-Differs from the male in having no black band down the middle of the throat, and the chest more or less thickly spotted with brownish-black. From the female of $C$. japonica it may be readily distinguished by having the feathers on the chin and sides of the throat short and rounded.

The male described above is a typical example of C.coturnix. As considerable variation is to be found in the coloration of the chin and throat, and their black markings, it may be as well to give here the substance of the remarks I have published on this subject. The Migratory Quail* has been constantly confused with two more or less resident local forms, C. capensis, found in South Africa, \&c., and C. japonica, from Japan and China. The former is probably nothing more than a more richly coloured, rather smaller, resident local race of C. coturnix, but the latter is a perfectly distinct and easily characterised species. The migratory bird, wandering over an immensely wide range, visits the countries inhabitated by both these forms, and constantly inter-breeds with them, the result being that all sorts of intermediate forms occur. The male of C. japonica has the chin and throat dull brick-red, devoid of any black markings, and the intermediate plumages between this species and the migratory birds are most noticeable among the male hybrids. For instance, some have the dull brick-red throat of $C$. japonica, and the black, anchor-shaped mark of $C$. coturnix ; others have only the upper two-thirds of the throat dull red, and the lower third white; while, again, a third lot have, in addition, a black band down the middle of the red part ; and all kinds of intermediate stages between these three examples may be found. These hybrids are, so far as I know, generally only met with in Mongolia, China, and Japan, though there is one skin among the large series in the National Collection said to have been obtained in Bootan, N. India.

The Migratory Quail also inter-breeds freely with the chestnut-throated form ( $C$. capensis) found in S. Africa and the islands surrounding the coast, and the results are to be seen in

* Mr. Grant calls C. coturnix the Migratory Quail to distinguish it from the non-migratory species, $C$. capensis. 
the many male birds from S. Africa and Southern Europe, Sc., in which the white parts on the sides of the head and throat are more or less suffused with the bright rufous-chestnut characteristic of the resident bird.

A curious variety or semi-melanistic form of $C$. coturnix occurs in Spain, in the marshy neighbourhood of Valencia. A male in the British Museum has the general colour of the plumage black, and the female has the under parts suffused with sooty-brown.

Range-Africa, Europe, and Asia, except in the south-east portion. A summer visitor to Great Britain, some remaining in mild winters.

Habits. - The migratory habits of this species are well known to most people, but though the great majority-countless hosts of Quail, which may be numbered by millions rather than thousands-shift their quarters in September and October, on the approach of winter, and move southwards, in many places a certain number remain and spend the winter where they have bred. For instance, in the South of England and Ireland, and in the countries bordering the Mediterranean, a few remain to winter, but the bulk of the European summer visitors betake themselves by various lines of migration to South Africa, whence they return in March and April of the following spring. Enormous numbers also winter in India, crossing the Himalayas from Central Asia, while many arrive in Sind and Guzerat from the west, moving southwards from Baluchistan, Persia, and other northern latitudes.

The number of migrants varies greatly in different years, their movements being largely, if not entirely, regulated by the food supply and seasonal conditions of the countries which they visit.

One may form some idea of the vast number to be met with in some parts of India, from the following remarks by Tickell. He says :- "In such localities as have been above noticed, Quails at times abound to such a degree that shooting them is mere slaughter. Where birds get up at every step, dogs or beaters are worse than useless, and where the game is so plentiful, search after a wounded bird is seldom thought worth the trouble. It is usual to be provided with two or three 
guns, ${ }^{*}$ to be loaded, as fast as emptied, by a servant. With one gun only it would be necessary to wash out the barrels two or three times in the course of the afternoon, or at all events to wait every now and then for them to cool. A tolerably good shot will bag fifty to sixty brace in about three hours, and knock down many others that are not found. I remember one day getting into a deyra, or island formed by alluvial deposit, in the Ganges, between Patna (Bankipore) and Sonepore, which was sown almost entirely over with gram (chunna), and which literally swarmed with Quail. I do not exaggerate when I say they were like locusts in number. Every step that brushed the covert sent off a number of them, so that I had to stand every now and then like a statue and employ my arms only, and that in a stealthy manner, for the purpose of loading and firing. A furtive scratch of the head, or a wipe of the heated brow, dismissed a whole "bevy" into the next field; and, in fact, the embarras de richesse was nearly as bad as if there had been no birds at all."

Nest.-A slight hollow in the ground, with little or no lining, and sheltered by standing crops or grass, \&c.

Eggs.-Eight to twelve in number, but sometimes more are laid; creamy-white or buff, more or less boldly blotched and spotted with rich brown. Average measurements, $\mathrm{I} \cdot \mathrm{I} 5$ by 0.88 inch.

THE PHEASANTS. SUB-FAMILY PHASIANIN

This Sub-family is scarcely separable from the Perdicina; as in the genus Phasianus, the first primary is about equal to the eighth. The tail, however, in typical Pheasants is much longer than the wing, and the plumage is much more ornamental than in any Partridge.

THE TRUE PHEASANTS. GENUS JIIASIANUS.

Phasianus, Linn. Syst. Nat. i. p. 270 (I 766$)$.

Type, $P$. colchicus, Linn.

Tail composed of eighteen feathers, long and wedge-shaped, the middle pair being very much longer than the outer pair.

* He refers to the days before breech-loaders came in. 
First primary flight-feather about equal to the eighth, and considerably longer than the tenth.

The male has the sides of the head covered with naked scarlet skin ; there is no crest, but the ear-tufts are considerably lengthened, and the feet are armed with a pair of spurs (Grant).

The genus Phasianus is almost entirely Palæarctic in habitat, and contains eighteen species, the stronghold of the genus being Central Asia.

\section{THE COMMON PHEASANT.* PHASIANUS COLCHICUS.}

Phasianus colchicus, Linn. Syst. Nat. i. p. 27 I ( I 766 ); Macgill Brit. B. i. p. II4 (I837); Dresser, B. Eur. vii. p. 85, pl. 469 (I879) ; B. O. U. List Brit. B. p. I4I (I883); Saunders, ed. Yarrell's Brit. B. iii. p. 9I (I883); Seebohm, Hist. Brit. B. ii. p. 445 (I 884); Saunders, Man. Brit. B. p. 485 (1889); Grant, Cat. B. Brit. Mus. xxii. p. 320 (I893); Lilford, Col. Fig. Brit. B. part xxxiii. (I896).

Adult Male.--Crown of the head bronze-green; rest of the head and neck dark green, shading into purple on the sides and front of the neck. Feathers of the mantle, chest, breast, and flanks fiery orange, the former narrowly margined with purplish-green, the latter widely edged with rich purple; those of the upper back and scapulars mottled in the middle with black and buff, margined by consecutive bands of buff, black, and orange-red, and tipped with purplish-lake. Lower back, rump, and upper tail-coverts red maroon, glossed with purplishlake or oily green, according to the way the skin is held. Most of the wing-coverts sandy-brown; middle of breast and sides of belly dark purplish-green ; middle of belly and rest of under parts dark brown mixed with rufous. Tail-feathers olive down the middle, with narrow, wide-set, black bars, and widely edged on each side with rufous, glossed with purplishlake. Total length, 37.5 inches; wing, I0.1; tail, $2 \mathrm{I}^{\circ} \mathrm{2}$; tarsus, $2 \cdot 8$.

Adult Female.-General colour sandy-brown, barred with black; back and sides of the neck tinged with pinkish and

The account of this species is again copied from Mr. Ogilvie Grant's volume (Allen's Nat. Libr. xii. p. 9). 
with metallic purple or green margins; feathers of the mantle and sides of the breast and flanks chestnut, with black centres and pinkish-grey margins ; an elongated patch of white blacktipped feathers below the eyes; quills more coarsely barred and mottled with buff than in the male; tail-feathers reddish-brown down the middle, shading into sandy-olive on the sides and with wide irregular triple bars of black, buff, and black. Total length, 24.5 inches; wing, 8.6 ; tail, I I.5; tarsus, 2.4 .

Range.-The Common Pheasant has been introduced in most parts of Europe, with the exception of Spain and Portugal, and the higher latitudes of Scandinavia and Russia. For this reason it is difficult, if not impossible, to state accurately the limits of its true home. It appears, however, to be found in a wild state in Southern Turkey, Greece, and Asia Minor as far east as Transcaucasia, and it extends northwards to the Volga. On the Island of Corsica it is also met with in a wild state, and may have been imported at some remote period; but if it is really indigenous there, its range must formerly have extended much farther west than the counties mentioned above.

There is no record, as far as we know, of its importation to the British Islands, but it is mentioned in the bills-of-fare of the last Saxon king.

Habits.- The favourite home of the Pheasant is thick covert, woods with plenty of undergrowth, in the immediate neighbourhood of cultivated land, where in the morning and evening the birds can come out to feed. Oak, hazel, and fir plantations scattered over large parks are much resorted to, for the birds seldom stray far from the shelter of the trees, and retire on the slightest approach of danger, being decidedly shy and retiring in their habits.

Most of our readers are well acquainted with the Common Pheasant in a semi-domesticated state, when it is undoubtedly polygamous, one male pairing with many females, but there seems to be good reason for believing that this habit has been acquired; for, in a really wild state, all the evidence, though it is certainly somewhat scanty, tends to show that this, as well as the other species of Phasianus, is monogamous, the cock bird remaining with the female during the period of incubation, 
and taking part in the duties of protecting and rearing the young. In this as in other countries where Pheasants are reared for sport, the greater number of birds killed are cocks, and hence, in the following spring, there is generally a preponderance of females, which may account for the polygamous habits of introduced birds. The males are remarkably quarrelsome in the pairing season, fighting fiercely with one another for the different females, the more powerful birds appropriating the lion's share for their harem. When the females have laid their full complement of eggs, the male troubles his head no more about them, leaving them to undertake all the cares of rearing their family unaided. They cannot be called good mothers, for, unlike the majority of game-birds, on the approach of danger, they seek safety in flight, leaving the young to escape and hide themselves as best they can. This habit is often extremely disastrous to the brood, especially when the chicks are very small, for, on her return, the mother is apparently perfectly satisfied with finding one or two of her scattered young, and the remainder are consequently left to perish. For this reason gamekeepers are naturally anxious that the coverts, where "wild birds" are breeding, should not be disturbed during the nesting-season, and it is hardly surprising that they should treat trespassers with scant courtesy. The majority of birds shot annually in the large preserves in this country and in Europe are, of course, reared from eggs placed under domestic hens, who make excellent mothers to their foster-children. On leaving her nest in the morning and evening in search of food, the hen Pheasant is always careful to cover her eggs with dead leaves, and she generally quits and returns to her nest on the wing, thus avoiding as far as possible the danger of being tracked by her enemies.

The crow of the male resembles the syllables or-ork, which are often repeated several times in succession, and may be exactly imitated by opening the mouth and drawing the breath in sharply to the back of the throat. This call is generally to be heard in the morning and evening, especially about sunset, when the birds are going to roost, but during the pairing season it may be heard at all times of the day, and is also given vent to when they are flushed or suddenly startled by the report of a gun or a clap of thunder. 
There can be no doubt that if the Pheasant were not artificially reared and annually turned down in this country, it would soon cease to exist, for, in hard winters especially, the birds left for stock are largely dependent on artificial feeding. The chief food consists of grain, seeds, berries, and young shoots, varied with insects and grubs, wireworms being a favourite morsel.

Pure-bred examples of $P$. colchicus are now rarely to be met with in England, the great majority of birds being hybrids with the Chinese Ring-necked Pheasant ( $P$. torquatus), which was subsequently introduced.

Like the rest of its kind, the Pheasant, though it roosts and often perches on trees, is essentially a ground bird, and a tremendous runner; the old cocks, having learnt wisdom from past experience, frequently refuse to rise at the net and face the guns so anxiously waiting to salute them, and may be seen running back among the beaters as fast as their legs can carry them. The whir made in rising is loud and startling, but when once well on the wing, the Pheasant's flight is extremely swift, being performed by rapid and incessant beats of the rounded wing, and when coming high, down wind, the pace at which a good "rocketer" can travel is almost incredible.

During the nesting-season the hen Pheasant has numerous enemies to contend with, the most formidable being the prowling Fox, who seizes her as she sits on her nest, and the Rooks and Crows, both Hooded and Carrion, who steal and suck her eggs. A curious instance of the enormous amount of damage done by Crows came under my notice in May, I893.

With a friend, I was passing through a Scotch fir plantation forming part cf a large estate in the north of Scotland, where thousands of Pheasants are annually reared and turned down. The plantation ran along about a hundred feet above the rocky sea-coast, and as we advanced along the slippery path, we found several sucked pheasant's eggs, evidently the work of Crows, nor had we gone far before we came suddenly upon a whole family of Hooded rascals, five young and two old birds. In the course of about a quarter of a mile, we counted over a hundred empty shells which had evidently bcen carried to the path and there devoured. How many more might have been discovered had we searched it is impossible to say, but we saw 
ample evidence of the wholesale destruction which a family of Crows is capable of committing among Pheasants' eggs. Within two miles of this spot, to his shame be it said, stood a keeper's house, where a thousand young birds were being reared. 'This worthy informed us that the great heat and drought then prevalent was decimating his broods of young Pheasants, who were dying in scores from a disease which attacks the eyes, and from which few recover. He volunteered the information that he had not been over to the belt of fir wood "for this two months," as there was nothing there to take him so far! A little more attention to the destruction of Hooded Crows in April might have saved a hundred or two of strong wild-bred birds for the sport in the fall of the year.

Female Pheasants that have become barren either from age or through disease of the ovary, generally assume the plumage of the cock to a greater or less extent, and we have known a number of instances in which the male plumage had been so perfectly donned, that it was only by the smaller size, blunt spurs, and much shorter tail, that the true sex of the individual could be ascertained. Last year I examined a hen pheasant in perfectly normal plumage, but with a well-developed sharp spur on each leg; this bird, on dissection, was found to have been shot in the left ovary, a No. 2 or 3 shot being there imbedded, which had destroyed the organ, and given rise to an ugly tumorous growth. The wound was evidently an old standing one, but in this instance the plumage had remained normal.

The Common Pheasant not only crosses with other species of its own kind, but hybrids are occasionally produced between it and the Black Game, Domestic Fowl, and Guinea Fowl, while instances are on record of hybrids between Pheasant and Capercailzie.

Albinos and piebald birds are by no means an uncommon occurrence among our semi-domesticated birds, but no doubt much rarer among really wild individuals.

Nest.-A mere hollow in the ground, roughly lined with dead leaves, and carefully hidclen from view by dead fern, brambles, or coarse grass or other herbage. 
Eggs. - Vary in number from eight to twelve, but a score or more are sometimes found in one nest, probably the produce of more than one female ; they are broad oval, slightly pointed at the smaller end, generally brown, or olive-brown in colour, more rarely bluish-green, uniform in tint, and with rather a smooth polished shell. Average measurements, I.8 by I*4 inch.

Note. - The Andalucian Hemipode was included in the British List many years ago. Two specimens are said to have been obtained in Oxfordshire, and a third in Yorkshire. "No one," says Mr. Saunders, "who knows how sedentary and local this species is, will believe it to be a genuine visitor."

The synonymy is as follows :-

THE ANDALUCIAN HEMIPODE. TURNIX SYLVATICA.

Tetrao sylvaticus, Desfont. Mem. Acad. Sci. Paris, p. 500 ( 1789 ).

Turnix sylvaticus, Dresser, B. Eur, vii. p. 249, pl. 494 (I876); B. O. U. List Brit. B. p. I46 (I 883 ); Saunders, ed. Yarrell's Brit. B. iii. p. I3I (I883); id. Man. Brit. B. p. 492, note (I899); Grant, Cat. B. Brit. Mus. xxii. p. 537 (1893) ; id. in Allen's Nat. Libr. xii. p. 270 (IS96). 


\section{APPENDIX. \\ ADDENDA TO VOL. I.}

THe following alterations and additions have become necessary since the publication of the earlicr volumes of the present work.

Page 30.

\section{GENUS CHLORIS.}

The name Chloris having been preoccupied in Botany, the name of Ligurinus of Kaup must be employed for the Greenfinch.

Page 3I, line 6 from top. Read:-

THE GREENFINCH. LIGURINUS CHLORIS.

Page 48. Before "The Sparrows," insert :-

VI. COUES' REDPOLL. CANNABINA EXILIPES.

Egiothus exilipes, Coues, Proc. Philad. Acad. 1861, p. 385.

Acanthis exilipes, Sharpe, Cat. B. Brit. Mus. xii. p. 254 (1888). Linota hornemanni (nec. Holboell), Lilford, Col. Fig. Brit. B. part xxx. (1895).

Adult.-Very similar to the Mealy Redpole, but distinguished by its purer colour, and by having the rump pure white, with a rosy tinge, not streaked as in the Mealy Redpole. Bill, orange-yellow; the culmen and tip of the genys blackish; feet blackish-brown; iris dark brown. Total length, 5 inches; culmen, 0.4 ; wing, 3.0 ; tail, 2.3 ; tarsus, 0.55 .

The changes of plumage are similar to those undergone by the Mealy Redpoll.

Range in Great Britain.-Mr. Cordeaux has recorded a specimen of this white-rumped Redpoll from the Humber district, and two specimens are in Dr. Bendelack Hewetson's collection from Easington in Yorkshire, where they were obtained in October, 
1 $88_{3}$, and October, I 893 . One of these has been figured by Lord Lilford in his beautiful work on British Birds. I have also seen a specimen caught near Tring, in the Hon. Walter Rothschild's collection. There can be little doubt that the species occurs more frequently in Great Britain than is supposed, but is confounded with the Mealy Redpoll.

Range outside the British Islands. - This species has an extensive range, occurring from Northern Scandinavia across Siberia, and throughout Arctic America.

VII. GREENLAND REDPOLL. CANNABINA HORNEMANNI.

Linota hornemanni, Holboell, Naturl. Tidskr. iv. p. 395 (I843).

Acanthis hornemanni, Sharpe, Cat. B. Brit. Mus. xii. p. 257 (1888).

Adult Male.-Similar to Coues' Redpoll, but much larger. Total length, 5.3 inches; culmen, $0^{\circ} 4$; wing, 3.4 ; tail, 2.5 ; tarsus, 0.65 .

Adult Female. -A little smaller than the male. Wing, $3^{\cdot 2}$ inches.

Range in Great Britain.-A specimen of this large white-rumped Redpoll is recorded by the late John Hancock as having been obtained near Whitburn, in Durham, in April, I 855.

Range outside the British Islands.-The home of this species is in Eastern North America, Greenland, and Iceland.

Page 6r. Insert :-

II. THE GREATER BULlfiNCH. PYRRHULA PYRRHULA. Loxia pyrrhula, Linn. Syst. Nat. i. p. 300 ( 7766 ). Pyrrhula major, Brehm; Dresser, B. Eur. iv. p. 97, pl. 198 (1876).

Pyrrhula pyrrhula, Sharpe, Cat. B. Brit. Mus. xii. p. 446 (I885).

Adults. - Similar to $P$. europoca, but much larger, and the colours purer, especially the red colour of the breast. Total length, 6 inches; culmen, 0.5 ; wing, 2.7 ; tail, 2.6 ; tarsus, 0.7 .

Range in Great Britain.-Two specimens of the large Bullfinch were exhibited by Colonel Irby at a mecting of the 
Zoological Society on the 19th of November, 1895. They were shot on the Yorkshire coast about the Ist of November, 1893, and had been mounted by local bird-stuffers as Common Bullfinches. A third specimen has been recorded by Mr. $\mathrm{J}$. H. Gurney as having been obtained on the Caistor denes in Norfolk.

Range outside the British Islands.-Replaces $P$. europoca in Scandinavia, and from Poland eastwards throughout Siberia.

Habits. - Exactly like those of its smaller western representative. The eggs are slightly larger than those of $P$. europoea.

Page 189. Insert :-

THE SUB-ALPINE WARBLER. SYLVIA SUB-ALPINA. Sylvia sub-alpina, Temm. Man. d'Orn. i. p. 2 I 4 (1820, ex Bonelli, MSS.) ; Dresser, B. Eur. ii. p. 389 , pl. 59 (I 875 ).

Adult Male.-Slaty-grey above; wings brown, with pale edges to the coverts, the secondaries more broadly margined; tail brown, the three or four outside feathers with more or less white; chin, throat, and breast chestnut, shading off into paler chestnut on the flanks; the centre of the abdomen and under tail-coverts whitish ; under wing-coverts pale grey, with darker centres; axillaries pale vinous grey; a narrow white line along the sides of the head separating the chestnut of the lower surface from the grey of the upper; bill dark horn-colour, the lower mandible light yellowish at the base ; feet dusky brown ; iris brown; eyelid reddish. Total length, 4.6 inches; culmen, 0.45 ; wing, 2.3 ; tail, 2.1 ; tarsus, 0.7 .

Adult Female.-Browner than the male above, and not so ashy-grey. The chestnut of the under parts replaced by buffywhite, with a vinous tinge on the sides of the breast. The birds of the year are buffy-brown on the breast and flanks, the male being a little greyer than the female.

Characters. - This little Warbler is allied to the Whitethroats, but is smaller than any of them, the wing being less than 2.5 inches in length, while the colour of the legs and feet is brown. It is distinguished from all the small Warblers of the Whitethroat group by its chestnut chin and breast. 
Range in Great Britain.-A specimen of a supposed "Dartford Warbler," was procured in St. Kilda on the I $3^{\text {th }}$ of June, I 894 , by Mr. J. S. Elliott, who sent it to me for identification, and I was not a little surprised to find that it was an example of the present species.

Range outside the British Islands. - Inhabits the countries of the Mediterranean, probably as far east as Persia. Winters in Senegambia, and in North-eastern Africa.

Habit.-Mr. John Whitehead, who observed this species in Corsica, says that it is plentiful in that island, arriving about the middle of April. The first nest was taken on the 6th of May. He writes :- "This little warbler spends nearly all its time in the thick scrub, sometimes mounting high into the air, and uttering a short but pretty song, then diving back into the dense bush, its whereabouts being only discovered by a short chattering note."

Nest and Eggs. - The same observer describes these as follows: "The nest is often frail, about $1 \frac{1}{2}$ inch deep and $2 \frac{1}{4}$ inches in diameter. It is composed of dry stalks, often with a good many dead thistle-leaves, and lined with fine dry grass, sometimes with long horse-hairs. 'The eggs, four in number, are of a pale yellowish or greenish-white, speckled all over, but especially at the larger end, with light brown and slate blue."

Page 204. Add :-

THE GREENISH WILLOW-WARBLER.

PHYLLOSCOPUS VIRIDANUS.

Phylloscopus viridanus, Blyth, J. A. S. Beng. xii. p. 967 (1843); Seebohm, Cat. B. Brit. Mus. v. p. 44 (1881): Dresser, B. Eur. Suppl. p. 87 (1895); Caton Haigh, Zool. 1896, p. 446.

Adult Male.-Similar to $P$. trochilus, but rather greener above and not so yellow below, and distinguished by the wing-bar, formed by the yellowish-white tips to the greater coverts. Dull olive-green above, lighter on the rump; a yellowish-white eyestripe, well-defined, and reaching to the nape; ear-coverts 
greenish yellow; under surface of body pale greenish-yellow ; the under wing-coverts and axillaries pale yellow; "bill brown above, brownish-yellow below; legs and feet pale olivaceous grey; iris dark brown" (E. A. Butler). Total length, 4.75 inches ; culmen, 0.5 ; wing, 2.2 ; tail, 1.7 ; tarsus $0^{\circ} 7$.

Range in Great Britain.-A specimen of this Indian species was shot by Mr. G. H. Caton Haigh at North Cotes, on the Lincolnshire coast, on the $5^{\text {th }}$ of September, 1896 . Mr. Caton Haigh observes :-_"The weather prevailing at the time of its appearance was such as usually resuits in a great immigration of small birds-the wind backing to the East on the night of the $3 \mathrm{rd}$, and blowing a fresh breeze from that quarter on the $4^{\text {th }}$ and 5 th, with heavy rain commencing to fall on the afternoon of the $4^{\text {th }}$, and lasting without intermission for twenty-four hours."

Range outside the British Islands.-Mr. Gätke records three specimens from Heligoland. The home of this species is in Central Asia, as it nests in the Altai Mountains, and in Turkestan, as well as in the Himalayas. Its eastern breedingrange extends to the Ural Mountains and North-Eastern Russia. In winter it is spread over the Indian peninsula to Ceylon.

Habits.-An excellent account of this species is given by Mr. Dresser in his "Birds of Europe," from which we learn that it frequents mixed groves and woods ; and, according to Severtzoff, it is to be met with among bushes and the tall steppe-grass. Dr. Scully noticed it amongst the tamarisk and willow bushes, and remarks that it seemed very restless, continually flitting from spray to spray. Both Blyth and Dr. Scully state that its voice is weak, and the former describes the note as tiss-yip, tiss$y$ ip, frequently uttered. Sabanaeff, however, says that the voice of this bird consists of so loud and so strong a trill that it can scarcely be recognised as the song of a Leaf-Warbler, and its call-note, which is a short and shrill psi-psi, closely resembles that of the Yellow Wagtail." (Cf. Dresser, B. Eur. Suppl. p. 90).

Nest.-One found by Mr. W. E. Brooks in Krshmir, was domed, and placed on a steep bank-side of a ravine full of 
small birch trees, at an elevation of about I I, 000 feet. It did not contain eggs.

Eggs. - Unknown.

Page 2I4. Add :-

PALLAS'S WILLOW-WARBLER.

PHYLLOSCOPUS PROREGULUS.

Motacilla proregulus, Pall. Zoogr. Russo.-Asiat. i. p. 499 (I 8 I I). Phylloscopus proregulus, Seebohm, Cat. B. Brit. Mus. v. p. 7 I (188I); Dresser, B. Eur. Suppl. p. 74. pl. 650, fig. 2 (1895); Southwell, Zool. 1896, p. 8 ; Gurney, Zool. p. I 35 (1897).

Adult Male.-Similar to $P$. superciliosus, but easily distinguished by the yellow rump, in strong contrast to the greenish back. Like P. superciliosus, it has a couple of yellow wing-bars, as well as a light yellowish streak on the crown; " upper mandible dark-brown, the lower one orange nearly to the tip ; legs brown ; feet yellowish." Total length, 4.5 inches; culmen, 0.45 ; wing, 2.3 ; tail, 1.65 ; tarsus, 0.8 .

Adult Female.-Similar to the male. Total length, 3.6 inches ; wing, I' 9 .

Seebohm says that the winter plumage is scarcely distinguishable from the summer plumage, but the autumn livery is more brilliant than that of spring. In summer, the yellow of the mesial line on the crown, eye-stripes, wing-bars, and rump, becomes paler by abrasion, the pale tips to the quills disappear, and the broad edges to the innermost secondaries become narrow. Otherwise, he says, the changes from spring plumage are very slight.

Range in Great Britain.-A specimen of this Willow-Warbler was shot at Cley, in Norfolk, on the 3ist of October, I896, by Mr. E. Ramm.

Range outside the British Islands.-In Heligoland this species is believed by Gätke to have occurred at least twice. Its home is in Eastern Siberia and the Himalaya Mountains, and it visits the neighbourhood of Orenburg in autumn, and winters in Tenasserim and in Southern China.

Habits.-The present species is described as having a very powerful note. Mr. Styan describes it as a "loud Canary-like 
hreeet." Dr. Dybowski says that its note is melodious and powerful, and its song varied and sweet, and so loud that it rings through the forest, and is astonishing as coming from so small a bird.

Pallas's Willow-IVarbler is chiefly an inhabitant of the pine woods, and makes it nest on the branches of the smaller pines and moss-covered cedars, near the stem. In Kashmir, Captain Cock found the nest placed on the outer end of the branch of a fir tree, from six to forty feet elevation, and sometimes on a small sapling pine where the junction of the bough with the stem takes place.

Nest.- "The nest," says Captain Cock, "is partially domed, the outer portion consisting of moss and lichen, so arranged as to harmonise with the bough on which it is placed, and lined with feathers and thin birch-bark strips, never with hair."

Eggs.-Described by the above-named observer as being five in number, pure white, richly marked with dark brownish-red, particularly at the larger end, forming there a fine zone on most of the eggs, and intermingled with these spots, and especially on the zone, are some spots and blotches of deep purple-grey. Axis, $0.53-0.55$ inch; diam., $0.43^{-0.44}$.

\section{ADDENDA TO VOL. II.}

Page 42 .

Range of the KING-EIDER :- -

Mr. A. Trevor-Battye has pointed out to me that, by a upsus calami, I have included Spitsbergen as one of its winter habitats. He says :- "As a fact this Duck has been many times recorded in the summer in Spitsbergen, while in the winter it obviously cannot be there, nor could it be recorded if it were."

Page $\mathrm{i} 6 \mathrm{I}$, line 6 from bottom :-

With regard to the statement of the "Son of the Marshes," that "when the young are alarmed, they scatter out," the most interesting point in the nesting habits of E. hiaticola is that the parent bird itself, if suddenly disturbed, scatters the young ones with its feet, no doubt for purposes of better concealment; for the young, when so scattered, instantly squat down 
close among the stones, and are then practically invisible. A reference to this has been given by MIr. Trevor-Battye in his ornithological appendix to "Ice-bound on Kolguev," where he gives a careful description of the same tactics as pursued by the Red-necked Phalarope (Phalaropus hypoboreus).

\section{ADDENDA TO VOL. III.}

Page 63 :--

THE AMERICAN LAUGHING GULL. LARUS ATRICILLA.

Larus atricilla, Linn. Syst. Nat. i. p. 225 ( 1766 ) ; Saunders, Man. Brit. B. p. 646, note (1889); id. Cat. B. Brit. Mus. xxv. p. 194 (1896).

(Plate CXXIV.)

Adult.-Similar to $L$. ridibundus, but distinguished by its black head, dark slate-grey mantle, and its black outer primaries. Total length, I $6^{\circ} 5$ inches; wing, $13^{\circ} \circ$.

Range.-North America, migrating south to Guiana, Brazil, and Northern Peru.

This species was figured in Jardine's "Naturalist's Library," and I have thought it advisable to republish the figure. Cne specimen is said to have been procured at Winchilsea, but this is disallowed by Mr. Saunders, who says that there is no authentic record for the species in England or any part of Europe.

\section{Page 182.}

COLYMBUS ADAMSI.

During a recent visit to Manchester, I found a young bird of this species in the very interesting collection of Mr. Bulkeley Allen at Altrincham. The specimen was shot at Achaglachgach, Loch Fyne, by a keeper named Ebenezer Burgess, late in the autumn of 1893 .

\section{ADDENDUM TO PRESENT VOLUME.}

Page 25.5, line 8 from bottom. Read:- "Turtur arenicola." 


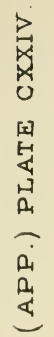

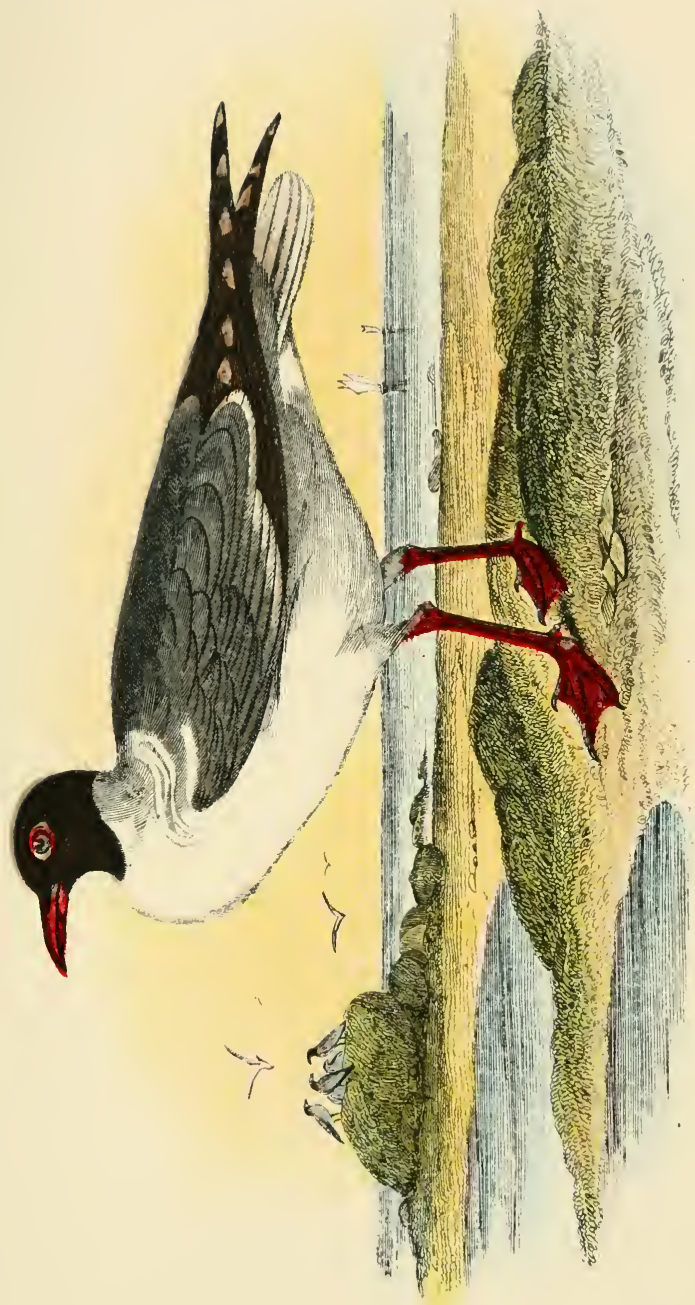

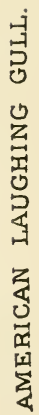





\section{ALPHABETICAL INDEX.}

Acanthis exilipes, 297 hornemanni, 298

adamsi, Colymbus, ISo, 182, 304

Aviothus exilipes, 297

albipennis, Podicipes, 209

Alca, 106

alle, 127

arctica, 130

bruennichi, 120

grylle, 123

impennis, III

torda, 106

troile, II 4,120

alchatus, Pterocles, $25^{8}$

Alle, 127

alle, 127

alle, Alca, 127

Alle, 127

Mergulus, I 27

American Laughing Gull, 304

Passenger Pigeon, 250

anæstheta, Sterna, 29

Andalucian Hemipode, 296

anglica, Gelocbelidon, II Sterna, I I

anglorum, Puffinus, I 63

Anous, 37

stolidus, 37

antarctica, Megalestris, 89

aquaticus, Rallus, 216

Arctic Tern, 21

arctica, Alca, I30

Fratercula, I 30

Mormon, I30

Sterna, 2 I

arcticus, Colymbus, 18j, 187

arenicola, Turtur, 255

argentatus, Larus, 70

arra, Uria, 121

atra, Fulica, $23 \mathrm{~S}$

atricilla, Larus, 304
Auk, Great, I II

Little, 127

auritus, Colymbus, $20 \mathrm{I}$

Dytes, 201

Podiceps, I93, 20I, 204

Podicipes, 201

Turtur, 254

bailloni, Crex, 232

Porzana, 232

Baillon's Crake, 232

Black Guillemot, I 23

headed Gull, 59

necked Grebe, 204

Shearwaters, 175

Tern, 3

Tern, White-winged, 9

throated Diver, 185

Bonaparte's Gull, 56

bonapartii, Gavia, 56

brevipes, Estrelata, 173

Procellaria, 173

brevirostris, Rissa, 84

Bridled Guillemot, I 19

bruennichi, Alca, I 20

Lomvia, I 20

Uria, 120

Briinnich's Guillemot, 120

buffoni, Stercorarius, IOI

Buffon's Skua, Ior

Bullfinch, Greater, 299

bulweri, Bulweria, 175

Procellaria, 175

Thalassidroma, 175

Bulweria, I60, 175

bulweri, 175

columbina, 175

Bulwer's Petrel, I75

Caccabis hispanica, $2 \mathrm{SI}$ rufa, 280 
cæruleus, Porphyrio, 238

californica, Uria, I 5

Cannabina exilipes, 297

hornemanni, 298

cantiaca, Sterna, 27

canus, Larus, $73, \mathrm{~S}_{3}$

Cape Fulmar, 158

capense, Daption, I $5 S$

capensis, Coturnix, 288

Daption, 158

Podicipes, 209

Procellaria, 158

Capercailzie, 276

capistrata, Gavia, 59

Capped Petrel, I72

Carolina Crake, 230

carolina, Crex, 230

Porzana, 230

Rallus, 230

carolinensis, Podiceps, 193

casiotis, Columba, 243

caspia, Hydroprogne, 14

Sterna, I4

Sylochelidon, I4

Caspian Tern, I 4

caspicus, Podiceps, 193

catarrhactes, Larus, 90

Lestris, 90

Megalestris, 89, 90

Stercorarius, 90

cayanus, Podiceps, 193

Cepphus grylle, 123 mandti, I 25

Cetosparactes eburneus, 8I chilensis, Megalestris, 89

Chloris, 297

chloris, Ligurinus, 297

chloropus, Fulica, 234

Gallinula, 234, 235, 236

cinerea, Perdix, 282

cinereus, Lagopus, 27 I

colchicus, Phasianus, 29I, 294

Columba, 24I

casiotis, 243

livia, 247

migratorius, 250

œnas, 244

orientalis, 256

palumbus, 24 I
Columba turtur, 254

columbina, Bulweria, 175

Colymbus, i 78

adainsi, I80, I \&2, 304

arcticus, 185,187

auritus, 201

cristatus, 194

fluviatiiis, 207

glacialis, I7 $8, I_{3}, I 8_{4}$

g:iseigena, 198

grylle, 123

podicipes, 213

septent ionaiis, I 87,189

troile, I I 4

Common Coot, 238

Guillemot, I I 4

Gull, 73

Partridge, 282

Pheasant, 29I

Quail, 286

Tern, 17

communis, Coturnix, 287

Turtur, 254

Coot, Common, 238

cornutus, Podiceps, 193, 201

Coturnix, 287

capensis, 288

communis, 287

coturnix, 287

dactylisonans, 287

japonica, 288

coturnix, Coturnix, $2 S_{7}$

Tetran, 287

Coues' Redpoll, 297

Crake, Baillon's, 232

Carolina, 230

Little, 223

Spotted, 226

crepidatus, Lestris, 97

Stercorarius, 97, 99

Crex, 220

bailloni, 222

carolina, 230

crex, 220

parva, 224

porzana, 226

pratensis, 220

pusilla, 223

crex, Crex, 220 
crex, Rallus, 220

cristata, Lophethyia, 19.4, 199

cristatus, Colynibus, 194

Pudiceps, 193, 194

Podicipes, 194

cryptoleucura, Cym chorea, I 43

Uceanodrom ?, 143

Cymochorea, cryptoleucura, 143 leucorrhoa, I 40

dactylisonans, Coturnix, $2 S 7$

Duption, 152, 157 capense, 158

capensis, $15^{8}$

daurica, Perdix, 282

Diver, Black-throated, i $\delta_{5}$

Great Northern, $17 S$

Red-throated, I 87

White-billed, i 82

dominicus, Podiceps, 193

Podicipes, 209

dougalli, Sterna, 23

Dove, Oriental Turile, 256

Rock, 247

Stock, 244

Turtle, 254

Dove-like Fulmars, 17 I

Dusky Shearwatcr, I68

Dytes, 193, 201 auritus, 201

Eared Grebes, 204

eburnea, l'agophila, $\delta_{1}$

eburneus, Citoparactes, 8I

$$
\text { Larus, SI }
$$

Ectopistes, 250 migratorius, 250

Eider, Kirg 304

europxa, I'yrrhula, 299

europxus, Sylbcocyclus, 207

exilipes, Acanthis, 297

Egiothus, 297

Cannabina, 297

exustus, Pterocles, 258

Flat-clawed S'orm-Petre!'s, I4t

fluviatilis, Colymbus, 207

Pudiceps, 207

Podicipes, 207 fluviatilis, St:rna, I7

Tachybaptes, 207

Fork-tailed Gulls, 4I

Petrel, 140

Fratercula, 130

arctica, I30

glacialı, 132

frontata, Gallisula, 235

Fulica atra, $23 \mathrm{~s}$ chloropus, 237

fuliginosa, Sterı, 31,32

Fulmar, 153 Cape, 158

Fuluars, Love-like, I 7

Pied, 157

Fulmarus, 152

glacialis, 153

fuscus, Larus, 66

Gabianus, $4 \mathrm{~S}$ pacificus, $4 \mathrm{~S}$

galeata, Gallinu!a, 236

Gallinula, 234

chloropus, $234,235,236$

frontata, 236

galeata, 2,6

pyrrhorhoa, 2,6

tenebrosa, 236

Gallinules, Purple, 237

Game-Birds, 26 I

Garrodia nereis, Its

Gavia bonapartii, 56

capistrata, 59

ininuta, 49

rilibunda, 59

sabin'i, 41

Gelochelidon, I I

anglica, I1

Giant Terns, I 3

glacialis, Colymbus, I78, IS 3 , IS4

Fratercula, I 30

Fulmarus, 153

I'rocellaria, 153

Glaucous Gull, 70

gravis, Procellaria, 160

Puffinus, 160

Great Auk, II I

Black-backed Gull, 63

Black-headed Gull, 5I 
Great Crested Grebe, 194

Northern Diver, 178

Shearwater, I6o

Skua, 90

Greater Bullfinch, 298

Grebe, Black-necked, 204

Great Crested, 194

Psed-billed, 2 I 3

Red-necked, 198

Slavonian, 201

Grebes, Eared, 204

Horned, 201

Little, 207

Thick-billed, 2 I 3

Tippeted, 192

Greenfinch, 297

Greenish Willow-Warbler, 300

Greenland Redpoll, 298

Grey Petrel, White-thr، ated, 173

Grey Storm-Petrels, I49

grisea, Procellaria, I69

griseigena, Colymbus, I9S

Lophrthyia, 195, 198, 199

Podiceps, 193, 198

Podicipes, 198

griseus, Puffinus, 169

Ground Pigeons, 253

Grouse, Red, 262, 263

Sand, 257,259

grylle, Alca, 123

Cepphus, 123

Colymbus, 123

Uria, 123

Guillemot, Black, 123

Eridled, I I9

Briinnich's, 120

Common, I 14

gularis, Podicipts, 209

Lull, American Laughing, 304

Black-headed, 59

Lonaparte's, 56

Common, 73

Glaucous, 76

Great Black-backed, 63

Great Black-headed, 5 I

Herring, 70

Iceland, 79

Ivory, $8_{1}$

Kittiwake, $8_{+}$
Gull, Lesser Black-backed, 66

Little, 49

Mediterranean Black-headed, 54

Sabine's, 41

Gull-billed Tern, I I

Gulls, Forked-tailed, 4I

IVedge-tailed, 45

hrsitata, Estrelata, I 72, I74

Haliplana, 3I

hebridicus, Podiceps, 193

Hemipode, Andalucian, 295

Herring-Gull, 70

hirundo, Sterna, I7, 2 I

hispanica, Caccabis, 28I

hodgsoniæ, Perdix, 282

holboelli, Lophæthyia, $2 c 0$

Homopelia, 253

Horned Grebes, 201

hornemanni, Acanthis, 298

Cannabina, 298

Linota, 297, 298

hybrida, Hydrochelidon, 4, 6 Sterna, 6

Hydrochelidon, 3

hybrida, 4,6

leucopareia, 6

leucoptera, $4,7,9$

nigra, $3,4,7,8$, Iо

surinamensis, 3

Hydroprogne, I3

caspia, It

hyperboreus, Larus, 76

Phalaropus, 304

Iceland Gull, 79

ichthyaëtus, Larus, $5 \mathbf{I}$

impennis, Alca, II I

Plautus, I I I

indicus, Kallus, $2 \mathbf{I}$

intermedia, Porzana, 232

intermedius, Rallus, 232

Ivory Gull, 8 I

japonica, Coturnix, $2 S S$

King-Eider, 304

Kittıwake Gull, 84

kuhli, Puffinus, I6 I 
Lagopus, 263

cinereus, $27 \mathrm{I}$

mutus, $27 \mathrm{I}$

scoticus, 263

lagopus, Tetrao, $27 \mathrm{I}$

Land-Rail, 220

Larus, $4 \mathrm{~S}$

argentatus, 70

atricilla, 304

canus, 73,83

catarrhactes, 90

eburneus, 8 I

fuscus, 66

hyberboreus, 76

ichthyaëtus, 5 I

leucopterus, 79

marinus, $6_{3}$

melanocephalus, 54

minutus, 49

parasiticus, IOr

philadelphia, 55,56

ridibundus, 55, 59

roseus, 45

rossii, 45

sabinii, 4 I

tridactylus, 84

Laughing Gull, American, 304

leachi, Yrocellaria, 140

Thalassidroma, I 40

Lesser Blacked-backed Gull, 66

Lestris catarrhactes, 90

crepidatus, 97

parasiticus, 101

pomarina, 93

richardsoni, 97

leucopareia, IIydrochelidon, 6

Leucophous, 4 S scoresbyii, 48

leucoptera, Hydrochelidon, 4, 7, 9 Sterna, 9

leucopterus, Larus, 79

leucorrhoa, Cymochorea, 140

Oceanodroma, 140

Procellaria, I40

Thalassidroma, I 40

Levantine Shearwater, 167

Ligurinus, 297

chloris, 297

Linota hornemanni, 297, 298
Little Auk, 127

Crake, 223

Grebe, 207

Gull, 49

livia, Columba, 247

Lomvia bruennichi, 120 troile, II 4

Long-legged Storm-Petrels, I 45

Lophrthyia, 192, 193

cristata, 194, 199

griseigena, 195, 19\$, 199

holboelli, 200

Loxia pyrrhula, 298

ludovicianus, Podiceps, 193

lunulata, Sterna, 3 I

Lyrurus, 273

mlokosiewiczi, 274

tetrix, 273, 274

maccormickii, Megalestris, $\delta 9$

macdougalli, Sterna, 24

macrura, Sterna, $2 \mathbf{I}$

Madeira Storm-Petrel, I 40

Majaqueus, 160

major, Puffinus, 160

mandti, Cepphus, 125

Manx Shearwater, 163

marina, Pelagodroma, 149

Procellaria, 149

marinus, Larus, 63

maruetta, Porzana, 2.26

Mediterranean Black-headed Gull, 54

Megalestris, 89

antarctica, 89

catarrhactes, 89,90

chilensis, $S 9$

maccormickii, 89

Megalopterus stolidus, 37

melanocephalus, Larus, $5+$

Mergulus alle, I 27

migratorius, Columba, 250

Ectopistes, 250

minor, Podiceps, 193, 207

minuta, Gavia, 49

Sterna, 34

minutus, Larus, 49

mlokosiewiczi, Lyrurus, 274 
montana, Perdix, 286

Moor-hen, 234

Mormon arctica, I 30

Motacilla proregulus, 302

mutus, Lagopus, 271

Tetrao, 27 I

nere:s, Garrodia, 148

nigra, Hydrochelidon, 3, 4, 7, 8, 10

Sterna, 3

nigricollis, Podiceps, 193, 204

Podicipes, 204

Proctopus, 204

Noddy Tern, 37

obscura, Procellaria, I68

obscurus, Podiceps, 193

Puffinus, 168

oceanica, Procellaria, 145

oceanicus, Oceanites, 145

Oceanites, I 45

oceanicus, 145

wilsoni, I45

Oceanodroma, 140

cryptoleucura, 143

leucorrhoa, 140

cenas, Columba, 244

Qistrelata, 160, I 7 I

brevipes, 173

hresitata, 172,174

torquata, 173

Oriental Turtle-Doves, $25^{6}$

orientalis, Columba, 256

Turtur, 256

Ossifraga, 152

pacificus, Gabianus, $4 S$

Pagophila, 48, 8I

eburnea, 8 I

Pallas's Sand. Grouse, 260

Willow-Warbler, 302

palumbus, Columba, 24I

paradoxa, Tetrao, 260

paradoxus, Syrrhaptes, 259, 260

parasitica, Lestris, IOI

parasiticus, Larus, IOI

Lestris, IOI

Stercorarius, 99, IOI
Partridge, Common, $2 S_{2}$

Red-legged, 280

parva, Crex, 224

Porzana, 223

Zapornia, 223, 224

parvus, Rallus, 223

Passenger Pigeons, 250

pelagica, Procellaria, I 37

Thalassidroma, 137

Pelagodroma, 149

marina, 149

Perdix, 282

cinerea, $2 \mathrm{~S}_{3}$

daurica, 282

hodgsoniæ, $2 \mathrm{~S}_{2}$

montana, 286

perdix, $2 S_{2}$

rubra, 280

rufa, 280

sifanica, 282

perdix, Perdix, $2 S_{2}$

Tetrao, 282

Petrel, Bulwcr's, I75

Capped, I 72

Fork-\{ailed, I40

Storm, 137

White-throated Grey, 173

Wilson's, 145

Phalaropus hyperboreus, 304

Phasianus, 200

colchicus, 29I, 294

torquatus, 294

Pheasant, Common, 29I

philadelphia, Larus, 55,56 Sterna, 56

philippensis, Porlicipes, 209

I'hylloscopus proregulus, 302 superciliosus, 302

trochilus, 301

viridanus, 300

Pied-billed Grebe, 213

Pied Fulmars, 157

Pigeon, American Passenger, 250 Wood, 24 I

Pigeons, 240

Ground, 253

Passenger, 250

Pointed-tailed, 250

Plautus, IIO 
Plautus impennis, I I I

Podrethyia, 193

Podiceps, 193 auritus, 193, 201, 204 carolinensis, 193

caspicus, 193

cayanus, 193

curnutus, 193, 201

cristatus, I93, 194

doninicus, 193

fluviatilis, 207

griseigena, 193, 198

hebridicus, 193

ludovicianus, I93

ninor, 193, 207

nigricollis, 193, 204

obscurus, 193

rubricollis, 193, 198

thomensis, 193

podiceps, Podilymbus, 213

Podicipes, 207

albipennis, 209

auritus, 20 I

capensis, 209

cristatus, 194

dominicus, 209

fluviatilis, 207

griseigena, 198

gularis, 209

nigricollis, 204

philippensis, 209

tricolor, 209

podicipes, Colymbus, $2 I_{3}$

Podilymbus, $2 \mathbf{I}_{3}$

Podilymbus, 193

podiceps, 213

podicipes, $2 \mathrm{I} 3$

Pointed-tailed I'igenns, 250

pollicaris, Rissa, 84

pomarina, Lestris, 93

pomarinus, Stercorarius, 93

Pomatorhine Skua, 93

pomatorhinus, Stercorarius=, 93, 39

P'orphyrio, 237

crulueus, 238

porphyrio, Porphyrio, 237, $23 \mathrm{~S}$

Porzana, 226

bailloni, 232

czrolina, 230
Porzana intermedia, 232

maruetta, 226

parva, 223

porzana, 226

pusilla, 234

porzana, Crex, 226

Purzana, 226

Rallus, 226

pratensis, Crex, 220

Priocella, I60

Prion, 152

Procellaria, 137

brevipes, 173

bulweri, 175

capersis, $15^{8}$

glacialis, I 53

gravis, 160

grisea, 169

leachi, 140

leucorrhoa, 140

marina, 149

obscura, IS6

oceanica, 145

pelagica, 137

puffinus, I 63

yelkouan, 167

Proctopus, 193

nigricollis, 204

proregulus, Motacilla, 302

Phylloscopus, 302

Ptarmigan, 27I

Pterocles alchatus, 258

exustus, 258

Pterocletes, 257

Puffin, I 30

Puffinus, 160

anglo!um, 163

graviz, 160

griseus, 169

kuhli, 16 I

major, 160

obscurus, I68

puffinus, 163,167

yelkouanus, 167

puffinus, Procellaria, 163

Puffinus, 163,167

Purple Gallinules, 237

pusilla, Crex, 223

Porzana, 234 
pyrrhorhoa, Gallinula, 236

Pyrrhula europæa, 299

pyrrhula, 298

pyrrhula, Loxia, 298

Pyrrhula, 298

Quail, Common, 287

Rail, Land, 220

Rallus, 216

aquaticus, 2 I 6

carolina, 230

cr $\in \mathrm{x}, 220$

indicus, 218

intermedius, 232

parvus, 223

porzana, 226

Razor-bill, Ic 6

Red Grouse, 262, 263 legged Partridge, 280 necked Grebe, 198

Redpoll, Coues', 297

Greenland, 298

Red-throated Diver, I 87

Rhodostethia, 45

rosea, 45

rossi, 45

richardsoni, Lestris, 97

Stercorarius, 97

Richardson's Skua, 97

ridibunda, Gavia, 59

ridibundus, Larus, 55, 59

ringvia, Uria, II 9

Rissa, 49,84

brevirostris, 84

pollicaris, 84

tridactyla, 84

Rock-Dove, 247

rosea, Rhodostethia, 45

Roseate Tern, 23

roseus, Larus, 45

rossi, Rhodostethia, 45

rossii, Larus, 45

Rotche, 127

rubra, Perdix, 2So

rubricollis, Podiceps, 193, 198

rufa, Caccabis, 280

Perdix, 280

Tetrao, 280
Sabine's Gull, 4I

sabinii, Gavia, 4I

Larus, $4 \mathrm{I}$

Xema, 4I

Sand-Grouse, 257, 259

Pallas's, 260

Three-toed, 258

Sandwich Tern, 27

saundersi, Sterna, 36

scoresbyii, Leucophæus, 48

scoticus, Lagopus, 263

Tetrao, 263, 264

septentrionalis, Colymbus, $1 \$_{7}, \mathbf{I} \$ 9$

Shearwater, Dusky, I68

Great, 160

Levantine, 167

Manx, I63

Sooty, 169

sifanica, Perdix, $2 \mathrm{~S}_{2}$

Skua, Buffon's, IOI

Great, 90

Pomatorhine, 93

Richardson's, 97

Slavonian Grebe, 20 I

Smaller Sooty Tern, 29

Sooty Shearwater, 169

Tern, 32

Spilopelia, 253

Spotted Crake, 226

Stercorarius, 89, 93

buffoni, IOI

catarrhactes, 90

crepidatus, 97, 99

parasiticus, 99, IOI

pomarinus, 94

pomatorhinus, 93, 99

richardsoni, 97

Sterna, I7

anæstheta, 29

anglica, I I

arctica, 2 I

santiaca, 27

caspia, 14

dougalli, 23

fluviatilis, 17

fuliginosa, $3 \mathbf{I}, 32$

hirundo, 17, 21

hybrida, 6

leucoptera, 9 
Sterna lunulata, 3 I

macdougalli, 24

macrura, 2 I

minuta, 34

nigra, 3

philadelphia, 56

saundersi, 36

stolida, 37

Sternula, 36

Stigmatopelia, 253

Stock-Dove, 244

stolida, Sterna, 37

stolidus, Anous, 37

Megalopterus, 37

Storm-Petrel, I 37

Madeira, I43

White-bellied, I49

Storm-Petrels, Flat-clawed, I 44

Grey, I 49

Long-legged, I 45

Streptopelia, 253

sub-alpina, Sylvia, 299

Sub-Alpine IVarbler, 299

superciliosus, Phylloscopus, $3 \mathrm{O} 2$

surinamensis, Hydrocheliclon, 3

Sylbeocyclus europreus, 207

Sylochelidon caspia, I4

sylvatica, Tetrao, 296

Turnix, 296

sylvaticus, Turnix, 296

Sylvia sub-alpina, 299

Syrrhaptes, 258

paradoxus, 259,260

tibetanus, 259

Tachybaptes fluviatilis, 207

tenebrosa, Gallinula, 236

Tern, Arctic, 2 I

Black, 3

Caspian, I 4

Common, 17

Gull-billed, I I

Noddy, 37

Roseate, 23

Sanüwich, 27

Snaller Sooty, 29

Sooty, 32

Whiskered, 6

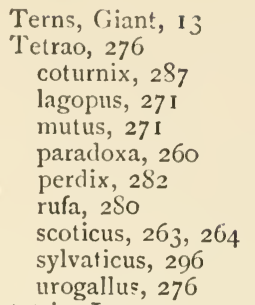

tetrix, Lyruru:, 273, 274

Thala isidroma bulweri, 175

leacbi, I 40

leucorrhoa, I 40

pelagica, I37

Thalassaca, I6o

Thick-billed Ǵrebes, 2 I 3

Three-toed Sand-('rrouse, $25^{8}$

thomensis, Podicep3, 193

tibetanus, Syrrhaptes, 259

Tippeted Grebes, I92

torda, Alca, Io6

torda, Utamania, I06

torquata, Eistrelata, I 73

torquatus, Phasianue, 294

tricolor, Podicipes, 209

tridactyla, Rissa, 84

tridactylus, Larus, 84

trochilus, Phylloscopus, 301

troile, Alca, II4, I2O

Colymbus, I I 4

Lomvia, I I 4

Uria, I I 4

Turnix sylva!ica, 296

sylvaticus, 296

Turile-Dove, 254

Turtle-Doves, Oriental, 256

Turtur, 254

arenicola, 304

auritus, 254

communis, 254

orientalis, 256

turtur, 254

vulgaris, 254

turtur, Columba, 254

Turtur, 254

Uria, II 4 
Uria arra, 121

bruennichi, I 20

californica, Ii 5

grylle, 123

ringvia, 119

troile, I I 4

Urinator, 192

urogallus, Tetrao, 276

Utamania torda, 106

viridanus, Phylloscopus, 300

vulgaris, Turtur, $25 \frac{4}{4}$

Warbler, Greenish Willow, 300

Pallas's Willow, 302

Sub-Alpine, 299

Water-Rail, 216

Wedge-tailed Gulls, 45
Whiskered Tern, 6

White-bellied Storm-PetreI, I49

- billed Diver, 182

-throated Grey Petrel, I 73

-winged Black Tern, 9

Willow-Warbler, Greenish, 300

Pallas's, 302

wilsoni, Oceanites, 145

Wilson's Petrel, I 45

Wood-Pigeon, $24 \mathrm{I}$

Xema, 41

sabinii, 4 I

yelkouan, Puffinus, 167

yelkouanus, Puffinus, 167

Zapornia, 223

parva, 223, 224 



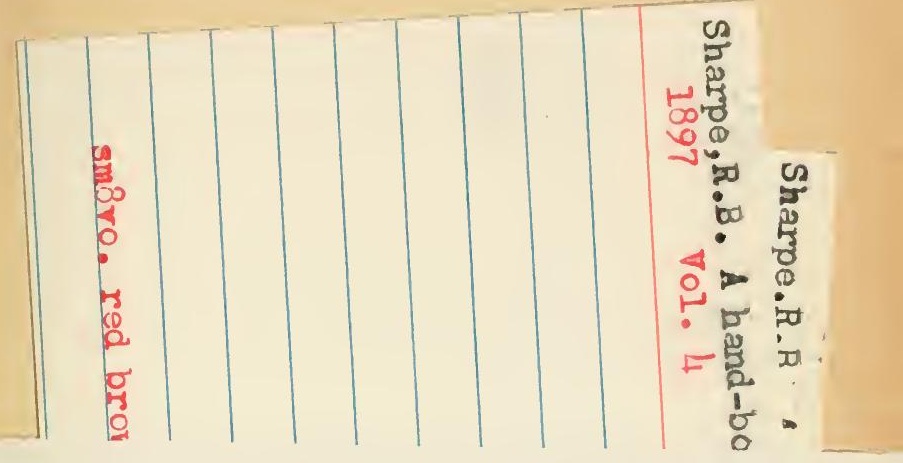


